\author{
Universidade de São Paulo \\ Faculdade de Filosofia, Letras e Ciências Humanas \\ Departamento de Antropologia \\ Programa de Pós-Graduação em Antropologia Social
}

Ana Flávia Pulsini Louzada Bádue

\title{
A nebulosa do decrescimento. \\ Um estudo sobre as contradições das novas formas de fazer política
}




\section{Ana Flávia Pulsini Louzada Bádue}

\section{A nebulosa do decrescimento. Um estudo sobre as contradições das novas formas de fazer política}

Dissertação apresentada ao Programa de PósGraduação em Antropologia Social da Faculdade de Filosofia, Letras e Ciências Humanas da Universidade de São Paulo, sob a orientação da Profa. Dra. Ana Claudia Duarte Rocha Marques, como parte dos requisitos para a obtenção do título de Mestre em Antropologia Social. 
Nome: Ana Flávia Pulsini Louzada Bádue

Título: A nebulosa do Decrescimento. Um estudo sobre as contradições das novas formas de fazer política

Dissertação apresentada ao Programa de PósGraduação em Antropologia Social da Faculdade de Filosofia, Letras e Ciências Humanas da Universidade de São Paulo, sob a orientação da Profa. Dra. Ana Claudia Duarte Rocha Marques, como parte dos requisitos para a obtenção do título de Mestre em Antropologia Social.

Aprovada em:

Banca Examinadora

Prof. Dr.:

Instituição:

Julgamento:

Assinatura:

Prof. Dr.:

Instituição:

Julgamento:

Assinatura:

Prof. Dr.:

Instituição:

Julgamento:

Assinatura: 
A meu avô, que me ensinou a gostar de história.

Ao Danilo. 


\section{Agradecimentos}

Agradeço, primeiramente, àquelas e àqueles que deram corpo a esta pesquisa: militantes e ativistas do decrescimento que me receberam em suas casas, em seus locais de trabalho, em suas reuniões, ações e manifestações. Agradeço pela disposição em me mostrar que o decrescimento era muito mais do que um conjunto de ideias, e que para saber do que se tratava, era preciso circular muito. Especialmente a Lucie Supiot, Nicolas Lechopier e Guillaume Gamblin, que me ofereceram muitas das condições necessárias para essa circulação. Agradeço também a(os) integrantes do grupo Decrescimento Brasil pelas trocas, debate e diálogos.

À professora Ana Claudia Duarte Rocha Marques, que aceitou orientar um trabalho cujo tema sempre foi tão nebuloso. Seu apoio, suas indicações e sobretudo a liberdade que sempre me concedeu foram fundamentais para deslindar o caos que insistia em se colocar diante de nós.

À professora Isabel Loureiro, pelas ricas contribuições na banca de qualificação. A suas sugestões foram de extrema importância, inspirando grande parte desse trabalho.

Ao professor Renato Sztutman, não apenas pelo instigante diálogo na banca de qualificação como pelas trocas ao longo das disciplinas. Agradeço por estar sempre aberto e pelo constante incentivo.

À professora Sylvia G. Garcia, que me ensinou, ainda na graduação, o que é ser cientista social 24 horas por dia e que para fazer um bom trabalho, é preciso dar razões.

Ao grupo de estudos sobre ideologia, do qual fiz parte de maneira tímida e silenciosa. Sou imensamente grata por terem aberto as portas para um universo do qual eu não fazia parte, mesmo sob a minha condição de espectadora. Espero, com este trabalho, tornar público o quanto aprendi com vocês, Bruna, Anouch, Lais, Eduardo, Everaldo, Ugo, Fábio e Vladimir.

Ao grupo Hybris, de onde este trabalho sorveu muitas referências, indagações e questionamentos. O cruzamento de temas aparentemente tão distantes foi e continua sendo absolutamente enriquecedor, permitindo-me ultrapassar fronteiras teóricas e políticas. Agradeço ao Nicolau, à Julia, ao Carlos, à Fernanda, à Dani, à Flor e ao Adalton. Sobretudo à Natacha por compreender muitas vezes as minhas incertezas, e à Catarina, que é uma grande inspiração.

À Anouch e à Lais, pelas conversas infindáveis e por sempre me lembrarem de que eu 
não estava sozinha. À Samantha, pela amizade de anos, pelos incentivos nos momentos de crise e por compartilhar inquietações e questões. Ao Edu, pelas sempre animadas discussões. À Carol e ao Leandro, por estarem sempre presentes. À Andrea pelo apoio na reta final.

Em especial à Bruna, por ter me ensinado, com sua força e sua amizade, o que (e como) é enfrentar este mundo.

A quatro mulheres que, ora de perto ora de longe, acreditaram na importância deste trabalho: minha avó Janette e as tias queridas Sandra, Heleninha e Nádia. Ao Camilo e ao Alexandre, por terem acompanhado e torcido com tanto carinho.

A minha mãe e ao meu pai, por incentivarem e por me oferecerem todas as condições para que eu pudesse ir a campo, passar horas diante dos livros e por nunca duvidarem da importância de tudo isso. Agradeço ainda à minha irmã que, com sua incrível compreensão das contradições do mundo, sempre esteve disposta a ouvir o que é que eu tanto estudo.

Ao Danilo, por estar presente sempre, em tudo o que está por trás e pela frente de todas essas páginas.

Esta pesquisa contou com o apoio do CNPq. 
BÁDUE, Ana Flávia P. L. A nebulosa do decrescimento. Um estudo sobre as contradições das novas formas de fazer política. 181p. Dissertação (Mestrado em Antropologia Social). Faculdade de Filosofia, Letras e Ciências Humanas. Departamento de Antropologia da Universidade de São Paulo, 2012.

Resumo: Esta dissertação de mestrado tem como tema central a mobilização políticoecológica de Decrescimento na França. Com o argumento de que o crescimento econômico destrói o meio ambiente, militantes do decrescimento acionam uma diversidade de coletivos, ações e ideias para construir uma mobilização política em forma de nebulosa. Diferente de um movimento social, de um partido político ou de um grupo com contornos bem estabelecidos, uma nebulosa é uma mobilização descentrada e aberta, que coloca em relação iniciativas distribuídas pelo território francês com a preocupação de garantir a autonomia e a particularidade de cada grupo local. A fim de discutir as implicações dessa forma de fazer política que é frequentemente considerada inovadora, esta dissertação toma como ponto de partida a nouvelle gauche, nascida em meados dos anos 1950 na França. Por meio do levantamento de algumas questões que aparecem nessa nova esquerda, discute-se as implicações do aparecimento de novas maneiras de conceber o social e agir politicamente em detrimento do marxismo, da contradição de classes e da noção de exploração por meio do trabalho. Diante da problematização do conjunto de ideias e práticas que tomava corpo naquele período, parte-se para uma discussão das continuidades e descontinuidades instauradas pelo decrescimento com relação aos movimentos precedentes, através da descrição etnográfica das relações estabelecidas pelos militantes franceses. Por fim, as novas formas de fazer política desenvolvidas pelo decrescimento são problematizadas na medida em que são aproximadas das novas formas do capitalismo. Muitas análises sugerem que a crítica tornou-se o motor do capitalismo por meio da incorporação de formas de organização social e ideológica que tem profundas afinidades com o movimento decrescimento. Dessa forma, são discutidas as contradições de um movimento que tenta colocar o crescimento em xeque.

Palavras-chave: 1) Decrescimento; 2) Ecologia política; 3) Movimentos sociais; 4) Capitalismo 
BÁDUE, Ana Flávia P. L. The nebula of degrowth. A study on the contradictions of new forms of political action. 181p. Dissertação (Mestrado em Antropologia Social). Faculdade de Filosofia, Letras e Ciências Humanas. Departamento de Antropologia da Universidade de São Paulo, 2012.

\begin{abstract}
The aim of this thesis is to discuss the degrowth movement in France. Considering that economic growth leads to environmental damages, degrowth activists state that it is necessary to create new forms of political action. Thus, many informal collectives, practices and ideas are mobilized in order to built what is called nebula of degrowth. Different from a social movement, a political party or a well defined group, a nebula is a non-centered and opened mobilization, that establishes many relations between collectives and groups spread all over the French territory. While the connections are created, many efforts are made to guarantee the differences and autonomy of the groups joined together. To discuss the implications of the nebula form of degrowth, this thesis goes back to the emergency of the nouvelle gauche, during the 1950s. Some issues that usually have shown up in this moment allows us to discuss how society and political action was reconceptualized, for example by the expulsion of marxist ideas such as class struggle and labor exploitation. The mapping of the main points of the new left in France leads us to discuss the continuities and discontinuities introduced by degrowth movement in the political scenery. After an ethnographic presentation of degrowth nebula, the conclusion is that there are many contradictions in the form the movement states social criticism. To explain what are the meanings of such contradictions, a final topic is presented: the contradictions of the contemporary capitalism. By bringing capitalism and degrowth movement aside, it is possible to see that both have similar but opposite forms.
\end{abstract}

Keywords: 1) Degrowth; 2) Political ecology; 3) Social movements; 4) Capitalism 


\section{Sumário}

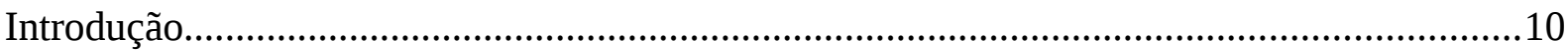

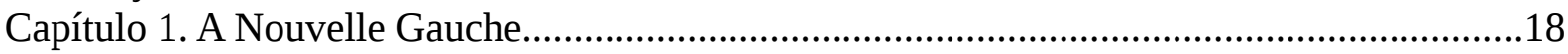

1. 1. O diagnóstico de uma sociedade integrada pela técnica..........................................21

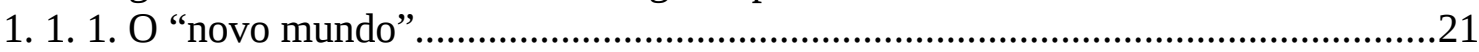

1. 1. 2. A recusa do marxismo e técnica como nova inimiga......................................23

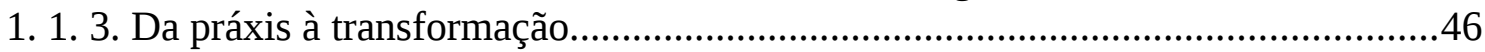

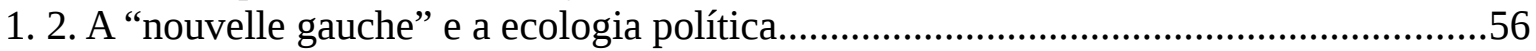

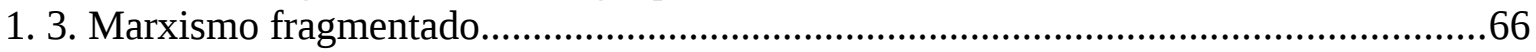

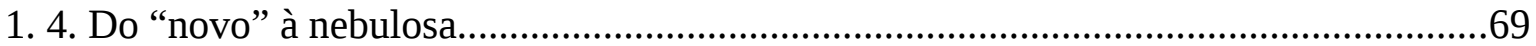

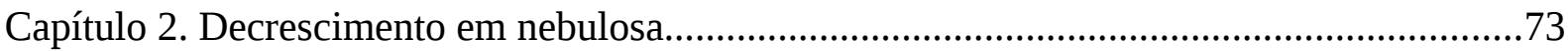

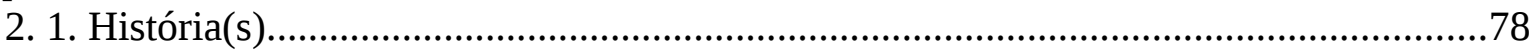

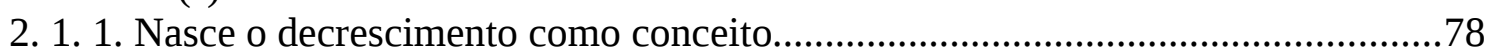

2. 1. 2. Etiquetando e costurando o decrescimento: nebulosa como método...................90

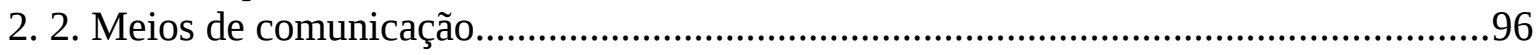

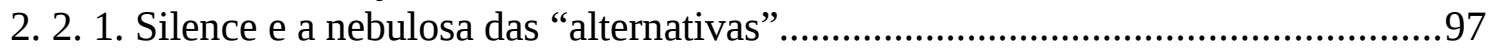

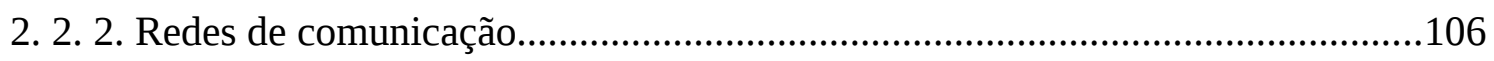

2. 2. 3. La Décroissance: a crítica como ação............................................................110

2. 3. Consumo político, trocas humanizadas e produção justa...........................................117

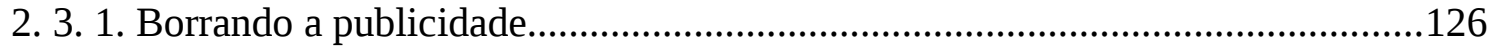

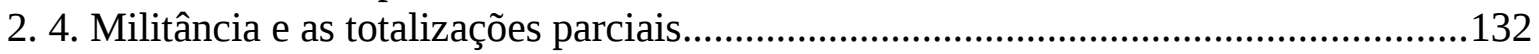

2. 5. A expulsão do outro no "outro possível”...................................................................135

Capítulo 3. Transformações no capitalismo e as contradições da crítica................................138

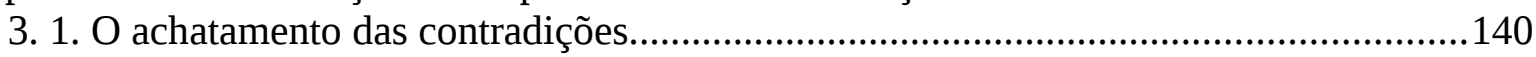

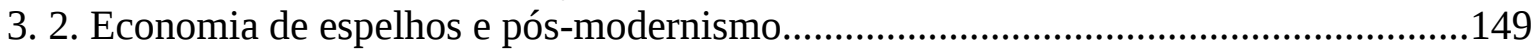

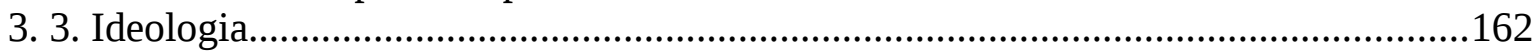

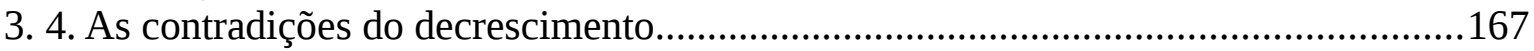

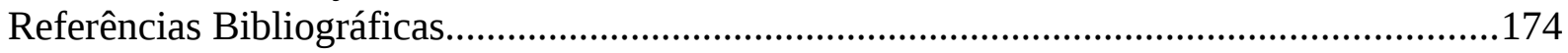




\section{Introdução}

A Ciência Política europeia está passando por um dilema: como estudar política se as instituições políticas (parlamento, eleições, partidos) estão perdendo a credibilidade e a força? Uma série de estudos vem sendo elaborados para tentar "medir” a democracia, para verificar se as pessoas identificam-se com os partidos e qual a confiança que depositam nas instituições democráticas. Segundo dados obtidos pelo Eurobarometer (um conjunto de surveys realizados em diversos países da União Europeia sobre a percepção da economia e da política na $\mathrm{UE}^{1}$ ), europeus declaram acreditar mais em instituições não democráticas como a polícia do que em eleições e partidos. Além disso, os jovens estão depositando sua energia política não mais em militância partidária, mas sim em associações e organizações não governamentais. Por fim, os partidos que tinham amplo apoio popular tem sua participação quantitativamente diminuída nas instâncias de poder, sendo substituídos por uma miríade de novos pequenos partidos cuja base social é de classe média. A consequência disso é a expulsão dos setores mais pobres para fora da política, por um lado, e de outro uma reorganização da ação de jovens de classe média e alta que não parece se encaixar nos moldes tradicionais de partidos e eleições (cf. MERKEL, 2012).

Essas questões, no interior da teoria política, passam por uma série de áreas temáticas, que vão do debate sobre o conceito de democracia até a discussão metodológica sobre a possibilidade de mensurá-la, passando por problematizações filosóficas de representação e legitimidade. Qualquer que seja a perspectiva e a posição adotada, o ponto no qual todas se cruzam é o consenso de que é preciso repensar o que é política na Europa e discutir as instituições e seus limites.

Há cientistas políticos (que declaram-se isolados) que tentam traçar um quadro mais otimista no que diz respeito à aparente falência da participação popular no engajamento político e propõem que as associações, organizações e mesmo coletivos não formalizados que são apontados como substitutos dos partidos pelo Eurobarometer são novas formas de fazer política. Esta visão corresponde aos argumentos acionados pelos próprios militantes que travam batalhas (semânticas e concretas) para mostrar o quão importante é consumir

1 Conferir o site do Eurobarometer: <http://ec.europa.eu/public_opinion/index_en.htm>. 
orgânicos e andar de bicicleta. E mais do que politizar novas esferas da vida, o argumento em voga é que isto se dá por oposição a outras formas de ação que seriam estéreis do ponto de vista da transformação social.

Os planos de austeridade europeus em resposta à crise econômica (que começou em 2008 e que voltou ainda com mais força nos países de capitalismo avançado em 2010) levaram às ruas europeias e norte-americanas multidões de “indignad@s” que reivindicavam “democracia real já”, uma democracia cujas decisões fossem tomadas sem a mediação dos partidos existentes e sem que a política fosse submetida a prerrogativas econômicas. As praças tomadas, como Bellecour em Lyon, eram como arenas nas quais se poderiam ensaiar, em pequena escala, a democracia que se queria levar adiante ${ }^{2}$. Ao mesmo tempo, no interior dos acampamentos, havia um grande problema em jogo: seria preciso fazer a crítica ao sistema contra o qual as pessoas ali presentes se manifestavam ou a própria existência de coletivos auto-geridos daria conta de colocar abaixo a política que servia aos bancos? Esse debate, que tomava as assembleias e as conversas nas praças, abordava a mesma questão que a ciência política europeia aciona: o que é fazer política?

Esta dissertação de mestrado tem como tema central o decrescimento, uma dentre tantas “novas formas de fazer política” que circulam na França - e cujos militantes ${ }^{3}$ estiveram presentes ativamente nas praças europeias durante o mês de maio de 2011. Nascido na esteira dos primeiros Fóruns Sociais Mundiais, no início dos anos 2000, o decrescimento era uma termo que aparecia para sistematizar a crítica ao crescimento econômico e os problemas ambientais e para tornar pública a possibilidade de se construir uma sociedade não baseada nos índices de crescimento e desenvolvimentos.

A novidade conclamada pelo decrescimento residiria em sua forma disforme e por isso democrática: sem um centro, sem um programa comum - deliberadamente - qualquer pessoa ou coletivo pode integrá-lo e transformá-lo, mediante debates e relações com os demais. Diferente de um conjunto de coletividades dispersas, a "nebulosa” do decrescimento é

2 Na Espanha, foram milhares de pessoas que ocuparam praças em Madri, Barcelona e outras cidades. Logo, a pequena escala não significa uma quantidade pequena de pessoas envolvidas, mas sim que havia um acordo sobre as ocupações serem uma forma de protesto e não uma construção imediata de uma sociedade alternativa, como se aquelas praças oferecessem instrumentos para a nova política na medida em que eram organizadas de maneiras "novas".

3 Novas formas de fazer política implicam novas formas de militância. Militar pelo decrescimento, como veremos ao longo deste trabalho, não é pertencer a um grupo de decrescimento, mas defender a causa em diversas situações coletivas e também no modo de vida cotidiano. 
definida por seus militantes como a possibilidade de interconectar iniciativas esparsas e separadas, bem como ações individuais e pontuais e, assim, potencialmente estendê-las para provocar uma transformação social em larga escala.

Por meio dessa forma de organização, o decrescimento é uma mobilização que problematiza o crescimento econômico em função das destruições ambientais que este provoca, mas a miríade de argumentos evocada para fazer essa associação e para propor soluções dificulta propositadamente o elenco de um conjunto de conceitos que definam decrescimento. Há, por exemplo, setores do movimento que enfatizam a dimensão econômica do crescimento; outros colocam a economia como fruto de nosso imaginário consumista, e propõem que a ação deve ser voltada para a transformação das mentalidades. Alguns grupos defendem uma relativa separação temática no interior da crítica ao crescimento e assim as reivindicações seriam melhor atendidas, por exemplo separar a luta contra a publicidade dos problemas ambientais. Ainda há coletivos voltados para a construção de relações entre pequenos grupos (como associações de associações, redes de movimentos, etc.) para evitar que a mobilização se fragmente.

A questão de inovar as formas de fazer política por meio do decrescimento toma corpo nas alianças e nos conflitos entre grupos, pessoas e ideias. Militar pelo decrescimento não é “pertencer” a um grupo bem constituído, mas passar por uma série de coletivos de forma flexível, como que deslocando o compromisso com uma causa que se pretende totalizante para um múltiplo engajamento. Os coletivos, por sua vez, são pequenos, frequentados por um número flutuante de pessoas e a diferença entre uma militante e um simpatizante é difícil de ser estabelecida, como que se isso não fizesse diferença para efetividade da mobilização.

E é exatamente este o ponto mais importante para se compreender o que é decrescimento: a efetividade da mobilização. Como será mostrado ao longo deste trabalho, a reconfiguração da ação política, que é tão debatida em diversos meios (acadêmicos, militantes, nos jornais, etc), passa por uma relação com o fazer: não basta criticar o crescimento, é preciso fazer algo. Aparecem, então, os conflitos em torno do que é este fazer: seria suficiente entregar panfletos na rua, integrar um partido político? Fazer não é apenas organizar descontentamentos (mas, dirão rapidamente as defensoras e defensores do decrescimento, certamente isto é fundamental), e sim fazer o “outro mundo" que se quer quando se nega aquele em que se vive. Decrescimento é colocar em prática a crítica ao 
crescimento (que, por sua vez é elaborada nos livros e debatida em diversas coletividades), não apenas através da publicização dos questionamentos, mas também de formas de ação que supostamente não passam pelas orientações gerais (teóricas e práticas) do sistema o qual se critica.

Muitas das propostas e práticas envolvidas com o decrescimento, apesar de aparecerem aos olhos de jovens militantes como uma novidade, já estiveram presentes nas mobilizações da nova esquerda nos anos 1960. Contudo, apesar das proximidade entre as ações, o que é retomado deste período na construção do decrescimento é menos o repertório das práticas do que a produção teórica de autores como Bernard Charbonneau, Jacques Ellul, Ivan Illich e André Gorz.

No primeiro capítulo da dissertação, retomamos alguns aspectos da esquerda francesa entre as décadas de 1950 e 1970, tanto aqueles que são explicitamente mencionados pelos militantes do decrescimento quanto os que não são. A partir de uma retomada de pontos centrais da obra produzida naquele contexto por Charbonneau, Ellul, Gorz e Illich, bem como de algumas questões que perpassavam diversas mobilizações, pode-se perceber que mais importante do que o modo como o meio ambiente era problematizado naquele contexto era a proposta de reformular a compreensão da sociedade, a crítica e as formas de ação política.

A reformulação da crítica pela nova esquerda dizia respeito à expulsão do marxismo dos partidos comunistas, bem como de conceitos e explicações que pareciam estar superadas (como as classes sociais e a exploração do trabalho), sob a justificativa de que o mundo mudara consideravelmente e novas análises precisavam ser feitas e novas formas de ação seriam necessárias para mudar essa realidade social. Entravam em cena, ainda, novos atores, como cientistas e estudantes de classe média.

Embora os movimentos daquele momento sejam vistos hoje com ressalvas por terem fracassado, se estabelecemos pontos de contato entre aquelas mobilizações e o decrescimento atualmente, percebemos que na verdade a nova esquerda teve efeitos bastante significativos com relação à renovação da compreensão do social e das estratégias políticas. Ao defender que na nova formação social não mais eram mais as classes operárias que eram exploradas, mas toda a sociedade que, por meio do consumo de massas e do Estado de Bem Estar Social se via submetida aos imperativos da técnica até mesmo as esferas subjetivas não escapavam ao seu jugo, já estava em jogo a organização de formas de mobilização que colocavam em 
xeque certas categorias sociais ao lançar propostas e reflexões sobre autonomia, autogestão, ações locais e micropolíticas.

Em termos mais abstratos, a força da multiplicação de pontos de vista e de movimentos fragmentados corresponde a uma supressão da noção de contradição como motor da organização social. As teorias que defendiam o fim das classes, por exemplo, propunham que a sociedade não era mais marcada por uma cisão interna, porque toda a população estava igualmente submetida ao totalitarismo das técnicas e do progresso. O novo fenômeno da alienação não se dava mais pelo trabalho, defendiam muitos pensadores e militantes daquele momento, e sim pela determinação de todas as esferas da vida por técnicas heterônomas, ou seja, que subvertem as necessidades, desejos e princípios humanos transformando-os em seus produtos.

A reformulação da esquerda passava também por uma recusa de uma centralização política e ideológica (aqui no sentido de conjunto de ideias políticas), que reverberava nas formas de ação pontuais e fragmentadas, nas quais o corpo, a alimentação, a sexualidade e os modos de vida assumiam papel preponderante. O próprio marxismo, que tanto fora avaliado naquele momento como fracassado e insuficiente incorporou as críticas que recebia. A partir de um breve levantamento dos rumos do marxismo na França nos anos 1960, sugerimos que a descentralização e a recusa de um corpo coeso de conceitos e projetos de mobilização também marcaram-nos.

O efeito da combinação entre recusa de teorias totalizantes de um lado e explosão de lutas pontuais baseadas nos modos de vida de outro foi a consolidação de uma esquerda que entende a ação por meio do fragmento, que perde de vista a totalidade social, seja como modo de organização ou como alvo das mobilizações. Anos depois, quando emergem os movimentos anti-globalização, essa fragmentação é potencializada mas também é problematizada por movimentos como o do decrescimento, que busca restabelecer alguma percepção de totalidade ao mesmo tempo que se esforça para não recair em formações totalitárias.

No fim dos anos 1990, quando surgem os movimentos anti-globalização, os problemas contra os quais estes se colocavam eram significativamente distintos daqueles vivenciados pela nova esquerda trinta anos antes. Ao mesmo tempo, não se pode dizer que não houvesse qualquer continuidade entre ambos períodos. O decrescimento, que nasceu nesse contexto, 
sempre foi marcado por uma recusa da centralização de ideias por determinados grupos, como se a própria existência do movimento passasse por sua forma disforme. O segundo capítulo faz uma descrição dessa multiplicidade de coletivos, pessoas, ideias e conceitos que compõem o decrescimento e atenta para a ênfase da ação militante na “construção de relações”, como uma maneira de evitar que pequenos gestos e pequenas coletividades restem isoladas e não produzam efeitos socialmente relevantes.

É comum, como já foi dito, que os militantes definam o decrescimento como uma nebulosa, composta por meios de comunicação, sites, jornais e revistas, produtores, lojas e restaurantes de alimentos orgânicos, coletivos anti-publicidade e uma miríade de associações ligadas a temas diversos. As relações são o mote destas pequenas organizações, ou seja, não bastaria agir pontualmente produzindo orgânicos se esta produção não fosse um modo de religar produtores e consumidores, de restabelecer laços de amizade onde o dinheiro havia provocado despersonalização das relações. Entre este e outros casos, o decrescimento aparece como uma dupla resposta às formas “precedentes” de fazer política: de um lado, recusando a ação tradicional (como militância partidária) e de outro, problematizando a herança "new age” dos anos 1960, isto é, das iniciativas individuais de levar estilos de vida alternativos que em nada mudariam o mundo. Em suma, por meio de uma série de discussões, o segundo capítulo traça um mapeamento de alternativas militantes e problematiza o que está em jogo quando se propõem novas formas de fazer política que passem tanto pelos modos de vida quanto pelos investimentos de criar conexões que não suprimam as especificidades e diferenças - efeito das mobilizações da nova esquerda quarenta anos antes.

A continuidade entre os dois períodos é, portanto, mais profunda do que uma mera transmissão de conteúdos e de repertórios de ação e de reflexões. Ao enfatizar as relações entre as lutas fragmentadas que a nova esquerda havia lançado no campo do político, o decrescimento procurou restabelecer uma dimensão de totalidade que ao mesmo tempo fica ameaçada pelo princípio organizador de não territorializar o decrescimento em lugar algum.

A hipótese final deste trabalho, desenvolvida no terceiro e último capítulo, é que esta oscilação contraditória do decrescimento corresponde à outra contradição, que é sua relação tensa com o capitalismo contra o qual se erige. Ao se constituir como uma nebulosa de alternativas (seja no plano do pensamento ou das ações concretas), o decrescimento retoma, à sua maneira, a ideia de “outro mundo possível” postulada pelos movimentos antiglobalização 
da virada para o século 21. Alternativas a quê, poderíamos perguntar? Não apenas ao crescimento econômico, mas também ao neoliberalismo, à manipulação dos desejos pela publicidade, à estetização da política, entre tantos outros questionamentos que são apresentados no segundo capítulo.

O terceiro capítulo é, então, uma reflexão feita com base em diferentes abordagens sobre o capitalismo contemporâneo com o objetivo de apreender como o alvo das lutas do decrescimento se organiza. A partir desse quadro, nos deparamos com contradições no movimento pois, na medida em que se opõe a uma série de elementos que constituem o capitalismo, acaba se aproximando dele através de sua forma nebulosa de estabelecer relações que constituem totalidades parciais e ao acionar a diferença como motor de sua existência. Por outro lado, há que se levar em conta que estão envolvidas na nebulosa do decrescimento motivações de resistência que, diante de um diagnóstico de falência da mobilização social de massas, encontram suas armas de luta no cotidiano e na articulação de gestos pontuais. Uma vez que o capitalismo incorporou a crítica (como forma e não o conteúdo específico de alguma crítica em particular), parece não haver mais lugar para sair dele; se seu motor é a própria possibilidade de crítica, ele irá sempre se perpetuar como versões diferentes de si mesmo. Mas fica a questão: será que o movimento de decrescimento também não instaura rupturas que desafiam um pensamento teleológico, e cujo efeito não pode ser previsto?

\section{Nota etnográfica}

O trabalho de campo que deu origem às questões desenvolvidas nesta pesquisa de mestrado foi realizado em Lyon, terceira maior cidade francesa, em março de 2010 e maio de 2011, mas antes de ir a França, a pesquisa já estava em curso a partir do levantamento diário de textos que circulavam na internet com a palavra décroissance 4 . Foi em campo que me deparei com uma inesperada rede de pequenos coletivos, pelos quais as pessoas circulam e constroem imagens de mundo a partir de sua perspectiva militante, de modo que pude recortar

4 Por meio de uma ferramenta do Google, recebo em minha conta de e-mails todos os dias as notícias publicadas que contenham a palavra décroissance. Entre 2008 e 2010 organizei o material em um banco de textos. 
como tema da pesquisa de mestrado a organização “em nebulosa” do decrescimento.

É importante apontar, de início, que muitos grupos, pessoas, ideias, propostas e ações ficaram de fora deste trabalho, não apenas pela economia do texto, mas pela impossibilidade (constitutiva do movimento) de acompanhar todos os grupos. Durante esses dois meses, acompanhei uma série de atividades e movimentações organizadas por pessoas e coletivos que defendem diretamente o decrescimento, como o jornal La Décroissance, a revista Silence, e a Entropia ou por grupos que se dizem afeitos à ideia de decrescimento, como o Deboulonneurs, o Les Compostiers, o bazar 3 p'tit pois, o restaurante Le Court Circuit, entre outros, de modo que eu mesma fui considerada militante. Foram realizadas algumas entrevistas mas o meio principal de adentrar na nebulosa foi segui-la diariamente.

A simples fala de que eu estava em Lyon para estudar o decrescimento me colocava diante da forma descentrada da mobilização: imediatamente meus interlocutores acionavam uma série de pessoas e de coletivos com os quais eu deveria estabelecer contato. Entre tantas indicações, algumas referiam-se a autores já mortos que teriam levantado precocemente o tema do decrescimento, como aqueles sobre os quais me detive no segundo capítulo. Passei a intercalar a pesquisa sobre mobilização social e correntes teóricas da chamada nova esquerda. Os temas escolhidos para serem trabalhados no primeiro capítulo foram de certa forma originados das questões que motivam o decrescimento contemporâneo e, por essa razão, foram feitos recortes e muitas questões importantes levantadas pelos autores em particular e pelos movimentos da década de 1960 em geral não foram contemplados nesta dissertação.

Por fim, o caráter aparentemente mais teórico e menos empírico do último capítulo está profundamente relacionado com toda a pesquisa de campo que realizei e com os estranhamentos e contradições vividas pelos próprios militantes. Mais do que um capítulo "separado" que busca explicar e dar sentido a todas as questões previamente levantadas, busquei realizar textualmente um procedimento metodológico de passar das partes ao todo e do todo às partes, bem como do geral ao particular e vice-versa. 


\section{Capítulo 1. A Nouvelle Gauche}

Não se deve perguntar qual o regime mais duro, ou mais tolerável, pois é em cada um deles que se enfrentam as liberações e as sujeições. [...] Não cabe temer ou esperar, mas buscar novas armas.

Giles Deleuze

O decrescimento é tanto um movimento político-ecológico, quanto um princípio de vida, como ainda um conjunto de teorias sociais, econômicas e políticas. O ponto comum entre as diversas formulações do decrescimento é a constatação da insustentabilidade ecológica e social do crescimento econômico que, mensurado por índices de produção de bens e serviços e de consumo, encontraria seus limites na exploração da natureza, já que um mundo de recursos naturais finitos parece dar sinais de esgotamento frente a níveis de crescimento cada vez maiores. Em termos muito genéricos, quem se diz favorável ao decrescimento concorda que o crescimento infinito não é absolutamente compatível com um mundo de recursos naturais finitos.

O crescimento econômico nem sempre é o único ponto a ser explorado por militantes e acadêmicos. Há temas e questões paralelas que circulam nos meios acadêmicos e/ou militantes e que complementam a construção da inteligibilidade do termo, permitindo localizá-lo como algo distinto de uma oposição semântica ao crescimento ${ }^{5}$. É o caso da problematização dos padrões de consumo dos países industrializados do Norte, tema que parece ocupar certo lugar de consenso: opor-se ao crescimento passaria, inevitavelmente, por uma crítica feroz ao consumismo e à publicidade.

Os pontos de convergência são, contudo, provisórios, no sentido de que nem sempre são abordados da mesma maneira por quem defende o decrescimento. A crítica à sociedade do consumo pode ser o ponto de partida de certas coletividades, mas ser o ponto de chegada de

5 Para ficar mais claro, pensemos em como a palavra decrescimento aparece no Brasil: não a identificamos com um grupo de pessoas ou um conjunto de ideias. Decrescimento é apenas a palavra que indica o contrário de crescimento, seja econômico, físico, estatístico. Na França, o termo décroissance entrou para o dicionário Petit Larouse em 2009 como "politique préconisant un ralentissement du taux de croissance dans une perspective de développement durable" (BONAL, 2009). Porém, grande parte dos outros dicionários dão como definição termo "diminuição". 
outras. Uma heterogênea massa de ideias, propostas, críticas, sugestões, ações práticas, coletivos e associações propõem versões distintas de decrescimento e é comum que os próprios militantes do decrescimento nomeiem aquilo que aparece a uma observadora externa como um mosaico como uma "nebulosa”. Como ficará evidente no próximo capítulo, as diferenças são consideradas a forma de existência do decrescimento, como uma recusa em sistematizar um conceito de decrescimento exclusivo e unívoco. Por isso o decrescimento é considerada pelas pessoas engajadas uma nebulosa - e não propriamente de movimento social, nem é reduzido à teoria do decrescimento ou a determinadas maneiras legítimas e corretas de praticar o decrescimento.

O decrescimento se constituiu em um momento de efervescência de mobilizações sociais e ambientais nos anos 2000, ao mesmo tempo em que muitos militantes remontam aos anos 1960 e 70 como fonte de inspiração. Autores como os franceses Jacques Ellul, Bernard Charbonneau, André Gorz, Cornelius Castoriadis e François Partant, o romeno Nicolas Georgescu-Roegen, o austríaco Ivan Illich e o inglês Ernst Friedrich Schumacher seriam de certa forma referências para a elaboração do pensamento e das propostas de decrescimento, já que todos eles teriam, de um modo ou de outro, apresentado de forma sistemática questões relativas aos malefícios da sociedade de consumo e à insuficiência (social e ecológica) do crescimento econômico (cf. BESSON-GIRARD; LATOUCHE, 2006).

O projeto de uma sociedade autônoma e econômica abarcado pelo slogan do decrescimento não é de ontem. Sem remontar a algumas utopias do primeiro socialismo, nem à tradição anarquista renovada pelo situacionismo, ele foi formulado, desde o fim dos anos 1960 e de uma forma muito próxima da nossa, por André Gorz, François Partant, Jacques Ellul, Bernard Charbonneau, mas sobretudo por Cornelius Castoriadis e Ivan Illich. O fracasso do desenvolvimento no Sul e a perda das referências no Norte levaram esses pensadores a questionar a sociedade de consumo e suas bases imaginárias.

LATOUCHE, 2009, p. 13.

Além de evocados atualmente como precursores de algumas das ideias do decrescimento, os próprios autores tiveram alguma participação com o movimento atual. Ivan Illich participou da conferência Défaire le développement, réfaire le monde (ILLICH, 2002) e Gorz escreveu o último artigo de sua vida, amplamente noticiado pela internet em sites do decrescimento, para a revista eletrônica EcoRev' (GORZ, 2007). Ellul, Charbonneau, Gorz e Ellul produziram uma série de trabalhos entre os anos 1950 e 1970 que nem sempre foram 
imediatamente reconhecidos. Contudo, este período de suas produções tornou-se referência e, mesmo os trabalhos mais recentes aparecem como se fizessem parte de uma obra cuja importância decorresse das reflexões produzidas naquele momento ${ }^{6}$. Tais autores mantiveram profundo diálogo entre si. Ellul e Charbonneau trabalharam juntos desde a juventude, como ambos relatam em diversos trabalhos. Charbonneau foi o "mestre" intelectual de Illich (cf. ILLICH, 1994), que por sua vez tornou-se referência obrigatória para Gorz depois que este começou a se engajar nas questões de saúde, ciência e tecnologia (cf. GORZ, 2008).

Duverger (2011) sugere que o decrescimento apenas reabilitou, sob a forma de movimento social, um debate que já estava posto quatro décadas antes do qual tais autores citados por Latouche eram expoentes. Que debate seria esse? Neste capítulo, serão levantados alguns temas desenvolvidos por André Gorz, Jacques Ellul, Bernard Charbonneau e Ivan Illich para compreender o que era evocado, mobilizado e enunciado naquele momento e que retorna hoje pela via do decrescimento. Ao selecionar a obra desses quatro autores, o objetivo é evitar generalizações acerca daquele período e mostrar como estavam sendo produzidos conhecimentos sobre a realidade social e propostas de transformação. Ao mesmo tempo, a fim de localizá-los em seu tempo, serão apontadas algumas linhas gerais do que se convencionou chamar de nova esquerda francesa, de ecologia política e do marxismo que entrava em colapso como referência unívoca. O duplo movimento de refinar as referências de um lado (aprofundar a apresentação dos quatro autores) e generalizá-las de outro (pela nova esquerda, pela ecologia política e pelo marxismo fragmentado) é ao mesmo tempo um modo de apresentar o procedimento utilizado pelos defensores do decrescimento hoje e usá-lo como estratégia textual para relacionar parte e todo. Como diz David Harvey (2012), a proximidade ajuda a revelar as microtexturas de que são compostas as grandes pinceladas - e abrir mão de uma implica abrir mão da outra.

Entre as generalizações feitas sobre os anos 1960 e 1970 na França, estão aquelas que falam sobre a "nouvelle gauche”: a nova esquerda francesa que se constituiu para responder às crises do socialismo real, ao imobilismo e autoritarismo do comunismo internacional e às transformações sócio econômicas decorrentes das altas taxas de crescimento na França. Uma das características sempre lembradas dessa nova esquerda é sua multiplicidade, no sentido de

6 Um exemplo é o livro Finis Terrae de Bernard Charbonneau (2010), que foi escrito na década de 1990 mas que é apresentado como se fosse um trabalho imediatamente associado às reflexões que o autor produziu nos anos 1970 . 
ser praticamente inviável traçar linhas comuns. Ao invés de mapear tudo aquilo que se considerava como nova esquerda, ou de buscar todas as linhas gerais para conseguir classificar os quatro autores, parece ser mais interessante levantar os elementos que se tornaram significativos na reorientação da esquerda e que hoje marcam a crítica do decrescimento e sua forma de mobilização social. Isso significa que o quadro apresentado adiante acaba deixando de fora uma série de debates e questões, como a sexualidade e o feminismo, que foram de suma importância para o momento mas que hoje não estão imediatamente ligados ao decrescimento.

O que liga os autores aqui escolhidos ao decrescimento contemporâneo é menos uma preocupação propriamente ecológica e a problemática da natureza propriamente dita. Decerto apareciam considerações sobre o meio ambiente, mas na maior parte das vezes eram como uma chave de acesso a problemas maiores: a questão da liberdade e da autonomia. O que levou esses autores a serem reconhecidos tantos anos depois como importantes pensadores da ecologia política são suas formulações acerca de um mundo novo, em transformação, que exigia novas reflexões, questionamentos e intervenções.

\section{1. O diagnóstico de uma sociedade integrada pela técnica}

\section{1. 1. O "novo mundo"}

Entre 1945 e 1973 a França (bem como os demais países de capitalismo avançado, cada qual com sua especificidade) foi marcada pela racionalização extrema da indústria amadurecida no entre-guerras, por elevados níveis de crescimento econômico, pelo aumento do padrão de vida (aumento de salários reais e de renda familiar), pela contenção de tendências a crise e a conflitos bélicos e pela preservação da democracia de massas. O crescimento teve como fundamento uma reformulação dos papeis dos atores envolvidos nesse fenômeno: o Estado passou a intervir pesadamente na economia e nas relações corporativas; o capital corporativo teve que se ajustar a reivindicações dos sindicatos e estes, por sua vez, para ter suas reivindicações salariais e de políticas sociais atendidas ofereciam em troca a cooperação às técnicas fordistas de produção para garantir o aumento de produtividade (cf. HARVEY, 2012). Além disso, o regime soviético apontava sinais de crise e os partidos socialistas e comunistas fora da URSS representavam cada vez menos os grupos de esquerda, 
descontentes com uma série de fatores do regime.

Esse período, que ficou conhecido como os Trinta Gloriosos (ou Anos Dourados do capitalismo), colocava para a esquerda, uma série de problemas relativos a como interpretar e compreender essas relações sociais, econômicas e políticas e como lutar contra elas. Era comum que se definisse aquela realidade como uma novidade radical, no sentido de romper completamente com o passado. Conforme Angela Alonso (2009, p. 59), naquele momento dizia-se que "uma mudança macroestrutural teria alterado a natureza do capitalismo, cujo centro teria deixado de ser a produção industrial e o trabalho. Uma nova sociedade se vislumbraria, dando lugar também a novos temas e agentes para as mobilizações coletivas”. O marxismo começou, assim, a ser visto por certos setores da esquerda francesa como insuficiente para dar conta desse contexto. O mundo parecia não mais corresponder à cisão de classes, como se todas as pessoas agora tivessem sido igualmente submetidas à técnica; logo, a transformação social não dependeria mais de uma luta “interna” à sociedade, mas de uma recusa a algo que lhe é exterior e lhe determina de "fora".

A indústria, a técnica e a ação humana deixam de figurar como solução para o futuro para se converterem em problema presente, causadoras de problemas sociais, ambientais e, mais do que isso, um perigo à liberdade. Como mostra Jean Jacob (1999), os anos 1960 e 70 foram marcados pelo fim das esperanças oferecidas pela razão. A ciência não mais levaria a um futuro melhor e inelutável, o progresso parecia ter deixado de ser solução e tornou-se problema, a industrialização elevou o nível de vida material, mas teria sido responsável por novas formas de restrições às liberdades humanas.

Além disso, divulgava-se o fracasso do socialismo real e consequentemente parte da esquerda recusava o Partido Comunista e a União Soviética como referências ou paradigmas. Por fim, tudo isso estava associado à reconfiguração dos problemas diante da emergência de novas questões, como a ecologia, o feminismo e a sexualidade. As fronteiras sociais, políticas e territoriais dos problemas se transformaram: uma vez que o poder passa a ser problematizado como algo que opera sem centro e por meio de pequenos gestos e em relações sociais que antes não eram problematizadas como tais (como a escola, o turismo, a saúde, etc), esse poder (e a dominação) não mais estava associado a grupos específicos nem era mediado por determinadas relações sociais, de modo que todo o mundo parecia estar sujeito aos mesmos mecanismos de controle e dominação. 


\section{1. 2. A recusa do marxismo e técnica como nova inimiga}

Atualmente, o marxismo é uma questão que aparece entre os militantes do decrescimento, mas em menor medida se comparado com o debate crítico das décadas de 1950 a 70 na França. Parece haver um certo consenso sobre sua derrocada dada sua suposta insuficiência; mas antes de haver um consenso (que é frequentemente questionado em alguns textos ou em algumas conversas entre militantes), houve um momento em que foi preciso explicitar as razões para tirar o marxismo de cena.

Dificilmente o marxismo era qualificado ou adjetivado porque era sempre identificado com aquilo que se proferia e se executava nos partidos comunistas, que respondiam ao PC da União Soviética. Algumas vezes, o diálogo fazia parte de uma tentativa de reabilitar Marx e a crítica ao capitalismo fora do circuito do partido comunista sem abrir mão da posição questionadora e da perspectiva de transformação social. Charbonneau, Ellul, Illich e Gorz oscilavam muito entre desferir golpes violentos às proposições de Marx e entre historicizá-lo, garantindo um status de importância à obra de Marx, mas que era limitada por ser datada no tempo e no espaço. Novas análises deveriam ser feitas para explorar pontos aos quais Marx não teria dado a devida atenção ou que não teria vislumbrado dado o momento em que seu trabalho foi produzido. Muito do que se convencionou chamar de nova esquerda e as teses dos quatro autores tinham o objetivo de ser uma nova luz para reabilitar a crítica social sem necessariamente ter que passar pelo arcabouço teórico-político marxista.

Um dos elementos que se mobilizava com certa frequência para estabelecer uma distância com relação ao marxismo vigente era a crítica ao socialismo real. Charbonneau (1973) identificava a União Soviética aos Estados Unidos a fim de mostrar que os problemas sociais e ambientais não eram exclusivos de um regime ou de outro, já que ambos compartilhavam a ideologia do progresso. Além disso, tanto em um sistema com em outro, as estruturas técnicas dominantes moldavam as formas de vida cotidiana suprimindo a liberdade de todos os indivíduos. Ellul dizia que o grande problema nos anos 1930 e 40 era saber "com qual tempero seremos devorados: hitlerista, stalinista ou americano" (ELLUL, 1982b, p. 12), ou seja, todos os sistemas apresentavam grandes ameaças totalitárias e deveriam igualmente ser combatidos.

Illich, que viveu no México e em Porto Rico por muitos anos, direcionava sua críticas sobretudo aos Estados Unidos e às intervenções deste país na América Latina, mas não 
deixava de compartilhar com Ellul e Charbonneau, reflexões sobre o socialismo. Afirmava que os mesmos processos se verificavam nos países capitalistas e socialistas: contraprodutividade, subdesenvolvimento e monopólio radical ${ }^{7}$. Argumentava que, uma vez que a industrialização elimina a política, pouco importava a orientação do país: a industrialização imperava, gerando um crescente dano irreparável em todos os setores, em todas as partes do mundo. A ênfase na industrialização fazia com que o socialismo e o capitalismo "falassem o mesmo idioma" ao classificar as sociedades por seu grau de desenvolvimento (ILLICH, 2006a, 2006b).

André Gorz, nos anos 1960, discordava que se pudesse comparar os regimes capitalistas entre si bem como comparar capitalistas e socialistas, mas verificava um processo comum a todos: a subordinação do consumo à produção e das necessidades, exigências criadoras, cultura e educação às exigências do processo de acumulação (GORZ, 1968a, 1968b). Em suma, em nenhum dos países as necessidades econômicas respondiam às exigências de libertação humana; pelo contrário, as finalidades humanas se submetiam às técnicas. Isso se passava porque a acumulação também teria orientado o socialismo real, mas ao invés de ser privada, ali era pública.

A aproximação dos regimes capitalistas e socialistas implicava uma revisão das teorias sociais que preconizavam os segundos como alternativa (e por vezes inevitável) aos primeiros, levando inevitavelmente a um diálogo, senão uma ruptura, com o marxismo, já que este, na visão dos autores em questão e de muitos outros contemporâneos, não conseguia dar conta de uma nova realidade que subjugava todo o mundo, independentemente do regime político.

\section{Charbonneau e a grande metamorfose}

Ellul e Charbonneau se conheceram ainda jovens, quando faziam parte do movimento personalista. O personalismo foi uma corrente filosófica fundada por Emmanuel Mounier como uma alternativa à leitura marxista economicista disponível naquele momento para explicar as crises pelas quais passava a Europa desde 1929. Segundo essa corrente, a pessoa era o cerne das relações sociais, por oposição às estruturas totalitárias e ao individualismo. A pessoa era concebida como uma relação dialética, como um ser cuja existência é uma relação

7 Esses conceitos serão desenvolvidos adiante. 
contínua de conflitos entre a exteriorização e a interiorização. O personalismo era, assim, também um projeto social uma vez que sugeria a plena realização dessa existência, da conciliação entre a pessoa e a vida comunitária uma vez que apessoa era a referência de todas as ações humanas (cf. PEIXOTO, 2010).

A perspectiva personalista de Charbonneau e Ellul já prenunciava na década de 1930 as teses que publicariam nos anos 1950 e 1960. Conforme escreveram no "Diretivas para um manifesto personalista”, texto de 1935 publicado na revista Esprit, coordenada por Mounier, a organização social, política e econômica que vivenciavam funcionava sem passar pelas escolhas reais dos indivíduos, que agora se viam subjugados a uma ordem que lhes era exterior (CHARBONNEAU; ELLUL, 2011). Nesta sociedade, a renúncia ao ser humano, à consciência, à medida humana levou a um quadro no qual não são mais pessoas que dominam pessoas, mas as fábricas, as instituições, o Estado, o lucro, os armamentos que dominam a humanidade, minando as liberdades humanas. O personalismo seria uma nova civilização que só se alcançaria mediante um novo estilo de vida verdadeiramente humano. Aquilo que é verdadeiramente humano é feito por "juízos que nós temos sem pensar, pelas nossas reações em face a todos os eventos diários" (CHARBONNEAU; ELLUL, 2011, p. 155). Seria como uma conjugação entre espontaneidade e consciência.

A questão central para os dois amigos era a perda da liberdade provocada pela hipertrofia das estruturas técnicas e de gestão, mais do que com uma eventual "crise de civilização" (CÉRÉZUELLE, 2006, p. 20). Eles pretendiam mostrar que as experiências totalitárias não foram uma anormalidade, uma exceção, mas ao contrário, a sociedade contemporânea herdara, por meio da técnica, o totalitarismo. Essas reflexões pautaram toda a obra subsequente de ambos os autores. Em 1937, Charbonneau escreveu o que hoje é considerada uma das primeiras reflexões ecológicas publicadas na França, intitulada Le sentiment de la nature, force révolutionnaire. Desde então, juntamente com Ellul, passou a refletir sobre os custos e consequências do progresso tecnológico (INGRAND, 2012; LAURENCIN, 2010). Por conta disso, ambos enfrentaram resistência do marxismo que predominava entre a esquerda francesa no pós-guerra, porque contestar o progresso, depois da ocupação nazista, parecia ser muito reacionário; as palavras de ordem eram reconstrução e produção (CÉRÉZUELLE, 2006).

Charbonneau distancia-se de Ellul, contudo, no método de exposição de suas questões. 
Reconstruir sua argumentação de forma linear é uma tarefa difícil (diferentemente de Ellul) já que o próprio autor buscava uma alternativa às abstrações científicas. Em seus livros e demais trabalhos fica evidente de que maneira a prática da escrita lhe soava como uma redução da sensibilidade, da oralidade e da experiência ${ }^{8}$. As palavras crescimento, desenvolvimento, técnica, burocracia e economia são muitas vezes tratadas como equivalentes, sem que haja uma preocupação em filiar-se a uma linguagem conceitual rigorosa.

Sua proposta era que, pelo caráter poético e pouco sistemático, fossem apresentadas reflexões sobre a realidade das sociedades (sobretudo europeias) depois do fim da Segunda Guerra Mundial. Em 1973, Charbonneau publicou o livro Le système et le chaos, no qual propunha a tese de que a autonomização da ciência e da técnica no capitalismo e no socialismo levaram à destruição da liberdade humana porque invadiram todas as esferas da vida social e individual com suas leis e com sua organização. De acordo com a interpretação de Cérézuelle (CÉRÉZUELLE, 2006, 2012), Charbonneau fez convergir uma série de problemas sociais na expressão "grande metamorfose” (que, na verdade, não é definida como um conceito e aparece em uma série de textos).

Em diversos textos, Charbonneau fala sobre uma contradição entre a natureza do ser humano de criar meios para facilitar sua vida, por um lado, e a autonomização desses meios e a consequente destruição da liberdade humana, de outro. Como veremos adiante, essa contradição não deveria ser eliminada, mas sim, equilibrada. Antes de chegarmos ao projeto do equilíbrio, vamos ver como Charbonneau desenvolve sua argumentação a respeito dessa contradição.

Na primeira parte de Le systéme..., dedicada à emergência da razão e da ciência, Charbonneau defende que a recusa da tradição, o questionamento das verdades religiosas e o racionalismo levaram à transformação do universo em uma máquina eficaz. Paradoxalmente, essa mesma máquina tornou-se pesada, abstrata e complicada. Com a objetividade, o conhecimento se descolou do sujeito, não havendo mais bem e mal nem a responsabilidade sobre os frutos da ciência, pois tudo é apenas objetivo, neutro. Consequentemente, a técnica que nasceu para responder certas necessidades se autonomizou com relação a seus fins

8 Um exemplo da preocupação de Charbonneau em escapar da escrita científica e das abstrações foi o prefácio para um livro de fotografias de Maurice Bardet intitulado La fin du paysage (1972). Segundo Cérézuelle, Charbonneau "mostra” mais do que "demonstra" e é isso que caracteriza seu método expositivo, articulado com seu projeto teórico-político (CÉRÉZUELLE, 2006). 
(valores, julgamentos) e acabou se convertendo ela própria em um fim, sobretudo por meio das leis científicas que acabam por atribuir à ciência um caráter normativo. Em suma, a ciência melhorou a condição das massas, mas ao mesmo tempo concentrou na mão de poucos especialistas (e não na mão das massas) a autoridade e o poder (CHARBONNEAU, 1973).

Charbonneau defendia que o processo que se verifica na ciência espraia-se por todas as dimensões sociais por meio da técnica, fazendo com que a vida humana, tanto individual quanto coletiva, seja organizada segundo os princípios da eficácia. Era como se a sociedade tivesse se autonomizado frente ao indivíduo, que fica restrito à sua vida privada, de onde sai ocasionalmente para participar da "política", nas eleições ou participando de sindicatos. A espontaneidade desaparece quando a vida social passa a ser mediada.

Isso significa que a técnica não é só máquina, já que para que uma cadeia qualquer funcione é necessário que tudo esteja integrado e que haja uma organização de tudo o que está envolvido. Quando essa organização é feita de forma hierárquica, aparecem novas técnicas de controle na figura da administração. O Estado, a economia, a propaganda, a urbanização, o turismo e o lazer, a relação com a natureza, a burocracia, tudo isso são mediações técnicas da vida social. Outras formas intermediárias de associação (entre sociedade global e indivíduo), como os sindicatos, desapareceram ou entraram na lógica administrativa. Delegou-se o poder de união e articulação social ao Estado, ao qual cabe agora a organização da sociedade.

No sistema em que a técnica impera, a economia ocupou lugar fundamental por ser a nova religião universal. Até então, a economia não era algo separado, não tinha consciência de si mesma. Segundo Charbonneau, “a burguesia inventou a economia política; ela pretendia governar as nações em função de suas próprias leis naturais e sagradas, as leis do lucro. E como é preciso produzir para ganhar, a Produção se transforma no valor supremo, mais do que a propriedade ou as finanças” (CHARBONNEAU, 1973, p. 101). O dinheiro passa a funcionar nessa mesma lógica como um signo que submete tudo à economia, que serve à produção e à técnica. Tornou-se um signo que media as relações privadas enquanto o Estado, análogo ao dinheiro, tornou-se mediador de relações públicas e também tem como finalidade única a produção ${ }^{9}$.

9 Segundo Cérézuelle (2006), Charbonneau confere importância fundamental ao Estado na constituição da nova configuração social pautada pela técnica. Com a Primeira Guerra, os Estados viram-se diante da necessidade de controlar a produção de forma total, unificada e eficaz. Assim, a organização e a eficácia foram se espraiando para outros setores, resultando em uma totalização social. 
Neste mundo, no qual as prerrogativas da produção industrial imperam em todas as dimensões, Charbonneau defende que não faz mais sentido pensar em termos de luta de classes. No capitalismo, a exploração do trabalhador é menos para enriquecer o patrão e mais para enriquecer a indústria, daí sua afirmação que o trabalhador se libertou do capital para se submeter à produção. A exploração do trabalhador agora não se dá mais pelo homem, mas pela economia, e todas as pessoas passam a ser igualmente exploradas como recursos naturais. O dinheiro e o Estado não servem a classes específicas, mas à produção, bastaria ver que uma parte da mais-valia sempre volta para a aquisição de novas máquinas e meios de produção, afirma Charbonneau (ibid: 105).

Charbonneau seguiu algumas aulas do curso sobre Marx ministrado na Universidade de Bordeaux por seu amigo Jacques Ellul. É muito interessante notar que, apesar desse conhecimento, Charbonneau quase não cita Marx em seus textos mas vê-se que o diálogo era bastante vivo. Em um relato, Michel Rodes conta que seu toda militância de seu amigo Charbonneau se deu em termos de lutas político-ecológicas, contra uma série de transformações territoriais nas pequenas cidades francesas mas não menciona qualquer referência ao marxismo. Ao fim do relato, Rodes lembra rapidamente que Marx foi uma influência de Charbonneau uma vez que seu pensamento "se caracterizava pela sua notável capacidade de frustrar e denunciar paradoxos”. (RODES, 2012, p. 135). Ao mesmo tempo, Charbonneau teria seguido outro caminho: o estilo "incisivo, pitoresco, que vai do detalhe mais realiza à síntese mais magistral”, a ênfase nas transformações técnicas, a crítica à colaboração entre a universidade e a indústria, a recusa de uma linguagem hermética na descrição da realidade.

Marx aparecia, então, como uma inspiração mas também como algo a ser superado. No lugar da suposta centralidade da economia em Marx, Charbonneua adotava uma perspectiva que jogava luz sobre outros domínios sociais. A organização torna-se palavra de ordem em todos eles. O Estado como técnica política, por exemplo, assume a organização do trabalho para garantir o pleno emprego. Mas o pleno emprego nada mais é que a submissão de todas as pessoas à produção. Por isso Charbonneau diz que a produção é totalitária: ela impõe sua organização por todas as esferas para que possa continuar funcionando. Assim, ao invés de a organização permitir um controle da economia para que esta seja o meio, ela faz o inverso. 
O mesmo processo se dá com as cidades e a urbanização: no início, a cidade era um espaço de liberdade, pois era o lugar do individualismo. Mas, em nome da proteção individual, o planejamento urbano e regulações diversas minaram a liberdade (CHARBONNEAU, 1988). Além disso, se por um lado a cidade teve sucesso em permitir ao homem escapar da natureza, por outro, elas se transformaram em meio totalmente artificial. Esse argumento se confirmaria pelo fato de que as pessoas viajam para o campo para se libertar da vida na cidade.

Uma das consequências do espraiamento da técnica por todas as dimensões do social é que não faz mais sentido, ressalta Charbonneau, pensar a sociedade exclusivamente em termos de classes, uma vez que todos estariam igualmente submetidos a um único sistema. A burocracia, por exemplo, é uma forma de unir a organização humana com a organização das máquinas. Ela se despersonaliza cada vez mais, assim como o Estado, fazendo com que o poder não se concentre mais nas mãos de pessoas determinadas, mas que todos o exerçam igualmente para fazê-lo funcionar. Não há, então, uma diferença essencial entre as classes, não há mais dominadores de um lado e dominados de outro e todos se associam em um aparelho burocrático, mesmo que alguns tenham excelentes salários e outros não. Até mesmo os diretores servem ao sistema mas sua autoridade é garantida e exercida para amenizar e esconder sua posição de servidão.

Podemos falar de uma "era dos gerentes", de uma tecnocracia? Eles formam uma classe dirigente, tal como fora a burguesia, que buscam conscientemente obter a conquista do poder e justificam-na por uma ideologia? [...] Eles não são uma classe, eles são a sociedade.

CHARBONNEAU, 1973, p. 94.

Dentro desse novo sistema, novas diferenças reconfigurariam as relações sociais e a existência humana. Em termos mundiais, os países podem ser divididos entre desenvolvidos e subdesenvolvidos - os que estão totalmente organizados e os que ainda resguardam espaços de espontaneidade e não-organização técnica. E como a técnica e a ciência também são palavras de ordem no socialismo da URSS, as diferenças entre os países não decorreriam do regime político. Por fim, há ainda outro critério de diferenciação social no interior das sociedades técnicas, que diz respeito à oposição entre campo e cidade. O marxismo e o socialismo "reduziram a questão social à oposição da burguesia e do proletariado", mas burguesia e proletariado "têm com efeito a mesma religião da indústria e o mesmo terreno de 
jogo - a cidade. Para um como para outro, o campo é um corpo estranho que se suporta pior ou melhor, enquanto se aguarda o momento de eliminá-lo, brutalmente pela revolução e metodicamente pela técnica" (CHARBONNEAU, 1988, p. 37).

A lógica totalizante da grande metamorfose não implica em uma real unidade social. Segundo Charbonneau, a unidade real só existe na medida em que há diferença, pois se não há diferenças, não há trocas, não há comparações ${ }^{10}$. As diferenças que de fato existem em nossa sociedade são produto da divisão do trabalho, que é acompanhada pela segregação espacial nas cidades entre classes de ricos e pobres. Somente o dinheiro distingue os homens e mulheres, e é o dinheiro que os une.

Outra consequência da grande metamorfose é a perda da liberdade dos indivíduos. As máquinas, a organização, a burocracia, os saberes técnicos e científicos especializados controlam as forças sociais e podam as relações materiais e sociais espontâneas e livres. Se o progresso nasceu para libertar o homem de Deus e das antigas formas sociais, ele trouxe novos sofrimentos, observa Charbonneau. O produtor é reduzido à produção e o consumidor, ao consumo. As técnicas, as máquinas e a administração nos dão novos membros, mas atrofiam os antigos.

Os indivíduos sequer podem ter ideias e correr riscos, já que o Estado organiza tudo e até mesmo cria um sistema de seguridade social. Para que a produção continue em perfeito funcionamento, todo o risco (exceto a guerra) deve ser garantido pelo Estado, que assume formas burocráticas e replica os métodos de trustes privados a fim de garantir a ordem social. Homens e mulheres repetem os mesmos gestos nas mesmas máquinas enquanto a televisão impõe a mesma distração para todas (os). Não há mais espontaneidade, as pessoas têm tarefas bem definidas e uniformizadas e suas relações são mediadas pelo dinheiro e pela organização impessoal. O efeito subjetivo da ausência de espontaneidade e de liberdade é a angústia. Diante das mudanças constantes e das novas necessidades que devem ser supridas, o resultado é um sentimento de que nunca conseguiremos atingir a felicidade (CHARBONNEAU, 1973, p. 187).

10 Charbonneau chega a mencionar Lévi-Strauss para dizer que o fim da multiplicidade é também o fim da sociedade e embora o primeiro não recorra à teoria das trocas do segundo, vemos que Charbonneau inspirase nos trabalhos sobre esse tema para definir a sociedade em vias de desaparecimento. 
Ivan Illich, contraprodutividade e monopólio radical

Ivan Illich era católico e fez parte do clero, assim como Jacques Ellul. Na década de 1960, devido às críticas que fazia à Igreja Católica acabou por desligar-se dela. Essas críticas eram profundamente ligadas as suas teses sobre subdesenvolvimento e sobre a desfuncionalidade da escola e de missões religiosas (ILLICH, 1973a, 1973b). Nesse momento, sua obra se separava em duas frentes que dialogavam: a primeira era mais voltada a temas teológicos e religiosos e a segunda era "panfletária", defendia a tese da contraprodutividade do desenvolvimento (ROBERT; PAQUOT, 2010). Apesar de sua extensa trajetória (a partir de 1980, Illich adentra um período de reflexões sobre o poder e a função simbólica de instrumentos conceituais e sobre a relação entre oralidade e escrita), a fama de Illich pelo mundo fez-se, segundo Robert e Borremans (2006) por seus escritos panfletários, que hoje são referência para o decrescimento.

Tais escritos abordam diversos temas como educação, saúde e energia, todas atravessadas por um mesmo processo: a contraprodutividade e o monopólio radical. Nas sociedades industrializadas (capitalistas e socialistas), os meios se converteram em fins, gerando o fenômeno da contraprodutividade, defendia Illich. A contraprodutividade designa o modo como o desenvolvimento e o progresso carregam em si sua destruição; tanto biofísica, quanto social e também política (contraprodutividade das ferramentas, instituições e da sociedade industrial). Illich verificava isso nos transportes, na educação e na saúde - três temas importantes para a análise já que, segundo o autor, são os elementos do desenvolvimento e da modernidade por excelência.

Segundo o comentário de Boaventura de Sousa Santos (1975) sobre o panfleto “Energia e Equidade”, Illich buscava provar a lei hegeliana da transformação da quantidade em qualidade. Veja-se o caso do consumo de energia: ultrapassando-se determinado limite, há um "efeito corruptor do poder mecânico" (ILLICH, 1975, p. 27), qual seja a transformação desse poder mecânico em necessidade, e a necessidade converte-se em um monopólio:

Tal monopólio institui-se quando a sociedade se adapta aos fins daqueles que consomem o total maior de quanta de energia, e enraíza-se irreversivelmente quando começa a impor a todos a obrigação de consumir o quantum mínimo sem o qual a máquina não pode funcionar.

ILLICH, 1975, p. 60.

Quando tudo é reorganizado em torno dos meios de transporte motorizados, não resta 
espaço para outra forma de transitar (por exemplo, as bicicletas), e as pessoas veem-se obrigadas a se transportarem por meio de um produto industrial. Isso significa que o produto industrial converte-se em necessidade - a necessidade de locomoção transforma-se em necessidade de ter um carro - como se a indústria e o processo técnico passassem a deter um monopólio radical sobre as necessidades. A esse processo de inversões Illich dá o nome de coisificação e afirma inspirar-se em Marx e Freud: "por coisificação quero significar a consolidação da percepção das necessidades reais numa procura de produtos manufaturados de massa. Ou seja, a transferência da sede para a necessidade de uma Coca-Cola" (ILLICH, 1973c, p. 210). A "rendição da consciência social às soluções pré-acondicionadas" se dá na medida em que organizações burocráticas conseguem dominar a imaginação dos consumidores - sobretudo pela propaganda.

O monopólio cria, então, duas alienações: a primeira diz respeito ao alheamento das necessidades, que passam a ser produzidas externamente, pelo processo técnico e industrial; a segunda vem do fato de que só mercadorias produzidas pela indústria serem capazes de satisfazerem essas necessidades forjadas. Daí a expressão monopólio radical para designar o duplo controle da indústria e das instituições sobre a vida humana (criando falsas necessidades e sendo as únicas a disporem de meios para satisfazê-las).

Com relação à indústria do transporte, Illich argumenta que houve uma configuração do espaço em função do transporte motorizado, provocando a extinção das relações humanas e do comércio local, bem como ocasionando uma dependência do carro para qualquer deslocamento. "Ao ultrapassar certo limite de velocidade, os veículos motorizados criam distâncias que só eles conseguem reduzir" (ILLICH, 1975, p. 48), e quem não dispõe de veículos motorizados, não consegue se locomover. O carro também reduz a liberdade de trânsito no sentido que reduz as possibilidades de destino - quem está a pé pode mudar sua rota, parar onde quiser, enquanto quem está de carro não pode fazê-lo e tem que seguir rotas desenhadas especificamente para automóveis.

Além da geografia, o transporte motorizado também altera o tempo social quando o aumento do raio de circulação é acompanhado por um maior dispêndio de tempo com o trânsito. Somando todo o esforço de uma pessoa para dirigir (tempo de trabalho para comprar o carro e pagar as contas mais o tempo dirigindo), uma hora seria equivalente ao trajeto de apenas seis quilômetros. Em países onde não há carros, uma pessoa também passa uma hora 
para se deslocar por seis quilômetros, com a diferença de que gastam apenas 3\% da sua vida se movimentando, contra os 25\% gastos em países "motorizados", calculava Illich (2006c). A transformação da quantidade em qualidade sobre a qual falava Boaventura de Sousa Santos, diz respeito, assim, a uma nova forma social na qual a tecnologia se sobrepõe às relações da humanidade entre si e com a natureza. O desenvolvimento da indústria, afirma Illich, se dá em detrimento da plena participação das pessoas, da autonomia dos indivíduos e dos grupos de base.

O mesmo se passa com a medicina: assim como o transporte motorizado implica imobilidade e escravização da maioria das pessoas ao carro, a medicina prolonga o tempo da doença e cria novas normas a cada nova doença descoberta. A esse fenômeno da produção de doenças, sofrimento e morte pela própria medicina Illich dá o nome de iatrogênise. Soma-se a isso o encarecimento dos serviços médicos, cujo efeito é a criação de uma população submissa e dependente, que ao mesmo tempo que não consegue mais recorrer a seus próprios meios para a cura, não tem acesso aos serviços médicos (ILLICH, 2006a). Antes, a cultura oferecia mitos, tabus e padrões éticos para tratar a vida, a doença e as relações sociais. Com a legitimação da medicina, a dor, a doença e a morte são tratadas por vias institucionais, de modo que quem não se submeter a esses mecanismos não consegue mais lidar com a dor e com a morte. Como destaca Illich, "a promessa do progresso conduz à recusa da condição humana e à aversão à arte de sofrer” (ILLICH, 1999 s. p.).

A educação é outra dimensão na qual o monopólio radical e a contrapodutividade se verificam, quando o aprendizado se reduz à escolarização. O direito a aprender só se realiza pela escola (ILLICH, 2006d) e, mais do que isso, só por seu intermédio podem ser formadas as elites dirigentes e profissionais que orientam a sociedade. Em países pobres, a escolarização é ainda mais difundida, na medida em que somente pela escola que se obtém um diploma, o qual é necessário para a inserção na sociedade de consumidores disciplinados da tecnocracia (ILLICH, 1973d) ${ }^{11}$.

Nos países latino-americanos investiu-se em educação com vistas a "tirar a maioria não-rural da sua marginalidade nos bairros de lata e numa agricultura de subsistência e levá-la para o tipo da fábrica, de mercado e de vida cívica correspondentes à tecnologia moderna"

11 Embora as aproximações com Bourdieu e seus trabalhos sobre a escolarização na França sejam muitas, Illich não faz referências a este e não consta, nos comentários consultados, qualquer sinal de que tenha existido alguma relação entre ambos. 
(ILLICH, 1973e, p. 140). Mas concretamente a educação não gerou os frutos prometidos. Ao contrário, a escola produziu frustração porque aparece como garantia de integração social, mas não a realiza porque, na medida em que marginaliza aqueles que não a seguem, produz uma classe de pobres impotentes, ao lado de uma elite escolarizada (ILLICH, 2006d). A escolarização, que nasceu para incorporar as pessoas ao Estado industrial e que serviu para derrubar o feudalismo, tornou-se um "ídolo opressor" que só protege aqueles que já foram educados, produzindo desigualdades.

Essa realidade não é exclusiva de países pobres, assevera Illich. Nos EUA a educação também é aquilo que designa quais pessoas são qualificadas ou não. A diferença maior é: enquanto em países ricos há escola para todos, em países pobres, não há. Mas nestes, a escola aparece como o único meio de acender à riqueza, de modo que representa um fardo (ILLICH, 1973e, p. 155). Era o caso de Porto Rico, que investira 30\% de seu orçamento governamental em educação, mas apenas pequena parcela chegava ao mundo universitário. Nas palavras de Illich, Porto Rico foi escolarizado, mas não instruído.

Illich não explica, entretanto, as razões da pobreza e não deixa explícito se a escolarização, a medicalização e o carro são produto de uma desigualdade a priori ou se as instituições operam de forma contraditória produzindo desigualdades entre aqueles que a consomem e aqueles não o fazem. Na maior parte dos textos, a impressão que se tem é que as desigualdades estão dadas de antemão, já que, ao menos nos países pobres, o acesso às instituições pressupõe a posse de dinheiro e muitas são as pessoas que não conseguem fazer parte delas. Essa questão não é respondida porque Illich está mais preocupado com a “oposição que se situa primeiro entre os homens e a estrutura técnica da ferramenta e, logo, como consequência, entre o homem e as profissões cujo interesse consiste em manter a estrutura técnica” do que com “a oposição entre uma classe de homens explorados e outra classe proprietária das ferramentas” (ILLICH, 2006a, p. 468).

Ao tentar contornar a questão das classes, Illich oscila entre duas explicações. Ora é o sistema que cria as desigualdades, ora ele se impõe a uma realidade já cindida. Os diplomas criam uma diferenciação social, mas essa diferenciação só se dá a partir de uma diferença anterior: os que tiveram e os que não tiveram acesso ao ensino formal, conseguiram diplomas e tiveram acesso a bons empregos. Com os carros, passa-se uma ambiguidade semelhante. Illich afirma que o automóvel nasceu como produto de luxo, o que quer dizer que existem 
ricos e pobres antes que o trânsito se transforme em espaço exclusivo de veículos motorizados. E uma vez que isso ocorre, os transportes criam uma desigualdade social entre os que têm e os que não têm carro, mas Illich não incorpora essa questão em seus trabalhos.

\section{André Gorz e a autogestão}

Gorz era um revolucionário anti-autoritarista e anti-stalinista e um crítico das estratégias do movimento de trabalhadores via partido. Antes de começar a se dedicar à ecologia, nos anos 1970, Gorz estava preocupado com a configuração do capitalismo contemporâneo (GORZ, 1968a, 1968b). A primeira fase do pensamento de Gorz, quando ele se define como marxista, é pouco mencionada atualmente como referência ao decrescimento. São seus trabalhos que dialogam com a ecologia política que se tornaram importantes. Assim como os demais autores, essa importância decorre menos da problematização da questão ecológica propriamente dita e mais da maneira como Gorz correlaciona a explicação social com a crítica por oposição à tradição marxista então existente.

Os trabalhos de Gorz dessa época são muito próximos às constatações de Illich e também de Ellul e Charbonneau no que se refere ao diagnóstico de uma nova forma social desenvolvida com o pós-guerra, bem como à submissão das necessidades e criatividade humana à técnica. Gorz entrara em contato com os trabalhos do grupo de Illich no fim da década de 1960 e lera os manuscritos de Nemesis Médica em 1974. Sua impressão, na época, foi de que Illich revigorava as teorias de Ellul:

A expansão das indústrias transforma a sociedade em uma gigantesca máquina que, em vez de libertar os humanos, restringe seu espaço de autonomia e determina como e quais objetivos eles devem perseguir. Nós nos tornamos os serviçais dessa megamáquina. A produção nação não está mais ao nosso serviço; nós é que estamos a serviço da produção. E em razão da profissionalização simultânea dos serviços de todos os tipos, tornamo-nos incapazes de cuidar de nós mesmos, de autodeterminar as nossas necessidades e satisfazê-las por nossa conta: dependemos, para tudo, de 'profissões incapacitantes'.

GORZ, 2008, p. 54.

Ao mesmo tempo, ele distancia-se desses autores ao articular a submissão à reconfiguração da classe trabalhadora e à produção de capital. Em suma, Gorz procedia de maneira similar, mas usava um vocabulário marxista, numa tentativa de reabilitá-lo ao invés de superá-lo. 
Como dizia Charbonneau, a competição entre EUA e URSS criou um novo critério de comparação entre os países: instituiu um novo sistema de produção e consumo voltado para o bem estar e para o crescimento. Foi a primeira vez, de acordo com Gorz, que se travou uma ligação imediata entre crescimento econômico e consumo final, substituindo a industrialização maciça como sinônimo de crescimento econômico. Para que o sistema continue em funcionamento, é necessário que as pessoas necessitem comprar e usar dos serviços oferecidos pelo sistema, donde a manipulação das necessidades e desejos.

Ao mesmo tempo em que o novo capitalismo tem os olhos voltados para os desejos das massas, estas não poderiam ser deixadas por sua própria conta, afinal era preciso que se consumisse cada vez mais para que o crescimento continuasse. Foi assim que a publicidade assumiu papel central no sistema, cabendo a ela criar desejos e necessidades entre as massas de consumidores. Tudo se passa, entretanto, como se a economia se desenvolvesse para satisfazer as necessidades humanas, mas a realidade, segundo Gorz, é que as necessidades são forjadas para produzir lucro (GORZ, 1991).

Era comum que a padronização dos comportamentos e aspirações dos indivíduos fosse vista com bons olhos naquele momento, como um processo de aburguesamento do proletariado. Evidentemente, Gorz opunha-se a essa visão otimista e defendia que a homogeneização produzia uma dominação generalizada, sendo que tanto proletários como colarinhos-brancos padeciam de alienações similares, à medida que as necessidades mais íntimas se sujeitam à determinação do capital.

O neocapitalismo (termo que Gorz utilizara em sua fase marxista) caracteriza-se também por uma reconfiguração da organização do trabalho, ou melhor, da divisão do trabalho. As empresas passaram a obedecer critérios impessoais e objetivos de funcionamento, que requeriam especialização tanto das camadas dirigentes quanto das massas e a produção deixou de estar sujeita a determinações pessoais ou de classe. No lugar do empresário individual apareceram grupos de técnicos especializados em planejamento e organização racional que tentavam suprimir qualquer imprevisto, improvisação e qualquer intervenção pessoal. Quanto ao proletariado, este foi quantitativamente reduzido e qualitativamente transformado em mão de obra qualificada. A isso Gorz dá o nome de heteronomia (GORZ, 1978): as pessoas se transformaram em engrenagens de um mecanismo que não mais lhes diz respeito. 
A composição das classes sofreu, com isso, uma grande transformação: além de todos terem se tornado peças do mesmo sistema, a exploração agora é despersonalizada, no sentido de que não há um grupo que personifique o papel de explorador. Charbonneau diagnosticava também a "despersonalização" de todo o sistema e dava pistas de que isso alterava a composição das classes. Enquanto a reconfiguração significava para Charbonneau a possibilidade de não mais se falar de classe, Gorz não abandona de imediato o vocabulário marxista, mas acaba articulando-o à questão que lhe parece mais central e importante, qual seja, a autonomia.

Quando Gorz começou a se engajar com questões ecológicas ${ }^{12}$, conferia especial atenção à questão da heteronomia provocada pela submissão das necessidades e desejos à técnica. Os trabalhadores, que haviam sido substituídos por mão de obra qualificada são, na visão de Gorz, substituídos por máquinas. Tais máquinas custam caro e seu valor é repassado para a mercadoria. Na concorrência, cada capitalista busca rentabilizar suas máquinas o mais rápido possível, investindo em máquinas mais eficazes, mais caras e que necessitam de menos trabalhadores para aumentar a produtividade. Assim, a composição orgânica do capital muda (diminui o capital investido em salários e aumenta o investido em máquinas) promovendo uma queda tendencial da taxa de lucro. Se o lucro cai, torna-se mais difícil investir em novas máquinas mais caras, pois há menos dinheiro. Ao processo segundo o qual o peso do capital na produção cresce de tal modo ele não mais consegue se reproduzir em ritmo normal, Gorz dá o nome de sobreacumulação (GORZ, 1978). É como se Gorz estivesse diante de uma contradição: a tendência do capital de investir em máquinas produtivas para manter seu crescimento leva a uma inviabilidade de crescimento porque os lucros caem.

Em “O Capital”, Marx estabelece uma relação complexa entre capital variável e constante, sendo que Gorz parte dessa reflexão para definir a sobreacumulação. O trabalho vivo cria novo valor ao mesmo tempo que conserva os valores dos meios de produção: “é portanto um dom natural da força de trabalho em ação, do trabalho vivo, conservar valor ao agregar valor, um dom natural que nada custa ao trabalhador mas que rende muito ao capitalista” (MARX, 1984a, p. 162). As máquinas apenas repassam seu valor à mercadoria que produzem, sem criar valor novo, cabendo ao trabalho vivo criar novo valor de uso e fazer

12 Esse engajamento se estendeu por toda a sua vida. Em 1991 publicou o livro Capitalisme, socialisme, écologie, composto por artigos recentes publicados em outros locais. Contribuiu também com artigos para a revista EcoRev'. 
reaparecer o valor de troca que é repassado dos meios de produção para a nova mercadoria. Aquela parte do capital investido que apenas reproduz seu valor no processo produtivo é o capital constante (são máquinas, matérias-primas, ferramentas). Já a força de trabalho é a parte que muda de grandeza (passa de valor de uso para mais-valia) - o capital variável. Este é responsável por criar a mais-valia, que é efeito do duplo processo de criação e reprodução do valor.

A criação de valor pelo trabalho vivo é escamoteada pela taxa de lucro, que é um cálculo da economia política burguesa, explica Marx. A taxa de lucro é a variação do capital (mais-valia) sobre a composição orgânica do capital (capital constante + capital variável). A taxa de mais-valia é a razão entre mais-valia e capital variável, afinal o capital constante apenas é repassado para a nova mercadoria sem depositar nela qualquer novo valor. Portanto, se o capital constante aumenta historicamente mas a exploração da mais valia continua existindo no pouco trabalho que ainda compõe o capital, a taxa de exploração de mais-valia pode continuar e crescer, mesmo que a taxa de lucro diminua - e tende a diminuir.

A razão para o capital constante aumentar sempre está no próprio funcionamento do capital. Marx afirma que o ciclo do capital nunca se encerra. O fim de um ciclo é o ponto de partida de outro: o dinheiro do capitalista passa para a forma de mercadoria, e desta para a forma dinheiro e assim sucessivamente. Para além da reprodução simples (do próprio capitalista que pode comprar com o dinheiro pertences para si mesmo), parte da mais-valia pode ser consumida como renda, e parte pode ser aplicada como capital ou ser acumulada. Então, na medida em que a mais-valia é utilizada como capital, o novo capital é fruto da maisvalia convertida em capital (e consequentemente, do trabalho morto objetificado nos meios de produção). É isso que Marx chama de "acumulação de capital".

Tão logo o capital adiantado seja composto pela mais-valia produzida no ciclo anterior, a propriedade se congela do lado do capitalista, como se não houvesse qualquer participação do trabalho humano. O sistema é, portanto, tautológico: apropriação da maisvalia dá o direito de apropriação de novas mais-valias. E para realizar a acumulação de capital, é preciso que o capitalista não consuma todo o mais-produto do qual se apropriou, e sim que o use como meio de produção de novo capital ${ }^{13}$. Para isso, é necessário que hajam elementos materiais para uma nova produção (meios de produção, meios de subsistência para

13 Neste ponto, Marx faz uma torção da tese Weberiana da ética ascética cristã. É como se o "ponto de vista” dos capitalistas não fosse o motor do capital, mas fosse movido por ele. 
o trabalhador e trabalhadores).

Parte do mais-trabalho anual tem de ser empregada na fabricação de meios adicionais de produção e de subsistência, em excesso sobre o quantum que foi necessário para a reposição do capital adiantado. Em uma palavra: a mais-valia só é transformável em capital porque o mais-produto, do qual é o valor, já contém si componentes materiais de um novo capital.

MARX, 1985, p. 164

Dada uma quantidade de mais-valia, o capitalista que é seu proprietário pode investir em novos meios de produção ou em si mesmo, mas a ética e a moral fazem com que ele prefira a primeira à segunda. O investimento no aumento da massa de meios de produção destinada a ser transformada em capital é um aumento do capital constante, mas ao mesmo tempo a acumulação de capital gera uma população sempre já disponível para ser explorada (MARX, 1985), de modo que a "a massa de mais-trabalho apropriável e apropriado tem de crescer” (MARX, 1984b, p. 168 - grifo do autor). Ao mesmo tempo, a mesma lei que aumenta a massa absoluta de lucro é a que leva a uma taxa decrescente de lucro, porque a composição do capital tende a se transformar com a acumulação que ela própria gerou.

Voltando, agora, à Gorz, este não aborda a sobreacumulação como uma contradição entre taxa de lucro e taxa de mais-valia e, consequentemente, entre capital de um lado e trabalho de outro - tanto que no fim de sua vida defende que há a possibilidade de haver uma libertação do trabalho dado o aumento do progresso técnico. Para evitar a crise da queda tendencial da taxa de lucro, Gorz afirma que os capitalistas adotam duas medidas: diminuir o tempo útil dos produtos para aumentar o número de mercadorias vendidas, por um lado, e sofisticar produtos para que seus preços aumentem cada vez mais, por outro ${ }^{14}$. Ambas as soluções, por sua vez, encontram novos problemas. A produção cada vez maior de bens implica a utilização de recursos naturais finitos como água e petróleo; o consumo de bens descartáveis gera uma quantidade cada vez maior de lixo. Mas essa nova crise não pode ser resolvida tão facilmente quanto a outra, porque a contradição agora não é interior à lógica do sistema, e sim vem de fora, dos limites da natureza - e eis que Gorz defende ser seu pulo do gato que Marx não teria conseguido perceber. O setor de serviços, como educação, saúde e

14 Gorz não leva em conta os investimentos na diminuição de custos no processo de produção (que afeta o trabalho vivo) como medida adotada pelos capitalistas para superar o problema da queda tendencial da taxa de lucro. 
turismo é, na visão de Gorz, uma forma que o capitalismo encontrou de criar mercadorias imateriais sem que implique no extermínio dos recursos naturais.

Pode-se ver, aqui, um desenvolvimento particular por parte de Gorz da ideia de contraprodutividade proposta por Illich. A tese de Illich é que a contraprodutividade era consequência da utilização de recursos naturais a partir de determinado nível. Já para Gorz, a contraprodutividade é inerente ao sistema, pois o crescimento é uma exigência do capital e supõe um investimento que acaba por limitar o próprio crescimento do lucro. E quando o capital acha uma solução para essa crise, essa solução carrega em si outra crise, agora ecológica. A contraprodutividade é, portanto, uma contradição que se desdobra de outras contradições do capitalismo (como a queda tendencial da taxa de lucro).

Segundo o próprio autor, as análises de Illich sobre contraprodutividade e monopólio radical são muito próximas daquilo que os marxistas entendem como extensão das relações de produção para outras esferas (GORZ, 1978). No trânsito, por exemplo, verifica-se a contradição entre prerrogativa de crescimento ilimitado e limites físicos e naturais. Quando o automóvel se popularizou e todas e todos passaram a ter a possibilidade de um rápido deslocamento, a velocidade diminuiu para menos do que a velocidade de um ciclista. Para solucionar a situação, são construídas mais vias e mais pistas, mas o resultado é sempre o mesmo: quanto mais espaço, mais carros podem circular e consequentemente mais congestionamento, repercutindo em todo o entorno das cidades, como em Paris, afirma Gorz. E mesmo que o carro tenha trazido a imobilidade, o Estado capitalista suprimiu as ligações ferroviárias entre cidades e entre bairros ${ }^{15}$. O que restou foram trens de grande velocidade e companhias aéreas, que agora controlam o tráfego de longas distâncias. O problema se estende também para a dimensão da individualidade. Completa Gorz. O condutor deixa de possuir e dominar seu meio de transporte para se tornar usuário e consumidor do automóvel porque seu veículo o obriga a consumir e utilizar uma enormidade de bens e serviços que só podem ser oferecidos por terceiros.

Paradoxo do carro: aparentemente, ele conferia a seus proprietários uma independência ilimitada, permitindo-lhes deslocar-se por horas, em itinerários de sua escolha, a uma velocidade igual ou superior à estrada de ferro. Mas, na verdade, essa autonomia aparente era paralela a uma

15 A extensa malha ferroviária francesa, que começara a ser construída no século XIX, vai perdendo espaço no entre guerras para a construção de estradas. O asfalto cobriu a França e em 1936 e desde então o serviço público de transporte coletivo tornou-se um grande problema para o governo francês. Para um desenvolvimento histórico e as transformações da rede ferroviária francesa, cf. (RIBEILL, 1985). 
dependência radical: diferente do cavaleiro, do charreteiro ou do ciclista, o condutor do automóvel dependeria de energia para alimentar o carro, assim como dependeria de comerciantes e especialistas em carburação, lubrificação, iluminação, troca de peças para resolver qualquer pequeno problema.

GORZ, 1978, p. 80.

Processo semelhante se dá com a energia nuclear, na opinião de Gorz e novamente vemos as aproximações com Illich. Uma sociedade baseada na energia nuclear é uma sociedade policiada já que são especialistas que cuidam da produção energética, que compartilham um código fechado e inacessível às pessoas e, em nome dele, exercem a dominação. A divisão do trabalho, por um lado, e o monopólio da megamáquina, por outro, viabilizam o controle do capital, pois não permitem a autogestão e monopolizam a reunificação dos trabalhos fragmentados. O Estado ocupa aí um papel importante de centralização da produção energética, não abrindo espaço para a produção local autogerida de energia.

Falar em contraprodutividade é, para Gorz, fazer uma crítica das relações de produção capitalistas fundadas na divisão social do trabalho. Por divisão do trabalho Gorz se refere à separação social dos trabalhadores e a sua alienação com relação aos meios de produção para que sirvam exclusivamente ao capital - e quanto maior o sistema, mais controle o capital pode ter. Se o capital controla a organização social do trabalho, também controla a dimensão técnica, que por sua vez, não é neutra e sim submetida à produção. Por exemplo: moinhos de vento foram extintos não por sua ineficácia, mas porque o vento é acessível a todos e isso poderia colocar a produção capitalista em xeque, afirma Gorz. O capitalismo produz apenas as técnicas compatíveis com sua lógica de dominação, convertendo as técnicas em matriz das relações de poder, das relações sociais de produção e da divisão hierárquica do trabalho. A energia nuclear, por exemplo, supõe e impõe uma sociedade hierarquizada, centralizada e policiada.

Todas essas questões apareciam a Gorz como facetas de um problema maior: o desaparecimento das condições da autodeterminação humana. Agora, quem determina tudo, da produção econômica aos desejos mais íntimos, é o capitalismo e os trabalhadores estão impossibilitados de produzir aquilo que necessitam ou desejam. O operário trabalha servindo à máquina ao invés de servir-se dela. Isso atrofia as faculdades dos indivíduos e sua 
capacidade de produzirem a si mesmos enquanto a divisão social e territorial do trabalho esfacela as relações sociais. Por conseguinte, esse esfacelamento é suprido pela atividade institucional do Estado: proteção, saúde, educação. "Esse deslocamento da sociedade civil para o Estado corresponde, no plano político, à substituição da auto-regulação pela héteroregulação" (GORZ, 1978, p. 47).

Na análise de Gorz, é o capitalismo que, para se reproduzir, produz a heteronomia: criam-se novas formas de trabalho (racionalidade e impessoalidade) e novas necessidades (definidas pelo sistema e não pelas pessoas) para que a acumulação de capital se mantenha. Neste ponto, Gorz afasta-se de Illich, Ellul e Charbonneau, para os quais a lógica da acumulação capitalista não é o fundamento da sociedade contemporânea, mas é a técnica que domina todas as dimensões de uma só vez, inclusive a economia. Gorz parece sugerir o percurso inverso, atribuindo à acumulação do capitalismo um papel preponderante no aparecimento de uma nova configuração social em que a técnica impera - portanto há uma relação entre sua obra de juventude e a produção dos anos 1960. Essa é também a compreensão de Isabelle Lamaud (2012), segundo a qual Gorz dedica-se à luta contra o capitalismo, um sistema econômico de produção, consumo e alienação dos trabalhadores que coloca a seu serviço o desenvolvimento técnico científico e o Estado - e a questão ecológica sobre a qual se debruça é um meio (entre outros possíveis) para colocar em xeque a dominação do capital e do trabalho.

\section{Jacques Ellul, da técnica à integração}

De 1947 a 1979, Ellul deu um curso de marxismo no Instituto de Estudos Políticos de Bordeaux. Marx parecia oferecer instrumentos poderosos para pensar a sociedade. Mas, dizia Ellul, era preciso compreender as diferenças do capitalismo no final do século XIX e o capitalismo do fim do século XX: enquanto a economia dominara no primeiro momento, agora era a técnica. Na sociedade industrial de tipo capitalista, dizia Ellul, a verdadeira força produtiva do valor era é o trabalho; já na sociedade técnica, as máquinas funcionariam sem intervenção humana, criando o valor (ELLUL, 1982a) ${ }^{16}$. A alienação, portanto, deixaria de ser

16 Vimos anteriormente como Marx relacionava meios de produção e força produtiva. Ellul, assim como Gorz, passam por cima da relação dialética que Marx apresentava para defender que as máquinas adquirem tamanha autonomia que, como diz Ellul, acaba produzindo valor. O próprio Marx dizia que as máquinas, sozinhas, apenas repassam seu valor para a mercadoria e não são capazes de gerar valor novo. A contradição que se apresenta e que Ellul ignora é um desdobramento da contradição entre capital e trabalho, sendo que o 
fruto de uma relação social e se tornaria efeito da conformação dos homens e mulheres a uma sociedade técnica. Em suma, na visão de Ellul, Marx não mais ajudava a ler a nova realidade, pois a técnica "tornou-se autônoma, e constitui um mundo devorador que obedece às suas próprias leis, renegando toda tradição" (ELLUL, 1968, p. 12).

Como vimos, Ivan Illich desenvolve uma argumentação muito semelhante e ambos defendiam que um aumento quantitativo levou a uma transformação qualitativa na técnica (ELLUL, 1968; ILLICH, 1975). O que os autores estavam tentando dizer é que a autonomização da técnica não dizia respeito apenas ao domínio da produção e das máquinas. Como diz Daniel Cérézuelle (2006), Ellul mostrou que o progresso técnico engendrou uma sociedade integrada que controla todos os setores da existência coletiva e individual, culminando na perda da autonomia e da liberdade.

Em alguns textos, Ellul aponta os fatores que deram origem à sociedade técnica. Em “A técnica e o desafio do século” (1968), a burguesia aparece como principal responsável pelo processo, ao mobilizar racionalmente as técnicas e multiplicá-las para assegurar e satisfazer seus interesses de classe. No século XIX, completa Ellul, Marx fez penetrar nas massas a ideia de que a técnica poderia ser libertadora desde que estivesse nas mãos do proletariado, o que fez de Marx responsável por disseminar definitivamente o elogio do progresso técnico por todas as camadas sociais - e, consequentemente, consolidar a sociedade técnica ${ }^{17}$. O ser humano tornou-se definitivamente um ser econômico, como preconizavam as teorias: inserese por inteiro em um mecanismo cujos valores são reduzidos ao dinheiro. E para que as pessoas consigam lidar com essa nova realidade, cria-se o mito revolucionário cujo principal fundador, nas palavras de Ellul, foi Marx.

Trata-se de um mito na medida em que o proletariado apenas quer tomar o lugar da burguesia, como ocorreu na URSS. E tanto para o proletário quanto para o burguês, o homem não passa de uma máquina de produzir e consumir. Assim, o que importa não são as necessidades dos homens, mas o escoamento de produtos; daí a propaganda, que vincula a felicidade e o sentido da vida ao consumo.

Já no livro “Illusion Politique” publicado em 1965 (1977), a explicação de classes apresentada dez anos antes no “A técnica...” é substituída por considerações históricas que

primeiro necessita do segundo para existir mas ao mesmo tempo nega-o em sua existência.

17 Esse argumento está presente até hoje no movimento do decrescimento e é mobilizado como principal razão para abrir mão do marxismo, seja como teoria seja como inspiração para a ação política. 
não localizam grupos sociais específicos como atores que erigiram uma nova sociedade. Ellul afirma que a Primeira Guerra Mundial teve papel fundamental na nova configuração social já que foi a primeira vez que todo o mundo esteve envolvido em um mesmo conflito. Uma guerra mundial implicava envolvimento total da sociedade: da produção de armamentos à produção de alimentos, passando pela organização das tarefas e trabalhos, tudo regido pela lei da eficácia (ELLUL, 1977). Ao mesmo tempo, a propaganda que surgiu como justificativa moral à guerra, se institucionalizou como nova forma de comunicação e se infiltrou nas subjetividades (ELLUL, 1967).

Ellul, contudo, parece estar menos preocupado com a origem do processo e mais com a “integração social” instituída pela técnica (ELLUL, 1968). Um dos elementos mais importantes para a integração social, segundo ele, foi a linguagem da eficácia: pretendendo-se universal (assim como a razão), a eficácia tornou-se o principal critério na escolha e elaboração das técnicas. Como a eficácia é uma linguagem que se pretende objetiva, só haveria um caminho a ser seguido por ser universal; duas pessoas que não falam a mesma língua estariam plenamente de acordo sobre a eficácia e a língua comum entre elas seria aquela "falada” pelas técnicas.

O diálogo com Marx aparece mais uma vez quando Ellul encaixa a economia nesse esquema explicativo. Marx teria acertado ao perceber que a economia capitalista não pode ser estacionária por sua natureza. O desenvolvimento técnico parece ser, assim, interessante: a linguagem da eficácia faz com que o desenvolvimento técnico das máquinas melhore e renove os produtos; a organização do trabalho incremente a produtividade e a técnica da propaganda contribua para acentuar necessidades e faz crescer o consumo. O investimento crescente em meios técnicos ocasiona, consequentemente, a concentração de capitais (tema que também é caro a Marx), já que os indivíduos sozinhos não conseguem financiá-los.

Marx não estaria totalmente errado em adotar uma perspectiva materialista cujos fundamentos são econômicos, argumenta Ellul, mas seria preciso mais do que isso em sua opinião. O primado da economia, na verdade, seria um desdobramento do primado da técnica, já que a primeira está submetida à segunda, e não a segunda à primeira (por isso Ellul diz que a economia deixou de ser uma doutrina e passou a ser uma técnica).

Erra-se quando se coloca a economia na base de todo o sistema marxista. É da técnica que todo o resto depende. Mas, a divisão [entre produção e distribuição], a oposição realizada por Marx deve ser revista, pois 
atualmente não é mais verdade que a técnica funcione apenas no domínio da produção. A repartição é consideravelmente modificada pelas técnicas. Não há mais um só domínio da vida econômica que seja independente da evolução técnica.

ELLUL, 1968, p. 153.

A concentração de capitais tem consequências políticas, pois o Estado é a única instituição que pode supervisionar o conjunto. Ao mesmo tempo, há todo um processo que faz com que a política pareça ocupar o principal papel nas sociedades atuais (ou seja, como se a política não fosse também submetida aos imperativos da técnica e da eficácia), defende Ellul (1977). Antes a política era assunto de pequenos grupos restritos, mas houve uma inserção da população no seio do processo político que fez com que a legitimidade do Estado passasse a repousar sobre a participação do povo (ou seja, um regime político só é legítimo se tiver algum tipo de respaldo da população que governa). Somou-se a isso (e à classe dirigente não obedece aos desejos pessoais), a expansão dos meios de comunicação e da instrução. A democracia aparecia, aos olhos de Ellul, como um sistema político comandado pela técnica, já que a própria organização da política é feita em nome da eficácia.

Em consonância às vozes de Charbonneau, Illich e Gorz, Ellul defendia que, assim como a economia e a política, outras relações sociais passam a existir na e pela técnica, como nas artes, literatura, comunicação, educação, esportes, trabalho, medicina e saúde. Contudo, Ellul dá um passo adiante e aponta uma esfera que, apesar de esboçada pelos demais, não é plenamente desenvolvida. A integração completa apresentada por Ellul se dá à medida que até o mais íntimo do sujeito converge com os imperativos da técnica, de modo que esses desejos sejam satisfeitos por produtos (que logo são substituídos). Consequentemente, a integração social diz respeito também à inexistência de um "fora” da sociedade. As dimensões privadas e íntimas da vida de uma pessoa são convocadas, por meio da técnica, a integrar o funcionamento técnico da sociedade e a existir sob a linguagem da eficácia. Isso significa que não é só o que é externo ao indivíduo que funciona pelo crivo da técnica. Toda sua existência é remodelada: do seu trabalho até seus desejos e necessidades.

Houve um momento, retoma Ellul, em que a vida humana era cindida, sendo uma parte "submetida às regras imperiosas e exteriores" e outra que era "reservada, de liberdades e de responsabilidade” (ELLUL, 1968, p. 421). A dilaceração é insuportável àquele que a vive e 
muitas foram as tentativas de corrigi-la, de modo que muitas vezes, o descompasso foi nomeado como patológico. O problema, continua Ellul, é que os meios utilizados para o restabelecimento da unidade do homem foram também técnicos. Consequentemente, a unidade do homem foi feita através de sua integração. “Aquilo que, na pessoa, ainda escapava” foi corrigido por psicólogos, mas também pela política que se tornou científica e por outras técnicas de humanização, que tornam imperceptíveis os inconvenientes de outras técnicas.

\section{1. 3. Da práxis à transformação}

Para esses quatro autores a luta de classes não mais aparecia como o móvel da história, afinal, o sistema que se impunha com cada vez mais força era impessoalizado, racional e técnico, se espalhou por todas as dimensões da vida social criando uma nova forma de alienação que concerne a todas, independentemente da ocupação, do nível sócio econômico, do país e do regime político. O modo de vida nessa nova configuração consequentemente se transforma e as pessoas não teriam mais nem a classe nem comunidades tradicionais como referência para a vida cotidiana.

De certa forma, a reflexão de cunho mais teórico que apresenta novas leituras e interpretações do mundo estava imbricada com a temática da ação. Por um lado, a sociedade totalizada, a grande metamorfose ou a contraprodutividade colocavam em questão os modos como as pessoas se organizam, como vivem, como interagem (modos que, segundo os autores, deixaram de ser determinados pelas relações de classe e passaram a ser orientados pelo sistema técnico). Por outro lado, a ação envolve também a transformação social. Castoriadis (1979) propôs uma revisão da obra de Marx ao dizer que este não tinha dado a devida atenção à dimensão política da luta de classes, como se a reprodução do capital fosse insensível às configurações sociais. Ellul, Charbonneau e Illich (Gorz em menor medida) estavam dizendo que a luta de classes não teria mais o papel de direcionar os rumos da sociedade porque agora a diferença de classes não era mais determinante na configuração das relações sociais.

Se havia algo a ser feito na visão dos quatro autores aqui em questão, seria preciso levar em consideração os novos mecanismos de restrição de liberdade. Eram "novos” mecanismos porque todas as esferas da vida haviam sido integradas (ou se tornaram meios de 
integração). Logo, essas esferas da vida ascendem para primeiro plano no que concerne à questão da ação política transformadora. Ellul, Charbonneau, Illich e Gorz não falavam em uma revolução em sentido abstrato, mas sim de uma transformação que fosse vivenciada no cotidiano, nas relações políticas, na produção, no consumo, nas relações sociais e na relação com a natureza. Uma vez que na visão dos autores, o trabalho desaparece como fonte de valor por conta das máquinas e quando as diferenças de classes são esterilizadas pela dominação imposta pela técnica, o interior da sociedade não é mais o espaço de luta, mas ao mesmo tempo, a luta deveria passar por esse interior na medida em que ela se dá por uma requalificação dos modos de vida. Vejamos como cada um dos autores desenvolve seus argumentos para entender melhor qual a relação entre "dentro" e "fora” que se coloca quando estão pensando sobre a transformação social.

Aqueles capazes de exercer algum tipo de transformação social efetiva em um contexto de integração eram, na perspectiva de Illich, os pobres dos países de terceiro mundo. Como vimos, Illich oscila, tratando a pobreza ora como um produto da contraprodutividade e do monopólio radical, ora como uma realidade preestabelecida sobre a qual a integração social se impôs, mas não conseguiu se realizar completamente. Quando afirma que os pobres têm um papel importante na condução de um novo caminho, seu argumento é que as populações marginalizadas ainda comportam brechas, espaços não dominados nos quais algumas necessidades verdadeiramente humanas ainda se mantêm.

Não bastaria, ou não seria verdadeiramente transformador, que os países subdesenvolvidos defendessem e promovessem o desenvolvimento técnico, argumentava Illich, pois isso implicaria orientar os esforços para resolver problemas colocados pela técnica. Ao contrário, a única solução seria colocar abaixo a estrutura que regula a relação entre o homem e a ferramenta, inverter as instituições industriais de modo que o novo sistema de produção esteja ligado a uma dimensão pessoal e comunitária. Uma ferramenta justa - por oposição à ferramenta que nos domina - "gera eficiência sem degradar a autonomia pessoal; não suscita escravos nem senhores; expande o campo de ação pessoal” (ILLICH, 2006a, p. 383). No lugar da produtividade industrial, deve estar a convivialidade, que consiste na "liberdade individual, realizada dentro do processo de produção, no seio de uma sociedade equipada com ferramentas eficazes” (ILLICH, 2006a, p. 384). 
Illich dedicou parte de sua obra panfletária (e de sua militância política) a sugestões práticas, sem que fique claro se essas sugestões são meios ou são o objeto da convivialidade: investimento em transporte coletivo, distribuição dos custos da educação especializada entre as empresas já que elas próprias deveriam formar sua mão de obra, independentemente da idade; redução do tempo diário de escola e extensão do aprendizado por 20 ou 30 anos para que a educação formal (gramática, matemática e técnicas) possa ser feita de maneira rápida e pontual, enquanto a sabedoria deve ser aprendida por toda a vida; consideração de outras formas de educação, como aquelas intermediadas por guerras de guerrilha ${ }^{18}$.

No lugar da medicina, Illich sugere uma reação autônoma e viva às mudanças de ambiente, ao crescimento, ao envelhecimento, às doenças, ao sofrimento e à morte. Uma vida autônoma é necessária para lidar bem com a dor, a doença e a morte. É preciso reintegrar o sofrimento à vida pois é isso que constitui a natureza humana (ILLICH, 1999). É preciso, então determinar politicamente limites para a ação humana. Do contrário, a medicina produz apenas uma sobrevivência anestesiada e solitária no hospital. Não se trata, ao mesmo tempo, do fim dos cuidados e da atenção especializada, nem a recusa total de tratamentos modernos e da criação de novos tratamentos. As ciências podem continuar a existir, já que oferecem conhecimentos interessantes para criar novas ferramentas para que as pessoas modelem seu meio ambiente imediato sem deixar de carregá-lo de sentido e signos, mas só podem fazê-lo sob a condição de serem aplicadas em aliança com saberes tradicionais, que não serão mais desqualificados.

Em suma, a convivialidade seria o efeito da redefinição social e política dos limites da produção técnica, um mundo da eficácia pós-industrial ${ }^{19}$ no qual o novo sistema de produção estivesse ligado a uma dimensão pessoal e comunitária, que o mundo não fosse homogeneizado por imposição da técnica - "onde a modalidade industrial de produção complementa a produção social sem a monopolizar" (ILLICH, 1975, p. 78).

Nesse sentido, Illich defende que socialismo só pode vir de bicicleta ${ }^{20}$, ou seja, uma sociedade outra só pode aparecer na medida em que a produção e a utilização de energia são socialmente determinadas e deixarem de esmagar as pessoas (ILLICH, 1975). Se levarmos em

18 Illich sempre citava Paulo Freire em suas reflexões sobre novas formas de educação desescolarizada.

19 Illich usa o termo pós-industrial porque recusa uma volta ao passado. Cf. (ILLICH, 2006a).

20 É importante levar em consideração que o termo "socialismo" só é usado por Illich como uma utopia no panfleto "Energia e Equidade". Em outros trabalho, a palavra sempre se refere ao socialismo real e hoje Illich é celebrado por ter proposto uma sociedade "convivial” (e jamais socialista). 
consideração os diversos textos de Illich sobre transportes, a bicicleta é uma ferramenta que sintetiza uma série de questões: o deslocamento pode ser feito por meio da energia humana, dá liberdade ao deslocamento, dispensa uma organização espacial por meio de ruas (que são feitas para atender os carros e não os desejos de deslocamento das pessoas). Hoje, muitos militantes do decrescimento acrescentariam um fator: a bicicleta permite um convívio humano e menos violento entre as pessoas, o que casa com a proposta de Illich.

É preciso que andemos todos juntos rumo a uma era de abundância, com a tarefa por nós próprios escolhida e a liberdade de seguirmos o ritmo de nossos corações. Reconheçamos que é essencial para o homem lutar pela sua própria realização, pela poesia e pelo recreio, uma vez que tenham sido satisfeitas as suas necessidades de alimentação, de vestuário e de abrigo - e que devemos escolher aquelas áreas de atividade que contribuam par o nosso próprio desenvolvimento e tenham significado para a nossa sociedade.

ILLICH, 1973f, p. 20.

Ellul acreditava que a revolução só existiria se as pessoas mudassem o seu interior. Somente uma "revolução da civilização" levaria a uma "revolução personalista", instaurando novos estilos de vida (TROUDE-CHASTENET, 1998). Pequenos grupos auto-organizados substituiriam pouco a pouco o Estado como unidade política, fortalecendo a participação política e limitando as possibilidades de guerra, já que funcionariam como contra-sociedades. Seriam como uma espécie de revolução imediata, pois poderia se espalhar para além das fronteiras - fazendo-as mesmo desaparecer. Ellul e Charbonneau chegaram a organizar acampamentos nos Pirineus nos anos 1930 para provar que um modelo de sociedade personalista (pequenos grupos em contato direto com a natureza) poderiam existir concretamente (TROUDE-CHASTENET, 2010).

Charbonneau concebia liberdade como autonomia para lidar com o próprio corpo, com as relações com outras pessoas e com a natureza e defendia que era preciso adequar as máquinas às necessidades humanas e não os humanos às máquinas. Logo, "progresso da liberdade" não se confundiria com "impessoalidade do poder" (CHARBONNEAU, 1973, p. 190). Entre os quatro autores aqui apresentados, Charbonneau é quem aborda a questão da natureza mais diretamente, já que preconizava uma relação profunda entre liberdade e natureza. Cérézuelle (2012) faz uma síntese interessante sobre a relação entre liberdade e natureza como contraposição ao mundo da grande transformação. O mundo natural e o mundo 
social impõem suas necessidades ao ser humano - o primeiro coloca as leis naturais e o segundo coloca a necessidade de eficácia, do dinheiro, das hierarquias. As necessidades não contêm em si uma orientação para a verdade, que seria, na visão de Charbonneau, as aspirações de justiça, beleza e bondade. A mediação entre a verdade e a necessidade cabem à vontade (volonté), que consiste na ação humana livre e não necessária. Isso significa que a liberdade não é apenas um produto final, mas a "mediação livre entre dois polos ontológicos em tensão" (CÉRÉZUELLE, 2012, p. 17).

Uma vez que os homens não estabelecem a relação entre esses dois polos, o primeiro se desenvolve até se tornar autônomo, ameaçando a natureza e a liberdade. Se, como vimos, o desenvolvimento das técnicas favorece a liberdade até um certo ponto, caberia à vontade controlar esse desenvolvimento para que ele não se convertesse em estruturas autônomas destrutivas. A liberdade para Charbonneau não consistia, portanto, em um ideal desencarnado e radical, mas sim naquilo que permite restituir à humanidade uma totalidade no tempo e no espaço, a qual foi totalmente destruída pelo desenvolvimento da técnica. Por essa razão, liberdade não seria a ausência de trabalho ou o gozo no lazer. Segundo Lamaud,

Charbonneau acentua o fato de que os humanos deverão trabalhar mais se quiserem se reapropriar de seus meios de existência e retomar a responsabilidade de suas necessidades. Esse trabalho manual ou intelectual poderá ser árduo e será destinado a substituir, em certa medida, o trabalho de máquinas inventadas para diminuir o tempo de trabalho ao aumentar sua eficácia.

LAMAUD, 2012, p. 82.

O trabalho transformador, contudo, não deveria ser compreendido por oposição ao lazer. Em “O Jardim de Babilónia” (1988), Charbonneau aborda muitas vezes esse tema para sugerir que o lazer, o campo e o descanso (em princípios opostos ao trabalho e à cidade) converteram-se em indústria culminando no controle absoluto da vida humana pela técnica, até mesmo nos momentos supostamente de liberdade. Essa transformação opera paralelamente à emergência do "sentimento da natureza", que seria a mistificação de uma natureza, reservada a determinados limites territoriais e a determinados usos. A questão é que a natureza, tal como é concebida na grande metamorfose, é uma natureza separada, mas na verdade tal separação é apenas uma maneira de garantir um domínio industrial sobre ela. Por essa razão, Charbonneau afirma que "na realidade, não existe provavelmente solução, no seio da sociedade industrial tal como nos é dada" (1988, p. 200). A real transformação só se 
realizaria mediante uma recusa à mistificação desse sentimento.

O primeiro dever de uma consciência e de uma defesa da natureza é portanto o de liquidar esses estereótipos do 'regresso à terra' ou dos idílios rousseauistas que nos impedem de amá-la pelo que ela é. A natureza não é boa, ela traz como nós a marca da imperfeição e da morte. Mas se a amarmos por ela própria - e não por algum reflexo antropomórfico dos nossos desejos - , então aprenderemos que é assim que ela nos dá a vida.

CHARBONNEAU, 1988, p. 214.

O que significa amar a natureza por ela própria? Para Charbonneau, trata-se de aceitar a contradição entre libertar-se $d a$ natureza (criando ferramentas para dominá-la) e limitar nosso poder sobre ela e ser livre no interior da natureza (CÉRÉZUELLE, 2012, p. 19). Nesse sentido, seria preciso reconhecer, por exemplo, as contradições entre natureza e indústria para se chegar a um equilíbrio no qual opostos convivem harmoniosamente. A agricultura não poderia ser reduzida à indústria de produção alimentícia e matérias-primas, mas deveria produzir alimentos ao mesmo tempo em que humaniza o espaço e oferece condições para a existência humana em meios naturais (protegendo contra inundações, erosões, perda da capacidade produtiva do solo) e garante paisagens diferentes (por oposição à homogeneização de todos os locais por meio do turismo, por exemplo). Segundo Cérézuelle,

a agroindústria é incapaz de assegurar corretamente as diversas funções de uma verdadeira agricultura; o fato de as paisagens se tornarem uniformes e feias são um sintoma de uma relação unidimensional e desequilibrada entre o homem e uma terra que ele não habita mas que se restringe a explorá-la

CÉRÉZUELLE, 2012, p. 20.

Charbonneau não chega a propor orientações práticas em seus textos, como fizera Illich, mas sempre buscou experimentar em sua vida cotidiana o equilíbrio. No texto de Michel Rodes (2012), que foi amigo de Charbonneau, sobre a militância e as reflexões práticas de Charbonneau, vemos que sua atuação pessoal é central para compreender seu projeto político, já que a forma como se engajava corresponde a novas modalidades de militância. Charbonneau foi um dos fundadores da Associação de Sociedades pelo Estudo, Proteção e Manejo da Natureza do Sudoeste (Association des Sociétés pour l'Étude, la Protection et l'Aménagement de la Nature dans le Sud-Ouest) em 1971, do Comitê Soussouéou em 1972 e do Comitê de Defesa da Costa Aquitânia; também estabeleceu relações com diversas outras associações pela França e com o Partido Socialista Unificado. Por meio do Comitê Soussouéou, engajou-se contra a construção de uma estação de esqui. 
Também se opôs a um complexo imobiliário em Bielle, em 1972. Nestas e em outras atividades de protestos, Ellul também esteve presente.

Segundo Rodes, Charbonneau enfrentava com um humor feroz seus colegas apoiadores do general Pétain, o exército e os responsáveis por promover transformações e destruir as florestas na região onde vivia. A imagem de um Charbonneau com um sorriso estampado no rosto no momento dos enfrentamentos diários (que são contados como “anedotas”) é bastante significativa de uma dimensão que se tornou valorizada nos meios de militância político-ecológica: o trágico é acompanhado de alegria, de uma perspectiva hedonista ${ }^{21}$.

Ainda segundo Rodes, Charbonneau e Ellul enfrentavam um paradoxo: por um lado, adotavam uma perspectiva humanista segundo a qual se proclama a liberdade absoluta do indivíduo; por outro, investigavam o determinismo técnico. Como se não conseguissem articular essas duas facetas de seu pensamento, os autores acabavam adotando uma posição aristocrática no sentido de figurarem como os poucos que conseguem ver os problemas do mundo enquanto os demais estão cegados por tais problemas. Embora essa questão não assuma um papel importante nos escritos de Charbonneau, é importante levá-la em consideração porque ela diz respeito diretamente ao caráter político de sua obra e a relação das teorias com a proposta de transformação social. A impressão de Rodes sobre a posição aristocrática de Charbonneau e Ellul evidencia uma questão teórico-política não resolvida por nenhum dos dois (e nem por Gorz ou Illich): como as pessoas tornam-se conscientes da grande metamorfose se ela subjuga até mesmo a dimensão subjetiva ${ }^{22}$

Charbonneau seria, entre os quatro autores, aquele que mais fazia aparecer a questão da natureza como um elemento fundamentalmente importante para compreender a grande metamorfose e a potencial transformação social. André Gorz também começa a se aproximar

21 Jean-Claude Besson-Girard escreveu o Decrescendo Cantabile (2005) cujo subtítulo é "pequeno manual para um decrescimento harmônico", no qual propõe que o decrescimento deve ter uma dimensão estética e erótica. A perspectiva adotada nesse livro é que o decrescimento pode levar ao belo e a uma sociedade desejável (no sentido de que as pessoas queiram vivê-la).

22 A questão não respondida não diz respeito à falta de orientações pragmáticas, afinal estas aparecem em grande quantidade. O problema que se coloca é de outra ordem: se a dominação da técnica é total, de onde surge a crítica? Há brechas da vida humana que não foram tecnicizadas? Como veremos adiante, Herbert Marcuse escreve no mesmo período e oferece uma resposta a essa questão uma vez que compreende os problemas em termos de deslocamento das contradições, de modo que ainda restam espaços para a grande recusa. 
dos movimentos ecologistas nos anos 1970, mas há uma diferença considerável sobre o lugar da natureza na concepção teórica e prática de ambos os autores. Gorz via na ecologia política um conjunto de teorias e práticas que poderiam nos libertar do domínio do capital. Já Charbonneau, assim como Ellul, dá mais atenção à liberdade do que à superação do capital, pois a liberdade não seria ameaçada apenas em sistemas capitalistas (CÉRÉZUELLE, 2006; LAMAUD, 2012).

A ecologia oferecia, na perspectiva de Gorz, a possibilidade de romper com o capitalismo e com a submissão da natureza, das necessidades e dos desejos humanos à técnica e à acumulação. Não era uma questão de divinizar a natureza, mas de estabelecê-la como limite externo da atividade humana (GORZ, 1978), já que a produção incessante, o consumo de massas e as instituições criadas para resguardar a acumulação de capital acabavam com a natureza e com a humanidade.

Mas se não há mais proletariado bem definido, e se todas as pessoas estão igualmente alienadas, a quem caberia promover uma transformação social? E o que seria essa transformação? Para Gorz, é justamente o fato de que o capital dominou todas as esferas sociais e decompôs o tecido social que enfraquece a ideologia burguesa e oferece um terreno fértil para a revolução. O movimento operário e o projeto de socialismo precisam ser redefinidos diante dessa situação na qual o a burguesia passa a estar do mesmo lado do proletariado. A tarefa do movimento operário é, portanto, construir uma força política nova e uma prática de massa - no sentido de união dos trabalhadores (técnicos, especialistas, mão de obra desqualificada, gestores, etc) - que permita superar a ordem vigente e implementar o autogoverno popular.

O movimento operário italiano era muito interessante do ponto de vista de Gorz porque abordava alguns motes para promover essa unificação do operariado industrial e colocar em xeque o capitalismo: defesa incondicional da integridade física dos trabalhadores (tema que leva a um questionamento do princípio de que o trabalho é uma mercadoria); defesa da integridade cultural dos trabalhadores (pois o trabalho subordinado ao capital impede o trabalhador de realizar suas capacidades reais), que envolve a luta pela igualdade de salários, a luta pela supressão das tarefas não qualificadas, repetitivas e embrutecedoras, a autogestão do trabalho e por fim a luta pela reconquista da escola, a qual deve favorecer o desenvolvimento pessoal e também profissional. 
Para que a luta aconteça, defendia Gorz, era necessário que cada setor da classe trabalhadora se reconhecesse como explorada e percebesse que a fragmentação do trabalho é uma ferramenta de controle do capital. Cada setor, como os técnicos e os intelectuais, só pode se emancipar juntamente com outros setores, e não buscando interesses corporativos. Além disso, os sindicatos devem superar a organização verticalizada, devem ser autogeridos com assembleias livres. A questão de se manter ou não uma instituição diante desse novo cenário é importante, pois diz respeito aos limites do sindicato: até que ponto ele deve manter uma forma que a burguesia aceite, e se essa forma for negada, não haverá um descontrole? Havendo uma revolução, o sindicato deve ser superado como movimento de massa e deve deixar de existir, mas em uma situação na qual a revolução não ocorreu, o sindicato deve negociar com as classes burguesas sem, no entanto, perder de vista a possibilidade da emergência de vanguardas que visem a superação total do capitalismo - vanguardas que podem mesmo estar em conflito com os sindicatos em períodos não revolucionários. Ou seja, os sindicatos podem negociar interesses corporativos, por exemplo, mas não podem deixar de se abrir à unificação diante de uma revolução (GORZ, 1978).

Era preciso levar em conta, também, que algumas propostas colocam o capitalismo em xeque mas não em risco de desaparecimento, como a proposta do Clube de Roma de crescimento zero ${ }^{23}$, que parecia a Gorz um engodo, porque apenas transferia os problemas ecológicos para países pobres. Em síntese, era preciso articular a luta ecológica com a crítica ao capitalismo para não sucumbir ao ecofascismo (GORZ, 1978), quando o capitalismo apenas muda a natureza do crescimento econômico.

Gorz não pretende sugerir ações específicas já que defende a autogestão, ou a autonomia da organização social, econômica e política. Mas como ele acredita que é preciso cuidar para que a autogestão não seja absorvida pelo capitalismo, algumas ideias lhe parecem interessantes para evitar esse fenômeno, como imóveis coletivos, com poucas máquinas, com ambientes comuns; uma produção de produtos que duram muito tempo, apenas poucos modelos que sejam suficientes para todos; máquinas fáceis de serem consertadas; jornada de trabalho de 20 horas. Complementarmente, deveriam haver ateliês em cada bairro para que as próprias pessoas construíssem para si mesmas aquilo que é supérfluo, evitando uma sociedade

23 Em 1972 foi produzido um relatório chamado Limits to Growth por um grupo de empresários industriais europeus sobre a inviabilidade ecológica de manutenção dos padrões de crescimento econômico e demográfico mundiais. Cf. (MEADOWS et al., 1973). 
uniformizada (GORZ, 1978). Essa utopia poderia se converter em um programa que corresponde à forma mais avançada do socialismo ${ }^{24}$.

A autogestão pressupõe necessariamente unidades econômicas e sociais pequenas para que suas atividades produtivas e a divisão de tarefas possam assegurar a uma mesma unidade territorial, diversidade de capacidades e talentos, riqueza das trocas humanas, possibilidade de ajustar parte da produção aos desejos e necessidades locais e um mínimo de autarquia local. Além disso, a autogestão requer métodos de produção utilizáveis e controláveis em nível local (quarteirão, bairro), geradores de autonomia econômica das coletividades locais, não destrutivos e compatíveis com o poder que produtores e consumidores exercem na produção.

Não se trata, na visão de Gorz, como também na de Illich, de um retorno ao passado, mas sim de restabelecer um equilíbrio entre produção institucional e autonomia de comunidades de base. A produção institucional seria planificada, voltada para a produção de bens duráveis e necessários, enquanto às comunidades de base caberia a produção do supérfluo. Essa produção seria viabilizada pelo aprendizado de coisas que não são ensinadas na escola - aqui a referência a Illich é bastante evidente embora Gorz não o explicite. Se a produção estiver limitada a produzir apenas o socialmente necessário, poderá haver redução de tempo de trabalho e expansão das atividades autogeridas e livres, como em ateliês e cooperativas, para a produção do supérfluo (GORZ, 1978, p. 121).

Colocando em prática essas formas de produção e organização social, a uniformidade do consumo e da vida desaparecerá e, em seu lugar, haverá uma diferenciação dos indivíduos de acordo com as atividades empregadas em seu tempo livre. Lamaud (2012) afirma que o problema de Gorz é considerar o trabalho como um fardo, do qual a humanidade precisa se libertar para poder gozar a real liberdade, enquanto Charbonneau teria defendido uma hipótese mais interessante, qual seja, de que o trabalho e o lazer devem deixar de ser opostos.

Qualquer que seja a linha ou o desdobramento argumentativo dos autores, fica evidente que havia uma preocupação de ordem prática, ou mais precisamente, de ordem da realização da transformação social. As teorias sobre a sociedade técnica foram desenhadas tendo em vista os modos de ação possíveis para superar o sistema vigente, e como o sistema

24 A auto-gestão, no entanto, não é uma panaceia, diz Gorz. Em uma situação de penúria material, se não houver reflexões constantes, a busca por maiores rendimentos materiais pode apenas reproduzir a separação entre trabalho e lazer, de modo que o primeiro continue sendo o "purgatório" para se atingir a liberdade no último (GORZ, 1978, p. 144). Em situações de pobreza, são necessárias intervenções políticas na economia com objetivos a longo prazo, o que requer decisões centralizadas. 
mudara, a ação política deveria mudar também. Vimos que não se fala em revolução e que o socialismo deixa de ser horizonte para Ellul, Charbonneau e Illich, ao passo que Gorz só aceita o termo se passado por uma revisão.

A entrada em cena da subjetividade e dos modos de vida acompanhou o "diagnóstico" do fim da luta de classes como motor da história. Sindicatos e partidos deixaram de fazer sentido como instrumentos de luta e foram cada vez mais perdendo espaço para outras formas de organização política (por exemplo, as associações das quais Charbonneau fez parte), marcadas pela reivindicação de outras formas de vida (sendo a própria ação política muitas vezes reduzida à adoção de modos alternativos de vida cotidiana). A ecologia aparecia aos autores como uma esperança por ser uma luta contra uma forma de sociedade, de economia e de política que afetava igualmente todos os indivíduos e que provocava transtornos até nos níveis mais íntimos da vida humana. Pela ecologia os autores vislumbravam novas formas de ação e novas formas de vida.

\section{2. A “nouvelle gauche” a a ecologia política}

Os trabalhos e as ideias de Charbonneau, Ellul, Illich e Gorz não eram os únicos a abordarem questões políticas nos anos 1960 e 70. Maio de 1968 foi como um catalisador, ou um momento auge daquilo que se convencionou chamar "nouvelle gauche”, ou nova esquerda francesa, composta por organizações maoístas, trotskistas, anarquistas, por novos movimentos sociais como o feminismo, as lutas anticolonialistas e a ecologia política. Segundo Keucheyan (2010), a "nova esquerda” apareceu em 1956 com a crise de Suez por um lado e com o esmagamento da insurreição de Budapeste pelos soviéticos e com o relatório de Kruschev sobre os crimes de Stalin, por outro. A novidade da esquerda consistia em manter a possibilidade de crítica social radical sem recair nas alternativas existentes naquele momento (socialismo real ou capitalismo) pois ambas eram associadas ao totalitarismo, uma vez que eram responsabilizados por massacres em massa e pela sujeição do corpo social ao Estado.

Arvon (1977) e Deléage (2010) definiram a “nova esquerda” em função da ênfase inédita nos modos de vida e na subjetividade. A importância dessas dimensões era decorrente, por um lado, do diagnóstico que o totalitarismo atingia até mesmo domínios subjetivos e privados, como seria a explicação de Ellul ou Charbonneau; por outro, esses domínios 
tornaram-se “campos de batalha” ou novos loci por meio da qual se poderia lutar contra o sistema totalizante que se impunha, como as propostas de Illich e Gorz. A politização da vida cotidiana estava, por sua vez, associada ao diagnóstico de falência do marxismo: tudo se passava como se, com o crescimento econômico e com a formação de novos grupos sociais que pareciam substituir as classes, não fizesse mais sentido pensar em um conflito no interior da sociedade, mas que havia novas modalidades de opressões. Esse era o mote das lutas feministas, das mobilizações anticolonialistas, das reivindicações homossexuais e da ecologia política.

A relação entre as mobilizações da nova esquerda e a produção teórica do período é apontada por uma série de autores. Luc Ferry e Alain Renaut (1988) dizem que os acontecimentos de 1968 jogaram luz sobre as formulações teóricas que até então não tinham visibilidade ou não tinham força política, como A História da Loucura e As Palavras e as Coisas de Michel Foucault (de 1961 e 1966, respectivamente). O ponto de convergência é a “concretude do poder”, a percepção das relações de poder e dominação nos níveis microscópicos da vida social (no caso de Foucault, na loucura, no corpo, nas prisões).

Outro elemento de convergência, na visão destes autores e que ainda é bastante controvertido, é o caráter anti-humanista daquilo que chamam de "pensamento 68”. O tema do fim da filosofia, o paradigma da genealogia, a dissolução da ideia de verdade e a historicização das categorias juntamente com o fim de universais, tudo isso era sistematizado por diferentes autores como Lévi-Strauss, Derrida, Bourdieu e Althusser em um embate contra o humanismo e contra a centralidade do sujeito para a compreensão das relações sociais $^{25}$. Ao mesmo tempo, os movimentos que tomaram as ruas, as fábricas e as universidades francesas defendiam a liberdade do indivíduo frente ao sistema esmagador. $\mathrm{O}$ argumento de Ferry e Renaut é que o pensamento dos anos 1960 levou à morte do sujeito por meio do questionamento filosófico do humanismo juntamente com o estímulo dos movimentos sociais ao indivíduo em detrimento do sujeito, à "dispersão em detrimento da concentração, [a]o temporário no lugar do voluntário” (FERRY; RENAUT, 1988, p. 90). Em poucas palavras, a morte do sujeito estaria ligada à perda do domínio de si e à incapacidade de

25 Apenas a título de exemplo, Lévi-Strauss escreveu na introdução das Mitológicas “A análise mítica não tem, nem pode ter por objeto mostrar como os homens pensam. [...] Não pretendemos, portanto, mostrar como os homens pensam nos mitos, mas como os mitos se pensam nos homens, e à sua revelia" (LÉVI-STRAUSS, 2004, p. 31). 
perceber o outro como sujeito, anulando a possibilidade de reconhecimento recíproco.

O maior problema dessa leitura, na visão da socióloga brasileira Irene Cardoso (1989) não é abordar a questão do anti-humanismo e da heteronomia ${ }^{26}$, afinal estes são temas do debate sobre a modernidade - Habermas, por exemplo, é um autor que se ocupou diretamente dessa temática ao longo de sua extensa obra. O erro consistiria em desconsiderar os pressupostos variados das distintas perspectivas filosóficas que rompem com a ideia de sujeito, já que nem todas as perspectivas que questionam o humanismo clássico e as filosofias da identidade recaem necessariamente na questão da heteronomia, explica Cardoso, como Lacan e Castoriadis. Não se trataria, então, de recusar a existência de uma voga que questiona a identidade, o humanismo e o sujeito, mas de verificar os rendimentos dos diferentes questionamentos sem considerá-los automaticamente como produtores de um pensamento da heteronomia e do individualismo.

O rendimento que podemos tirar do controverso livro de Luc Ferry e Alain Renaut é, portanto, menos a valoração da morte do sujeito e mais o panorama de um pensamento que associava o sentimento de mudança e de novidade ao questionamento de referências políticas e teóricas, como a noção de classe, de totalidade, de poder, de Estado, de revolução e de ação política.

Voltando às mobilizações sociais em curso nos anos 1960 e 1970 na França, seu aspecto fragmentado está associado a esse questionamento. Segundo Keucheyan (2010), Michel Foucault e Gilles Deleuze concentraram seus esforços para recusar a associação direta entre poder e Estado e apontar o aspecto micropolítico ou segmentário do poder, bem como para formular uma noção de luta sem passar pela contradição de classes. Do ponto de vista político, em uma sociedade do controle não seria revolucionário tomar o poder do Estado; também não se tratava mais de estabelecer bases nacionais ou internacionais para combater um inimigo comum - isso é bastante evidente nos circuitos da ecologia política, como veremos adiante. Se o poder se exerce descentradamente, como diziam não apenas Deleuze e Foucault, mas como vimos também em Illich, Charbonneau, Ellul e Gorz, seria preciso criar pequenos focos de luta para fazê-lo ruir. A totalidade social é, consequentemente, posta em questão tanto do ponto de vista das teorias (que convertem o múltiplo em ontologia do social) quanto da ação política (agir descentradamente para romper com a totalização ou totalitarismo

26 Decorrente do anti-humanismo, uma vez que, na leitura de Ferry e Renaut, não há mais a possibilidade de reconhecimento sem que haja humanismo. 
social).

Paralelamente à fragmentação no plano político, deu-se uma fragmentação no plano teórico, inclusive no interior do marxismo (cf. HOBSBAWM, 1991). Uma vez que o pensamento de esquerda descolou-se do marxismo da URSS e dos partidos, diversas correntes floresceram - estruturalismo, anarquismo libertário, catolicismo de esquerda, pósestruturalismo, situacionismo, etc. Não que antes outras correntes além do marxismo não existissem, mas neste momento a diversidade tornou-se uma questão de tal modo que a proliferação de perspectivas entrou para a história do pensamento francês como uma novidade. Em outras palavras, a proliferação de teorias e explicações era, ela própria, um modo de estabelecer uma ruptura com o pensamento dominante cujas bases (sociológicas e filosóficas) eram da ordem da universalidade.

Não é aleatório, portanto, que cada livro ou cada texto dedicado à história da ecologia política na França levante referências muito distintas a respeito do tema. Ellul, Illich, Gorz e Charbonneau são hoje associados ao decrescimento, mas também podem ser, junto ou separado de autores como Serge Moscovici, Antoine Waechter, Edward Goldsmith, Rachel Carl (uma das poucas, senão a única mulher amplamente reconhecida atualmente) e o próprio Clube de Roma, considerados importantes críticos que contribuíram com a elaboração de da ecologia política ${ }^{27}$; há ainda versões que da ecologia política que não remetem a qualquer elaboração propriamente teórica daquele momento (FILLIEULE, 2007).

Se a "nova esquerda” francesa escapa às homogeneizações, embora seja povoada de temas e questões transversais, parece ser interessante colocar, ao lado de Charbonneau, Ellul, Illich e Gorz, algumas mobilizações, manifestações e acontecimentos que hoje são considerados decisivos para a conversão da natureza em problema político (e esta seria a definição mínima de ecologia política que poderíamos dar). Essa aproximação faz cruzar a relação entre micro e macro, entre local e global, entre meios e fins, ou entre defesa da natureza e defesa da liberdade.

É comum que se localize a ecologia política como um dos braços da nova esquerda francesa. Esse tipo de interpretação histórica costuma ser paralela a versões que recortam a ecologia política do contexto no qual se encontrava e trata-a como um movimento de limites relativamente claros. Muitos trabalhos pretendem ainda mostrar como a ecologia política Charbonneau, Gorz e Illich, cf. CHARBONNEAU; RODES, 1979; JACOB, 1999. 
representou um avanço em direção a um mundo mais consciente e mais crítico de si mesmo. De diferentes formas, vários autores desenham uma história na qual a ecologia política é um campo do saber e da política que se mostra melhor e mais eficiente do que aquilo que se tinha até então - sobretudo o marxismo ${ }^{28}$.

Mais interessante, no entanto, parece ser pensar a ecologia política em outros termos, e não dentro de uma história linear em direção à razão, à consciência ou a visões mais esclarecidas. Localizá-la e apresentar as linhas que perpassavam uma diversidade de movimentos daquele momento é um procedimento interessante que nos permite enxergar a reformulação da noção de política e de relações sociais que se estende até hoje. O nascimento da ecologia política foi paralelo ao processo de reformulação da crítica e da militância política em diversos circuitos. Tanto as fronteiras podem ser borradas que hoje os militantes do decrescimento aproximam autores que nem sempre falavam de meio ambiente (como Ellul) a questões propriamente ecológicas.

Ao mesmo tempo, a mobilização ecológica não é apenas um desdobramento concreto de questões genéricas que se desenvolviam naquele momento. Como veremos a seguir, aquilo que veio a se configurar como problema ambiental tem um papel decisivo historicamente porque por meio dele se materializava o argumento da insuficiência da velha esquerda. Era como se um novo problema, decorrente do crescimento galopante da técnica e da indústria exigisse novas formas de mobilização social: a energia nuclear, por exemplo, podia causar danos para todas as pessoas, sem distinção de classe, raça e gênero, de modo que a luta contra a política energética francesa não correspondia mais às categorias mobilizadas em lutas proletárias, por exemplo.

A história do movimento ecológico é a história do encadeamento de questões “ambientais” e questões “políticas”, dando origem a novas formulações que não eram apenas sobre a natureza nem apenas sobre decisões políticas. No final do século XIX e começo do XX, apareceram, sobretudo na Inglaterra, na França e na Alemanha, sociedades protetoras de pássaros e outros animais caçados, sociedades em defesa das paisagens e de proteção da natureza. A natureza aparecia, neste momento, como algo que deveria ser “conservado”, mas a voga da conservação logo foi posta em segundo plano com o fim da Primeira Guerra Mundial e a premência da "reconstrução" da Europa (DALTON, 1994). Os grupos existentes se 28 Cf. (CANS, 2006; DELÉAGE, 2010; e VIOLA, 1996). Este último, além de defender o argumento da “conscientização” em nível global, estende suas considerações para a realidade brasileira. 
mantiveram em alguma medida, mas o período foi marcado pela decadência das motivações conservacionistas. A década de 1960 reabilitou a defesa da natureza sob a égide de questões políticas e sociais (BRAMWELL, 1989; CANS, 2006; DALTON, 1994). A tão antiga fuga da cidade ao campo, por exemplo, aparece agora sob o registro da recusa à sociedade do consumo.

Assim como Ellul, Illich, Gorz e Charbonneau mobilizam argumentos para justificar a elaboração de suas teorias, ou como outros autores elaboram explicações para a explosão de maio de 1968, os historiadores da ecologia política também atribuem causas para a retomada da questão ambiental na década de 1960. Russel Dalton (1994), por exemplo, diz que a ampliação das crises ambientais (como o naufrágio do petroleiro Torrey Canyon em 1967) evidenciou que os danos à natureza implicavam riscos para a humanidade, sendo logo associados às consequências dos rumos econômicos e políticos da França naquele momento. Mesmo que exista uma infinidade de causas a serem mobilizadas, o que importa é que, em todas elas, está em jogo a elaboração de um um corpo relativamente coeso de reflexões e questionamentos que constrói pontes e conexões entre natureza e cultura.

Bruno Latour (2004) faz considerações interessantes sobre a ecologia política nesse sentido: ao invés de identificar autores, ideias ou mobilizações sociais que deram origem e que orientaram o “campo” da ecologia política, é mais profícuo tratá-la como uma série de questionamentos, modos de pensar e de agir, espalhadas em alguns pontos e concentradas em outros (dando a impressão de constituírem um campo) que, em maior ou menor medida, foram responsáveis por borrar as fronteiras entre aquilo que parecia separado: a natureza de um lado e a política de outro. Consideremos, por exemplo, a enumeração de temas trabalhados pela ecologia política feita por Troude-Chastenet (1998) (que, segundo o autor, já estariam presentes nos trabalhos de Ellul nos anos $1950^{29}$ ): recusa da clivagem entre direita e esquerda, crítica do Estado e da burocracia, do produtivismo, da organização capitalista do trabalho, da primazia do econômico, do consumo, do centralismo e defesa da democracia direta, da escala local, da autogestão e autonomia nos planos político e econômico, da frugalidade e de um certo ascetismo, do meio ambiente e conservação da natureza.

Jean Jacob (1999), por sua vez, não concebe a ecologia política como um corpo coeso

29 Uma leitura alternativa defende que Ellul desenvolve esses mesmos argumentos apontados por TroudeChastenet com o objetivo de fazer uma crítica à humanidade que se distancia de Deus, e não de uma sociedade que se distancia da natureza (DUFOING, 2011). 
de movimentos em torno dessas questões. Em sua visão, a ecologia política era composta por nebulosas que se cruzavam em vários pontos comuns, dentre eles o principal era o projeto revolucionário pós-marxista ${ }^{30}$. Algumas linhagens criticavam a sociedade moderna em nome dos velhos tempos; outras acusavam a busca do lucro desenfreado por ser indiferente aos equilíbrios ecológicos; a ecologia científica incorporou questões de outras ciências, como a demografia, a agricultura, a economia (DELÉAGE, 1991). Enquanto isso, o antigo sentimento de retorno à terra e as preocupações sobre o esgotamento da natureza (proteção de espaços "naturais" e de certos animais, sobretudo pássaros) transformaram-se em "preocupações em torno do meio ambiente, do consumo, da poluição e dos domínios que ultrapassam largamente o conhecimento do meio natural” (CANS, 2006, p. 86 grifo meu) ${ }^{31}$.

A conjugação entre natureza e política foi acompanhada pela reconfiguração das práticas de militância política. Segundo Cans, “apropriando-se do furor do esquerdismo, das liberdades do anarquismo e da energia das manifestações, os ecologistas aprenderam a desafiar o poder, a fazer barulho para defender suas convicções e a ignorar o sarcasmo de espectadores não engajados” (2006, p. 110). O mesmo autor defende que, apesar de existirem iniciativas anteriores a Maio de 68, foram as manifestações desse momento que trouxeram à tona a possibilidade de conjugar métodos de contestação e protesto às reivindicações dos defensores de animais, de pesquisadores, de cientistas e de outros atores que antes não saíam às ruas.

Embora possa se questionar a data precisa da convergência entre ecologia política e formas de contestação, é interessante perceber que essa conjugação diz respeito à emergência de novos atores que não acionam uma identidade de classe propriamente dita no momento da mobilização, ou que não colocam a questão da classe como fundamental para sua reivindicação. Cans menciona o caso de Philippe Lebreton, um biólogo que não era engajado, até que, em 1967, cria um comitê para discutir a gestão dos rios em Lyon e depois de 1968 “o filho de bons pais, amante da natureza, se tornou contestatário” (CANS, 2006, p. 121).

Ao mesmo tempo, a ecologia política não é uma causa unívoca que substituiu a

30 Outros autores, como Dufoing (2011) e Ekovich (1996) também acentuam como uma das principais características da ecologia política daquele momento o rompimento com o marxismo.

31 A revista Écologie \& Politique, em circulação na França desde, publicou uma série de dossiês voltados para a atualização da ecologia política e são recorrente as tentativas de diferenciar a ecologia política do "mero amor à natureza" (ZIN, 2010). Isso significa que existem dois pontos ainda recorrentes entre aqueles que pretendem circunscrever a ecologia política: a relação com o marxismo e a diferenciação da defesa da natureza. 
identidade de classes, sendo que a articulação entre política e natureza podia se fazer de várias formas. Os autores apresentados anteriormente, quando defendem um processo de totalização social, estavam colocando uma série de problemas lado a lado, como a exploração da natureza ser um efeito do mesmo fenômeno social que gera a perda de liberdade. A ecologia política, enquanto conjunto de mobilizações sociais fez o mesmo: ao estabelecer conexões entre problemas ambientais e razões políticas, econômicas e sociais, a defesa da natureza passava por um questionamento das relações sociais e vice-versa.

A partir de 1968 foram criadas diversas associações de cientistas e universitários para estudar e defender o meio ambiente. Dentro das universidades e escolas, as preocupações ecológicas começam a se formalizar como disciplinas e até mesmo como curso. A imprensa começou a publicar, no final dos anos 1960, dossiês, reportagens e reflexões sobre meio ambiente e ecologia, com base em informações obtidas por especialistas, professores universitários e pesquisadores, bem a como noticiar protestos e fazer denúncias. Por parte das editoras, começaram a publicar livros relacionados ao combate ecológico. O livro Le Jardin de Babylon, de Charbonneau, só consegue ser publicado em 1969 apesar de ter sido escrito muitos anos antes. Segundo Cans (2006), enquanto alguns livros falavam sobre maneiras de viver melhor, outros relacionavam o retorno à natureza com a ilusão do progresso, com o reencantamento do mundo. Além disso, publicações "ecológicas" começaram a aparecer, como o jornal La Gueule Ouverte e o Le Sauvage.

A ecologia política também envolve a questão da militância e dos métodos de manifestação fora de ambientes institucionais. Muitas pessoas saíram de grandes cidades para se instalar no interior, criar ovelhas e cultivar produtos orgânicos (cf. BESSON-GIRARD, 2005), algumas sem mesmo ter participado de outros tipos de manifestação coletiva. Outra forma de militância era participar de associações e protestos. Em 1969, a Força Aérea Francesa precisava criar uma torre de controle e o local escolhido foi uma floresta nos limites de Bouches-du-Rhône. A imprensa logo protestou quando foi noticiada a construção de uma estrada (no meio da floresta) para se chegar ao local escolhido, e determinado dia, o caminhão e a escavadeira que estavam estacionadas no canteiro de obras foram explodidos. A obra foi suspensa pelo então presidente Charles Pompidou e considera-se que a explosão tenha exercido um papel importante nessa decisão.

Outro protesto ocorreu em 1972, em oposição à construção de uma pista para 
automóveis na margem esquerda do rio Sena, quando foi organizada uma grande manifestação de bicicletas. Brice Lalonde, que viria a ser ministro do meio ambiente na França entre 1988 a 1992 (no governo de François Mitterrand) esteve presente e, em 1973, seguiu com mais quatro homens em um pequeno barco de madeira da Nova Zelândia à Polinésia Francesa, representando a associação Amis de La Terre, em oposição à política de energia nuclear iniciada por Pompidou. Segundo Roger Cans, Brice Lalonde ilustrava a nova modalidade de militância, que fazia da vida cotidiana uma arena de luta:

Esse filho da grande burguesia, que cresceu no conforte e na liberdade, desconfia tanto do dogmatismo marxista quanto da retórica da esquerda. O que ele quer não é transformar o regime nem bagunçar a sociedade, mas sim tornar a vida cotidiana mais sustentável, agradável, sobretudo nas cidades que estão sendo devoradas por carros.

CANS, 2006, p. 135.

O florescimento da ecologia política como forma ou tema de mobilização foi acompanhada ainda pela institucionalização da questão ambiental. No interior do governo francês, o meio ambiente também passou a figurar depois de 1968. A criação de um Ministério do Meio Ambiente na França, em 1971 envolveu a reorganização de outros ministérios: o da Indústria perdeu as prerrogativas de controle e o da Agricultura perdeu a tutela sobre a pesca, a caça e a água. Pompidou, na visão de Cans, era favorável à industrialização, mas deu espaço a um ministério verde porque era afeito à modernidade e considerava o meio ambiente um tema do futuro.

Embora a história da ecologia política nem sempre faça referência explícita ao marxismo como um inimigo ou como uma posição teórico política naquele momento aparecia como algo que deveria ser superado, seu questionamento estava presente, mesmo que nas entrelinhas da formulação da "novidade" dos protestos, dos "novos" questionamentos chamados “imateriais" e na emergência de "novos atores” políticos, afinal esse era um tema caro à elaboração daquilo que se convencionou chamar de nova esquerda - a ecologia política incluída. Diante de tantas críticas, teria o marxismo, então, desaparecido? Definitivamente não foi isso que ocorreu, mas sim houve uma reformulação da herança de Marx, mas à diferença do que se deu em momentos históricos prévios, o que a "nova esquerda” fez foi afirmar um terreno da crítica social cujo primado era a descentralização. A explosão de correntes de esquerda, sobretudo em maio de 1968, não foi apenas um efeito ideológico de 
uma transformação das condições materiais (como o enriquecimento da população e a impossibilidade aparente de se falar em contradição de classes), mas foi um elemento fundamental para a consolidação de uma crítica social fragmentada e descentralizada.

A ecologia política sem cânones, os muitos militantes que se multiplicaram em seus lugares com seus estilos de vida questionadores (como Brice Lalonde e tantos outros aqui não apresentados), o slogan "pensar global, agir local” que circulava em diferentes versões, tudo isso eram maneiras de negar um corpo unívoco de conhecimentos e práticas sociais. Se hoje nos deparamos com uma vasta literatura que apresenta a nova esquerda como um mosaico, como a explosão de perspectivas distintas sobre os problemas do mundo (bem como diversas maneiras de entendê-los e combatê-los), é preciso que se tenha em vista que a fragmentação era uma recusa intencional, mesmo que não necessariamente explicitada, de formas de mobilização política que passavam por grandes coletivos supostamente homogeneizadores e autoritários (como os partidos comunistas de todo o mundo), sendo o marxismo identificado como um dos elementos chaves na construção da esquerda tradicional.

A literatura que louva a nova esquerda em geral e a ecologia política em particular acaba apresentando um quadro como se o marxismo tivesse sido completamente superado e por isso tivesse desaparecido, ao menos naquele momento, mas o marxismo continua a aparecer ora como referência, ora como contraponto. Parece haver atualmente um conflito análogo no interior do decrescimento: de um lado, é uma mobilização aberta e composta por uma infinidade de coletivos; de outro, o jornal La Décroissance corre sempre o risco de ficar fora da “nebulosa” porque é considerado pouco condizente com a própria ideia de que não há distinção hierárquica entre tais coletivos. É importante ter em vista essa ambiguidade que existe no seio do argumento da multiplicidade de narrativas que equivalem-se. Tudo se passa nas estratégias descentradas e não-hierarquizadas de descrição do mundo ou de experiência social como se qualquer coisa pudesse ser disposta ao lado de qualquer outra, em uma extensa rede, sem que os conflitos acarretassem na anulação de certos pontos dessa rede em favor de outros que passam a ser dominantes.

O avesso dessa imagem é que o próprio mapeamento de uma esquerda fragmentada é responsável pelo apagamento do marxismo que, na verdade, continuou a existir e, mais do que isso, aparece como um espectro para essa nova esquerda que se constrói a todo momento por referência a ele. A crise do marxismo (ou seja, sua insuficiência) não é apenas uma causa da 
explosão da ecologia política que lhe colocou questões, mas é também sua consequência. Como diz Hobsbawm (1991), o marxismo não entrou em crise, mas sim deixou de ter uma linha predominante. A perda do lugar de referência corresponde à fragmentação da esquerda que, por isso, se assumiu como “nova”.

Se o próprio marxismo, que é insistentemente silenciado, remodelou-se a partir do modelo da ausência de centralidade, é interessante verificar como isso aconteceu, uma vez que confirma a emergência de uma nova modalidade de crítica social (da qual a "nova esquerda” é uma possibilidade, assim como a “ecologia política”).

\section{3. Marxismo fragmentado}

As insistentes referências ao marxismo, mesmo que fosse para silenciá-lo, explicitam a predominância do marxismo nos períodos precedentes na esquerda francesa. Segundo Eric Hobsbawm (1991), a hegemonia devia-se, em primeiro lugar, à identificação entre marxismo e movimentos políticos fortes, que ofereciam uma ameaça real ao status quo em nível internacional. Havia também uma identificação entre crítica social e marxismo, de modo que qualquer questionamento ao socialismo redundou em uma crítica de Marx. Por fim, o marxismo sempre atraiu intelectuais de alto nível, conferindo-lhe não só status mas também e sobretudo, um arcabouço teórico consistente.

Ainda na visão de Hobsbawm, o marxismo continuou forte depois dos anos 1950, mas passou por transformações para se adaptar à nova conjuntura que se estabelecia com o fim da Segunda Guerra Mundial, a qual foi usada como argumento por Gorz, Illich, Charbonneau e Ellul, bem como muito ecologistas políticos, para justificar a insuficiência ou falência do marxismo. Em primeiro lugar, nos anos 1950 os partidos com base de massas estavam se enfraquecendo na medida em que a classe dos operários manuais (núcleo dos movimentos de trabalhadores) perdia terreno face aos outros setores da população trabalhadora. Em segundo lugar, havia uma perda de coerência interna à classe, ocasionada pela melhoria da qualidade de vida da classe operária, pela pressão dos meios de comunicação em massa e pela massificação da educação (que propiciava melhores salários e especialização aos filhos dos proletários). Em terceiro, os trabalhadores perdiam a confiança no movimento socialista, sobretudo diante das denúncias ao regime soviético, e os partidos deixaram de ser o norte da 
produção teórica e política do marxismo.

Houve ainda uma transformação no interior do marxismo: a partir da segunda metade dos anos 1920, houve um engessamento no interior dos partidos, só restando duas possibilidades: ou posicionar-se contra ou a favor aos partidos operários (KEUCHEYAN, 2010). As tensões que se colocaram a partir de então foram marcadas pela obliteração das relações entre intelectuais e dirigentes de organizações operárias (com algumas exceções como Louis Althusser e Georg Lukacs), já que estava em curso um processo de profissionalização da atividade intelectual ${ }^{32}$, ou seja, aqueles que mantiveram uma posição marxista, mas que não concordavam com as orientações teóricas do partido encontravam lugar nas universidades como intelectuais. De outro lado, as direções dos partidos comunistas desconfiavam dos intelectuais. A partir dos anos 1950, com o enfraquecimento dos partidos, o crescimento de organizações profissionais não proletárias (profissionais da saúde, da educação, da seguridade social), o apoio cada vez maior dos intelectuais e com o aumento de instituições de ensino superior, acentuou-se o processo que já estava em curso e o marxismo passou a ser uma questão propriamente intelectual (HOBSBAWM, 1991) e filosófica (ANDERSON, 2004). Como diz Hobsbawm, o marxismo passou a produzir-se via uma linguagem esotérica, teórica e os debates que atraíram maior atenção foram aqueles ligados a filósofos, como Georg Lukács, Jean-Paul Sartre e Louis Althusser.

Otto Kallscheuer (1989) refuta a tese de Perry Anderson sobre a cisão entre teoria e prática no seio do marxismo ao sugerir que o desenvolvimento filosófico faz referência ao contexto dos processos sociais e políticos no qual se insere, ou seja, se há uma abordagem de caráter mais teórico, em nenhum momento ela se afasta da realidade empírica. Althusser, que foi muito criticado por elaborar um marxismo científico, dizia que a ênfase nos problemas teóricos oferecia uma contribuição concreta para a prática revolucionária:

Se voltamos a Marx e colocamos conscientemente, na conjuntura atual, a ênfase sobre os problemas teóricos, e, antes de tudo, sobre o "elo decisivo" da teoria marxista, a saber a "filosofia", é para defender a teoria marxista das tendências do revisionismo teórico que a ameaçam; é para desprender e precisar o domínio onde a teoria marxista deve a qualquer preço se desenvolver para produzir os conhecimentos de que os partidos revolucionários precisam urgentemente para confrontar os problemas

32 Perry Anderson (2004) também aponta o caráter intelectual como uma das principais características do marxismo ocidental (aquele que se erigiu em contraposição ao marxismo soviético). 
políticos cruciais do nosso presente e do nosso futuro. Não pode haver nesse ponto nenhum equívoco.

ALTHUSSER, 1999, p. 14.

Outro contraponto à clássica leitura de Perry Anderson sobre a separação entre teoria e práxis no marxismo ocidental é oferecida por Hobsbawm à medida que este aponta para a explosão de um pluralismo no interior do marxismo nos anos 1960. O intelectual marxista foi, na verdade, um efeito desse fenômeno, e não a causa da redução do marxismo à esfera intelectual. Uma vez que a ortodoxia internacional foi substituída pela fragmentação do movimento comunista internacional, o resultado foram ortodoxias muitas vezes rivais. Incertezas sobre estratégias dos partidos fizeram com que aparecessem diferentes interpretações dentro dos próprios partidos, ao passo que movimentos e partidos radicais tentavam se aproximar do marxismo, produzindo interpretações que uniam marxismo a teorias não convencionais (católicas, islâmicas, etc).

Nesse contexto, não havia mais, sequer, um consenso difuso (nacional ou internacional) do que significava ter uma filiação marxista, e daí a importância que ganhou a figura do intelectual: as teorias produzidas por ele deixaram de se associar a coletivos, grupos ou partidos e passaram a ser identificadas imediatamente com a pessoa, fazendo do marxista uma “personalidade”. Pessoas influentes, livres, que não representavam o partido tornam-se referência (HOBSBAWM, 1991).

Ainda segundo Hobsbawm, o pluralismo que se desenvolveu depois dos anos 1950 foi pontilhado por versões errôneas do marxismo, mas mais importante do que identificar erros seria verificar que a profusão de marxistas era uma expressão da "mais profunda fratura até aqui registrada na continuidade da tradição intelectual marxista” (HOBSBAWM, 1991, p. 55): a nova esquerda foi marcada por uma fermentação política e intelectual que recusava as orientações do Partido Comunista Francês em particular e do movimento comunista internacional em geral.

Se a proliferação de perspectivas foi considerada inédita e constitutiva da nova esquerda, e se pode ser interpretada como uma característica do período (por oposição à hegemonia da visão marxista), o “matagal” marxista (como diz Hobsbawn) também é parte da reconfiguração de uma esquerda que cujo eixo político passava por fora dos mecanismos políticos tradicionais e da recusa de uma linha centralizadora e organizadora da esquerda 
como um todo. A perda de referências e de eixos centrais é tão expressiva que Hobsbawm, quando propôs uma retomada dos rumos da esquerda francesa, defendia a retomada de limites "dentro dos quais o debate e a divergência podem razoavelmente reivindicar uma filiação a Marx" (HOBSBAWM, 1991, p. 55). Isso significa que mesmo no interior do marxismo a recusa a uma orientação unívoca passou a vigorar ${ }^{33}$.

\section{4. Do “novo" à nebulosa}

Novas realidades demandam novas explicações e novas formas de mobilização. A "nova esquerda” e os "novos movimentos sociais" eram novos porque propunham uma alternativa às velhas contribuições teóricas e velhas mobilizações sociais, embora em alguma medida sempre usassem referências destas. A velharia, por sua vez, era tudo o que se associava ao marxismo. No novo padrão de sociedade, o capitalismo baseado na indústria teria sido substituído por uma sociedade pós-industrial, na qual a técnica em sentido amplo ocupou o lugar da dominação. "Técnica e cultura passariam a interpenetrar-se, as distinções entre mundo público e privado teriam se nublado, fazendo com que os conflitos, antes restritos ao plano econômico, avançassem para a vida privada (família, educação, sexo) e ganhassem dimensões simbólicas” (ALONSO, 2009, p. 60).

Ellul, Charbonneau, Illich e Gorz são hoje considerados precursores do decrescimento por muitos teóricos porque teriam problematizado conceitualmente o mundo, oferecendo elementos para a elaboração da crítica ao crescimento econômico. Há, entretanto, que se levar em conta uma outra possibilidade de associação entre esses dois momentos, que não aparece nas falas e textos dos apoiadores do decrescimento hoje. Trata-se da relação entre o conteúdo da crítica que faziam e a forma nebulosa que o movimento assume hoje. Ao apresentarem os problemas em sua concretude e abordarem a totalização social da técnica, as contraprodutividades e a grande metamorfose, esses autores foram responsáveis por construir um corpus de conhecimento cujo centro não era a crítica ao crescimento nem a questão

33 Mesmo com a fragmentação do marxismo que teve início nos anos 1960, podemos identificar um tema que perpassa a obra e as reflexões teórico-metodológicas de autores diversos: a questão da ideologia. Herbert Marcuse (1969), Guy Debord (1995) e Luis Althusser (1996) desenvolveram, a partir de perspectivas bastante diversas, uma problematização da ideologia; mas ao que os aproxima é não apenas o tema mas a proposta de não conceber a ideologia como plano separado e invertido das relações materiais de produção. Para uma leitura que aproxima esses diferentes autores, cf. ZIZEK, 1996a. 
ecológica, mas sim a crítica a um mundo supostamente novo que se constituía por formas de dominação distintas de tudo o que já se havia verificado. A vida cotidiana e dimensões do privado passaram para o centro de suas análises; o lazer, o turismo, o trânsito, as relações de trabalho concretas (e não pensadas abstratamente como relações de classe), a propaganda e a subjetividade estão entre os temas desses autores, assim como são hoje questões da nebulosa do decrescimento.

Metodologicamente, esses quatro autores e os movimentos buscaram novas maneiras de conciliar, teórica e politicamente, o todo e suas partes. O slogan "pensar global, agir local” em voga entre os movimentos ecológicos corresponde às formulações teóricas de Charbonneau, Ellul, Illich e Gorz. Pensar global não é apenas pensar em problemas sociais de grande escala, mas pensar nos problemas que assumem dimensões globais, que não se restringem mais à classe operária ou aos pobres. Pensar global é compreender a alienação como generalizada, como nova forma de opressão que não corresponde a setores sociais particulares. Os problemas ambientais são também novos porque são formulados como um efeito global de novos problemas generalizados. Agir local não é agir individualmente, mas agir lá onde o problema global de domínio técnico se manifesta: na saúde, nos corpos, na sexualidade, na natureza, na alimentação. Por isso Gorz dizia que o movimento ecologista era importante para transformar o capitalismo. As relações entre os partidos comunistas, por exemplo, não se encaixavam nas diretivas implícitas no “pensar global, agir local”.

Tudo se passa como se Charbonneau, Illich, Ellul e Gorz tivessem sido pioneiros na problematização da sociedade em uma nova chave. Mas o ponto é que o diagnóstico de uma "nova realidade" totalizante e exterior (donde toda a discussão sobre heteronomia), de uma pura forma sem qualquer conteúdo que determina as relações sociais e as relações entre humanidade e natureza, tudo isso deu margem para a conjugação da crítica ao crescimento com a forma nebulosa de organização social e política que veremos a seguir.

A ecologia política, as teses desses autores e todo o corpo de conhecimentos e práticas instauradas no fim dos anos 1960 negavam as contradições no interior da sociedade em nome de um "problema maior" - dentre os quais o meio ambiente. Era como se não fizesse mais sentido pensar as lutas no "interior" da sociedade, e sim todas as pessoas tivessem que se unir para lutar por algo que se tornou maior e exterior a que elas ${ }^{34}$, sendo a impessoalidade do sociedade deve se unir, passando por cima das diferenças para conseguir superá-lo (cf. ACCIOLY, 2012). 
poder um argumento bastante significativo dessa argumentação. Tudo aquilo que aparecia como novidade (nova sociedade, novas teorias, novos movimentos sociais, novas formas de luta, novas formas de alienação) era uma forma de expulsar a fratura social para fora da sociedade ao mesmo tempo em que esta se reconstitui.

O corpo de conhecimentos e práticas críticas que explodiram nos anos 1960 e 70 na França foram responsáveis por elaborar uma compreensão e formas de ação no mundo segundo as quais, no “interior” da sociedade, não se verificam mais as contradições sociais ${ }^{35}$. O que configura então esse interior? Os micropoderes difusos, de um lado, e as microtransformações de outro. Diversas correntes dessa nova esquerda interpretaram o mundo como se não houvesse um desenvolvimento dialético da forma de capitalismo precedente para aquela em operação no pós-guerra ${ }^{36}$ e como se as contradições tivessem deixado de ser o fundamento da existência social.

Anos mais tarde, uma nova onda de mobilizações sociais retomou a agenda, as formas, as estratégias e as questões colocadas nos anos 1960 pela nova esquerda. Sob a luz da globalização e do neoliberalismo, essas novas mobilizações tomaram como ponto de partida noções de sociedade que não eram marcadas por contradições, mas por diferenças. O slogan “um outro mundo é possível” que circulou nos anos 2000 a partir dos Fóruns Sociais Mundiais apontava para o problema que a globalização trazia: o mundo todo parecia ter se curvado definitivamente ao capitalismo e não havia mais nem mesmo espaços geograficamente isolados do domínio do capital $^{37}$. Foi trazido à tona, portanto, o problema da desaparição do "outro" do social e a profusão de maneiras encontradas para lidar com essa questão é que passavam pela atualização da nova esquerda.

A atualização estendeu o debate sobre a passagem da parte ao todo, reformulando a relação entre universal e particular por meio do vocabulário das redes e das conexões, como será visto no próximo capítulo. Com vistas a não recair em coletivos e ações atomizadas, mas também não suplantar as diferenças, busca-se maneiras de garantir uma ação coletiva que não

35 No Terceiro Capítulo, essa discussão voltará à luz das contribuições de Herbert Marcuse.

36 No terceiro livro d'O Capital, Marx (1986) mostra que o capitalismo financeiro é um desdobramento mas ao mesmo tempo já esteve sempre contido na relação mais elementar m-d-m, aquela apresentada logo no primeiro capítulo do primeiro livro. Isso significa que o desenvolvimento do capitalismo não é efeito de rupturas, mas de desdobramentos dialéticos de relações contraditórias existentes nas relações capitalistas aparentemente mais simplificadas, como a troca de mercadorias.

37 Uma vasta literatura foi produzida durante os anos 1980 e 1990 sobre o fim da história, quando se dizia que não havia mais horizonte fora do capitalismo cf. FUKUYAMA, 1992. 
suplante a diversidade. A seguir, veremos como o movimento do decrescimento cria formas de relação que pretendem dar conta dessa dupla tarefa. 


\section{Capítulo 2. Decrescimento em nebulosa}

Pour changer, échangeons...

Revista Silence

A revista Silence, publicação bastante difundida nos circuitos do decrescimento, lançou um dossiê especial chamado "L'écologie en 600 dates”, no qual uma miríade de histórias divergentes é apresentada como um mosaico de referências. A proposta era levantar a diversidade de referências, mesmo que elas em nada tenham a ver umas com as outras, porque seria impossível adotar um ponto de vista objetivo sobre a construção de um "novo imaginário” (L’ÉQUIPE DE LA REVUE SILENCE, 2012, p. 3). Um caderno especial de 2006, anexado ao jornal La Décroissance que é considerado por muitos o oposto da revista Silence, dizia que o decrescimento não podia ser apresentado como algo que tem uma história linear: “O decrescimento é um pensamento vivo em perpétua evolução. A questão essencial não é a paternidade do termo, mas o que se faz com este, e qual o sentido que o decrescimento assume progressivamente” (“Historique du mot”, 2006, p. 16).

Charbonneau, Ellul, Illich e Gorz aparecem nestes textos ao lado da invenção da acupuntura, da permacultura , do livro “A sociedade do espetáculo” de Guy Debord ou do “Pensamento selvagem” de Lévi-Strauss, e de tantos outros eventos ocorridos em momentos históricos distintos. A edição especial da revista Silence, por exemplo, não requer uma leitura do começo ao fim, podendo ser aberta aleatoriamente e lida sem que a leitora ou o leitor tenham que se preocupar com as páginas precedentes e subsequentes, afinal a própria diagramação e o tamanho dos artigos permite esse tipo de procedimento. É como se houvesse uma recusa em tratar o decrescimento como um movimento cuja história pode ser apresentada como sucessão de fatos.

Decrescimento é a palavra que faz referência a um conjunto de mobilizações sociopolítico-ecológicas que criticam o crescimento econômico e os padrões de consumo nos países de capitalismo avançado. Essas críticas assumem as formas mais diversas como que em oposição a uma centralização do movimento. Um dos meios encontrados para nomear essa 
mobilização que apesar de ter um nome é uma variedade de associações, coletivos e pontos de vista foi considerar o decrescimento como uma "nebulosa”. Os livros escritos na França com a finalidade de apresentar o decrescimento de maneira abrangente (e não apenas como as teorias de Serge Latouche, por exemplo) usam a palavra "nebulosa” para explicar porque precisam usar vários capítulos, alguns para as teorias e outros para os pequenos coletivos espalhados na França (cf. BAYON; FLIPO; SCHNEIDER, 2010; DUVERGER, 2011). É comum também que os próprios militantes evoquem a "nebulosa” para apresentar o movimento, como forma de dizer que existem alguns sentidos compartilhados sem que haja algum (ou um grupo ou uma pessoa) que prevaleça sobre os demais.

Nebulosa não designa, portanto, apenas um conjunto de organizações, associações e pessoas. A nebulosa, como veremos ao longo deste capítulo, é um método de organizar esse conjunto de forma que o termo comum do conjunto não se sobreponha às diferenças que o compõe, favorecendo uma atuação fluida, na qual militantes podem circular e, por meio dessa circulação, atuar politicamente. A história do movimento é um duplo procedimento de elaboração de contornos e definições do decrescimento, de um lado, e a manutenção da fluidez de seus limites, de outro. Veremos como o decrescimento foi um conceito que se constituiu a partir da sistematização e agrupamento de diversos questionamentos, ao passo que a própria constituição do conceito foi marcada pela recusa de uma univocidade de sentidos, como se a nebulosa fosse também um método de existência da mobilização.

Há que se levar em conta ainda que esse método é ao mesmo tempo o objetivo final da mobilização do decrescimento. Em outras palavras, a nebulosa não é só um método para garantir as diferenças que podem levar à transformação social, mas é o decrescimento na prática, ou a transformação ela mesma. Quando se milita em favor do decrescimento, é como se a forma de militância (que envolve as atividades individuais e as ações coletivas) fosse também uma realização no presente da sociedade que se defende para o futuro, na qual as relações (sociais e ecológicas, entre humanidade e meio ambiente que a cerca) são de extrema importância.

Nebulosa não é, portanto, apenas um vocabulário analítico, mobilizado neste trabalho para dar conta da multiplicidade de associações, coletivos, discursividades, conceitos, produções teóricas, protestos, ações de rua, revistas e jornais que, em uma medida ou outra identificam-se com a palavra decrescimento. Nebulosa é um conceito, um método de ação 
social, política e ecológica e uma forma de existência acionada pelos próprios defensores do decrescimento e o objetivo deste capítulo é explorar os rendimentos dessa noção e usá-la como guia para apreender uma mobilização social que soa como um caos à primeira vista de alguém que está de “fora”.

Por se configurar dessa maneira, a mobilização do decrescimento coloca em questão uma série de análises cujo arcabouço teórico-metodológico parece ser insuficiente para apreender um objeto tão fluido, cujos limites não existem (ou são dificilmente identificáveis) como um objetivo político. Na França, a literatura sobre mobilizações sociais vem se reformulando para tentar apreender as chamadas “novas formas”, mas é comum que haja uma fragmentação temática que, embora fiel aos pequenos coletivos, não consegue dar conta do modo como esses coletivos se articulam e a importância dessa articulação para a conformação de uma nova concepção de ação política. Paralelamente, as tentativas de apreender essa dimensão das mobilizações se restringem ao estudo da militância, como se o trânsito do indivíduo fosse o único modo de estabelecer relações. Como ficará evidente ao longo deste capítulo, a todo momento, tudo é como um nó de relações: os meios de comunicação, o consumo político e a militância são três entre as tantas outras possíveis maneiras de se estabelecer e dar corpo ao discurso das conexões.

Ao descrever aquilo que se entende por decrescimento, “alternativas locais” e “nebulosa”, este capítulo busca apreender os sentidos embutidos na reivindicação da novidade destes elementos, os quais se afirmam em contraposição à insuficiência de teorias e mobilizações sociais supostamente ultrapassadas. O que é que, desde os anos 1960 é rasurado do vocabulário do político, bem como de imagens de mundo formulados por setores que se dizem críticos de esquerda?

Antes de entrarmos no decrescimento propriamente dito, vale apontar em que contexto uma análise como esta se insere no Brasil. Aqui, a bibliografia mais comum sobre a relação entre política e meio ambiente é aquela que se debruça sobre os chamados conflitos ambientais (cf. LOPES, 2004), sobre as relações de força envolvidas em questões de desigualdade no acesso aos recursos territoriais e de desproporcionalidade dos riscos e das cargas de poluição industrial no Brasil. Poucos são os estudos voltados para mobilizações de classe média e parece haver um abismo entre os dois tipos de fenômeno social, tanto no 
campo da teoria ${ }^{38}$ quanto na realidade $\operatorname{concreta}^{39}$. Assim, embora não seja imediata a contribuição das análises de conflitos ambientais para a compreensão do movimento de decrescimento, os estudos brasileiros não devem ser desconsiderados de antemão, afinal podem iluminar a questão dos conflitos internos ou ligados ao decrescimento.

Há variações temáticas entre as abordagens dos conflitos ambientais. Algumas mostram o quanto as populações são afetadas; outras discutem mobilização social dos atingidos; outras ainda analisam e exploram os conflitos entre as partes envolvidas. Há também variações teóricas que mobilizam instrumentos analíticos distintos para dar conta dessas questões. Embora existam inúmeras que poderíamos levantar, fiquemos com aquelas que predominam atualmente e que são geralmente mencionadas por revisões bibliográficas (ALONSO, 2009; ALONSO; COSTA, 2002). Em primeiro lugar está a orientação habermasiana, cujo principal expoente é Eduardo Viola. Nesta linha, os movimentos ambientalistas brasileiro e global são pensados em termos de atores e setores ${ }^{40}$ - ou seja, a chamada tese da multissetorialização:

Todos os atores e processos (...) constituem o movimento ambientalista global, cujos valores e propostas vão se disseminando pelas estruturas governamentais, as organizações não governamentais, os grupos comunitários de base, a comunidade científica e o empresariado. O ambientalismo, surgido como um movimento reduzido de pessoas, grupos e associações preocupados com o meio ambiente, transforma-se num intenso movimento multissetorial.

VIOLA, 1996, p. 28

Tudo se passa como se houvesse um consenso ou um caminho inevitável para o consenso. Políticas de diversas ordens são implementadas, organismos internacionais são

38 É possível que os poucos estudos sobre mobilizações sociais desse tipo sejam decorrentes da proximidade (ou falta de estranhamento) entre pesquisadores e movimentos. Na cidade de São Paulo, por exemplo, os grupos de ciclo-ativistas, de defesa de animais, de ecologistas são povoados por estudantes e jovens pesquisadores universitários, de modo que esses movimentos são usualmente relacionados a posições políticas e não a temas de pesquisa, embora haja exceções.

39 No caso dos ciclo-ativistas paulistanos isso é bem evidente. Embora um "bicicletada" seja um evento sem identidade, não há uma grande diversidade de militantes. Também não há esforços para que as "bicicletadas" circulem por bairros periféricos da cidade, não são levantadas questões urbanísticas gerais e os cicloativistas são, em sua maioria, jovens brancos, de classe média e média alta que vivem no centro expandido da cidade.

40 São eles associações e grupos comunitários ambientalistas; agências estatais e de meio ambiente; organizações não governamentais cujos objetivos não são estritamente ambientalistas, mas incorporam a proteção ecológica como uma dimensão relevante de sua atuação; grupos científicos dedicados à problemática ambiental; certo setor do empresariado que orienta o processo produtivo por alguns critérios de sustentabilidade; políticos profissionais e partidos políticos; ambientalismo religioso; educação ambiental (jornalistas, educadores e artistas voltados para conscientização ambiental) (TAVOLARO, 2001). 
criados e a sociedade civil se organiza em associações de vários tipos, expressando uma comunhão entre as partes, em torno de uma preocupação comum: o meio ambiente. Assim, as negociações sobre o meio ambiente aparecem como um grande ganho para a sociedade, pois é através das questões ambientais que se produzem sociabilidade e integração entre grupos de interesses distintos e até mesmo opostos em outras esferas.

Há duas respostas à abordagem habermasiana dos conflitos socio-ambientais. Por um lado, as críticas ao modelo de desenvolvimento, progresso e crescimento no Brasil, que veem nos conflitos ambientais expressões de antigas contradições do capitalismo ou da sociedade industrial (cf. DUPAS, 2008; LOWY, 2005). É comum que encontremos, nessa linha, críticas a noções como "crescimento verde", "desenvolvimento sustentável" e greenwashing.

Por outro lado, há uma abordagem antropológica dos conflitos ambientais que considera o conflito como positivo, no sentido de produtor de relações e, portanto, fundamental para compreender os movimentos ambientais (cf. ZHOURI; LASCHEFSKI, 2010). Essa perspectiva compartilha algumas referências com pesquisas antropológicas sobre outros temas relacionados a conflitos, como a literatura sobre brigas de família que, embora não seja referência na área de conflitos ambientais, é interessante para pensar a nebulosa do decrescimento. Aqui o conflito não é nem uma perversão da sociedade, nem anterior a ela. “A sociedade não está para além ou aquém do conflito, mas o conflito é inerente ao campo social, um de seus elementos formadores essenciais” (MARQUES; COMEFORD; CHAVES, 2007, p. 34). Assim como a abordagem habermasiana, esses autores discutem a questão do conflito a partir da consideração de múltiplos atores e múltiplas vozes, mas a diferença é que aqui o conflito é como um instrumento metodológico que parte do princípio que a realidade social é múltipla ${ }^{41}$; já as teses da multissetorialização buscam (normativamente) o que unifica ou reconcilia as multiplicidades.

A literatura brasileira, portanto, pode não ser imediatamente relacionada com a mobilização do decrescimento mas aponta para uma questão que parece central para compreender o decrescimento, que é a questão do conflito. Se no Brasil os conflitos ambientais estão relacionados a desigualdades sociais, na França a questão ambiental vem, desde os anos 1960 sendo colocada como um problema que ultrapassa esses problemas, como

41 "O conflito é uma categoria analítica que visa recobrir, sem pretensão de substituir, o campo semântico de categorias nativas e, portanto, apresenta-se simultaneamente como instrumento heurístico e como conceito com estatuto próprio” (MARQUES; COMEFORD; CHAVES, 2007, p. 30). 
foi discutido no capítulo precedente. Tanto o tema quanto as análises são como que espectros apagados pela mobilização do decrescimento, como ficará mais claro ao longo do capítulo. Esse apagamento é efeito de uma forma de mobilização na qual os conflitos são positivados e não tratados como algo destrutivo; o conflito entre as diferenças deve ser inerente ao campo do decrescimento para que a mobilização não se converta em um movimento exclusivo, hierarquizado e unívoco.

\section{1. História(s)}

\section{1. 1. Nasce o decrescimento como conceito}

Existe algum sentido mínimo compartilhado que faz com que a palavra “decrescimento” faça parte de um vocabulário específico, mas há, paralelamente, uma recusa de fazer com que a inteligibilidade do termo seja efeito de sua univocidade. Reconstituir a "história” do decrescimento é uma maneira de (tentar) apreender e entender esse duplo movimento. De acordo com um antropólogo engajado no movimento há cerca de dez anos ${ }^{42}$, o decrescimento se constituiu em um terreno fértil. Segundo ele, nos anos 1990 houve uma nova ascensão de movimentos sociais, embora em menor escala do que a ocorrida em 1968. Em 1995, na França, houve uma grande mobilização contra o plano de reforma da aposentadoria e da seguridade social, quando até mesmo intelectuais de grande notoriedade se posicionaram. No fim da década, surgiram ainda os movimentos anti-globalização, em profundo diálogo com a repercussão do movimento zapatista na Europa e os questionamentos ao neoliberalismo circulavam com força em jornais como no Le Monde Diplomatique.

Em meio à retomada de mobilizações, ocorreu a II Conferência das Nações Unidas sobre Meio Ambiente e Desenvolvimento Humano, em 1992 no Rio de Janeiro, levando de volta a questão ambiental para o debate político. Os anos 2000 conheceram uma crescente mobilização relativa à ecologia e estava em curso uma articulação inédita entre críticas ao neoliberalismo e questionamentos político-ecológicos - José Bové, por exemplo, é um personagem emblemático que se tornou referência para essa articulação, ao fazer um desmanche de um Mc Donald's em agosto de 1999.

$\mathrm{Na}$ opinião do mesmo militante, o decrescimento foi crucial para estabelecer

42 Um de meus interlocutores no campo, em Lyon. 
definitivamente (ou estabilizar) a problematização do progresso e do crescimento econômico em função de questões ecológicas, ou vice-versa, na esfera pública. Em 2002, foi realizado um colóquio chamado Refaire le monde, défaire le developpement em Paris sob organização do grupo La ligne d'horizon, uma micro-associação fundada em 1988, juntamente com o Le Monde Diplomatique e com o projeto MOST da Unesco. Algumas correntes do decrescimento hoje identificam nesse colóquio a origem do decrescimento na França. Há relatos de que o tema da crítica do crescimento foi central no evento e, nas atas da conferência publicadas em 2005, o parecer da própria organização sobre as repercussões do evento é o seguinte: "Parece que as ideias ditas de pós-desenvolvimento e decrescimento conheceram, ao menos na França, uma difusão sem precedentes".

Na conferência, um tom de novidade que pairava no ar. Depositava-se ali uma grande esperança. Desde a abertura do evento, falou-se muito sobre a importância dos movimentos anti-globalização. Alain Gresh (2002), jornalista do Le Monde Diplomatique, disse que os movimentos anti-globalização foram de extrema importância pelo fato de terem aberto a possibilidade de fazer críticas a coisas que antes eram tomadas como solução, como o desenvolvimento, o neoliberalismo e ao progresso. Ao mesmo tempo, aos olhos do jornalista a Conferência parecia dar um passo adiante na medida em que oferecia soluções aos problemas que os movimentos levantaram. Era como se o evento reiterasse as críticas do movimento anti-globalização, somando a elas o desejo de refazer o mundo. Mas Gresh não era o único a expressar o desejo de construir alternativas: "Amigos, a boa notícia é que, enquanto algumas pessoas são induzidas a destruir o mundo, outras pessoas estão comprometidas a refazê-lo, e fazer dele um lugar em que valha a pena viver. E essa conferência é um exemplo [disso]", disse Rajagopal (2002), militante indiano convidado para fazer uma apresentação oral. Em suma, o que se colocava ali era a oposição entre “criticar” e negar o mundo existente e “propor” novas maneiras de experimentar as relações sociais fora do registro que se critica.

O sentimento de esperança que se expressava naquele momento era acompanhado por menções não só aos movimentos anti-globalização, mas também ao Fórum Social Mundial (FSM) de Porto Alegre. O Colóquio era visto como uma possibilidade totalmente inovadora porque estava comprometido não só com desfazer o desenvolvimento, mas, sobretudo com a possibilidade de refazer o mundo. As referências ao FSM não eram aleatórias, já que a proposta de dar um passo além das críticas ao neoliberalismo e construir alternativas tinha 
sido a tônica da formulação e realização do primeiro Fórum Social Mundial, em 2001.

É como se diante da nova forma de fazer política que o FSM trazia consigo, tomar posição seria pouco. As exuberantes poéticas da oposição a Davos são regularmente compensadas pela defesa enfática de que se tratava definitivamente de mais do que uma mera imagem especular do Fórum Econômico. Nas análises e balanços, o Fórum de Porto Alegre, é celebrado como um passo além e positivo com relação às grandes manifestações de rua que marcaram o momento político do final da década de 1990 e os primeiros anos do século XXI .

(DI GIOVANNI, 2011, p. 14)

A “novidade” do Colóquio de 2002 não era decorrente do ineditismo - embora seja o que apareça em algumas falas. O sucesso do evento não é produto de sua exclusividade, mas de fazer ressoar questões sobre fazer política e promover mudanças sociais significativas que circulavam pelo mundo. Mas por que razões, então, apenas o Colóquio seria apontado como fundador do decrescimento? Por que não o FSM ou mesmo as manifestações de Seattle? Embora o colóquio não tenha tido a repercussão de um evento o Fórum Social Mundial, estavam presentes cerca de 700 participantes e hoje é uma referência amplamente conhecida entre militantes do decrescimento. O que era relativamente exclusivo ao Colóquio não era a sua proposta de "refazer o mundo", mas de refazê-lo sem ter que passar pela noção de desenvolvimento - era como um ponto de conexão entre críticas já em curso (cujos precursores eram Ivan Illich, Bernard Charbonneau, André Gorz, Jacques Ellul, Cornelius Castoriadis, entre outros) e a ação concreta.

Latouche (2002), que logo se tornou uma sumidade nos meios intelectuais do decrescimento, estava bastante engajado, no Colóquio, em defender que o desenvolvimento não seria, em hipótese alguma, uma solução para os problemas postos pelo neoliberalismo e pela globalização. Muitas outras falas consistiram em expor dados para defender o argumento de que o desenvolvimento não trouxera melhorias de fato para as pessoas e para o meio ambiente. Algumas pessoas (inclusive do público ouvinte) abordaram o problema da falsa face promissora do desenvolvimento e alguns usaram o termo ideologia para explicar que a economia, o progresso, o desenvolvimento e o crescimento econômico são tão fundamentais como categorias que ninguém consegue conceber outro mundo sem elas - muito menos nos países em desenvolvimento (cf. TRAORÉ, 2002). Por essa razão, Latouche defendeu que a solução seria a "descolonização do imaginário" e o decrescimento, e não uma transformação 
ou melhoria do desenvolvimento (daí as duras críticas ao desenvolvimento sustentável, social, alternativo, social, humano, local, etc ${ }^{43}$ ).

A associação La Ligne d'Horizon, organizadora do colóquio, é um grupo de estudos dedicado ao tema do pós-desenvolvimento, inspirado na produção de François Partant, crítico feroz dos modelos de desenvolvimento implementados nos países do então chamado Terceiro Mundo. Em 1988, um ano após sua morte, foi criada a associação, cujo nome vem de um livro póstumo no qual critica o desenvolvimento francês e europeu nos Trinta Gloriosos (período compreendido entre 1945 e 1975). À luz das reflexões sobre o desenvolvimento, a presença numerosa de personalidades indianas no evento era uma forma de dizer que o que se discutia ali eram problemas de ordem global - ou seja, a crítica ao desenvolvimento não era algo exclusivo a países desenvolvidos, cabendo também a países com grande desigualdade social como a Índia pensar nessas questões.

Nesse mesmo ano, o ex-publicitário Vincent Cheynet, um dos fundadores da associação Casseurs de Pub em 19994, trabalhava na revista Silence (ambas em Lyon) como voluntário encarregado da editoração. Essa revista nasceu em 1982, momento em que a ecologia estava em baixa, como constatam tanto militantes quanto historiadores. O expublicitário foi responsável pela organização de dois dossiês sobre o tema decrescimento ${ }^{45}$, com textos de Serge Latouche, François Schneider, Pierre Rhabi, Bruno Clementin e do próprio Cheynet ${ }^{46}$ escreveram artigos apresentando o tema para um público mais amplo e no ano seguinte publicou um livro com artigos que haviam saído na revista (BERNARD; CHEYNET; CLÉMENTIN, 2003). Ainda em 2002, o jornalista Hervé Kempf escreveu um artigo para o jornal Le Monde divulgando o número 280 da Silence, "uma revista povoada de ecologistas irredutíveis [que] ainda resiste ao pensamento monolítico” (KEMPF, 2002).

43 Houve um ateliê exclusivamente dedicado a esse tema durante o evento ("Atelier 1: Les habits neufs du développement”, 2002).

44 Casseurs de Pub, em português "quebradores de publicidade", é uma associação direcionada para a crítica da publicidade e desde sua fundação, promove campanhas contra o consumo, contra a televisão e contra Fórmula 1. Sua história é desconhecida por grande parte dos militantes envolvidos com alguma mobilização anti-publicidade hoje e aparentemente o grupo se reduz atualmente a seus fundadores e o jornal La Décroissance tornou-se seu carro chefe.

45 Número 280 de fevereiro de 2002 e 281, de março do mesmo ano.

46 Quase não havia mulheres entre os especialistas no assunto, embora hoje seja comum a incorporação do feminismo como pauta do decrescimento. No site do Parti Pour la Décroissance, no setor das eleições legislativas de 2012, está escrito: “O programa dos objecteurs de croissance, apoiado por Paul Ariès, é radicalmente anti-capitalista, anti-produtivista, ecologista, feminista e internacionalista" ("DécroissanceElections”, [S.d.]). 
Alguns militantes que se recordam desse momento acreditam que o artigo de Kempf foi fundamental para apresentar o decrescimento para fora dos círculos militantes.

Em 2003, Cheynet organizou o colóquio sobre decrescimento em Lyon, no prédio da prefeitura da cidade. Em uma entrevista, Jacques Grinevald elegeu esse evento como marco fundador do decrescimento:

Em primeiro lugar, o decrescimento ainda é um movimento social de uma pequena minoria. Não devemos exagerar sua importância. Ele começou a ter mais visibilidade há apenas dois anos [2003] em Lyon, na França, depois de várias tentativas de pequenas associações de organizar um colóquio sobre o decrescimento. Essas associações eram as revistas "Silence", uma publicação ecologista, pacifista e ligada às comunidades alternativas; a "L'Ecologiste", que apesar de recente é uma versão francesa de uma revista ativa há trinta anos na Inglaterra e um grupo francês extremamente ativo e criativo chamado "Casseurs de Pub" (Destruidores de Propaganda).

O colóquio de Lyon aconteceu num salão muito bonito, na prefeitura da cidade. O local era um pouco paradoxal. Lembro-me que a primeira coisa que a assembleia fez foi pedir que as centenas de lâmpadas acesas fossem desligadas. Afinal, o sol que atravessava as janelas estava a pino. Esse foi nosso primeiro gesto de decrescimento.

(GRINEVALD, 2005)

Segundo um dos presentes no evento, foi aí que o decrescimento surgiu como movimento que congregava pessoas já engajadas em alguma medida: "Fundado em 2003 em Lyon, na França, o 'decrescimento' é um movimento que tem acolhido adeptos nos grupos de altermundialistas, sobretudos ecologistas e decepcionados com a esquerda" (THOELE, 2005). A “alternativa” àquilo que se oferecia naquele momento como crítica social e como esquerda era uma sistematização das críticas ao crescimento, ao desenvolvimento e à sociedade de consumo feitas por pessoas distintas e em contextos relativamente diversos, que já estiveram de alguma forma presentes ou representadas no colóquio de 2002, mas agora explicitamente sob a rubrica do decrescimento. A sensação dos participantes foi a de encontrar um espaço legítimo para as críticas que faziam, como se o termo decrescimento tivesse aberto um espaço no mundo para uma série de discursividades dispersas e desencontradas. Serge Latouche faz um parecer muito semelhante sobre o Colóquio de 2002: “diante do triunfo do ultraliberalismo e da proclamação arrogante do TINA ("there is no alternative”) de Margaret Thatcher, o pequeno grupo anti-desenvolvimentista do qual eu fazia parte não podia mais se contentar com uma crítica teórica quase confidencial” (DUVERGER, 2011, p. 9). E, como 
relata Alain Gras: “eu era anti-progressita, mas agora sou de maneira legítima. Hoje é legítimo ser anti-progressista”.

Em março de 2004, o ex-publicitário lançou o jornal bimestral La Décroissance e se desligou da revista Silence. Segundo o relato de muitos militantes, quando sua própria publicação começou a circular, seu caráter era inovador, trazia a público novas e interessantes críticas. Repleto de ilustrações bastante ácidas, o jornal até hoje é menos um veículo informativo do que formativo: não há muitas notícias, divulgação de eventos ou outras atualidades, mas há muitos textos longos dedicados a expor temas como energia e petróleo e consumo. Essa teria sido a primeira publicação a definir-se pelo decrescimento e hoje algumas pessoas encaram o jornal como uma tentativa de monopolizar o movimento - embora Cheynet alegue o oposto ${ }^{47}$. Segundo análises da história do movimento, a publicação foi responsável por lançar o conceito de decrescimento no espaço público (FLIPO, 2007) e teria transformado uma palavra de circulação marginal em slogan (HENST, 2007).

Quando decrescimento já era um termo que encontrava eco em várias cidades da França, Cheynet organizou em 2005 a Marche pour la Décroissance (marcha pelo decrescimento), como um evento na campanha do Casseurs de Pub contra a Fórmula 1. desta vez, o protagonista principal foi François Schneider, que partiu da pequena cidade Luc-enDiois em julho de 2004, acompanhado apenas de uma mula chamada Jujube, para chegar a Lyon $^{48}$, de onde sairia a marcha. Até lá, Schneider foi como um "mascate" do decrescimento, nas palavras de militantes e do próprio jornal La Décroissance: parava em pequenas cidades para difundir o decrescimento, organizava debates, pequenas conferências e conversava com as pessoas que encontrava no caminho.

Em junho chegou a Lyon, de onde saiu a marcha até a cidade de Magny-Cours, sede do Grande Prêmio da França de Fórmula 1. O trecho foi percorrido ao longo de um mês, com um número variável de pessoas em cada parte do trajeto ${ }^{49}$. Na época, foram publicados diversos relatos que enfatizavam o caráter “concreto” do decrescimento (por oposição ao decrescimento como conceitos e reflexões teóricas), que consistia em

Simplicidade, frugalidade, solidariedade; marcha, descanso, música, canto,

47 Comunicação pessoal.

48 Luc-en-Diois fica cerca de 200 quilômetros ao sul de Lyon.

49 Há quem diga que cerca de 2.000 pessoas participaram da marcha ("Historique du mot”, 2006), enquanto outros falam em 500 participantes (BAYON; FLIPO; SCHNEIDER, 2010). Outras marchas aconteceram no mesmo período, indicando um florescimento rápido do decrescimento no país. 
alimentação saudável e natural (ervas e plantas colhidas ao longo do caminho, produção local orgânica, etc), ateliês-debates sobre temas diversos (software livre, mídias alternativas, agricultura biodinâmica, política, técnicas de relaxamento, etc). Tempo para viver, para (re)encontrar uma felicidade simples, para contemplar, para (re)encontrar, construir e e renovar relações... Um funcionamento de auto-gestão democrática; cada dia uma ou mais associações com regras simples [se formavam], onde eram tomadas decisões coletivas. Uma autonomia individual, solidariedade simples e compreensão...

HUGUES, 2005

No final, chegaram cerca de 500 pessoas em Magny-Cours, entre elas personalidades como José Bové. Durante a marcha propriamente dita, a organização promoveu debates, discussões, conferências, festas e noites musicais e sugeria locais para hospedagem, como fazendas, campings e estádios municipais. O objetivo era envolver grupos locais (associações e coletivos organizados com atuação nas pequenas cidades), como se a marcha fosse antes uma forma de colocar em contato grupos e pessoas já envolvidas e/ou engajadas de alguma forma com questões que parecessem afinadas com a proposta dos organizadores do evento, do que propriamente divulgar o decrescimento pelo país.

Aqui já estava presente certa constituição do decrescimento como nebulosa, sem centralização ou hierarquia. As fotografias mais comuns são imagens dos círculos feitos por todos os participantes, sobretudo nas reuniões dos acampamentos para encaminhar propostas e resolver problemas de forma "auto-gerida”. Ao mesmo tempo, isso não excluía os conflitos: há alguns relatos de participantes da marcha de que naquele momento já havia tensões entre Cheynet e outras pessoas, como se diferentes concepções de decrescimento entrassem em choque. Bastaria criticar o crescimento ou seria preciso colocá-lo em prática? E o que seria colocar o decrescimento em prática? Como conjugar as duas coisas? Essas e outras questões expressavam as divergências que muitas vezes assumem um tom pessoal ${ }^{50}$, mas que também envolvem disputas pelo próprio termo decrescimento. Do lado da crítica, há quem defenda como alvo o capitalismo; outros combatem a sociedade do consumo; e outros ainda, o crescimento econômico em geral, independente de ser uma sociedade capitalista ou socialista

50 Vincent Cheynet está envolvido em diversas querelas com outros militantes do decrescimento, mas as tensões são relativamente veladas. Algumas vezes, os conflitos assumem tons pessoais, sob forma de acusações morais envolvendo Cheynet e seus colegas. Ao mesmo tempo, tais acusações se misturam com conflitos acerca dos sentidos da militância e da possibilidade de conciliação entre teoria e prática. Por essa razão, foi possível preservar as pessoas envolvidas nos desentendimentos, acentuando apenas o aspecto "político" dos conflitos. 
Vincent Cheynet e seu jornal La Décroissance assumiram uma força relativa no interior dessas divergências, afinal o primeiro foi um dos responsáveis reconhecidos por apresentar o decrescimento como sistematizador de uma série de críticas sociais. Mas ao mesmo tempo, tornou-se um alvo cada vez mais evidente, sob o argumento de que era pouco propositivo e não conjugava com a crítica a elaboração de propostas alternativas à sociedade de crescimento. Mesmo personalidades próximas a Cheynet começaram a dirigir-se ao jornal com ressalvas e hoje muitos militantes que conhecem as pessoas envolvidas diretamente com o periódico dizem que a equipe da redação está relativamente isolada no cenário do decrescimento.

Em 2006, foi lançada a revista Entropia, com a proposta de estabelecer os fundamentos teóricos do decrescimento. Diante da multiplicação de publicações e formas diversas de divulgação do decrescimento, a revista propunha ser um espaço de reflexão exclusivamente sobre o decrescimento, já que as demais publicações, como a Silence, a Ecorev', a L'Écologiste apenas lançariam questionamentos, sem aprofundá-los. Mas não era apenas diante dessas publicações que Entropia se colocava. O sucesso do jornal La Décroissance era outra motivação da criação de uma revista de “reflexões sérias”: debates aprofundados e mais intelectualizados, sem ironias e piadas polêmicas ${ }^{51}$.

Ao mesmo tempo, o comitê que elaborou a revista não tinha o objetivo de se contrapor ao jornal ou às demais publicações, porém de “complementá-las” (cf. HENST, 2007), no sentido de oferecer outra démarche do decrescimento e atingir certo público intelectual, nem sempre alvo dos outros meios de comunicação. Uma abordagem como essa implica em uma certa concepção de decrescimento, a qual envolve questões filosóficas, antropológicas e éticas, não bastando fazer críticas simplificadas e imediatas, nem bastando adotar estilos de vida supostamente libertários sem que se reflita sobre a natureza das relações sociais, culturais, morais, políticas e econômicas.

Foi partilhando o essencial dessas interrogações maiores que um pequeno grupo de pesquisadores, universitários ou não, decidiu propor uma revista de estudos teóricos e políticos sobre o decrescimento: Entropia. [...] Entropia se inscreve na longa tradição de revistas de ideias e engajamento, lugar de expressão privilegiada para um pensamento coletivo nascente e que se constrói ao longo do tempo. Um pensamento sobre a crista das interrogações fundamentais de nossa época; pela ampliação da tomada de consciência de

51 Latouche (2007) relata que alguns artigos mais profundos foram recusados pelo jornal porque eram muito longos, muito “intelectualóides”, etc. 
uma situação sem precedente da condição humana; para o enriquecimento do imaginário teórico, poético e político do pós-desenvolvimento.

BESSON-GIRARD; LATOUCHE, 2006.

Cada número da revista apresenta um tema específico e é comum encontrar os mesmos autores escrevendo sobre questões diversas. Há também pessoas que são convidadas pelo corpo editorial a escrever um artigo, como no caso de um número previso para 2013 sobre decrescimento e feminismo, no qual contribuiriam apenas mulheres que o corpo editorial julgasse interessantes. Parece haver, dessa maneira, um esforço na consolidação de uma linha específica de ideias e reflexões sobre o decrescimento.

Paralelamente, há uma preocupação em dizer a diversidade é bem vinda: o "recorte temático é um convite ao confronto de diferentes pontos de vista sobre um tema particular. Há um verdadeiro ensejo de construção de um projeto político por meio do convite de intelectuais para debaterem sobre um tema relativamente preciso” (HENST, 2007). Segundo BessonGirard, diretor da publicação, a revista é aberta ao envio de artigos mas no site não há informações e há uma parte dedicada aos autores, e ao todo, são 19 pessoas que publicaram nos 12 números.

Considerando-se que um dos pontos que gera tensões no decrescimento é a relação entre teorização e prática, a revista assume um ponto de vista a esse respeito que a diferencia das demais. Entropia, ao se propor teórica, vê na reflexão sobre o mundo seu posicionamento político porque a teoria teria o papel de iluminar o processo de transformação social. Nesse sentido, o decrescimento é inevitável por causa dos rumos que o planeta tomou, então é preciso que se teorize sobre qual o tipo de decrescimento que queremos (cf. HENST, 2007). Já o jornal La Décroissance, menos teórico, apresenta um projeto de decrescimento eminentemente crítico: nomeia seus inimigos e está engajado em apontar contradições no sistema de crescimento.

Os temas trazidos pelas duas publicações também traduziam suas diferenças em outros termos, em uma variação da oposição entre teoria e prática: a revista mais abstrata tratava de temas como ética, política, técnica e utopia enquanto os primeiros números do jornal $L a$ Décroissance, entre 2004 e 2005, abordavam basicamente três temas: apresentar e justificar a crítica ao crescimento econômico; a crítica ao consumismo como fonte de transformação social (se nossa sociedade é baseada no consumo, temos que acabar com ele para transformar 
os fundamentos do crescimento); e o problema do pico do petróleo (as pesquisas revelavam o fim próximo das reservas de petróleo, o que culminaria em uma crise sem precedentes, a não ser que tomássemos a decisão de não mais usar o petróleo). Cada uma das publicações construiu sua versão do decrescimento articulando de modo particular a relação entre teoria, reflexões e transformação social.

Em 2007, franceses adeptos do decrescimento ligados à academia, dentre eles François Schneider, criaram o grupo internacional Research and Degrowth (R\&D), "uma associação de pesquisadores que visa desenvolver um conjunto de conhecimentos de forma pluridisciplinar, tanto teórica quanto prática, com vistas a favorecer as perspectivas de pousar delicadamente sobre o decrescimento igualitário, global, sustentável, físico e econômico das atividades humanas” (MYLONDO, 2009 - grifo meu). O R\&D, com o apoio de outras associações ligadas à economia ecológica, organizou em Paris, em 2008, a Primeira Conferência Internacional de Decrescimento Econômico pela Sustentabilidade Ecológica e Igualdade Social ("First International Conference on Economic De-Growth for Ecological Sustainability and Social Equity”, 2008) e a Segunda Conferência Internacional em Barcelona, no ano de 2010.

Na conferência de 2010, os organizadores tinham a intenção de "seguir um novo formato”, que incluísse tanto palestras e mesas redondas com renomados especialistas em decrescimento, mas, que desse espaço também (e sobretudo) a apresentação de pôsteres e grupos de trabalho participativos (ICTA; RESEARCH \& DEGROWTH; UNIVERSIDAD AUTONOMA DE BARCELONA, 2009). Os diversos textos que circularam na internet divulgando o evento enfatizavam o caráter participativo que possibilitaria a criação e definição de uma agenda de pesquisa e uma agenda política sobre o decrescimento.

O evento de Barcelona é uma continuação da bem sucedida conferência sobre decrescimento que ocorreu em Paris em 2008 [...]. Busca-se agora articular cientistas e organizações da sociedade civil para pensar propostas políticas e prioridades de pesquisa. O evento contará com palestras de importantes nomes ligados ao decrescimento, mas seu principal componente serão os grupos de trabalho que discutirão e desenvolverão propostas concretas, as quais serão reportadas para a assembleia geral. Apresentações de trabalhos científicos de assuntos diversos serão realizadas em forma de poster.

A contribuição dos grupos da sociedade civil é crucial para as discussões, criação e desenvolvimento de propostas políticas. Em contrapartida, acreditamos que as relações estabelecidas e as ideias criadas no evento 
podem ser fundamentais para campanhas, trabalhos e atividades promovidas pelas associações e entidades.

SEKULOVA; RIJNHOUT, 2009 - grifo meu

O formato, especialmente dos grupos de trabalho ${ }^{52}$, correspondia à tentativa de lidar com os “aspectos práticos” do decrescimento (SCHNEIDER, 2010). Os grupos de trabalho eram definidos de acordo com elementos “concretos”, como trabalho, dinheiro e moeda, consumo de água, educação, novas tecnologias, comércio, estratégias políticas e economia. No grupo de trabalho Moratoria on new infrastructures foram debatidas as possibilidades da construção de novas infraestruturas, com base em textos pré-estabelecidos ${ }^{53}$ e em informações e experiências trazidas por associações e especialistas no assunto. Durante o debate, algumas pessoas opuseram-se veementemente à implantação de novas linhas de trem por conta dos danos ambientais provocados. Mas sem trens, como seriam feitos os deslocamentos?, perguntavam outras pessoas. Melhor então seria suprimir estradas, quebrar o asfalto e usar o entulho para fazer móveis. Falou-se muito também sobre o impedimento de novos aeroportos e restrição de funcionamento aos existentes, por conta das altas taxas de poluentes emitidos por vôo. Ao fim da discussão, foram elencadas as principais propostas que, em seguida, foram apresentadas para os demais participantes da conferência durante uma confraternização. No pátio central da Universidade de Barcelona foram pendurados cartazes com as propostas de todos os GTs do dia, enquanto os participantes, exaustos de um longo dia de trabalho e muita discussão, bebiam vinho de forma “decrescente”, em porróns ${ }^{54}$.

A perspectiva de construir uma agenda política e uma agenda teórica não era sinônimo de criar uma coerência entre as centenas de pessoas do mundo todo que estavam presentes, mas sim, de evidenciar as múltiplas dimensões dos problemas e das soluções. O decrescimento deveria ser uma transformação e não uma transição; para tanto, a organização do evento orientara as atividades de forma a criar possíveis cooperações (cf. SCHNEIDER, 2010).

52 As seções de posteres e apresentações orais - mais próximas do formato comum de eventos acadêmicos ocorreram pela manhã, com cerca de duas horas de duração cada, enquanto as seções de grupos de trabalho chegaram a durar quatro horas.

53 Todos os GTs contavam com alguns textos de base, produzidos por autores diferentes, mas que tinham alguma relação, mesmo que indireta, com os organizadores do evento. Esses textos foram encaminhados para os participantes que, no ato da inscrição, haviam indicado os grupos de sua preferência.

54 Jarros de vidro da região da Catalunha. 
Todos esses acontecimentos são bastante conhecidos entre diversos circuitos militantes. Embora não sejam os únicos, são considerados os responsáveis por criar e consolidar o decrescimento como um conceito na França e expandi-lo para diversos horizontes (DUVERGER, 2011). As associações e coletivos que hoje se consideram decrescentes de alguma forma poderiam ter suas histórias traçadas por outras vias, pois muitas vezes elas já existiam ou emergiram temporalmente em paralelo aos eventos já narrados, sem, no entanto, associarem-se imediatamente a eles. Os dois colóquios, de 2002 e 2003, assim como a criação do jornal La Décroissance em 2004 e a revista Entropia em 2006 consolidaram proposições que relacionavam meio ambiente e política acerca dos limites ecológicos e sociais para o crescimento econômico. Antes desse período, essa palavra não fazia sentido como nome de qualquer mobilização político-ecológica, ao contrário do que verificamos hoje na França ${ }^{55}$, e somente com a sistematização conceitual dessas questões pelas revistas, pelos colóquios e pelos jornais é que as "práticas” de decrescimento puderam se identificar entre si sob a rubrica de uma mobilização político-ecológica.

Ao mesmo tempo, os enunciados, as práticas, os coletivos, as associações e mesmo as pessoas compreendidas pela palavra decrescimento não se limitam a ela. A revista Silence, por exemplo, foi a primeira publicação a fazer circular um dossiê sobre o decrescimento e ainda hoje é associada ao decrescimento, mas publica uma série de artigos sobre outros temas e é lida por pessoas que não necessariamente se definem como adeptas do decrescimento.

A linha aparentemente coerente que segue o nascimento do conceito de decrescimento é logo contrabalançada pela recusa de unificá-lo. Se considerarmos as formas de um colóquio ou de uma revista de artigos como a Entropia, perceberemos que o que está em jogo não é a delimitação de um conjunto exclusivo de ideias e propostas de decrescimento. O debate, que é característico desse tipo de organização (um colóquio ou uma revista acadêmica), jamais foi colocado como um instrumento para se chegar ao decrescimento. É como se o debate fosse tão ou mais importante do que as conclusões que dele deveriam se originar. Embora possamos identificar tendências, sobrepõe-se a forma nebulosa que não permite a monopolização do decrescimento por nenhuma delas.

Além disso, a própria noção de decrescimento se constituiu costurando uma série de elementos já existentes, dando novos rumos a eles. Os intelectuais dos colóquios, por 55 Cf. nota 1. 
exemplo, eram engajados com outras questões antes dos eventos e o decrescimento se mostrou uma oportunidade de colocá-los em relação. Outro exemplo é o estabelecimento de vínculos entre decrescimento e crítica da publicidade, questão cara a Vincent Cheynet, sendo que o jornal La Décroissance foi lançado e ainda hoje está submetido à associação antipublicidade Casseurs de Pub.

\section{1. 2. Etiquetando e costurando o decrescimento: nebulosa como método}

A revista Silence é considerada atualmente um marco central na história do decrescimento por ter publicado os artigos já mencionados, mas seu reconhecimento na nebulosa não se deve somente a esse fator. Quando saíram os números em 2002, Silence já tinha 20 anos de existência e era uma publicação conhecida nos circuitos de militantes da ecologia política, que divulgava iniciativas locais - produção de alimentos orgânicos em determinada região da França, por exemplo - e reflexões que articulavam meio ambiente, política, economia e sociedade. Ao se dedicar às "alternativas” (nome dado às iniciativas locais consideradas alternativas ao modo de funcionamento, produção e consumo vigente), a revista tomava a multiplicidade de coletivos e de perspectivas como meio de colocar em prática uma outra sociedade (que, por sua vez, seria povoada por esses coletivos múltiplos). A palavra decrescimento passou a ser uma das palavras que nomeava os mapeamentos de alternativas que a revista costumava fabricar.

O site da revista disponibiliza um índice de cada ano para consulta, no qual todos os artigos são classificados e identificados em categorias. A palavra “decrescimento” entrou para o índice em 2003 como uma subcategoria de "Política”. Os artigos classificados nessa rubrica eram aqueles que apresentavam reflexões sobre decrescimento e democracia ou sobre os problemas da modernidade. Em 2004, pela primeira vez, a palavra “decrescimento” apareceu para classificar uma “alternativa local”, como se no interior da própria revista o decrescimento consistisse tanto em discussões mais abstratas como em práticas concretas.

Ao tratar o decrescimento dessas duas maneiras, a revista seria como que um “intermediário" na construção do decrescimento como nebulosa: por um lado, ela etiqueta iniciativas existentes como decrescentes, por outro, o próprio ato de classificar as alternativas é uma proposta de abrir possibilidades para que o decrescimento se expanda pela França, sobre formas diversas. 
Seja pela história do decrescimento, seja pela revista Silence, pode-se ver que o modo pelo qual o decrescimento se constrói como um conceito é também responsável por transformá-lo em uma nebulosa difusa de iniciativas, pessoas, ideias, etc. Como se a criação do decrescimento fosse ao mesmo tempo uma sistematização de ideias-chave, de questões centrais ou de definições gerais e uma explosão em pequenos grupos locais (as alternativas da revista Silence) ou em pontos de vista (que se enfrentam em revistas e em colóquios).

A ambiguidade entre criar um decrescimento que seja ao mesmo tempo um conjunto mais ou menos sistematizado de questões e também uma nebulosa é a questão da nova geração do Parti Pour la Décroissance. Em 2006, Vincent Cheynet, Bruno Clementin e Yves Scaviner criaram o Parti Pour La Décroissance (PPLD). Vincent Cheynet se candidatou às eleições municipais de 2007 e conseguiu 1\% dos votos. Apesar de pouco expressivos, os votos apontam algo interessante, disse o editor chefe do jornal ${ }^{56}$ : na região de Rhône-Alpes há um número relativamente grande de pessoas pensando em decrescimento. Mas no mesmo ano o PPLD se enfraqueceu e o jornal desligou-se do partido.

Em 2008, o PPLD foi relançado por "novos(as) e jovens militantes", como Rémy Cardinale, Vincent Liegey, Christophe Ondet, Stéphane Madelaine, Affifia Kadri, Christophe Degennes e Olivier Bouly (cf. PARTI POUR LA DÉCROISSANCE, 2012a), que pretendiam renovar o partido. A moção escrita pelo grupo em 2008 tentava justificar a articulação entre decrescimento e eleições, tema tão controverso entre militantes pois muitos vêem a via partidária como contraditória com a proposta de criar formas de vida alternativas e autogeridas. Para explicar a retomada do partido, essa moção afirmava que “a soma de comportamentos individuais ecologicamente responsáveis” não seria suficiente para fazer a sociedade sair do impasse no qual se encontra; é por isso que o decrescimento deveria se impor na cena política, no sentido nobre da palavra (viver na cidade). Através desse engajamento, o Decrescimento permitiria aos cidadãos se reapropriarem da democracia (PARTI POUR LA DÉCROISSANCE, 2009, p. 1). Mas estar presente nas eleições também não era suficiente e por isso o novo grupo decidiu desenvolver alguns meios de comunicação (como um site e informativos) e se comprometeu a colocar em prática uma rede de grupos locais. O partido ainda estaria aberto a incorporar experiências alternativas relacionadas a políticas sociais e meio ambiente para inserir o projeto de decrescimento em uma perspectiva

56 Entrevista Vincent Cheynet, 2010. 
global. O decrescimento era visto como um questionamento do crescimento econômico e o partido seria a forma de encontrar respostas para os problemas ecológicos e sociais.

O decrescimento reorganizou em certa medida o campo das mobilizações sociais ligadas às questões ambientais na França. Atribuiu novos sentidos às “alternativas” existentes (como fez a Silence), mas também ofereceu um vocabulário para movimentos emergentes que, por sua vez, não eram necessariamente um movimento social no formato tradicional, como o PPLD, como explica Emilie Henst.

Essa mobilização [mouvance], que apareceu há alguns anos, reagrupa diferentes correntes, principalmente críticas a respeito da sociedade do consumo e da perversidade das influências exercidas pela publicidade, como a associação Casseurs de Pub, pessoas críticas ao desenvolvimento como Serge Latouche, e ecologistas.

A mobilização de decrescimento concorda com a ideia de reagrupar os "objetores de crescimento" mas o projeto de decrescimento não clama por um consenso. O termo e o projeto nele subentendido não são definidos unanimemente. Existem divergências no seio da mobilização. A mobilização, pouco estruturada, pode se confundir com a militância subversiva que não tem um projeto e um conteúdo por trás.

HENST, 2007.

O PPLD é interessante para compreender essa ambiguidade porque, embora seja um partido e precisar de um programa, recusa-se a tomar o decrescimento como um programa fechado e sua proposta é ser algo como um catalizador de experiências.

O decrescimento não é uma doutrina unificada. Vívidas tensões entre o jornal La Décroissance e o atual comitê de redação da Entropia acompanharam a emergência desta revista teórica. A criação do PPLD não foi unânime, para dizer o mínimo, e desde o início havia tensões no núcleo de direção. Desacordos sobre o uso do termo 'decrescimento' como palavra de ordem ou como título de programa político. O "decrescimento da pegada ecológica”, adotada pelos Verdes [partido verde], não tem o mesmo impacto do que simplesmente "decrescimento"; trata-se, na verdade, de uma escolha muito diferente. Outros preferem o pós-desenvolvimento, outros ainda evitam slogans (Sylvia Perez-Vitoria) e outros preferem decrescimento sustentável (Vincent Cheynet et Bruno Clémentin).

FLIPO, 2007.

Para ficar mais claro como o decrescimento oscila entre ser um conceito e ser um método, podemos comparar sua história àquela do movimento anti-publicidade francês. Yvan Gradis foi responsável por criar vínculos entre associações ligadas às questões da sociedade 
do consumo e contra a publicidade (inclusive internacionais), e também caracterizou práticas individuais $^{57}$, como escrever em propagandas afixadas na rua ou no metrô, como "antipublicitárias”, ou seja, atribuindo um sentido político específico a ações cujas motivações poderiam ser as mais diversas. Em suma, Gradis conseguiu "transformar, re-etiquetar esses gestos singulares em ações do repertório anti-publicitário" (DUBUISSON-QUELLIER; BARRIER, 2007). Ao mesmo tempo, a proposta era de difundir tais repertórios por diversos movimentos e entre as pessoas.

A análise de Dubuisson-Quellier e Barrier sugere que a formação e o modo de existir no mundo do movimento anti-publicitário é mediado pela construção de repertórios distanciando-se assim da noção de repertório proposta por Charles Tilly, que entende repertório como uma cultura ${ }^{58}$. Seria um movimento que existe na articulação do repertório, já que as formas de ação não são somente um meio para se fazer a crítica à publicidade e à sociedade do consumo. A mobilização, o levantamento, o estabelecimento de relações e a reorganização de uma série de atividades e grupos passaram a ser central e são o único meio pelo qual a crítica pode existir. Os repertórios de ação deixam de ser exclusivos, pois um grupo pode usar os de outro grupo. É o trânsito desses repertórios que definem um novo registro de ação contestatória (cf. DUBUISSON-QUELLIER; BARRIER, 2007). A noção de repertório deixou de fazer parte apenas do vocabulário do analista para entrar para o centro da existência do analisado, mas de forma revisitada. Trazendo essa problematização para o decrescimento, vê-se que o repertório deixa de ser um conjunto de características culturais de longa duração a partir dos quais os movimentos se organizam e que é visível ao observador externo, para se tornar parte das experiências diárias que constituem o movimento.

Assim como no decrescimento, a atribuição da etiqueta “anti-publicidade” a uma série de ações não resultou em um movimento coeso ou engessado, mas sim reorganizou ações pontuais distribuídas por todo o país, como se formasse um repertório que grupos distintos

57 Práticas individuais são aquelas realizadas por uma pessoa, independemente da presença (ou respaldo) de um grupo constituído. O pertencimento a um coletivo político não é determinante, pois a prática individual é feita conforme as disposições da pessoa.

58 Tilly trouxe a noção de repertório para o campo das análises de movimentos sociais como resposta às Teorias da Mobilização de Recursos (TMR). Estas descartavam do esquema explicativo os conteúdos dos movimentos, tanto as causas pelas quais diziam lutar (que ficavam reduzidas à necessidade de angariar recursos para se reproduzir), bem como as formas de organização. Por meio de uma abordagem histórica, Tilly percebeu que as formas de ação política não são totalmente inventadas por grupos específicos, mas sim são escolhas das maneiras de interagir mais adequadas a seus propósitos, diante de um repertório socialmente definido de possibilidades de ação. 
podem utilizar, deixando espaço aberto para as especificidades de cada grupo ou coletivo. É como se o repertório fosse uma linguagem contestatória partilhada, ou potencialmente partilhada - afinal, uma linguagem não é uma causa, mas um conjunto aberto de signos que podem ser articulados para construir causas e mobilizações diversas. É como se o decrescimento tivesse sido efeito de uma linha que costurou pedaços (coletivos, ideias, conceitos e ações) previamente costurados por outras linhas, de cores diferentes, resultando tanto no esgarçamento como no reforço de antigos pontos, sem, por fim, fazer dos pedaços uma superfície lisa, homogênea e inteiriça ${ }^{59}$.

Mesmo que diversas correntes do decrescimento identifiquem os mesmos eventos como fundantes - o que pode sugerir um conjunto unívoco de situações que constituíram o decrescimento - isso não exclui o processo inverso: diversas associações, coletivos e iniciativas individuais se cruzaram em alguns pontos, entre eles os temas da insuficiência da noção de desenvolvimento, do progresso e do crescimento econômico, bem como dos perigos ambientais e sociais do sobre-consumo. O decrescimento não se construiu, portanto, como um conceito unívoco que posteriormente foi colocado em questão por outros pontos de vista que o disputaram; desde seu surgimento, a questão da multiplicação de pontos de vista já era uma estratégia de existência, um meio para a mobilização política.

Dez anos depois do Colóquio, o decrescimento hoje é concebido como nebulosa: é experimentado, vivenciado no (e analiticamente concebido como) trânsito de pessoas, ideias e ações, as quais circulam por grupos e coletivos diversos que, por sua vez, se dizem afinados com alguma forma de crítica ao crescimento - seja essa crítica formulada na ação cotidiana, seja teórica. Ao mesmo tempo, a estabilização dos elementos convergentes sob o nome "Décroissance" não pode eliminar as divergências que lhes são anteriores, nem excluir a possibilidade de criação de novos pontos de tensão. O formato da marcha seria, por princípio, aberto a essas duas possibilidades simultaneamente, assim como o movimento antipublicidade, que se constituiu em um esforço mútuo de conciliar formas heterogêneas de "ação" e incitar a explosão de novos repertórios anti-publicidade pelo território francês.

59 Embora a formulação do decrescimento nesse registro esbarre inúmeras vezes em sua suposta democratização, no sentido de que o movimento incorpora potencialmente quaisquer coletivos, grupos, pessoas, práticas e ideias que se sintam afins ou que tenham a perspectiva de debate sobre o decrescimento, é impostante levar em conta que o movimento é quantitativamente limitado e é organizado e vivenciado sobretudo por jovens adultos de classe média, com ensino superior. Será discutido ao fim do capítulo as implicações de relações sociais que buscam a forma daquilo que os militantes do decrescimento chamam de nebulosa. 
Podemos pensar que esse projeto de convergência é como uma canalização, que faz transitar coisas, pessoas, ideias e práticas, e não disseminá-las.

A formulação do decrescimento como um movimento nesses moldes é sempre tomada como uma inovação ou uma distinção frente a movimentos de massa ou partidos tradicionais (e o partido do decrescimento tem que promover torções para usar a linguagem da fluidez). Com efeito, uma análise que joga luz sobre o jogo entre a construção de conceitos e a elaboração de um movimento multifacetado não pode tomar como um dado tais relações e transformá-las imediatamente em conceitos teóricos ou em uma ontologia social, mas sim o que está subentendido na recusa de ser um movimento tradicional de um lado e na ênfase na descentralização e nas relações entre coletivos, grupos e pessoas de outro.

Uma leitura inspirada em Bourdieu poderia analisar o decrescimento transformando a nebulosa em um campo de disputa para legitimar projetos políticos. Ao capital social e cultural, poderiam ser incorporados algo como um capital “político”. É assim que procede Emilie Henst (2007) ao estudar a revista Entropia. A autora defende que o decrescimento adquiriu certa legitimidade na medida em que foi encampado por intelectuais, os quais, por sua vez, ao deter capital cultural conferiram autoridade ao decrescimento. Outra leitura nessa chave é feita por Szczpanski-Huillery e Simon-Ekovich (2005) a respeito dos movimentos ecológicos do contexto anti-globalização. Segundo os autores, tanto pequenas publicações como as revistas Multitudes, Mouvements e ContreTemps como grandes associações, Greenpeace e Les Amis de la Terre mobilizam saberes produzidos cientificamente a serviço de suas causas - contra o Estado e as multinacionais - porque o campo da ciência confere legitimidade às reivindicações.

Esse tipo de análise procede como se houvesse uma luta incessante pela busca de um decrescimento mais legítimo, o que certamente ocorreu e podemos afirmar que ainda há disputas em torno da melhor ou mais adequada perspectiva sobre decrescimento. No entanto, isso não anula o fato de que essa disputa aparece muitas vezes como uma recusa à univocidade (mesmo que "apenas” no plano do discurso, como a revista Entropia). E quando se fala em nebulosa do decrescimento, é como se essa expressão desse conta de um "projeto" no qual tal recusa é a forma de "resolver" aquelas disputas que ocorrem como descreveriam os discípulos de Bourdieu. Ou seja, é como se a ênfase na recusa a uma centralização no universo do decrescimento resolvesse relações sociais que funcionam na chave de lutas e 
disputas de capitais. Não se trata, portanto, de ver na nebulosa um argumento falso por trás do qual se esconde a tentativa de “monopolizar” as questões envolvidas no decrescimento, nem de tomá-la como uma verdade estabelecida, mas sim de entender o que está envolvido na construção dessa forma de mobilização.

A forma de questionar o crescimento, o consumismo, a predação do meio ambiente, as contradições do avanço técnico e científico passa pela recusa de movimentos sociais cuja organização não se dava no registro do que os militantes do decrescimento chamam de nebulosa, e tudo se passa como se essa "nova” forma de agir e organizar a mobilização social com vistas a transformar o mundo aceitasse que as tensões e disputas existem (já que tantos intelectuais franceses, de Foucault a Bourdieu, associam a crítica social à explicitação das condições sociais da produção de conhecimentos e do estatuto de verdade) sem ter que superá-la. A grande novidade do decrescimento estaria, pois, em traduzir as disputas (que Bourdieu associa a disputa de capitais) em pontos divergentes que dão existência à mobilização social. Em um processo que dá continuidade à expulsão da luta de classes como motor da transformação histórica dos anos 1960 e 70, a nebulosa como método de ação social expulsa os capitais para que fiquem "apenas” as diferenças ${ }^{60}$.

\section{2. Meios de comunicação}

A recusa de um centro e de um sentido exclusivo para o decrescimento é o meio que se considera mais interessante para agir contra o crescimento econômico, como foi visto até aqui. Ao mesmo tempo, não é suficiente tratar a mobilização como um meio, é também preciso vivenciá-la e experimentá-la, afinal é na vida cotidiana que se pode fazer política e que se pode transformar o mundo, como já diziam os ecologistas políticos nos anos 1960 e 70 . Militantes do decrescimento usam a fluidez do movimento como forma de combate enquanto esta forma se converte também na maneira de viver, afinal não basta enfatizar a necessidade do debate e das diferenças, é preciso vivenciá-las por meio grupos, coletivos e práticas individuais que trazem para o cotidiano do movimento a sua experimentação.

60 Não parece aleatório que haja muito debate e muita inventividade para criar mecanismos de comunicação não-violenta. Balançar as mãos, usar cartões coloridos, fazer circular pequenos objetos são todos métodos para que as pessoas envolvidas nas mobilizações e nos coletivos consigam conversar de maneira horizontal, sem que uma (ou algumas) imponham seu ponto de vista sobre as outras. 
Os meios de comunicação utilizados por militantes do decrescimento (e também por outros militantes, porque são meios que ultrapassam o decrescimento) são ao mesmo tempo método e prática da nebulosa já que são tanto um meio de comunicação e um instrumento para conectar pessoas, grupos, ideias e manifestações, protestos e iniciativas de toda França (e até mesmo de países vizinhos), como também um meio cuja forma é também o fim do movimento. É o “pensar global, agir local” atualizado pela dinâmica nebulosa do decrescimento. O estabelecimento de relações é o caminho para se concretizar um projeto social de decrescimento cuja característica é a manutenção das diferenças e das conexões.

O projeto político do decrescimento não passa apenas por colocar lado a lado as perspectivas distintas: é preciso que se estabeleça algum tipo de relação entre elas. A questão sobre o que é fazer política passa, então, pela potência das relações: como relacionar um partido político com um movimento anarquista, por exemplo? O meio encontrado é a ênfase nos modos de vida: ao mesmo tempo em que todos estão de acordo que é preciso adotar práticas cotidianas e pequenos gestos associados à crítica do decrescimento, os modos de vida não assumem o mesmo significado para cada ponto da nebulosa.

\section{2. 1. Silence e a nebulosa das "alternativas"}

A revista Silence é muitas vezes considerada uma publicação mais interessante do que o jornal La Décroissance porque não seria apenas dedicada à crítica, mas apostaria nas “alternativas”. As pessoas que dizem preferir a revista ao jornal geralmente se identificam como "libertárias”. Kitschelt (1990) define o conceito "libertário de esquerda” por oposição ao anarquismo e também ao socialismo. A proposta libertária concebe uma sociedade igualitária, mas diferencia-se do socialismo porque ali a igualdade seria fruto de autoritarismo $^{61}$. Para isso, as decisões deveriam ser orientadas por valores democráticos, comunitários e de reciprocidade. Ao mesmo tempo em que foge do socialismo, a perspectiva libertária também afirma um distanciamento com relação ao anarquismo, uma vez que este adotaria uma utopia de sociedade fundada em comunidades autônomas e a proposta libertária reconhece o papel das instituições no nível nacional e globalização com a finalidade de criar uma ordem social em sintonia com os ideais libertários.

Além dessas diferenças estabelecidas por Kitschelt, há algumas outras levantadas

61 Esta oposição que a autora diagnostica entre os libertários dos anos 1980 faz ressoar toda a discussão apresentada no primeiro capítulo sobre a relação entre socialismo e ecologia política. 
pelos próprios militantes do decrescimento. Segundo um militante muito crítico ao $L a$ Décroissance, a principal diferença entre anarquistas e libertários diz respeito ao caráter positivo dos últimos: enquanto os anarquistas negam o Estado, as instituições e a ordem existente, os libertários estão engajados na construção de alternativas. O mesmo rapaz avalia que há estratégias de ação anarquistas muito interessantes, como aquelas ensinadas pelo jornal Outrage: para subverter as estradas, "armas usadas pelo inimigo" ${ }^{2}$, são usadas técnicas para passar pelos pedágios sem pagar e sem ser pego, estacionar e não pagar o parquímetro, ou ainda roubar gasolina (OUTRAGE, 2010). Mas é preciso pensar em como vamos viver depois, insistia o militante; se colocarmos abaixo todo um sistema social capitalista, o que teremos no lugar?

As afinidades entre militantes libertários e decrescimento, que dentre outras maneiras se expressa na simpatia pela revista Silence, passam pela proposta de uma mobilização social que não seja nem anarquista nem socialista e que difira dos programas dos partidos políticos, mas que seja aberta e sem uma orientação exclusiva. O ponto no qual ambos se cruzam é o discurso da coexistência "horizontal" de alternativas sociais, mediada por relações "humanizadas" (ou vice-versa, relações humanizadas mediadas pela horizontalidade), defendida e supostamente experimentada por aquilo que se chama de nebulosa do decrescimento.

A partir de um levantamento dos índices dos números desde 1994 da revista Silence, podemos identificar basicamente duas formas de apresentar as alternativas: por temas e por regiões. No primeiro caso, as alternativas são como soluções para setores específicos, como educação, economia solidária e finanças, construção e habitação, proteção social, cultura e entretenimento, agricultura orgânica, comunicação e mídias alternativas, energia, transportes, saúde e pequenos gestos (por exemplo, pratos alternativos). Essas alternativas podem aparecer em pequenas colunas na seção “Alternatives”, onde são divulgados eventos, anúncios, revistas e livros recém-lançados e notícias e atualidades. Também podem estar em dossiês sobre um tema, como habitação. Neste caso, iniciativas em diferentes partes da França ou mesmo em outros países são apresentadas como espécie de um mapeamento, juntamente com reflexões sobre a necessidade de novas formas de habitar e ocupar o espaço.

A edição de outubro de 2009 foi dedicada a iniciativas de habitação participativas. O

62 O jornal identificava em alguns números o que chamava de armas do inimigo, como telefone celular. 
objetivo deste número era "fazer circular informações e experiências para que novos projetos se beneficiem das práticas dos antigos” (BERNARD, 2009a, p. 4). O primeiro artigo do dossiê sugere que vivemos em uma sociedade que nos ensina desde crianças a importância da propriedade privada e o individualismo. Por meio de outra apreensão do habitar, seria possível propor e experimentar outros projetos de sociedade. Há projetos em curso que levam em conta o meio ambiente, como as eco-vilas, mas também aquelas cuja preocupação é “social”, de viver comunitariamente, como o cohousing ${ }^{63}$. Depois desse artigo, que termina por apresentar diferentes versões de habitação participativa, seguem dois textos com “exemplos" de iniciativas que funcionam há algum tempo, um na Dinamarca e outro na França.

Na Dinamarca, o projeto nasceu em 1988 a partir de um debate em uma universidade sobre a construção de casas de acordo com o desenvolvimento sustentável. Na ocasião, o governo local vendeu um terreno para o grupo que, com "sua própria experiência e seus próprios meios” (THOUVENIN; DELESTRÉ, 2009b), construiu cinco casas com sistema de isolamento térmico feito por papel reciclado ou palha, tijolos de terra, etc. Outros grupos se formaram posteriormente e ocuparam o terreno com casas construídas de maneiras distintas. Hoje, cada um desses grupos organiza-se internamente e a cada mês todos se reúnem para tomar decisões por consenso ou por voto. Neste caso, a “alternativa” é uma palavra que sistematiza uma série de elementos: desde a decisão de elaborar o projeto até a forma de gestão do coletivo de casas, passando pelos materiais de construção, pela inexistência de uma diretriz que novos moradores devem obrigatoriamente adotar.

O modo como essas informações são apresentadas apaga intencionalmente outros elementos que poderiam estar presentes, como a origem das pessoas que foram construir suas casas nesse local. Esse obscurecimento é uma maneira de tornar manifesto o projeto de um movimento que se pretende múltiplo e aberto a todos. Se o texto dissesse, por exemplo, que os moradores atuais são professores universitários, cientistas ou que são oriundos de determinados centros urbanos, ou ainda que são de elevada classe social, teria que acionar um argumento "em contraposição" para mostrar que o que importam não são essas especificidades, mas a possibilidade de sua coexistência. A coabitação descrita dessa maneira é como que um projeto que faz as divergências que se dariam em outros planos desaparecerem ali e serem controladas no interior das reuniões e decisões coletivas.

63 Cf. THOUVENIN; DELESTRÉ, 2009a. 
As alternativas podem aparecer isoladamente, como no artigo sobre o La Rôtisserie, um pequeno restaurante parisiense localizado em uma rua que no inverno é ocupada por ricos “descolados” que frequentam os restaurantes caros de estilo "étnico-bio-chic” e no verão, quando essas pessoas estão viajando, é ocupada por migrantes que vivem em péssimas condições (COLLOGHAN, 2008). O La Rôtisserie é considerado “alternativo” por seu modelo de funcionamento, que se opõe aos outros restaurantes do bairro, aos preços altos, à especulação imobiliária e à segregação urbana.

Na hora do almoço, o restaurante é “autogerido” pelos sete funcionários, e salvo a garantia de preços baixos e da manutenção do restaurante aberto nos horários prédeterminados, tudo é decidido coletivamente, inclusive quem trabalha em qual dia da semana para compor equipes. À noite, quando não funciona como restaurante, o La Rôtisserie transforma-se em espaço associativo: cada noite é de responsabilidade de uma associação diferente que queira levantar fundos para a sua atuação militante, ou como espaço para reuniões. Entre as associações, há uma AMAP (Association pour le maintien d'une agriculture paysanne), bem como reuniões de vizinhos ou associações do bairro. Também já passaram pelo espaço inúmeras associações com finalidades as mais diversas, que vão de ajuda humanitária em países pobres até grupos anti-publicidade. As duas únicas exigências do espaço para os coletivos é que ofereçam preços baixos caso forem vender produtos e que promovam atividades abertas.

A segunda maneira que a revista encontra para apresentar as alternativas é agrupandoas por localidades geográficas. Desde 1997 são publicados os “números regionais” nos quais são elencadas as diversas alternativas em curso em cada parte da França. Fillieule (2007) chama a atenção para a "fragmentação" tanto espacial quanto temática dos movimentos ecologistas na França desde a década de 1990. Os levantamentos feitos pela Silence são tentativas de religar os fragmentos por meio da descrição das relações (existentes ou possíveis) entre eles, com o objetivo de ultrapassar ou superar o caráter potencialmente pontual dessas mobilizações, para que não ocorram somente em torno de um conflito específico em curso envolvendo a população local - formas de mobilização que ficaram conhecidas como NIMBY (Not in my backyard) protests.

Para levantar as alternativas de cada lugar, pede-se com antecedência nos editoriais que as pessoas enviem contribuições e indiquem aquilo que elas acharem pertinente para o 
levantamento ${ }^{64}$. O número de janeiro de 2006 foi dedicado às alternativas em Ariège e HautesPyrénées: “O dossiê desse mês é 'transversal' na medida em que tentamos fazer uma lista tão completa quanto possível do que se passa em Ariège e Hautes-Pyrénées” (SILENCE, 2006). As duas cidades são habitadas majoritariamente por pessoas que chegaram depois dos anos 1970 e que colocaram fim ao abandono que os vales dos Pirineus sofriam progressivamente ao longo do século XX. Esse fluxo de pessoas vindas de todas as partes da Europa trouxe, segundo o editor da revista, uma "mistura cultural” que contribuiu com as "múltiplas redes locais” já interconectadas (BERNARD, 2006). Aqui, novamente, aparece a questão da origem das pessoas envolvidas com as alternativas locais, e o que é enfatizado na revista é a possibilidade de a diferença coexistir como "mistura cultural”.

A partir de um editorial em particular, pode-se perceber que o objetivo da revista não é montar um quadro de alternativas aleatórias, mas compor feixes de relações (a partir de conexões já existentes ou apontando as possíveis). Na opinião do editor chefe da revista, elencar projetos de agricultura biodinâmica e orgânica, escolas, associações dedicadas à produção de energia renovável (dentre elas, uma que explora tecnologias de tração animal), manifestações culturais e uma série de outros coletivos (tudo isso seguido do contato telefônico ou endereço) é uma forma de apresentar o decrescimento que se realiza de maneira concreta, por oposição aos partidos tradicionais ${ }^{65}$ que se restringiriam à questão da desertificação e não se engajariam em alternativas reais (ou seja, os partidos levantam problemas, mas não dão a devida atenção às práticas existentes e engajadas em elaborar soluções), como postula o próprio editor da revista.

O levantamento e apresentação de associações, iniciativas e práticas coletivas é sempre acompanhada de textos que problematizam e justificam seu caráter alternativo. A estratégia textual usada em grande parte dos artigos ou dossiês consiste em partir de um “diagnóstico” do contexto e, então, se for o caso de dossiês regionais, indicar quais são aquelas que se relacionam os problemas levantados em cada local. No caso do restaurante parisiense, ele era qualificado como “alternativo” por uma série e fatores: por oferecer preços baixos em um bairro de preços altos; por ser aberto para moradores locais que são geralmente

64 Entre os locais explorados, alguns deles são: Loraine (n. 397), Nord-Pas-de-Calais (n. 325-326), DrômeArdèche (n. 318-319), Poitou-Charentes (n. 312-313), Bouches-du-Rhõne/Vaucluse (n. 305-306), FrancheComté (n.298-299), Aquitaine (n. 291-292), Isère (n. 285-286).

65 Os partidos políticos contra os quais muitos militantes do decrescimento constroem esse tipo de crítica são o Partido Socialista Francês e o Partido Verde. 
excluídos do comércio elitista do bairro; por dar espaço a associações que não têm sede própria; por ser um espaço autogerido enquanto esse não é o modo de funcionamento do comércio local.

Uma alternativa é, então, uma iniciativa que, em sua concretização material, pretende se distanciar do contexto a partir do qual se constitui. Mas o distanciamento não é o único critério para definir uma alternativa: uma iniciativa deve carregar um componente político, deve questionar esse contexto. A alternativa é como uma “extensão do político para o seio da vida privada” (BERNARD, 2009b). Se não há uma dimensão política, dizem muitos militantes que apoiam a revista Silence, a ação pode acabar reduzida a uma iniciativa individual e até mesmo "liberal"; e não basta, por outro lado, insistir demasiadamente na dimensão política e nos questionamentos de antemão, porque o resultado será a falta de pessoas para colocar o projeto na prática (afinal, poucos serão os que se identificariam integralmente com o projeto).

A proposta de sistematizar iniciativas locais foi também levada a cabo por um jornalista ex-integrante da Silence na pequena editora Le P'tit Gavroche, fundada em 2006. Esteban Montoya relata que não se interessava tanto por ecologia até conhecer a revista Silence, quando era estudante. A partir de então, começou a se engajar pela causa ambiental e escreveu para a revista em no início dos anos 2000 sugerindo que fosse feito um "número regional” sobre o local onde morava. Ele se engajou no levantamento das alternativas locais e depois de alguns anos mudou-se para Lyon e trabalhou como funcionário assalariado da redação da revista até sair e criar sua própria editora.

O primeiro guia publicado pela Le P'tit Gavroche em 2006 era sobre meios de comunicação alternativos, “Devenons des médi@s alternatifs! Guide des médias alternatifs et des sources d'informations différentes”. Em 2011 foi reeditado com as atualizações necessárias e logo o guia se esgotou. O objetivo da publicação era mostrar que seria possível se informar por meio de fontes ditas independentes, tanto com relação à publicidade quanto a políticos. Foram enumerados mais de 600 contatos de “mídias alternativas”, como revistas, rádios livres, canais de televisão associativos, sites e blogs.

O segundo, "Le Rhône en alternatives”, foi escrito em 2008 para ser um "guia de iniciativas ecológicas e solidárias”. Foram retomados levantamentos prévios publicados em números da Silence sobre a região, e uma equipe de dez pessoas trabalhou voluntariamente no 
levantamento e organização dos dados que entraram para o livro. Na ocasião do lançamento, um blog divulgava o evento, que ocorreria no bar De l'Autre Côté du Pont, em Lyon, e destacava que a intenção da equipe que organizou o guia era de tornar conhecidas e dinamizar as alternativas existentes, bem como favorecer a emergência de novas iniciativas e novas redes (PONCET, 2008).

Em 2008, foi publicado o "Travaillons moins \& autrement: guide de formations alternatives", produto de uma pesquisa sobre trabalhos e empregos não tradicionais que poderiam interessar a jovens que terminam o ensino médio. Segundo Esteban, o guia partia da necessidade de apresentar aos estudantes alternativas profissionais existentes em todo território francês, mas que nem sempre eram de conhecimento de todos. Na ocasião de uma “expedição” da revista Silence, dia em que voluntários podem contribuir com a revista dobrando e etiquetando aquelas que são enviadas para assinantes, um dos redatores da revista sugeriu um tema para um próximo número: as profissões do futuro. Se queremos outra sociedade, dizia, em que as pessoas vivam de outra maneira, é preciso pensar nos trabalhos que deverão existir para esse mundo funcionar. Um dos exemplos que o rapaz oferecia era “mecânico de bicicletas” em estradas, já que as pessoas deixariam de usar carros para viagens longas e seria cada vez mais necessário que existissem pessoas dedicadas a essa tarefa.

A perspectiva trazida pelo guia é complementar a essa, não por criar profissões futuras, mas por dar atenção a ofícios já existentes que não seriam orientados pela lógica de trabalhar mais para ganhar mais - que acaba gerando uma dependência do dinheiro e do trabalho. O guia apresenta "uma multidão de formações alternativas que existem hoje, em vários domínios, para viver e agir de outra forma, privilegiando o respeito ao planeta, aos seus preciosos recursos e assim o respeito aos seres humanos” (ALTER INITIATIVES !, 2009). O guia apresenta áreas de atuação, como arquitetura ecológica, agricultura orgânica, economia social e solidária, energias renováveis e economia de energia, pedagogias diferentes, resolução de conflitos por meio da não-violência, alimentação saudável, artesanato; também oferece conselhos práticos sobre onde procurar oferta desse tipo de trabalho, sobre criar as próprias atividades e associações e ainda redes, sites, revistas e livros que podem ajudar. Os 400 exemplares publicados esgotaram muito rapidamente e, embora queira relançar, a editora não disponibiliza de mão-de-obra suficiente para a atualização necessária.

Por fim, foi publicado um guia um sobre festivais alternativos, o Festivaltern', no qual 
constam atividades ligadas à agricultura camponesa e orgânica, artes de rua e circo, arquitetura ecológica, artes, literatura e contos, artesanato, quadrinhos, cinema e filmes, comércio justo, dança, ecologia, economia social e solidária, energias renováveis, festivais off, feiras orgânicas, fóruns sociais, artes da terra, livros, marionetes, música, fotografia, solidariedade, teatro e viagens. Este último guia está em processo de atualização e o objetivo é relançá-lo em formato de bolso para que as pessoas possam andar com ele quando estão viajando, por exemplo, explica Esteban. A diferença desse guia é que ele é organizado por tema e por data, e não por região, para que as pessoas possam organizar-se para ir, de acordo com o mês do ano.

Esteban, que coordena sozinho a editora Le P'tit Gavroche, explica e vivencia sua profissão-militante e seu dia a dia como um emaranhado de redes. Para conseguir levantar recursos para novos guias ou para atualizar os existentes, ele entra em contato com as alternativas para ver se elas têm interesse em fazer um anúncio. O festival Primevère, por exemplo, estará no guia de festivais, mas se os organizadores tiverem interesse, relata o responsável pelo guia, podem pagar uma quantia em dinheiro para a editora para terem um espaço extra (de até mesmo uma página inteira), com o conteúdo que quiserem. Além disso, Esteban procura as pessoas engajadas em uma vasta rede de contatos para, então, poderem “conjuntamente”, levantar as alternativas para os guias. Quando um guia está sendo montado, ele não trabalha sozinho, mas também não exerce a função de um chefe que coordena a equipe; à medida que os redatores do guia têm suas redes próprias, que por sua vez abrem para novas redes, são capazes de fazer um bom levantamento. Para falar de si mesmo e da forma de funcionamento da editora em particular e do decrescimento em geral, Esteban aciona uma literatura ampla da sociologia sobre mobilizações sociais em rede e está sempre em busca de formas de sistematizar e compreender as redes de movimentos sociais (tais como softwares para representar graficamente as relações entre os coletivos, iniciativas e grupos mapeados pelos guias).

Esteban e a editora não são uma referência conhecida, ou pelo menos são citados espontaneamente nas conversas que circulam entre militantes. A falta de estrutura (financeira sobretudo) que impossibilitaria a publicação de reedições dos guias também expressa o relativo isolamento de Esteban, no sentido de que a editora não conta com uma grande massa de apoiadores que estejam presentes no cotidiano. Mesmo que esse isolamento não seja 
absoluto e que algumas pessoas conheçam os guias, tudo indica uma certa fragilidade da $L e$ P'tit Gavroche como coletivo com vistas a promover algum tipo de transformação social. Contudo, nas falas de $\operatorname{Esteban}^{66}$, a tarefa de levantamento de informações (para a qual consegue mobilizar uma série de voluntários pelo país) e a sistematização dos dados em guias que visam criar relações entre pessoas de diversas partes da França são como que uma tentativa de dizer que é possível transformar a realidade social a partir de formas de ação pequenas e localizadas desde que a dispersão seja mediada. A reivindicada força política (ou do potencial transformador) dos guias e da revista Silence residiria não apenas em levantar uma série de exemplos a serem seguidos, mas em tornar visíveis possíveis relações entre eles, e potencialmente estender uma série de questões e soluções pelo território francês, europeu e até mesmo intercontinental.

A noção de ação política assume, dessa maneira, um caráter específico que, embora seja considerado "novo”, já estava presente na proposta “pensar global, agir local” dos anos 1960 e 70. Diferentemente dos partidos políticos, os guias, a revista e as alternativas locais seriam formas de conciliar pequenas ações espalhadas pelo país sem a necessidade de uma coordenação centralizada, garantindo aquilo que chamam de “autonomia” para os grupos e coletivos. É justamente a ênfase na construção de relações que não implicariam na circunscrição de um movimento social (ou em um partido, como disse Michel Bernard da Silence), mas sim uma nebulosa por todo o país que torna decrescentes a revista e a editora Serge Latouche (2009) associou o termo "relocalização” ao decrescimento e hoje esse termo circula como um argumento que justifica ao mesmo tempo que explica a chamada nebulosa.

Decrescimento para a revista e para a editora não é apenas um conjunto de conceitos, nem um conjunto de críticas. Dessa perspectiva, o decrescimento só existe nas redes de alternativas que se espalham por todo o país, mesmo que na produção biodinâmica de queijo, ou na construção de habitações coletivas não se fale em decrescimento. A prerrogativa da prática de alternativas com relação à fazer a crítica social implica que nem sempre tenha que se mencionar o termo decrescimento (ou qualquer outro que possa aparecer), como se a crítica ao crescimento estivesse contida no restaurante em Paris, nas alternativas em Hautes-Pirénées e nas profissões militantes.

66 Comunicação pessoal, 2011. 


\section{2. 2. Redes de comunicação}

Os meios de comunicação, como a revista e os guias, parecem ter um papel importante na constituição da mobilização do decrescimento, menos no sentido de fazer circular notícias e informar militantes do que como canal por meio do qual se estabelecem as relações que são essenciais do ponto de vista da formulação do movimento. Nesse sentido, outro instrumento usado frequentemente por militantes que se identificam com o decrescimento são alguns sites bastante conhecidos, como o Rebellyon ${ }^{67}$ e o Agenda Lyon.

Em Lyon estas páginas virtuais são usadas pelos coletivos, associações e grupos militantes (sejam ecologias, anarquistas, feministas, socialistas, etc) como ferramenta de divulgação de eventos e atividades. Ambos funcionam anonimamente, sem que uma pessoa que acesse os sites conheça seus criadores e gestores. O Agenda Lyon é bem simples, trata-se de um calendário em que as datas são preenchidas com atividades diversas, as quais são postadas pelos próprios organizadores, como está escrito no cabeçalho do site (que se é fixo e aparece em qualquer link): "bem-vindo a AGENDALYON, o site que faz um repertório dos eventos militantes de Lyon e da região metropolitana. Essa agenda é original porque é coletiva: cada coletivo é que inscreve os eventos”.

A ênfase nos grupos (e não em indivíduos que podem se cadastrar) é uma maneira de garantir o o caráter social da mobilização, no sentido que mesmo que associação formada por poucas pessoas $^{68}$ não fica restrita a seu pequeno interior ao estabelecer relações. Isso não significa que ela cresça (poucas são as que tem esse objetivo de fato) e sim que ela justifique seu caráter político pela extensão de si por meio dos contatos. Cada unidade cadastrada pode disponibilizar seus contatos (e-mail, site, telefone e endereço) e uma pequena descrição.

A busca no site pode ser feita por datas ou por coletivo (por meio de um índice alfabético). Clicando sobre o dia, a pessoa interessada pode saber quais os eventos programados, o local e a hora; a busca por coletivo mostra suas informações e os eventos passados ou futuros por ele organizados. No sábado, dia 25 de fevereiro de 2012, encontra-se o evento "Vélorution” ${ }^{69}$, que ocorreria às 15 horas na Place de la Comédie. O link dá acesso a

67 Jogo de palavras com "rébellion” (rebelião) e Lyon.

68 Além da Le P'tit Gavroche, uma série de outras associações é pequena mas opera pela mesma lógica de sua extensão virtual por meio de sua atuação. É o caso do jornal La Décroissance, da loja 3 p'tit pois ou da associação Les Compostiers, as quais serão apresentadas adiante.

69 A Vélorution (jogo de palavras com "vélo" [bicicleta] e "révolution" [revolução]) é um encontro mensal de ciclistas que pedalam coletivamente para protestar em prol da utilização da bicicleta como meio de transporte. Na página que descreve a Vélorution não há endereço ou telefone porque nada relativo à 
página exclusiva do evento, com sua descrição: "Passeio de bicicleta festivo e militante. Fantasias, bicicletas bizarras, patins, correndo, sonorizações... todo mundo é bem vindo(a), desde que não seja motorizado(a). No fim do passeio, propomos um lanche e cada um pode levar algo para beliscar ou para beber” (VÉLORUTION, 2012). Já o link do coletivo leva à página na qual está descrito encontramos uma descrição e o site - no caso. Os encontros são registrados no site mensalmente, desde 2006.

O Rebellyon é outro site que também disponibiliza uma agenda diária com eventos alternativos em Lyon, mas diferencia-se do AgendaLyon por publicar textos de temas diversos, como notícias que não saíram na grande mídia, ou mesmo discussões, reflexões e questionamentos. Alguns dos assuntos comentados por militantes são oriundos dessa fonte, como quando ocorreu uma marcha organizada por coletivos anarquistas contra grupos

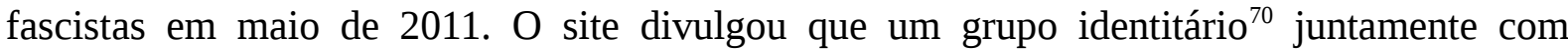
neonazistas de Lyon estava organizando uma manifestação no dia 14 de maio contra a comercialização da carne vendida pelos imigrantes árabes em seus pequenos comércios. Vários coletivos estavam chamando, pelo site, uma contra-manifestação reivindicando o fechamento do ponto de encontro dos neonazistas no bairro de Gerland, o fim das agressões provocadas por neonazistas, contra a transformação de Lyon em um "laboratório do ódio”, a recusa da propagação do ódio e violência racista e xenófoba e em defesa dos direitos humanos iguais para todos e todas ${ }^{71}$. Além do chamado para a contra-manifestação, o texto discutia o paralelo entre a recente visibilidade e crescimento do movimento fascista em Lyon e políticas radicais contra imigrantes ilegais e promoção oficial de discriminação a árabes e negros (REBELLYON, 2011b).

O formato dos sites, das revistas e guias sugere não apenas que haja uma troca efetiva entre grupos e pessoas diversas, mas que o argumento da troca de diferentes entrou para o primeiro plano da cena da mobilização coletiva em Lyon: ela não é um produto neutro, decorrente de um desenvolvimento racional das tecnologias de telecomunicação. Ela é

organização do evento funciona fora dos encontros mensais. O local de onde sai o grupo (que varia a cada mês pois não há filiação) é sempre o mesmo de modo que não é necessário uma organização previa para decidir; o trajeto por onde passarão as pessoas é decidido no ato, embora possa haver alguma proposta já debatida entre pessoas que frequentam assiduamente a vélorution mas que deve passar pelo crivo dos demais presentes.

70 O movimento identitário nasceu no início dos anos 2000 como nova direita, diferenciando-se de grupos nacionalistas porque se identifica como patriota. Os grupos identitários, espalhados pela França, promovem uma série de manifestações contra imigrantes.

71 Para um panorama geral da expansão dos neonazistas em Lyon, cf. REBELLYON, 2011. 
reivindicada, é a forma como se concebem os movimentos e como eles procuram agir: sem centro, em rede.

A internet é muitas vezes considerada a inovação responsável pela restruturação das mobilizações sociais recentes, como se fosse um novo campo de possibilidades tanto no que tange à forma quanto ao conteúdo dos movimentos. Numa perspectiva de longo prazo, que insere as mobilizações sociais em contextos mais amplos, Charles Tilly (2004), que estudou por muitos anos os movimentos sociais, questiona o que chama de "determinismo tecnológico”, ao defender que o uso de telefone celular e da internet apenas teria expandido relações sociais e práticas que já vinham se configurando nas mobilizações do dito mundo globalizado.

Sylvie Ollitrault (1999) procede de maneira similar e defende que a internet apenas potencializou elementos que já estavam presentes anteriormente. Primeiramente, já havia, segundo a autora, uma preocupação em constituir um repertório de ações que conseguisse divulgar as causas para um público amplo e a Internet apenas teria contribuído para a circulação de imagens que já tinham certa importancia. Em segundo lugar, a comunicação foi de fato favorecida pelas possibilidades trazidas pela internet, mas a difusão não se universalizou, já que buscar questões ecológicas e militantes na rede supõem um conhecimento prévio desse universo, por menor que seja ele. Por fim, a internet parece ter colocado em rede movimentos aparentemente desconexos (como demonstram as longas listas de links de movimentos "amigos"), mas na realidade, a Internet só provocou tal efeito por estar afinada com um o questionamento territorial (sobretudo de limites nacionais) que já encontrava força entre os movimentos.

As ponderações de Ollitrault são bastante interessantes e de fato permitem questionar o papel redentor geralmente atribuído à internet. No entanto, a busca pelas “origens”, ou pela dimensão precedente - se as “causas” ou os “instrumentos” da luta - parece ser uma tarefa árdua e não traz no horizonte qualquer perspectiva de solução. Ao identificar uma relação entre o uso intensivo de meios de comunicação com um novo modelo de militância, Ollitrault defendia que o primeiro produzia uma nova forma de ativismo de engajamentos de curta duração (um indivíduo pode engajar-se em diversos movimentos de uma só vez e circular sem os constrangimentos da pertença exclusiva). Contudo, quando olhamos para os dois sites e para o uso que se faz da internet nos circuitos do decrescimento, percebemos que a internet 
não assume apenas um papel de suporte, de instrumento para mobilização - que é o que parece orientar tanto a perspectiva “apaixonada” quanto a “crítica” sobre seu uso. Além de mecanismo de comunicação, a internet é um lugar privilegiado para se constituir redes, que é, como vimos, o modo de existência do decrescimento.

Logo, ao invés da disputa pelo elemento que confere a "novidade" aos movimentos sociais de 1990 - a internet, as causas transnacionais ou a globalização? - parece mais interessante ver que essas causas fazem convergir duas tendências: o extrapolamento de territórios previamente estabelecidos, por um lado, e o discurso do duplo processo de aproximar uma infinidade de coisas, e garantir a manutenção das diferenças, sem que ambas entrem em contradição. A partir do momento em que elementos previamente distintos se constituem como convergentes, eles próprios se reconfiguram e assumem novos sentidos diante da emergência de seus produtos. O fato de haver um crescimento considerável de investimentos das associações em comunicação, como arguentam Ollitrault e Esteban, mostra que o uso novos instrumentos colou-se com as “novas” formas de existência dos movimentos.

É importante levar em conta que, apesar do potencial da internet em estabelecer vínculos infinitos, os sites utilizados pelos militantes do decrescimento de Lyon tem limites, uma vez que não divulgam absolutamente todos os eventos da cidade. Os sites, eventos, textos e links que aparecem, por exemplo, no Rebellyon estão em acordo com relação a algumas ideias gerais, mas ao mesmo tempo, as publicações não são produzidas centralizadamente (ou seja, esses temas compartilhados não se consolidam como um programa político unívoco a partir do qual seriam desenhados os textos e os links). É como se o site fosse uma plataforma que permite o trânsito de temáticas que acabam se encontrando em alguns pontos sem que seja necessária uma carta de princípios unificada a qual todos os artigos, eventos e sites relacionados devem se submeter.

Com efeito, há algumas diferenças de perspectivas mesmo entre os veículos de informação cuja forma parece indicar a concretização dos vínculos potencialmente infinitos. Os sites, revistas, jornais e guias são limitados do ponto de vista quantitativos: não são usados, lidos e alimentados senão que por um grupo restrito de pessoas ${ }^{72}$, e essa restrição passa também por um corte de classe social afinal quem pode comprar mensalmente revistas que vão de 5 a 10 euros e acessar a internet são os setores de classe média. Ao mesmo tempo,

72 A tiragem da revista Silence varia mensalmente de 6000 a 7000 exemplares. 
há uma delimitação que poderíamos chamar de temática. Nas palavras de um militante de Lyon, a nebulosa do decrescimento é marcada pela diferenciação entre atuação nas cidades e no campo. A revista e os guias priorizam atividades, eventos, coletivos e associações que ocorrem em cidades pequenas, enquanto os sites (e na pequena agenda publicada no jornal $\mathrm{La}$ Décroissance) são majoritariamente utilizados pelos movimentos da cidade de Lyon.

Paralelamente às leituras que exaltam o papel da internet na constituição e organização dos movimentos sociais, os militantes do decrescimento fazem outra interpretação que, embora seja crítica, não anula o argumento da potência da rede. Enquanto meio de comunicação, a internet é problematizada por alguns militantes, que defendem seu uso ponderado por razões sociais e ecológicas. Os problemas do computador e da internet seriam os custos ambientais (gasto de energia tanto no uso pessoal quanto em toda rede necessária para manter a internet em funcionamento) e a dependência cada vez maior de ferramentas virtuais culminando em uma possível eliminação das relações sociais. A revista Silence costuma publicar reportagens e dossiês sobre a internet; o Casseurs de Pub e o jornal La Décroissance têm promovido anualmente o Dia sem Monitor (Journée Sans Écran); e muitas pessoas recusam a ter perfis em redes sociais, algumas mesmo não tem endereço eletrônico propositadamente. Em suma, embora os militantes do decrescimento não recusem a visão de que a internet potencializa a mobilização social descentrada, e de que a internet seja uma ferramenta que assegura a forma nebulosa de existir, defendem uma moderação de seu uso acompanhada da circulação de outros meios, como os jornais, revistas e guias para evitar danos sócio-ambientais envolvidos na utilização da internet.

\section{2. 3. La Décroissance: a crítica como ação}

Por ter o nome de La Décroissance [O Decrescimento], o jornal de Vincent Cheynet aparenta ser, no mínimo, representativo do movimento, quando não é tomado como “o” jornal do decrescimento ${ }^{73}$. Mas este "equívoco" não ocorre apenas por pessoas que estão fora da nebulosa. Uma vez que Cheynet teve um importante papel no desenvolvimento da mobilização em prol do decrescimento e que seu jornal tem no nome um artigo definido ( $O$ Decrescimento), muitos militantes fazem questão de chamar a atenção para o fato de que não se trata de um centro nem de uma referência mais importante do que as demais na nebulosa.

73 O slogan da publicação é: “La Décroissance, o jornal da alegria de viver”. 
Um dos (então) três funcionários do jornal ${ }^{74}$ diz que o jornal não tem muito a me oferecer e que, para entender o que é decrescimento, outros grupos também poderiam ser convidados a darem seus pontos de vista ${ }^{75}$. O próprio Vincent Cheynet compartilha dessa ideia e diz que seu jornal não tem nenhuma pretensão de representar o movimento e que, por isso, tudo o que o jornal entende por decrescimento é aquilo que sai publicado mensalmente.

Um militante que afirma ter boa circulação entre os diversos grupos do decrescimento explica que essa é uma estratégia de Cheynet para não ter que expor em público seus desentendimentos. O que interessa de sua fala não é, entretanto, aquilo que ela esconde, mas sim que o argumento usado, qualquer que seja o motivo, de que o decrescimento é maior do que o jornal, que recupera o argumento da ausência de um núcleo central do qual emanam orientações teóricas e práticas.

Uma série de pessoas, ao falar sobre decrescimento, mobiliza listas de referências: “para saber o que é decrescimento, procure o coletivo de compostagem urbana”; “você precisa conhecer a 3 p'tit pois que acabou de inaugurar”; “sábado tem uma ação do déboulonneurs, muitas pessoas ligadas com o decrescimento estarão presentes”. Nessas falas, ora o jornal La Décroissance não é sequer mencionado, ora é reconhecido como parte do decrescimento, mas nada além disso. Esse tipo de fala que aciona algo uma espécie de agenda de contatos é análogo ao funcionamento dos guias, da revista Silence e dos sites no que se refere à recusa de unificar o decrescimento.

A usual avaliação crítica que se faz do jornal não decorre, consequentemente, de sua suposta pretensão de monopólio do decrescimento, afinal as pessoas engajadas com o $\mathrm{La}$ Décroissance têm pleno conhecimento de que uma série de coletivos espalhados pelo país se dizem decrescentes e sabem que a disputa no sentido oposto não seria bem sucedida. Outro argumento que se utiliza com frequência para desqualificar o jornal é seu excesso de crítica.

O La Décroissance, na explicação de muitos militante, faz rir porque promove um estranhamento sobre coisas que seriam naturais para muitas pessoas - inclusive para militantes. ${ }^{76}$ A ironia dos textos e das imagens são consideradas formas de escancarar as

74 Em 2010, além de Cheynet, havia duas mulheres e um homem que participavam do jornal como assalariados; em 2011, uma das mulheres saiu e ficaram apenas os três anteriores que cuidam de tudo, desde a pauta até o envio do número e a festa de confraternização a cada "expedição".

75 Comunicação pessoal, 2010.

76 Pode-se interpretar o riso de outra maneira, embora não seja esse o argumento dos militantes que tocam no assunto: faz rir aquilo com o que o leitor ou leitora se identifica, e não aquilo que ele estranha. $\mathrm{O}$ riso decorreria da identificação, por parte dos militantes do decrescimento, entre as imagens e a realidade 
ambiguidades do crescimento, do consumo de massas e da publicidade. Uma tema com a cabeça enfiada em um amontoado de produtos (lata de Coca-Cola, símbolo do Mc Donalds, embalagem de sucrilhos, relógio de pulso, carro, máquina fotográfica, computador, etc) acompanha o título do número 60 (junho de 2009): “A recusa da realidade”. Em poucas palavras e com uma imagem, o jornal quer dizer que tudo aquilo que parece ser nossa felicidade, todas as mercadorias de aparência agradável (como no desenho), são, na verdade, uma forma de aniquilar o pensamento, de esconder os malefícios que trazem consigo.

Quadrinhos que narram a história de um militante chato, pequenas crônicas sobre um psicanalista maluco, reportagens sobre a vida ecologicamente incorreta de personalidades que se dizem ecologicamente corretas (são os chamados écotartufes), são todas tentativas de subverter até mesmo o subversivo, como a imagem da capa do número 86 (fevereiro de 2012). Movimentos contrários às políticas de austeridade na Europa lançaram o slogan "somos 99\%”, referindo-se à população que sofre as decisões do 1\% da população que detém o capital e o poder político. O La Décroissance inverte a crítica: "Nós somos 1\%, eles são 99\%”, é a frase que sobrescreve o desenho de uma mulher remando um pequeno barco com a palavra “Decrescimento” escrita no casco, em uma maré de carros que vai na direção contrária.

Em todo número, há uma seção intitulada "As porcarias que não compraremos esse mês", na qual um pequeno texto sobre determinado objeto desfila seus problemas ou consequências sociais e ambientais negativas. O banho de chuveiro foi eleito como "porcaria” uma vez que um dos jornalistas do La Décroissance (que não assina a reportagem) começou a fazer esportes antes do trabalho e como a sede do jornal não tinha chuveiro, passou a usar um balde para se lavar todos os dias. Daí concluía: banho é desnecessário, é possível ter higiene sem chuveiro ou água corrente. Aspirador de pó, chocolate e até mesmo bicicleta são utensílios que apenas aparentam facilitar e alegrar nossas vidas, insistem os artigos, mas eles são prejudiciais do ponto de vista ecológico, e é possível viver sem eles.

Quem se diz favorável ao decrescimento concorda com esse tipo de crítica e com a necessidade de dissociar consumo e produção de felicidade e liberdade (como aparece no jornal). O que se torna um problema que é caracterizado como "excesso de crítica” ou de posição "radical” não é, portanto, decorrente dos questionamentos mais gerais que o jornal formula. Um dos pontos de excesso aparecem quando, por exemplo, as críticas feitas pelo jornal no registro da ideologia (cf. SAFATLE, 2008). 
jornal são estendidas para o “interior” da nebulosa do decrescimento, como aquelas a militantes ecologistas (como a Pierre Rabhi) ou a apoiadores do jornal (como Paul Ariès) ${ }^{77}$.

A avaliação crítica que se faz do jornal não decorre, portanto, nem da pretensão de monopólio do decrescimento, nem das críticas que ele tece ao crescimento. Estes argumentos são usados, na verdade, como subterfúgio para abordar outra questão: a forma de fazer política do jornal é considerada incompatível com a forma nebulosa de existência do decrescimento por aqueles que se dizem libertários. Muitos militantes dizem que o problema não são as críticas ácidas que o jornal faz, mas sim a redução do decrescimento a elas. No colóquio de 2002, a proclamada novidade daquele espaço era conciliar as críticas ao desenvolvimento (e ao neoliberalismo) com propostas de refazer o mundo; se explicitava a conjugação entre negação e proposição.

Mesmo que Cheynet e seus companheiros do jornal tenham uma vida política ativa está sempre envolvido com a dinâmica partidário-eleitoral, organiza eventos como o ContreGrenelle $^{78}$, organiza panfletagem em frente a comícios e eventos de partidos - essa política não é bem vista por não apresentar propostas “alternativas”. Não se trata da falta de ação, portanto, mas da falta de determinado tipo de ação que deve ir "além” daquelas que postulam críticas ao crescimento. Essa é a mesma questão que se coloca para o PPLD e que tenta ser resolvida pela elaboração de um programa que é, ao mesmo tempo, uma recusa de um programa e um conjunto de propostas de fazer circular as ideias envolvidas com o decrescimento e conjugar experiências concretas existentes pela França.

Há quem chame Vincent Cheynet de “republicanismo legalista” (BAYON; FLIPO; SCHNEIDER, 2010) porque já se apresentou como candidato em eleições e participa de ações de desobediência civil com vistas a mudar a legislação - e não subvertê-la, e por isso é

77 Pierre Rabhi, enquanto era integrante do conselho editorial do jornal em 2005, publicou um livro com Nicolas Hulot, considerado um écotartufe por excelência. O jornal então publicou um pequeno texto com muitas críticas ao livro e a Rabhi, que conseguiu depois publicar uma resposta. Em 2011, houve uma nova polêmicas envolvendo Cheynet e Paul Ariés, um cientista político que contribuía mensalmente com o jornal com artigos importantes - que muitas vezes tornavam-se referência entre muitos militantes. A briga foi transformada em história em quadrinhos na edição seguinte a seu afastamento.

78 Entre 2007 e 2012 foram organizados três Contre-Grenelle, que são eventos com formatos parecidos a colóquios, dos quais quais participam personalidades do decrescimento, críticos do neoliberalismo, estudiosos sobre questões ambientais (principalmente energéticas). As falas expositivas são intercaladas com apresentações teatrais de personagens criadas, como Nicolas Bertrand (uma mistura de Nicolas Hulot e Yann Arthus Bertrand, dois "écotartufes” [“ecohipócritas”] que estampam as páginas do La Décroissance com frequência). 
duramente criticado. Uma militante acredita que Cheynet seja capaz de chamar a política em uma manifestação porque ele é, segundo ela, adepto do legalismo e do Estado. Em 2012, o Parti Pour la Décroissance, que se aproximara de Cheynet na campanha do candidato à candidato à presidência Clemence Wittman $^{79}$, publicou um artigo em seu site oficial rompendo com o jornal. As divergências concerniam ao modo como Cheynet enfrentaria as eleições e a démarche partidária de modo geral:

[...] Ele é contra a renda universal e todas as propostas construídas em torno da expressão da gratuidade [referência a um debate proposto por Paul Ariés]. Ele crê em uma tomada republicana do poder que preceda as mudanças. Ele prefere apoiar iniciativas eleitorais individuas, ao invés de construções coletivas de fôlego, que respeitam a diversidade da objeção de crescimento. Tudo isso é seu direito, a não ser pelo fato [...] de vestir sua carapuça de jornalista para fazer uma imagem "coletiva" das decisões que ele tomou unilateralmente. Ele aproveita dessa carapuça para publicar artigos irônicos contra o movimento dos Objecteurs de Croissance [OCs], com o qual ele não partilha dos objetivos e dos métodos. Vincent Cheynet sequer faz esforço para ir ao encontro dos OCs que não concordam com ele. Para ele, não passam de irresponsáveis que colocam o decrescimento em perigo.

PARTI POUR LA DÉCROISSANCE, 2012b.

O discurso que caracteriza o jornal como insuficiente do ponto de vista do decrescimento por seu “excesso de crítica” não é efeito das críticas em si, mas da falta de algo que a complemente, pois segundo muitos militantes, não basta negar o crescimento, é preciso também agir e realizar a negação em ações propositivas. Quando leitores da Silence dizem que o foco do decrescimento apresentado pelo jornal são as grandes cidades, essa crítica é uma variação daquela que diz respeito à falta da abordagem de um conteúdo prático. $\mathrm{O}$ questionamento de modos de vida urbanos (como o uso de carros, televisão e computador), deixaria de fora comunidades e formas de vida para os quais o abandono desses instrumentos e aparelhos já é uma questão superada.

As entrevistas transcritas na seção intitulada Simplicidade Voluntária no jornal La Décroissance apresentam para o público leitor pessoas que adotaram formas de vida alternativas, na maior parte das vezes em pequenas cidades no interior da França. Entretanto, na opinião de um leitor, o padrão de edição das entrevistas sugere um ideal específico de decrescimento, que enfatiza sempre os mesmos aspectos urbanos, mesmo quando os

79 Em 2011, Clement Wittman viajou pela França de bicicleta para conseguir as 500 assinaturas de prefeitos necessárias para se tornar candidato à presidência da república e o jornal foi um importante meio de divulgação de sua campanha. 
entrevistados vivem em outra realidade. Nestas sim, dizem muitos militantes (que preferem a Silence), o decrescimento “se realiza” de verdade.

Dizer que o jornal é excessivamente crítico e chamar a atenção para algo que lhe falta (as alternativas locais) significa que a perspectiva que se diz libertária, que propõe relações sociais “não hierárquicas”, “autogeridas” e que não são limitadas por um programa político exclusivo, é também excludente em certo sentido. Grupos, coletivos e pessoas que são de alguma forma associados a formas de ação consideradas superadas pela nebulosa autogestionária (como o "legalismo" de Cheynet) são tomadas como relativamente incompatíveis com o decrescimento.

O discurso da mediação de conflitos (que acompanha a forma nebulosa do decrescimento) é também colocada em xeque quando grupos de direita se dizem decrescentes $^{80}$. Esse é um assunto pouco comentado e do qual militantes fogem quando questionados. A fragilidade de uma mobilização como a do decrescimento aparece neste silêncio, afinal quando o movimento que enfatiza as relações depara-se com algo com o qual não se almeja ter relações, como lidar diante disso? O jornal e Cheynet ocupam um lugar parecido, que é aquele da mobilização política que é considerada insuficiente, legalista, excessivamente crítica, com o qual as redes não querem tecer relações. Mas o movimento não postula isso de maneira nenhuma, do contrário seria necessário explicitar (ou construir) linhas gerais com as quais Cheynet e seu jornal não se encaixam, o que redundaria em um movimento que vai de encontro com a forma libertária ${ }^{81}$.

O jornal e Cheynet estão no limite do decrescimento mas não são expelidos para fora por duas razões. A primeira decorre do papel "protagonista” de Cheynet na história do decrescimento. A segunda maneira de contrabalançar as incompatibilidades é a politização da vida cotidiana entre os companheiros de Cheynet e nas páginas do jornal.

Nos anos 1990 foram realizadas várias pesquisas com militantes de partidos ligados a questões ecológicas e os resultados dos surveys apontam para aquilo que se convencionou

80 Como o partido Le Trèfle, que defende os animais, a natureza e uma dura política contra imigrações.

81 Em uma das primeiras reuniões do recém-nascido grupo "Die em transição", colocou-se uma questão que tomou todo o tempo do debate: dado o formato aberto do grupo (qualquer pessoa poderia participar da forma que quisesse, como e quando lhe conviesse), não seria preciso estabelecer linhas gerais para que novatos soubessem do que se tratava? O grupo de pouco mais que doze pessoas se dividiu: algumas defendiam que sim, para facilitar o desenvolvimento de atividades futuras; outras diziam que isso ia conta a proposta de manter o debate sempre em aberto. Ao fim da reunião, nenhuma decisão havia sido tomada. 
chama de politização da vida cotidiana como elemento fundamental para compreender as mudanças pelas quais o movimento ecológico passava naquele momento. É possível que o recorte empírico das pesquisas deva-se ao fato de a filiação partidária ser, naquele período, a forma mais expressiva de organização e mobilização ecológica, mas este é apenas o ponto de partida. No interior dos circuitos partidários, esferas “tradicionais” de atuação política, a vida cotidiana e os modos de vida não eram apenas um espaço políticos complementar. Ao contrário, nos movimentos ecológicos desde os anos 1960, é mais importante formar um movimento político e cultural do que incitar a filiação partidária (ROUSSELLIER, 1993).

A experimentação social e a ideia subjacente de uma sociedade alternativa sempre estiveram presentes no discurso ecológico. Ideia que rompe com a tradição de mudança social brusca, violenta e hierárquica, se enraíza na cultura política francesa. Para os ecologistas, mais do que uma mudança social por decreto, vinda do alto (de Paris ou do QG do partido), as práticas culturais alternativas devem ser construídas pelos atos vindos da base. A evolução dessa ideia e a prática que dela decorre é aquela de uma imagem revolucionária da mudança social através de uma visão mais pragmática e reformista

PRENDIVILLE, 1993, p. 42

Uma análise comparativa entre militantes dos partidos verdes francês e britânico no fim dos anos 1980 e começo dos 1990, levou Florence Faucher (1998) a concluir que, nos dois grupos, "os militantes consideram as atividades cotidianas politicamente significativas e contribuem para a definição de sua identidade ecológica. A adoção de determinada conduta é uma maneira estilizada e ostentatória de exprimir suas opiniões e seu pertencimento a um grupo” (p. 438). Segundo Roussellier (1993), o militante de um partido verde aplica em sua vida cotidiana os preceitos de sua adesão política: desenvolve, por exemplo, projetos de energia na própria residência, não tem televisão e usa papel reciclado ${ }^{82}$.

Se a politização da vida cotidiana é uma questão que não é exclusiva ao decrescimento, como mostram esses estudos da década de 1990 sobre militantes do partido verdes francês, ela assume um lugar específico agora. O fato de a vida cotidiana tornar-se

82 Nos anos 1990, Sylvie Ollitrault (2001) detectou uma profissionalização, ou uma especialização, entre militantes ecológicos, o que acabou transformando a configuração do movimento ecologista como um todo. Diante da incorporação de elementos do mundo do trabalho e do mundo da ciência na militância, recolocouse uma velha questão da definição da ecologia: defender a natureza "por si" mesma ou trazer a luta em defesa da natureza para a luta por uma sociedade diferente. O que era o ponto de divergência naquele momento é hoje o que configura a inteligibilidade da palavra decrescimento nos mesmos meios (não que o debate anterior tenha deixado de existir, mas no interior do decrescimento, sim). 
esfera de ação política está ligada à nebulosa como método de mobilização, como prática política e também ao conceito de decrescimento. Adotar no dia a dia pequenas práticas de consumo, de trabalho e de lazer são um meio de acessar as questões que o decrescimento levanta sobre sociedade de consumo e outras de ordem mais geral e ao mesmo tempo. Pelos modos de vida se articulam os diversos sentidos da nebulosa e dão concretude àquilo que se chama "nova forma de fazer política".

No projeto de decrescimento do jornal, a vida cotidiana assume um papel específico. O exercício diário de viver de outra maneira é chamado de simplicidade voluntária e, nas palavras de Paul Ariès (2005), o nível da ação individual é apenas um dos níveis do decrescimento. A adesão a uma vida simples é um requisito, mas não esgota o decrescimento, nem é o principal meio para se transformar a sociedade; deve-se lutar coletivamente e politicamente (por vias partidárias). Um militante diz que desde a década de 1960, muitas pessoas adotam modos de vida alternativos mas ao invés de articularem a vida pessoal com um projeto maior de transformação social, acabam entrando para uma lógica religiosa que é reacionária .

As duas falas apontam para uma noção de decrescimento que seria mais politizado do que apenas adotar atitudes incomuns consideradas alternativas. O decrescimento lhes aparece como que uma maneira de estabelecer conexões entre tais atitudes para elevá-las ao nível de potencial transformadoras sociais, sem ter que passar pelas formas mais conhecidas de movimentos sociais. Ao escrever sobre a simplicidade voluntária e sobre a relação entre vida cotidiana e ação política, o La Décroissance se insere no decrescimento novamente pois é como se abrisse espaço, por meio dessa relação, ao estabelecimento de relações não hierarquizadas e descentralizadas entre coletivos dispersos na nebulosa, os quais fazem a passagem dos pequenos gestos para a transformação social.

\section{3. Consumo político, trocas humanizadas e produção justa}

Pequenas lojas de produtos orgânicos, coletivos anti-publicidade, restaurantes, são todas formas de se colocar em prática a crítica ao crescimento, dizem muitos militantes. Colocar em xeque aquilo que muitos denominam sociedade do consumo passa por adotar novos padrões de consumo, como comprar somente aquilo que é necessário; escolher marcas 
e fabricantes que não poluam e que priorizem formas de produção socialmente justas.

Assim como a revista Silence e os guias, ou os sites, a passagem da ação e da escolha individuais para uma crítica ao crescimento é realizada pelo estabelecimento de conexões entre as pequenas iniciativas locais, por vezes isoladas, como se as relações estabelecidas entre elas restituísse à mobilização uma dimensão social que não apareceria apenas pelo ato de consumir. Muito se diz, por exemplo, dos modos de vida alternativos que são incorporados pelo capitalismo verde: comprar orgânicos no Carrefour e não receber propagandas na caixa de correio podem ser apenas um estilo de vida como qualquer outro, um novo público para o qual o capitalismo se adapta e tenta vender seus produtos “alternativos”.

O passo além que é preciso dar é análogo àquele representado nas páginas da Silence e dos guias alternativos, ou dos sites de Lyon. Paralelamente ao mapeamento feito por esses meios de comunicação, há um grande esforço por parte dos coletivos de se articularem, seja por meio da compra e venda de produtos orgânicos, seja por meio da própria organização dos coletivos que cruzam temas diversos.

Lyon é repleta de lojas de rua que comercializam produtos orgânicos, de cosméticos a cereais. Essas lojas geralmente são franquias de grandes cadeias, como a rede cooperativa Biocoop que foi fundada nos anos 1970 para comercializar vegetais e outros alimentos orgânicos e desde então cresceu de tal forma que é possível encontrar suas lojas por todo território francês. Entre as pessoas que, de uma forma ou de outra, estão ligadas ao decrescimento, grandes cadeias de distribuição, mesmo que no registro de cooperativa, não são vistas com bons olhos. Primeiramente, por conta da poluição gerada pelo abastecimento de toda a rede, já que os produtos comercializados são produzidos centralizadamente, implicando grandes deslocamentos; em segundo lugar, dada a extensão da cadeia, nem sempre seria possível ter garantias de que a produção é verdadeiramente orgânica e que os trabalhadores são bem remunerados.

A pequena mercearia 3 p'tit pois foi inaugurada em março de 2010 a fim de oferecer aos habitantes de Lyon uma alternativa ao mercado de orgânicos existente. Os dois responsáveis pela loja ${ }^{83}$ acreditam que, sem dúvida, há uma relação entre decrescimento,

83 Assim como o jornal é responsabilidade de Cheynet, a Le P'tit Gavroche é de Esteban, a 3 p'tit pois é de dois rapazes. Na extensa nebulosa do decrescimento, ações pequenas, levadas a cabo por poucas pessoas, encontram espaço, como que em uma recusa de massificar o movimento. As "ações individuais" que Yvan 
produtos orgânicos e funcionamento em cooperativa da mercearia. Ali são vendidos produtos “orgânicos”, com “pouca ou nenhuma embalagem”, de “produção local” e "socialmente justa”. Cada produto é avaliado de acordo com as quatro variáveis e um gráfico com o resultado final é estampado na etiqueta de preço de toda mercadoria. O comprador jamais encontrará algum produto com as quatro notas baixas, afinal se não são nem orgânicos, nem locais, nem socialmente justos e com muita embalagem, não há razões para serem comercializados ali, explica um dos responsáveis pela loja.

A etiqueta sistematiza graficamente todas as "reivindicações" ou "causas" pelas quais se mobilizam as pessoas engajadas com o decrescimento. Comprar em uma loja como a 3 p'tit pois é como dizer: decrescer não é apenas consumir orgânicos, afinal já há um grande mercado para isso em grandes redes como Carrefour. É preciso comprar produtos que respeitem o meio ambiente e que sejam produzidos de forma humanizada ou, como se diz na França, “socialmente justa”. Grande parte dos alimentos (grãos, queijos, legumes e verduras) é produzida em pequenas cidades próximas de Lyon, favorecendo tanto os deslocamentos quanto a possibilidade de travar relações sociais entre a equipe da mercearia e os produtores. Isso garantiria, na visão da equipe e dos consumidores, tanto a humanização das relações de troca quanto a segurança de ter produtos de qualidade e verdadeiramente orgânicos. Como a mercearia não funciona para obter lucro, os preços não são negociados com os produtores e não se aceita cartão de crédito ou débito como meio de pagamento ("para não dar dinheiro para os bancos", dizem).

O próprio funcionamento da mercearia a diferencia das demais lojas de orgânicos da cidade. A 3 p'tit pois é uma "cooperativa autogerida", de modo que os dois rapazes responsáveis encarregam-se de tudo: desde a procura de fornecedores (que envolve buscar conhecimento sobre as formas de produção dos produtos) até a organização do espaço da loja. A loja se tornou rapidamente um grande sucesso por possibilitar, de acordo com militantes, que se coloque em prática aquilo em que se acredita.

Durante um debate sobre selos ecológicos organizado pela associação Maison Écologie (um espaço que congrega diversas associações, promove debates e eventos e ainda vende produtos orgânicos) estavam presentes representantes locais de certificadoras ${ }^{84}$ famosas

Gradis canalizou também sob a rubrica “anti-publicidade” também ressona essa relação entre o particular e o universal que o decrescimento propõe estabelecer de modo peculiar.

84 Instituições responsáveis por atribuir selos diversos, sobretudo certificação de orgânicos e de produção 
na França como Nature et Progrés e um dos dois responsáveis pela 3 p'tit pois. Algumas mulheres não conheciam ainda a loja e ficaram entusiasmadas com a iniciativa da etiqueta e com a existência de mais um lugar para comprar produtos orgânicos, diferentes dos utilizados por elas mesmas (com grande lamento!) para fazer os bolinhos oferecidos no final do debate.

A 3 p'tit pois surgiu também, como relatou um dos responsáveis pela loja, com o objetivo de facilitar a vida das pessoas que consomem esse tipo de produtos. Por toda a França há muitos pontos de venda de cestas de alimentos que funcionam no sistema de AMAPs (“Associations pour le maintien d'une agriculture paysanne”): associações que fazem a mediação entre uma rede de produtores locais e consumidores, levando kits de frutas, verduras, legumes, ovos, pães, queijos e geleias para pontos pré-estabelecidos da cidade (como um cinema de filmes alternativos, ou uma biblioteca) onde os assinantes pegam semanalmente seus alimentos. O pagamento é semestral e o valor varia de acordo com a quantidade e o tipo de produtos que se quer. O sistema de assinatura permitiria um planejamento dos produtores, evitando desperdício e garantindo a sustentação da agricultura local, explica um vendedor de cestas.

Embora haja muitas pessoas que comprem os produtos das AMAPs, alguns militantes manifestaram preferência pelo sistema da loja porque se não há possibilidade de estar presente no dia e na hora marcada para retirar o kit da semana, não se pode adquiri-lo em outro momento e nem reaver o dinheiro. Além disso, algumas pessoas relataram que acham o preço alto e preferem comprar os produtos da pequena loja.

Há outra pequena mercearia em Lyon chamada De L'Autre Cotê de la Rue que funciona seguindo os mesmos princípios da 3 P'tit Pois: não aceita cartão, dá preferência a produtos locais e com pouca embalagem; cobra a embalagem dos produtos a granel ou deixa à disposição dos clientes saquinhos e vidros reutilizados; acrescenta um pequeno valor ao preço dos produtos que chegam diariamente apenas com a finalidade de levantar recursos necessários para manutenção do espaço e pagamento de funcionários. Por fim, a semana de trabalho dos responsáveis pelas duas mercearias é menor do que as 35 horas do restante do comércio.

Os produtos dessas mercearias não são vendidos apenas para consumo próprio. Assim como essas lojas se constituem como alternativa ao mercado de orgânicos, que cresce cada

socialmente justa. 
vez mais na França, alguns bares-restaurantes foram criados com a mesma finalidade. O Le Court-Circuit e o De l'Autre Côté du Pont são dois espaços que oferecem refeições no horário do almoço e petiscos e bebidas à noite, preparados com ingredientes oriundos das duas mercearias. Ambos são frequentados por militantes do decrescimento, mas não exclusivamente, sendo ponto de encontro de ativistas de diversas causas (ou apenas de amigos de ativistas).

O nome "Le Court-Circuit” (“O Curto Circuito”) é uma forma de publicizar o modo de funcionamento do restaurante: além de comprar produtos produzidos no entorno de Lyon, conseguiu cativar um público do bairro, fazendo com que do começo da produção ao consumo final, não haja grandes deslocamentos. Guillotière é um bairro relativamente simples, habitado em grande parte por franceses descendentes de árabes e negros. Os baixos preços dos apartamentos (e a facilidade de locomoção na região) acabam também atraindo estudantes e jovens já formados que se mudam para Lyon para trabalhar.

Os cooperados do Le Court-Circuit tinham a finalidade de estabelecer ligações mais profundas com o bairro. Um dos cooperados dizia que estava em um espaço privilegiado porque era um dos poucos da cidade onde se podia conhecer quem mora no entorno, sobretudo, pessoas mais pobres e mais velhas (que não frequentam os espaços de jovens "bobos"85). Para expressar essa "diversidade", o Studio Kobra foi convidado para pintar a parede externa do Le Court Circuit em abril de 2011 e foi pedido que Eduardo Kobra e seu companheiro de trabalho Agnaldo Brito fizessem um painel que representasse o bairro.

Um arquiteto francês que viajara a São Paulo a trabalho conheceu o trabalho de grafitti da equipe de Eduardo Kobra. Como Lyon é uma cidade conhecida pelas pinturas na empena cega, esse arquiteto e outras pessoas envolvidas com projetos de urbanismo na cidade acharam que seria interessante trazê-los para produzir um mural no bairro em que o bar se localiza. O bar, recém-inaugurado, aceitou imediatamente a ideia e se ofereceu para hospedálos e fornecer o material para pintar um mural com a "cara" de Guillotière. Esse mural, que ficaria na parede voltada para uma praça e para o jardim, tinha o propósito de retratar as

85 "Bobo" é uma abreviação de "bourgeois bohême" ["burguesia boêmia"] que é usada pelos militantes de forma pejorativa para caracterizar pessoas que se dizem preocupadas com o meio ambiente mas que não passariam de um setor da burguesia que não milita por nenhuma causa. São pessoas definidas como aquelas que "apenas falam e não fazem nada", por oposição aos ativistas engajados. A questão de classe propriamente dita, que é acionada em outros momentos para definir os "bobos" não é mencionada como um elemento de distinção entre os "burgueses boêmios" e os "militantes”, afinal estes últimos também integra a classe média. 
diversas etnias que ocupavam o bairro.

O discurso da diversidade do bairro (que não é apenas um conjunto de falas, mas é também uma composição de ações e práticas) não é apenas uma constatação da heterogeneidade social que compõe o entorno do bar-restaurante. Considerando que o Le Court-Circuit está inserido de alguma forma nos circuitos militantes que buscam "novas" formas de agir e transformar o mundo, a ênfase na diversidade é a ênfase na relação entre os diferentes, que aparece como o ponto chave da mobilização social que prescinde de um centro, de uma univocidade. A representação gráfica não era, portanto, uma tentativa de um retrato fiel do bairro ou do bar, afinal apesar da ênfase nos moradores mais pobres, não são estes que frequentam o espaço diariamente para consumir produtos orgânicos e ouvir músicas. O mural do Estudio Kobra é, então, como uma imagem utópica cuja ênfase não recai sobre as partes diferentes retratadas, mas sobre a possibilidade de colocá-las juntas sem transformá-las em um. A representação da diversidade do bairro ressoa a forma nebulosa do decrescimento, as alternativas locais da revista Silence e também aponta para uma concepção do social na qual o importante é a extensão das conexões, dos pontos de cruzamento entre pessoas e grupos que, sob outro registro de sociedade, ficariam separados e viveriam em contradição ${ }^{86}$.

No dia da inauguração do mural, Eduardo Kobra e Agnaldo Brito, não só estavam satisfeitos com o trabalho, mas também encantados com o modo como foram recebidos. "Em São Paulo, a gente fica sozinho pintando em avenidas grandes, ninguém nem olha para nossa cara", disse Kobra. Em Lyon, não receberam pagamento, ficaram hospedados na casa de pessoas que ofereceram suas casas, ganharam a tinta, havia gente disponível o tempo todo para resolver problemas que surgissem, inclusive pessoas que falavam algum português. Mas, mais do que isso, a relação que os franceses e francesas tentaram estabelecer com os brasileiros passava pela celebração, pela “convivialidade” (a referência a Illich não é fortuito).

Tudo o que fazia com que os grafiteiros relembrassem o tempo em que desenhavam clandestinamente nos muros (a pintura em Lyon não foi aprovada pela prefeitura; não receberam pagamento; não estavam lá como artistas contratados por uma empresa) era, na visão das pessoas envolvidas naquele evento tanto um meio para transformar as relações sociais quanto a própria imagem de uma sociedade alternativa. Assim como o conteúdo do mural, a forma pela qual ele foi produzido remetiam a uma imagem de sociedade na qual as

86 Como ocorre com os imigrantes na França. 
relações sociais são “comunitárias”, mediadas pela festa, pela transformação de contradições em diferenças.

A busca de "humanização" das relações de produção, de comercialização e de trabalho tornam-se índices do caráter político das mercearias, bares e restaurantes alternativos de Lyon. Militantes escolhem-nos porque, diferentemente de outros comércios locais ${ }^{87}$, realizariam práticas sustentáveis e sociais. Além de comprar produtos orgânicos produzidos nas redondezas, militantes ainda argumentam que têm a oportunidade de estabelecer laços de amizade com os produtores que vão frequentemente entregar carregamentos e frequentar espaços de sociabilidade agradáveis - o episódio do mural é expressivo nesse sentido. Uma mulher que só faz suas compras nas duas mercearias conheceu um dos produtores que vão até a De L'Autre Côté de la Rue entregar mercadorias enquanto estava no local. Tinham um conhecido em comum e a conversa foi até a noite, quando tudo estava muito agradável e os recém-apresentados haviam se tornado amigos. Tudo isso, explicava a jovem, em oposição às grandes cadeias de distribuição que, segundo pessoas envolvidas com o circuito alternativo de alimentos orgânicos, deixam de ser mediadoras para orientar toda a produção e lucrar.

Os estudos relativamente recentes sobre "consumo político" ${ }^{88}$ insistiam na necessidade de olhar para os "valores não-econômicos” que começavam a circular entre consumidores como um elemento importante para transformar a esfera do consumo em esfera de ação social e política (BOSTRÖM et al., 2004). As campanhas de boicotes a certos produtos, que se tornaram ferramentas bastante utilizadas tanto para manifestações contrárias às empresas produtoras desses produtos (como boicote a Shell ou a Nike) como forma de oposição a decisões governamentais no fim dos anos 1990, bem como os buycotts (incentivo ao consumo de produtos específicos, como orgânicos) pareciam ser elementos fundamentais para renovar a compreensão sobre participação política (STOLLE; HOOGHE; MICHELETTI, 2005).

A dimensão do consumo entrou definitivamente para a agenda de diversas

87 A rede L'Eau Vive, por exemplo, comercializa muitos dos produtos industrializados disponíveis no 3 p'tit Pois ou no De l'autre côté de la rue, como cremes, shampoos e produtos de limpeza, mas só são frequentados por militantes em caso de emergência. A rede Carrefour também vende produtos alimentares orgânicos, mas dificilmente os militantes compram em supermercado.

88 A expressão “consumo político” ganhou força com pesquisas realizadas na Escandinávia com vistas a apreender fenômenos como os boicote, "buycotts" e abaixo-assinados que foram considerados novos instrumentos políticos em um contexto em que as instituições democráticas pareciam perder o apelo social, nos anos 1990. 
mobilizações e a partir de então, surgiu um novo problema: como identificar se o consumo é politizado ou despolitizado? Militantes não hesitam em desqualificar como "não-politizadas” pessoas que escolhem os mesmo produtos nos mesmos lugares que os primeiros por razões de saúde, por exemplo. Claire Lamine (2008), que escreveu um livro sobre as AMAPs, identificou três “formas de engajamento". Primeiramente, o engajamento mínimo, quando o consumo dos orgânicos distribuídos pelas associações se dá por razões de qualidade dos produtos - "são pessoas que usam a AMAP para a saúde ou por curiosidade, mas que não se interessam por outras formas de consumo responsável”. Em segundo lugar, há quem busque um consumo local e mediado por relações familiares, e “o engajamento consiste no desenvolvimento de relações interpessoais entre consumidor e produtor” (idem). Por fim, há os "mais engajados", para quem os produtos são ao mesmo tempo uma forma de se colocar “do lado” dos agricultores e um ato “consumo cidadão”. Mas, em sua visão, pouco importa se quem compra é muito ou pouco engajado por duas razões: o objetivo das AMAPs é que os pouco engajados se engajem cada vez mais, e um número grande de adesões visibiliza o movimento.

De uma perspectiva supostamente mais neutra (cf. STOLLE; HOOGHE; MICHELETTI, 2005), o consumo é classificado como político quando envolve não apenas boicotes, mas também a aquisição de certos bens e serviços pelo desejo de mudar as condições sociais ou por motivações éticas ou políticas. O consumo política ou eticamente orientado, quando frequente, tende a se tornar um padrão de comportamento.

Há ainda outra forma de responder à questão de como definir quais os limites do consumo político. Ao buscar compreender por que os próprios consumidores consideram suas práticas de consumo importantes para o engajamento, Florence Faucher (1998) percebe que o componente político está na passagem do universal para o particular. Considerando que “a ecologia é uma ideologia política que se pratica na vida cotidiana” (p. 449) e que os ecologistas dizem-se mais avançados politicamente por buscarem uma conciliação entre os princípios que defendem e a experimentação cotidiana desses princípios, consumir produtos orgânicos ou vegetarianos é uma forma de incorporar a reflexão e o engajamento em favor de um certo tipo de agricultura. Consumir um produto “verde” é “esverdear” a si mesmo.

Em todas essas versões de análise e reflexão sobre o consumo político, a intenção 
subjetiva se sobressai, como se o mercado, as formas de dominação e os mecanismos de poder fossem por ela afetados. É como se as pequenas ações levassem à reorganização concreta da produção, distanciando-a minimamente da reprodução capitalista. Ao mesmo tempo, há quem esteja refletindo sistematicamente sobre a mediação entre produção e consumo, com o objetivo de dar um passo além dos estudos sobre consumo político. Dubuisson-Quellier e Lamine (2004) tentam dar um passo adiante dos estudos sobre consumo político ao incorporarem aquilo que militantes do decrescimento iluminam, a relação entre consumo e produção. As autoras postulam uma diferença entre o consumo político e ações de produção e distribuição alternativas. O primeiro faria do mercado um instrumento, um mediador para manifestar uma causa política. Como diz Faucher (1998), o consumo de produtos orgânicos é a "tradução" de uma escolha refletida e de um engajamento em favor de um certo tipo de agricultura. Já as segundas se dão no interior do mercado, com vistas a transformá-lo. "A articulação do político e do econômico nas relações mercantis passa pela recomposição dos espaços de negociação, de decisão e de escolha entre produtores e consumidores, acerca das propriedades desses sistemas” (DUBUISSON-QUELLIER; LAMINE, 2004, p. 145).

A "redefinição" da política por meio da questão do consumo corresponde à transformação da mobilização social em termos mais gerais, como o método de ação que interliga pequenas associações, coletivos, pessoas sozinhas, e que faz do decrescimento um movimento "em nebulosa”, distinto de um "movimento social” ou de um partido. Na medida em que o decrescimento se constitui como nebulosa, as relações iluminadas deixam evidente a impossibilidade de separar “consumo político” de um lado e a produção de outro. Ao mesmo tempo, a forma que o decrescimento assume estabelece uma relação peculiar entre consumo e produção. A escolha pela compra de determinado produto é um meio para fazer uma crítica (à agricultura, ao latifúndio, aos danos provocados pelos agrotóxicos, às decisões unilaterais, etc), mas é também um fim, pois é uma das facetas de uma relação de troca alternativa, a qual, por sua vez, implica uma relação de produção alternativa. Isso significa que a nebulosa não explicita relações dadas (como se fosse uma leitura de uma realidade concreta), mas é uma forma específica de tentar estabelecê-las de modo “alternativo” às relações que existem na sociedade de crescimento ou na sociedade de consumo (a depender do ponto de vista a nomenclatura varia).

O problema de muitas análises - militantes e não-militantes - é que o particular é 
eleito como a nova esfera de atuação política por excelência, desconsiderando justamente o modo como um movimento em nebulosa, como o decrescimento, explica e vivencia a relação entre particular e universal. $\mathrm{O}$ engajamento pessoal interfere diretamente em questões de ordem global, afinal a escolha da mercearia onde se compra os produtos e a própria escolha de orgânicos não é apenas "um ponto de vista”, mas uma forma de colocar em relação sistemas de produção, circulação e consumo alternativos. O engajamento entre os militantes do decrescimento parece extrapolar as considerações sobre consumo político: não consomem apenas como um "boicote" ou uma "crítica" ao mundo em que vivem, mas ao formular lojas que funcionam no registro da economia solidária, ao criar espaços de sociabilidade entre consumidores (e produtores), ao recusarem cartões de crédito e débito, é como se estivessem realizando essa outra sociedade, como se estivessem pondo em prática o decrescimento - e não apenas dando notícias de sua possibilidade de existência.

\section{3. 1. Borrando a publicidade}

A escolha por produtos orgânicos, de um lado, e a produção deles, por outro, são duas faces da "nova forma de fazer política” que são, mesmo que implicitamente, complementados pela crítica às formas de produção e consumo vigentes. Afinal, se produzir e consumir orgânicos localmente de forma cooperativa é uma "alternativa”, alternativa a quê?

O déboulonneurs de Pub é uma rede de coletivos espalhados pela França que se mobiliza contra a publicidade e contra a sociedade do consumo. Embora nem todos os integrantes do coletivo sejam favoráveis à ideia de decrescimento, o grupo costuma ser indicado por militantes da nebulosa do decrescimento porque se opõe àquilo que é fundamental para a manutenção do crescimento econômico, os padrões de consumo.

A publicidade é onipresente: anúncios em postes, em pontos de ônibus, mensagens repetidas ao longo das calçadas nos painéis giratórios [...], colada em ônibus, táxis, metrôs, estações de trem, nas estradas, deixada às toneladas em nossas caixas de correio, [a publicidade] pipoca a cada 20 minutos nos rádios e na televisão, mais páginas de propaganda do que de artigos em algumas revistas e jornais, animações chamativas e intrusas na internet... Mais um setor de nossa vida no qual nossos ouvidos, olhos, nosso olfato são solicitados com o objetivo único de nos fazer comprar objetos inúteis, nos fazem abrir crediários sem necessidade e que nos endividam mais e mais.

DÉBOULONNEURS, [S.d.] 
Hervé Kempf, jornalista do Le Monde, foi convidado para depor, em 2010, a favor dos seis déboulonneurs processados desde 2008 por uma ação em seis anúncios na avenida Champs Élysée em Paris. Em sua fala no tribunal, articulou o movimento anti-publicidade a um problema maior, que é o capitalismo. Kempf falou muito sobre o papel da publicidade na crise ecológica, uma vez que ela incita a consumir sempre mais. Posteriormente, em uma reunião aberta para discutir o andamento do processo, o jornalista usou o alemão Herbert Marcuse para explicar que a mídia é o controle do capitalismo.

Em 6 de março de 2010, ocorreu um ato de barbouillage dos déboulonneurs de pub. No ponto de encontro marcado, a praça da Midiateca em Lyon, havia uma grande quantidade de pessoas, mesmo embaixo da neve que caía. A razão para a presença numerosa era que desde 2008 nenhuma ação desse tipo ocorria na cidade. Um dos mais antigos militantes do grupo explicou que o intervalo de dois anos era decorrente da instabilidade do grupo no sentido de que os participantes estão sempre se renovando, porque muitos mudam de opinião e se desligam do grupo. A fluidez, a possibilidade de entrar e sair e contribuir com o que for possível, que é uma prerrogativa não só do déboulonneurs mas de praticamente todos os coletivos que integram o decrescimento, é também a causa da fragilidade dos movimentos ${ }^{89}$ neste caso, foram dois anos sem atividades; no caso da editora Le P'tit Gavroche, é a falta de recursos para a reedição e reimpressão dos guias.

Entre os presentes no dia do evento, havia uma bicicleta com um carrinho e vários instrumentos, material da "Batucada Militante” (nome brasileiro, diziam alguns), grupo de percussão formado para animar manifestações e eventos militantes. Os ensaios da bateria ocorriam semanalmente em um squat chamado La Friche RVI, uma antiga fábrica de caminhões da Renault que fora ocupada irregularmente por pessoas que realizam trabalhos diversos (quadrinhos, oficina de bicicleta, esculturas, etc) ${ }^{90}$.

89 Essa fragilidade não é exclusiva do contexto francês. A Ação Global dos Povos no Brasil, que seguia um tipo de organização análogo ao do decrescimento, não conseguia ser bem sucedida devido à falta de comprometimento dos militantes, como relata um antigo participante. Aquilo que parecia dar o tom totalmente revolucionário no interior da organização da mobilização social (a ausência de uma organização minimamente centralizada) era o seu fracasso. "Havia uma rádio livre de Florianópolis que, em suas reuniões autogestionárias, fechava a grade de programação, distribuindo os horários às pessoas voluntárias que fariam os programas. Não era incomum alguns pegarem os horários mais disputados e não aparecerem no dia e horário combinados. Quando cobradas, as pessoas colocavam-se como vítimas do autoritarismo dos companheiros, reivindicando sua “liberdade” de faltar (sem avisar, é claro)” (CORRÊA, 2011).

90 No fim de 2010 houve um incêndio no prédio e os moradores não conseguiram apoio para continuarem no local. Não se sabe ao certo se o incêndio foi proposital, já que estava em curso um processo para expulsar os 
Muitos dos participantes eram antigos integrantes do Déboulonneurs que agora apoiavam a causa e as ações, mas não frequentavam mais reuniões; participaram também pessoas engajadas em coletivos diversos ou que, mesmo sem participar ativamente de nenhum coletivo, circulavam entre eles e aderiam a várias causas. Logo um grupo se destacou no centro, formando um pequeno círculo em torno de um rapaz que falava em um megafone. Ele dava coordenadas e anunciava para o público quem ficaria responsável por cada tarefa, entre elas intervir sobre os painéis publicitários (“barbouillher”) e receber a polícia.

Barbuiller é borrar. Todos que que estavam ali esperava o momento de escrever em cima dos anúncios com o objetivo de "borrá-los" em sentido metafórico. As pessoas não estavam embaixo da neve para que a polícia viesse prendê-las, mas para "deixar uma mensagem nos painéis publicitários”. E em caso da chegada da polícia, o que pode ocorrer já que trata-se de uma ação irregular, a orientação geral é que não se resista porque, no caso de um julgamento, os déboulonneurs poderão “defender os espaços públicos usando o aparato da justiça”. Assim seria possível inverter a situação em uma eventual intervenção policial: enfrentar o poder entrando nele e colocando questões a partir desse lugar interior que os acusados passam a ocupar. Na compreensão e motivação de algumas pessoas, a polícia é imprescindível para poder dar continuidade ao processo de questionamento; já outras acreditam que ela pode aparecer ou não, mas o objetivo principal é deixar visível um questionamento e um estranhamento sobre a publicidade para pessoas que circulam nas ruas. Costuma-se definir essa lógica como “desobediência civil”.

No megafone também eram apresentados os papéis que seriam responsabilidade de cada membro do coletivo. Depois de nomear cada participante, o rapaz do megafone anunciou o coletivo, disse que se tratava de um “ato de desobediência civil não violento”. Se a polícia viesse não era para ninguém resistir, nem espectadores nem pichadores, nem mesmo se os últimos fossem presos. Ao se apresentar publicamente essas funções, marcava-se quem estava dentro e quem estava fora da ação de barbouillage propriamente dita. Ao mesmo tempo, o fato de ser uma ação pública implica que quem está fora é imprescindível para o sucesso do protesto contra a publicidade. Muitas pessoas presentes eram simpatizantes, antigos participantes do coletivo ou mesmo integrantes que não seriam responsáveis pela ação. Pedestres também eram o alvo do protesto, afinal a mensagem sobre os painéis deveriam ser

coletivos do local. 
vistas.

Depois dos avisos, o batuque começou dessincronizado enquanto as pessoas começaram a andar em direção ao lugar onde estavam afixados os painéis alvo da ação. A marcha era silenciosa apesar do som dos instrumentos e das vozes que cantavam fora de sincronia "La pub tue, la pub pollue” [“A publicidade mata, a publicidade polui”]. Dois quarteirões depois da concentração estavam duas grandes estruturas de metal afixadas em um prédio, com propagandas que trocavam a cada dez segundos e uma pequena plataforma para realizar manutenção em cada uma, onde já estavam posicionadas as duas pessoas responsáveis pela barbouillage.

A bateria continuou tocando até que o rapaz do megafone se posicionou novamente em destaque para pedir que todos cantassem o hino, escrito em um panfleto distribuído para os convidados. O fim da música foi o sinal à mulher e ao homem posicionados nas plataformas: silenciosa e seriamente, ambos viraram as costas para as mais de cinquenta pessoas presentes e começaram a pintar os painéis. Em um, foi escrito "Espace Publicitaire 50 × 70" [“Espaço publicitário 50 x 70] e no outro, “Legitime Réponse 50 × 70” [“Legítima defesa 50 x 70”]. “50 × 70” significa a reivindicação mais elementar do déboulonneurs: limitar o tamanho dos anúncios espalhados pelas ruas a uma área de cinquenta por setenta centímetros, que é o tamanho permitido para propagandas políticas.

O déboulonneur que panfletava confessou aos colegas na reunião que ocorreu dois dias depois para fazer um balanço da ação, que a Batucada era muito animada e ele havia se empolgado, mas teve que se manter sério. “Isso é um ato de desobediência civil”, pensara ele consigo mesmo. Ninguém estava na rua para fazer uma festa, e sim para desobedecer uma lei, concluiu.

Como previsto, a polícia chegou e não houve agitação, nem mesmo da parte dos dois policiais. Eles esperaram dentro do carro no lado oposto do cruzamento e esperaram a ação acabar. Enquanto lá em cima os painéis eram pintados, lá embaixo, passavam alguns pedestres. Um homem com uma menininha pararam olhar e tiraram fotos, interessados. Outros que não paravam também não aparentavam reprovar. Em outras ações menores, é comum que os presentes (participantes ativos do coletivo ou não) conversem com as pessoas que manifestam qualquer tipo de interesse com o olhar. São travadas longas discussões e é muito comum encontrar apoio nas ruas. Mas naquele dia, tudo era silencioso, as conversas 
eram pontuais e atravessadas pelas batidas dessincronizadas que, ao fim da "barbouillage" voltaram a povoar a tarde branca.

Quando os quatro déboulonneurs desceram ao som de aplausos (dois haviam subido ao longo da ação para ajudar), assinaram um documento trazido pela polícia e apresentaram seus documentos de identidade. Ninguém ficou nervoso nem se ouvia qualquer manifestação contrária à presença da polícia. Novos aplausos, estava tudo terminado. O rapaz dos avisos retomou a palavra e convidou todos os presentes a ir para a Maison du Peuple, sede local da Confédération générale du travail (CGT), onde ocorreu uma confraternização.

Em Paris, há também um grupo local do Déboulonneurs, mas na cidade existem outros coletivos que operam “clandestinamente” porque a estratégia de ação não é pública. São pessoas que se reúnem pontualmente para arrancar os anúncios do metrô sem que sejam pegas, ou que andam com chaves para desligar o motor de totens de propagandas giratórias quando ninguém está olhando. Esse tipo de ação pode ser praticada pelas mesmas pessoas que constituem o Déboulonneurs, no mesmo dia em que aconteceu uma barbouillage, mas em nenhum momento eles responderão por tais ações em nome do coletivo.

A mobilização anti-publicidade data dos anos 1990 na França, quando Yvan Gradis, hoje um dos nomes mais conhecidos do Déboulonneurs, publicava o jornal Publiphobe com argumentos muito próximos dos que circulavam na década de 1970: “Os objetos dessa crítica anti-publicitária são tanto o cinismo das estratégias publicitárias, como o caráter alienante da sociedade de consumo, na qual a publicidade constitui uma das formas mais visíveis” (DUBUISSON-QUELLIER; BARRIER, 2007, p. 213). No fim da década, a mobilização antipublicidade tomou uma dimensão coletiva: Vincent Cheynet cria o Casseurs de Pub e uma série de associações se organizam para realizar campanhas diversas e ampliar seu repertório de ação. Entre 2001 e 2003 houve um “pico” de protestos, até que 62 pessoas foram fichadas e processadas de uma só vez em Paris por uma ação em que cada uma levava seu próprio material e pintava o que bem entendia. Entre as processadas, algumas tiveram que pagar uma multa altíssima também por conta de uma série de ações precedentes nas estações do metrô. Os 62 processos levaram a uma divulgação ampla da mobilização anti-publicitária, mas também de um esfriamento das adesões, afinal as pessoas tinham medo de também serem pegas (cf. DUBUISSON-QUELLIER; BARRIER, 2007). 
Em 2005, Gradis criou com alguns companheiros o Déboulonneurs, diferenciando-se dos demais movimentos pela articulação das barbouillages com a “não-violência”. Uma nova militante do Déboulonneurs relatou que seu coletivo rompeu com o Casseurs de Pub em 2006 por conta de um processo contra 35 pessoas. É provável que esta seja uma variação da versão do “Processo dos 62”, e por mais que essa versão não encontre correspondência com outras, a mulher estava chamando a atenção naquele momento para a especificidade de seu coletivo frente a outras possíveis formulações da mobilização anti-publicidade no país: levar adiante os processos e entrar por dentro da justiça para manifestar-se ${ }^{91}$.

A ênfase na não-violência marca ainda hoje as falas dos simpatizantes e participantes do Déboulonneurs. Quando um militante apresenta o coletivo, mesmo que em uma conversa informal, enfatiza-se sempre o método da “desobediência civil” e a "não-violência”, como se esta fosse o elemento que por excelência caracterizasse o grupo. Há todo um cuidado por parte dos militantes que vão participar da ação para não quebrar nada, nem causar danos permanentes: as tintas usadas nos painéis podem sair com água, usa-se giz de lousa para escrever no chão; nos painéis dos pontos de ônibus, não se escreve com spray diretamente sobre eles e geralmente colam-se cartazes previamente confeccionados ou papeis e branco para que os pedestres possam deixar seu recado sobre o anúncio escondido.

A crítica à publicidade geralmente é apoiada por militantes de causas diversas, como as feministas que deixam mensagens sobre os corpos femininos fotografados, articulando as imagens veiculadas pelo sistema publicitário ao machismo e a opressão à mulher. As articulações não são responsabilidade do movimento anti-publicitário por si mesmo, como já fez questão de enfatizar Yvan Gradis, que teme que "a anti-publicidade se dilua em temáticas maiores, que podem alimentar o movimento mas também asfixiá-lo” (GRADIS, 2004). Mesmo que essa opinião não seja consenso e muitos militantes avaliem positivamente o trânsito das críticas ${ }^{92}$, em nenhum momento esse trânsito se converte em uma mobilização

91 Muitos artigos publicados em 2005 e 2006 sobre o Déboulonneurs enfatizavam justamente esse aspecto da não-violência e da desobediência civil (cf. DARRI, 2006).

92 Em 2011, ocorreu em Lyon um encontro nacional do Déboulonneurs no qual essa tensão foi trazida à baila indiretamente. Os militantes mais antigos (entre ele Gradis) tentavam colocar as discussões, fazer reuniões, conversar sobre publicidade, sobre ações, estabelecer alguns pontos comuns. Já os mais jovens (os organizadores do encontro de Lyon estavam no coletivo há poucos anos) não tinham por objetivo fazer reuniões sistematizadas e discutir coisas “sérias” (eles próprios usavam esse vocabulário), mas fazer festas e seções mais descontraídas para promover o convívio e momentos alegres entre integrantes do grupo. O conflito que se instaurou entre os dois projetos, e que resultou no fracasso do encontro já que nenhum conseguiu realizar-se por completo, era também um conflito entre fazer um movimento que se pretende aberto a novas possibilidades (incluindo articulações diversas) ou um movimento com contornos bem 
ampla, restando à iniciativa individual, de cada militante, vivenciar em seu quotidiano a conjugação de lutas.

A falta de sistematização da convergência das lutas é intencional e caracteriza também o decrescimento. Assim como militantes e analistas compreende essa recusa como um forma de ação política, Dubuisson-Quellier e Barrier (2007) defendem que o movimento por si só é limitado porque faltam relações reais com outras mobilizações, sendo responsabilidade exclusiva dos militantes fazer circular os repertórios.

\section{4. Militância e as totalizações parciais}

No decrescimento, a passagem da ação local para a crítica do crescimento seria realizada pelas relações entre consumo político, produção socialmente justa e mobilização anti-publicidade; ou ainda pelo mapeamento de dossiês regionais ou temáticos, pela elaboração de guias. Mas há ainda um outro elemento que toma centralidade no decrescimento por ser responsável por articular os fragmentos sem transformá-los em um movimento único, coeso e exclusivo: a nova forma de militância, que Dubuisson-Quellier e Barrier (2007) chamam de “multi-militância”.

A figura do militante é aquela de um criador de laços sociais, de pontos de ligação que constituem o decrescimento como uma nebulosa (e não como um movimento social, uma grande associação como o Greenpeace ou como um partido político). Uma pessoa que se diz favorável ao decrescimento não apenas lê o jornal e consulta os sites para saber os eventos dos quais participará, mas também circula nas redes de alternativas como associado, apoiador e usuário dos serviços e produtos por elas oferecidos, experimentando seu cotidiano por meio delas, mas também fazendo delas seu cotidiano. Uma pessoa adepta do decrescimento concebe e vivencia sua alimentação e o consumo, seu trabalho, as relações amorosas, toda sua vida cotidiana e seu corpo como um campo de batalha, no sentido de que tudo isso é permeado por injunções culturais, econômicas, políticas e sociais e, por isso, é por meio deles que se deve agir.

Para estabelecer relações entre coletivos, pessoas, ideias e ações, o militante deve circular, e não pertencer a apenas um grupo. Um rapaz em fase de conclusão de mestrado que

definidos que, a partir de então, poderia ser tomado como referência por outros coletivos. 
morava em duas cidades para trabalhar e estudar, lamentava não conseguir se dedicar mais a nenhum movimento em particular. No passado, integrava ativamente o Déboulonneurs, alguns coletivos anarquistas, ia mensalmente aos encontros da Vélorution. Em um momento de reflexão, fez autocríticas severas a sua militância “espetacularizada”, porque apenas aparecia nos eventos públicos, como manifestações, barbouillages sem participar das reuniões e decisões internas. Ao mesmo tempo, ele insistia que seus colegas eram muito menos politizados do que ele próprio porque não adotavam em suas vidas cotidianas pequenos gestos e não se importavam com as relações por detrás desses pequenos gestos. Logo, mesmo que não pudesse se engajar ativamente em um ou mais coletivos, a sua circulação e a presença esporádica em reuniões e eventos garantia-lhe o estatuto de um militante, alguém engajado e politizado.

A circulação de militantes passou a ser de extrema importância para a própria noção de política. Uma militante exemplar é aquela que aparece em diversos protestos e manifestações, mesmo que participe ativamente de poucos ou mesmo nenhum coletivo (frequentar reuniões organizacionais, elaborar as ações, panfletos, enfim, realizar o trabalho diário necessário para manter o coletivo, associação ou grupo $)^{93}$. Grupos pequenos e pessoas isoladas assumem um tom de mobilização política na medida em que são interconectadas, e um dos meios de promover essas relações são os militantes em trânsito. François Schneider e a marcha de 2005 ou os congressos no exterior (em Barcelona em 2010) são dois exemplos de que o deslocamento tornou-se um requisito da vida política porque ele é um dos meios de travar relações e as relações são o elemento central da existência do movimento.

A emergência de uma área de estudos na sociologia dedicada à militância propriamente dita não parece ser, então, um despropósito, considerando que esta passou a ser uma das principais preocupações e tema de reflexões e debates no universo da mobilização política e social ${ }^{94}$. Além disso, diante de uma realidade que não corresponde a movimentos sociais bem delimitados, com contornos e programas políticos definidos, o estudo das mobilizações políticas contemporâneas se voltou para o que parece ser o núcleo a partir do qual se pode compreendê-las, a prática da militância. Não se trata de ver na militância multi-

$93 \mathrm{O}$ trabalhador bem sucedido é aquele que circula, que sabe encontrar as pessoas e conectar empresas, conhecimentos, projetos, construir redes e assim, dar mais lucros para a empresa, explicam Luc Boltanski e Ève Chiapello (2009).

94 Para uma breve revisão bibliográfica do tema (cf. SAWICKI; SIMÉANT, 2011). 
engajada o nó do decrescimento, mas o inverso. O novo sentido da palavra "militância” (frequentar diversos espaços, agir individualmente em consonância com as propostas políticas dos grupos dos quais faz parte) corresponde a uma forma de fazer política que abre mão de totalizações de um lado e de limites de outro.

Os pontos articulados pelos militantes, contudo, são totalmente instáveis. É a presença feminina que garante, por exemplo, que em uma ação de barbouillage sejam registrados protestos contra a opressão feminina causada pelos padrões de beleza veiculados nas propagandas, e não algo como uma carta programa. Talvez, a ausência de mulheres em uma ação acarretasse na ausência desse viés de questionamento. Isso significa que a noção de ação social também é frágil e a passagem da parte ao todo pode não ocorrer se houver, por exemplo, erros de comunicação, ou mesmo se a pessoa responsável por articular dois ou mais coletivos ficar doente.

Fazer da vida cotidiana o locus da ação política não significa, portanto, apenas reciclar o lixo, a reusar a água e comprar alimentos orgânicos. O foco sobre esse sob aspecto se dá paralelamente ao discurso das relações entre pontos dispersos, e a palavra nebulosa que tantas vezes é utilizada pelos próprios militantes para descrever o decrescimento é a maneira de expressar essa forma de mobilização social na qual coexistem as diferenças, sem recair em pequenos coletivos atomizados ou em uma grande massa social.

Nos anos 1970, transformar o corpo, a alimentação, a sexualidade, as relações familiares, a educação, e tantas outras “pequenas” coisas em campos de batalha era uma novidade porque ampliava a noção de ação política para além da atuação no interior dos partidos e sindicatos. Hoje, o consumo é uma dimensão imprescindível para a atuação política militante no movimento de decrescimento, mas não apenas como possibilidade de trazer para a vida individual uma questão social, mas sobretudo porque por meio dele se elabora uma nebulosa, com diversas pequenas ações interligadas, culminando em uma noção de social.

Como diz David Harvey (2012), o primeiro momento foi marcado por um "ataque multifacetado e pluralista às práticas localizadas de repressão” (2012, p. 51), mas não era claro como essas lutas localizadas poderiam compor um ataque progressivo ao capitalismo. $\mathrm{O}$ que o decrescimento e sua forma em nebulosa pretendem fazer é tentar um modo de articulação que realize esse ataque generalizado sem precisar passar por uma superação das particularidades de cada luta. 
A “novidade” desta forma de fazer política consiste na elaboração de uma imagem de mobilização social na qual a passagem dos pequenos gestos para a transformação social não se dá pela construção de uma totalidade, mas pela constituição redes fragmentadas que, em nenhum momento, tem perspectiva de se constituir como unidade. E, mais do que isso, a construção da rede deve ser feita exclusivamente pelos militantes (ou por associações, coletivos), como uma forma de negar a institucionalização de uma totalidade heterônoma. No decrescimento, qualquer totalização só pode ser perspectiva e parcial: só pode se realizar por meio das intenções dos indivíduos autônomos, que circulam e estabelecem conexões ou pelas relações que os coletivos estabelecem entre si, e nunca englobará todo o território, todas as pessoas e todas as coletividades de uma só vez.

As afirmações que povoam o decrescimento sobre a incompletude auto-assumida de cada coletividade e sobre e impossibilidade de universalização apontam para o que se denomina aqui totalidade perspectiva e parcial $^{95}$. A noção sociológica de multi-militância chama a atenção para o fato de que um militante não circula entre diversos coletivos ligados organicamente, mas que a circulação tornou-se o elemento mais importante para a ação política, e que por meio dela esses coletivos não se fundem. Se há alguma totalidade possível do ponto de vista do decrescimento, ela nada mais é do que o produto das relações que os militantes traçam em seus caminhos. A relação entre feminismo, ecologia e crítica à publicidade não é evidente nem imediata: precisa ser construída dia a dia, e cabe a cada militante articular conhecimentos, saberes, repertórios de ação, coletivos, pessoas e associações.

\section{5. A expulsão do outro no “outro possível”}

A atualização das reivindicações e das formas de atuação política dos anos 1960 e 70 pelo movimento do decrescimento que emergiu na década de 2000 revela que os primeiros não fracassaram completamente. Mesmo que não tenham sido bem sucedidos no que se refere a seus objetivos de transformação efetiva das relações de produção e de sociabilidade, a

95 O dossiê de aniversário da Silence (2012) intitulado “L'écologie em 600 dates” recusa enfaticamente traçar um panorama que dê conta de todos os eventos históricos ligados à ecologia e anuncia que são os múltiplos pontos de vista que podem dizer quais os acontecimentos importantes para a sua concepção de ecologia. Por isso, não é apenas o corpo editorial da revista que escreve os verbetes de cada data, mas convidados bastante diversos entre si, como que em uma tentativa de assegurar a diversidade de perspectivas. 
movimentação daquele momento fez nascer o que David Harvey (2012) chama de pósmodernismo. Da ampla discussão apresentada pelo autor, o que parece interessante reter aqui (e que na verdade pode ser tomado como um dos pontos centrais de sua argumentação) é que o projeto moderno, em suas variantes, operava na chave do perspectivismo epistemológico: as diferenças, a fluidez, o fugidio e o fragmento são a forma de acesso ao universal, que é complexo. O pós-modernismo transformou a questão, abriu mão da busca de uma realidade universal, seja subjacente ou na superfície do fenômeno da complexidade e restou neste último como ontologia. Houve algo como um deslocamento do foco, agora para a questão de "como realidades radicalmente diferentes podem coexistir, colidir e se interpenetrar" (HARVEY, 2012, p. 46) ${ }^{96}$.

O movimento de decrescimento, tal como se configura desde os anos 2000, parece portanto atualizar as reivindicações dos anos 1960 e 70 de maneira muito similar ao fenômeno mais geral que Harvey aponta. As pequenas ações e o cotidiano politizado foram o solo no qual floresceu a mobilização do decrescimento que se descreve como uma nebulosa, no sentido de que, por um lado, pretende dar conta de compor uma forma de combater o crescimento e todos os elementos a ele relacionados; por outro, o modo encontrado é aquele que recusa universais, e cuja preocupação central é fazer coexistir as diferenças, sem buscar um contraponto a elas. E soma-se a isso a ênfase na dimensão propositiva, por oposição ao caráter excessivamente crítico (que faz com que o jornal La Décroissance corra o risco de ser expelido do decrescimento, assim como muitas pessoas que “apenas criticam” não são consideradas verdadeiras militantes do movimento).

A crítica à crítica e a ênfase nas relações apontam para um outro elemento que se desdobra das atualizações acima esboçadas. Foi visto que as mobilizações dos anos 1960 e 70 se constituíra por oposição a noções como luta de classes e contradições entre capital e trabalho, expulsando de si a fratura no interior do social, bem como da forma de se conceber a ação política. O decrescimento, trinta anos depois, deu cabo do processo de expulsar o negativo do social através da ênfase nas relações e na possibilidade de coexistência de inúmeros coletivos supostamente diferentes.

96 A discussão de Eduardo Viveiros de Castro $(2008,2011)$ sobre o papel da antropofagia de Oswald de Andrade revela essa transformação do modernismo em pós-modernismo: a antropofagia é uma maneira de fazer a alteridade coexistir e a antropologia deve buscar a compreensão da relação entre perspectivas e não qualquer elemento a elas subjacentes. Este tema será um pouco mais aprofundado no próximo capítulo. 
O grito "um outro mundo é possível", conclamado por pessoas de todo o mundo que estavam fartas do capitalismo, da globalização e do liberalismo, e que foi estendido pela crítica ao crescimento, soa como uma lanterna em busca desse outro, daquilo que está fora - e o decrescimento se constituiu, como foi apresentado anteriormente, como uma complementação possível deste grito. Mas ao mesmo tempo em que traz à tona a negação, acaba por expulsá-la novamente ao faz explodirem práticas discursivas e ações concretas, tais como as apresentadas anteriormente, que não só postulam qual outro mundo é possível como também constroem uma imagem na qual a noção de relações (ou de nebulosa) preestabelece que todos os possíveis tem um lugar. O outro, portanto, já não está mais “fora”, mas “dentro”. 


\title{
Capítulo 3. Transformações no capitalismo e as contradições da crítica
}

\author{
Redes, rizomas, disseminação, contágio: tudo isso cresce ao acaso \\ $e$ é difícil de conter. Rizomas quebram barreiras, como capim \\ que aflora sob lajes. Esse crescimento tem um motor que foi \\ o crescimento a taxas extraordinárias da capacidade de processar e \\ de transmitir informação. Em outras palavras, um crescimento explosivo da \\ capacidade para conectar coisas e pessoas a custos que tendem a zero. \\ O resultado no horizonte é um imenso coletivo do qual participamos \\ juntos, humanos e não-humanos, organismos e máquinas, idéias e objetos, \\ e cujas conseqüências subversivas de longo prazo são imprevisíveis. \\ O paradoxo é que esse motor de subversão é gerado pelo próprio sistema capitalista, \\ proprietário, individualista e mercantil que ele ameaça subverter.
}

Mauro Almeida

O antropólogo brasileiro Eduardo Viveiros de Castro (2002a, 2002b) propõe o perspectivismo como uma forma de pensar o mundo (analiticamente) e de vivenciá-lo (concretamente). Na cosmologia ameríndia, o perspectivismo corresponde à manutenção e coexistência da diferença. Viveiros de Castro propõe uma teoria-utopia social na qual o "nós” e os “outros” não existam como contradição, mas como um devir. Em sua leitura, a noção de antropofagia na obra do modernista Oswald de Andrade indicava que a síntese não só era indesejada como impossível; a antropofagia fazia render as relações entre as diferenças, canibalizando-as ao invés de destruí-las. O tropicalismo, que colocou em um mesmo palco guitarras elétricas e ritmos populares teria coroado o movimento lançado por Oswald de Andrade e, aos olhos de Viveiros de Castro, indica a melhor maneira de fazer uma crítica social das instituições totalizantes que suprimiriam as diferenças (como o Estado).

Por tudo isso, explica o antropólogo, o “crescimento” e o “desenvolvimento” estão fadados ao fracasso, a não ser que se reconheçam as lógicas sociais que coabitam e povoam o mundo e que os esforços políticos sejam aqueles orientados para estabelecer o trânsito entre elas. Dessa maneira o desenvolvimento poderia fazer algum sentido como a promoção de políticas públicas e sociais que levassem em consideração as diferenças e a necessidade de mediações; já o crescimento não teria como ser levado adiante porque por princípio sua lógica é contrária ao projeto antropofágico.

Viveiros de Castro aponta para uma questão que à primeira vista está distante daquelas postuladas pelo decrescimento, qual seja, a da diversidade sócio-cultural. Na França, apesar 
de os militantes verem com maus olhos as políticas do presidente Nicolas Sarkozy (20072012) com relação às migrações e sempre discutirem o tema, dificilmente incorporam a questão da diferença cultural como um elemento central do decrescimento. Países não europeus ocupam um lugar ambíguo no decrescimento. A América Latica costuma aparecer ora como o locus de alternativa por excelência ${ }^{97}$, ora como totalmente excluída da lógica de crescimento e por isso lhe cabendo a possibilidade de recusá-la (cf. LATOUCHE, 2004). A África Subsaariana, reduzida à imagem da pobreza, geralmente é apresentada como um efeito do crescimento, que expeliu para fora de si a miséria, como condição de sua própria existência ${ }^{98}$. Por fim, há ainda países com grande desigualdade social como Índia e China, que são ora lembrados por suas escolhas político econômicas que privilegiam o crescimento em detrimento a igualdade social, ora por suas tradições culturais e religiosas que podem oferecer elementos para elaborar outras formas de vida ${ }^{99}$.

Por outro lado, o perspectivismo e o decrescimento não estão tão distantes quanto possa parecer. Em nenhum dos casos, a utopia tem uma imagem fixa; ao contrário, a multiplicidade de formas de existência é evocada como o norte da ação política, que se realiza por meio de instrumentos que deem visibilidade às relações entre os fragmentos que comporiam a realidade (assim como a nebulosa do decrescimento é ao mesmo tempo um método de ação e uma forma social almejada, o perspectivismo é uma metodologia e uma utopia). Ambos revelam esforços para elaborar formas de mediação e de comunicação, evitando o problema da comunicação a que os primeiros pós-modernos foram lançados ao postular a fragmentação do mundo e não conseguirem encontrar vias intermediadoras nele/para ele (cf. HARVEY, 2012) ${ }^{100}$.

Neste último capítulo, o objetivo é discutir, por meio da atualização das reivindicações da nova esquerda pelo decrescimento, as contradições dos projetos críticos presentes nesses dois momentos, com especial atenção ao circuito do decrescimento. Para isso, serão

97 Uma mulher viajou de barco a vela ao Brasil para viver em uma pequena cidade no Nordeste do país, onde pretendia ampliar seus conhecimentos sobre o teatro do oprimido, que ela julgava essencial como meio de transformação social porque oferece instrumentos mediadores de conflito.

98 Essa costuma ser a visão do La Décroissance sobre os países da África Subsaariana.

99 Em todas as conferências, desde 2002, sempre há, no mínimo, uma pessoa da Índia para falar sobre o decrescimento e sua realidade local.

100 Não é aleatório que, na busca de maneiras para estabelecer a mediação entre as diferenças, um militante tenha encontrado em Habermas (mais precisamente, em uma apresentação oral na Segunda Conferência Internacional do Decrescimento) uma via interessante de resolução de problemas e conflitos. Já Eduardo Viveiros de Castro propõe justamente uma alternativa à teoria da ação comunicativa. 
levantados alguns elementos que configuram o capitalismo (aquele contra o qual essas mobilizações se colocam), pois assim ficará mais claro o argumento de que os movimentos em questão propõem formas sociais nas quais o negativo (a contra-imagem não determinada do social) perde espaço e, assim, tornam-se contraditórios, não são apenas uma mímese como também não se restringem a ser elementos “externos” que são incorporadas pelo capitalismo. Além disso, este capítulo é uma forma de localizar o contexto geral no qual se insere a emergência das reivindicações sociais que se dizem "novas" e assim abordar, como que de outra perspectiva, a realidade com a qual estas se deparam. Em outras palavras, discutir o capitalismo é discutir o crescimento, o que nos permite levar o decrescimento às últimas consequências e refletir criticamente sobre os rendimentos dos investimentos em outras formas de vida, de consumo, de produção e de relações sociais.

\section{1. O achatamento das contradições}

Ao deparar-se com os problemas semelhantes aos enfrentados por Ellul, Charbonneau, Gorz e Illich, o alemão Herbert Marcuse não abriu mão da obra de Karl Marx para compreender uma realidade social que aparecia como completamente nova e desconhecida, ao mesmo tempo que incorporou elementos da psicanálise freudiana à sua abordagem dialética. Assim como para Ellul, parecia muito importante para Herbert Marcuse a integração total das antigas classes proletárias ao sistema capitalista, fenômeno explicado por ambos em termos de processos subjetivos de alienação. Contudo, Marcuse segue outra direção ao buscar as conexões entre o desenvolvimento do capitalismo e o declínio do potencial revolucionário no Ocidente $^{101}$, enquanto parece haver, nos outros autores, uma démarche que separa de certa forma a "teoria" da "prática".

Isso pode ficar mais claro se pensarmos que Marcuse inverte o problema. Entre os franceses, a ineficácia das lutas sinalizava um descompasso entre o conteúdo e a forma da mobilização. Criticava-se a atuação dos partidos de esquerda porque estes estavam presos a esquemas teóricos ultrapassados pela realidade. Já para Marcuse, a ineficácia das lutas era um elemento constitutivo da sociedade industrial avançada, e não um descompasso. Para os primeiros, o problema seria resolvido uma vez que o conteúdo da mobilização fosse une filosofia, teoria social e política revolucionária. 
esclarecido: compreendida, por exemplo, a "grande metamorfose", seria possível mobilizar forças contra os novos mecanismos de dominação e exploração. Marcuse, por sua vez, propunha-se a compreender a ineficácia das lutas e da crítica em sua relação com o capitalismo contemporâneo. Seu ponto de partida é: o que faz com que a crítica social tenha se enfraquecido a ponto de não ter mais nenhum efeito sobre o todo? Entre os demais, a questão da transformação social parece ser o ponto de chegada: tendo feito um diagnóstico do nosso tempo, o que podemos fazer para transformá-lo? Marcuse não separava, portanto, teoria de um lado e prática de outro, mas buscava compreender a imbricação dialética entre elas. Dessa maneira, recusou-se tratar o problema como falta de informação por parte das pessoas, que uma vez esclarecidas poderiam se revoltar contra o sistema.

Para isso, Marcuse chama a atenção para a relação entre ideologia e condições materiais, tratando-a dialeticamente. Isso significa que a ideologia não era um elemento "a mais" em sua análise, e sim algo central para compreender o que se passa com essa suposta nova forma social. Isso o diferencia de Ellul, Illich, Charbonneau e mesmo Gorz, que desenvolviam algo como uma análise de camadas, como se a técnica fosse o centro de "contaminação" de outras dimensões da vida (gradativamente ou não). O efeito desse tipo de análise foi a impossibilidade de responder satisfatoriamente a questões como a desigualdade socioeconômica ou a já mencionada passagem da teoria à ação.

Ao mobilizar o conceito de ideologia, Marcuse não caiu na simplificada visão de uma superestrutura que reflete a estrutura. Sua contribuição consiste em observar como a ideologia se articula com a sociedade estabelecida, dando atenção a questões que estavam fora do horizonte de seus contemporâneos.

Marcuse deparou-se com os "avanços" dos mecanismos sociais que, ao tornarem a vida mais fácil, expandem cada vez mais a destruição do livre desenvolvimento das necessidades e faculdades humanas; mantêm-se pela constante ameaça de guerra e dependem da repressão das possibilidades reais de amenizar a luta pela existência. O ponto central de Marcuse, considerando seu projeto teórico-político, é compreender como esse mundo, no qual os avanços são também destruição, inviabilizou o surgimento de uma oposição eficaz.

Primeiramente, a contradição que Marcuse identifica entre avanço e retrocesso distancia-se metodologicamente da compreensão desenvolvida por André Gorz e Ivan Illich, embora sejam de fato muito próximas. Marcuse não concebe a relação entre progresso e 
barbárie como uma sequência temporal. Eficiência técnica e dominação social sempre já existiram como contraditórias na sociedade industrial avançada. Pode-se dizer que, diferente dos outros autores que viam naquele momento uma novidade completa, Marcuse estava escrevendo sobre o desenvolvimento histórico das contradições do capitalismo. Nessa nova fase, segundo ele, a dominação do homem pelo homem continua a existir, mas agora não sob a forma de dependência pessoal, mas sim de dependência à "ordem objetiva", ou seja, às leis da economia, do mercado. Nessa nova forma de dependência, a produtividade é o que mobiliza a totalidade social em detrimento de interesses individuais e grupais. Essa forma se mantém porque implica uma racionalidade inédita: apesar da escravização progressiva do homem por um aparato produtor que perpetua a luta pela existência, a estrutura hierárquica se mantém, enquanto a sociedade explora com eficiência os recursos naturais e mentais e distribui os benefícios dessa exploração para setores cada vez mais amplos.

A perda da dimensão crítica e da capacidade de oposição ao todo é a contrapartida ideológica do "processo material no qual a sociedade industrial desenvolvida silencia e reconcilia a oposição" (MARCUSE, 1969, p. 31). Mas a contrapartida não significa uma esfera separada, como se a produção ideológica fosse "contaminada" pela contradição entre eficiência tecnológica e dominação social. É como se a ideologia tivesse sido engolfada pela realidade, e agora há uma identidade entre o sujeito e a exigência que lhe é imposta. Agora "a ideologia está no próprio processo de produção" (Ibid: 32).

Entre os diversos temas trabalhados por Marcuse em $O$ Homem Unidimensional, a questão do unidimensionamento das classes e o achatamento da subjetividade dialogam diretamente (embora não propositadamente) com os autores da ecologia política. Todos dizem que estamos diante de uma sociedade na qual não há mais contradição de classes (ao menos aparentemente), que o trabalho foi humanizado e que todos podem usufruir dos mesmos bens e serviços, inclusive lazeres. Assim, quando Marcuse utiliza o termo "unidimensional", está chamando a atenção para o fenômeno dessa aparência de ausência de contradições que, ao mesmo tempo, deixa de ser aparência e torna-se realidade, afinal, a sociedade agora funciona de fato como se todos partilhassem dos mesmos interesses.

O suposto desaparecimento da sociedade de classes é uma das facetas da aparente coesão. As razões para as muitas "constatações" da supressão da desigualdade de classes são de duas ordens. Por um lado, há toda uma mobilização social contra "ameaças" externas, 
sobretudo o comunismo, fazendo com que, aparentemente, "todos" estejam do mesmo lado contra um inimigo externo comum. Por outro lado, cada vez mais pessoas são atraídas pelo processo de realização do capital, provocando uma mudança na composição da classe trabalhadora, não apenas quantitativas (profissões que antes não faziam parte do setor produtivo passam a ser produtivas), mas também qualitativas: ampliou-se o universo da exploração, de modo que ele passou a funcionar como uma totalidade em que os indivíduos atomizados servem o sistema tanto em seu trabalho como em seu lazer.

A contraparte subjetiva desse processo é a sensação de que há menos sofrimento e menos exploração do que antes. A elevação dos padrões de vida, a mecanização completa do trabalho que substituiu a fadiga muscular por uma fadiga mental, a estratificação ocupacional que explode as identidades de classe, e por fim a tecnologia que transforma dominação em administração, tudo isso faz com que a servidão torne-se de certa forma aceitável. Em suma, a decomposição do indivíduo é "aliviada" pela riqueza com a qual ele se beneficia e pela transformação das atividades produtivas.

É importante ressaltar que Marcuse estava se referindo a uma classe média geral, resultante do Estado de Bem Estar, e que na França, essa mesma classe média era não só problematizada mas era o setor do qual emergiam as novas formas de militância e de ação política (como os protestos de bicicleta e os cientistas engajados). Isso significa que tal análise da substituição do sofrimento físico pelo sofrimento mental precisaria de mediações para ser estendida a países ou regiões pobres em que se verifica a falta de condições objetivas para a efetivação dessa substituição. Atualmente, este é um problema que se coloca para os militantes do decrescimento que, também oriundos das classes médias, dificilmente conseguem estender a proposta de decrescer a economia para países como o Brasil ${ }^{102}$.

A participação maior da população na produção de riquezas é, diz Marcuse, uma condição da sustentação do modo de produção capitalista. Para que esse aumento de riquezas não se converta em um potencial libertador (Marx preconizava como requisito da revolução

102 Para Latouche (2004), os países do Sul ainda podem se "des-desenvolver", ou seja, sair do projeto de desenvolvimento, como se não houvesse nenhuma relação que ligasse de maneira profunda os países desenvolvidos e os subdesenvolvidos. Tudo se passa como se fosse mera questão de escolha dos países subdesenvolvidos de adotarem um "princípio” de crescimento. John Bellamy Foster (2011) faz duras críticas ao decrescimento, sendo uma delas a questão da fragilidade da proposta do decrescimento frente a realidades de países do Sul. Em suma, uma vez que o decrescimento não associa crescimento a capitalismo, só consegue ler a solução da pobreza como um desvencilhamento da cultura desenvolvimentista dos países do norte. 
social um nível de produção material que pudesse libertar as pessoas de suas necessidades ${ }^{103}$ ), ele é controlado, guiado, pois o que se consome não são tanto as propriedades intrínsecas ao produto (seu valor de uso), mas os valores e promessas do sistema. "Por trás do véu tecnológico, por trás do véu político de democracia, surge a realidade, a servidão universal, a perda de dignidade humana em uma liberdade de escolha prefabricada" (MARCUSE, 1969, p. $23)^{104}$.

Sociedade do consumo não é, consequentemente, aquela em que as pessoas consomem mais produtos, mas uma sociedade que funciona unificando classes em contradição através do "aumento da massa de bens e serviços supérfluos e suntuários que estão além da satisfação de necessidades materiais vitais" (Ibid: 27). Por outro lado, para dar conta do aumento de produtos supérfluos, é preciso aumentar a população consumidora. Essa é a nova forma de produção da mais valia: intensificação do trabalho somada a investimentos em serviços supérfluos e lucrativos. Por essa razão Marcuse defende enfaticamente que "sociedade do consumo" é uma denominação imprópria, afinal, são os interesses (produção de mais-valia) que controlam a produção que organizam a sociedade.

Deparamo-nos, mais uma vez, com um ponto em que Marcuse se aproxima de seus contemporâneos, mas logo percebemos em que medida sua crítica perfaz um caminho bastante distinto. Naquele momento, a preocupação com o consumo parecia ser secundária, pois representava uma "dimensão" que era atingida pela lógica da técnica totalizante. Marcuse procura mostrar que o consumo assume uma nova configuração, a qual permite ao capitalismo manter seu funcionamento apesar de provocar servidão e exploração. Afinal, não se trata apenas de consumir mais, em maior quantidade, mas do fato de o consumo ter se convertido em uma dimensão ideológica por excelência.

Os produtos doutrinam e manipulam; promovem uma falsa consciência que é imune à sua falsidade. E, ao ficarem esses produtos benéficos à disposição de maior número de indivíduos e de classes sociais, a doutrinação que eles portam deixa de ser publicidade; torna-se um estilo de vida. [...] Surge assim um padrão de pensamento e comportamento unidimensionais no qual as

103 Pode-se também apontar outra contradição do consumo que tange a questão da novidade: o controle do consumo tal como apontado por Marcuse seria uma maneira de controlar a ânsia por novas condições sociais, e assim encarcerar o novo em uma lógica de insatisfação perpétua. Se a publicidade, como dizem os militantes do decrescimento, é responsável por criar novas necessidades, a impossibilidade de satisfazê-las é o outro lado desse processo.

$104 \mathrm{O}$ modo como Marcuse formula a questão da perda da liberdade é bastante próxima de uma série de questionamentos acionados no interior da nova esquerda e que se dizem afeitas à problemática libertária, como foi visto anteriormente. 
ideias, as aspirações e os objetivos que por seu conteúdo transcendem o universo estabelecido da palavra e da ação são repelidos ou reduzidos a termos desse universo.

MARCUSE, 1969, p. 32 - grifos do autor

$\mathrm{O}$ aplainamento das necessidades humanas, que foi muitas vezes considerado como produto da dissolução das classes, foi resultado não só das transformações políticas e no mundo do trabalho, mas também da massificação da cultura. É importante ressaltar que essa dimensão não é mais um "caso", mas é central no unidimensionamento da sociedade.

Historicamente, houve um período em que a cultura superior ocupava um lugar de alienação artística, escrevia Marcuse, e com isso protegia a contradição ("as possibilidades derrotadas, as esperanças não concretizadas e as promessas traídas”). As contradições do capital não desaparecem de fato mas passam a aparecer como se tivessem se conciliado, de modo que continuam a se reproduzir sem fazer explodir o sistema social. Como diz Marcuse, a assimilação estabelece uma igualdade cultural sem acabar com a dominação. Uma vez que a cultura superior se torna parte da cultura material, deixa de existir um espaço de negação e de contradição. Os antigos heróis, por exemplo, eram imagens de outro estilo de vida; na sociedade reconciliada, esses personagens são "aberrações ou tipos da mesma vida, servindo mais como afirmações do que como negação da ordem estabelecida" (MARCUSE, 1969, p. $71)$.

O desaparecimento, ou melhor, a reconciliação que se dá com as antigas contradições entre a produção artística e as relações sociais é a contrapartida da transformação da alienação artística em mercadoria, por meio da submissão da arte ao processo de racionalidade tecnológica através dos meios de comunicação, afinal são eles os responsáveis por produzir e distribuir em escala cada vez maior a cultura. A massificação não trouxe a arte como era para toda a sociedade, e sim a transformou: os clássicos voltam, mas diferentes de si mesmos pois privados de sua força antagônica e "do alheamento que foi a própria dimensão de sua verdade". Em suma, a igualdade cultural que se produz pelos meios de comunicação de massa não acaba com a dominação ${ }^{105}$.

Além de aniquilar a transcendência no domínio da arte, da política e do trabalho, a sociedade unidimensional o fez esfera instintiva. A ausência ou desaparecimento da negação

105 Adiante, veremos como esse argumento é retomado por autores contemporâneos para pensar o capitalismo financeiro e a pós-modernidade, como Fredric Jameson e David Harvey. 
no seio da sociedade unidimensional explica-se também (e, sobretudo) pela psicanálise. As transformações no cotidiano do trabalho fazem parecer que o sofrimento tornou-se menor e as políticas do Estado de Bem Estar social tiveram um efeito similar: o poder que a sociedade exerce sobre o homem é absolvido pela eficácia e pela produtividade e o "bem-estar" impera de modo que parece não haver justificativas para opor-se ao sistema. "O resultado é a atrofia dos órgãos mentais, impedindo-os de perceber as contradições e alternativas e, na única dimensão restante da racionalidade tecnológica, prevalece a Consciência Feliz" (MARCUSE, 1969, p. 88)

Embora as contradições tenham se mantido em pleno funcionamento, há um amplo apoio das pessoas, inclusive do proletariado, às relações de produção capitalista, já que tudo se passa como se não houvesse mais contradições. "Desde que correspondem à realidade em questão, o pensamento e o comportamento expressam uma falsa consciência, reagindo à preservação de uma falsa ordem dos fatos e contribuindo para ela" (MARCUSE, 1969, p. 143). Longe de ser neutro, o progresso é um caminho que leva a uma "pacificação da existência": reduzindo cada vez mais o tempo de trabalho necessário, o desenvolvimento tecnológico organiza as necessidades e desejos, enquanto a ciência e a tecnologia, que acarretam na produtividade crescente, desafiam a transcendência.

O método dialético conduz a argumentação de Marcuse. Ao mesmo tempo, ele se questiona sobre sua validade na sociedade unidimensional, afinal não parece mais suficiente pensar em termos de uma negação do todo no interior do todo, pois está em curso uma suspensão das forças negativas e destruidoras. O arranjo entre a filosofia, a ciência e o universo da locução de um lado e as relações sociais de outro levou à supressão do negativo, da possibilidade de transcendência. As contradições são tratadas como lados opostos reconciliados, de modo que não mais carregam uma potência transformadora e como se não houvesse mais espaço para a recusa.

O que vemos no período atual parece representar algo como uma imobilização da dialética da negatividade. [...] Formulando a questão de modo mais geral: parece-me que a principal dificuldade reside no conceito dialético segundo o qual as forças negativas se desenvolvem no seio de um sistema antagônico existente. Parece que esse desenvolvimento da negatividade no interior do todo antagônico é, hoje, dificilmente demonstrável.

(MARCUSE, 1972, p. 160) 
Tudo se passa como se não houvesse mais espaço para a recusa. Além de buscar compreender de que modo o progresso técnico e o crescimento da riqueza social eram acompanhados pela servidão ampliada, Marcuse (1973) pretendia entender por que motivos essa contradição não era alvo de críticas e por que a esquerda parecia não conseguir organizar uma oposição real a esse mundo de contradições.

A resposta a essa questão está na ideologia. A racionalidade levou ao aumento da produtividade e do padrão de vida, mas "produziu um padrão de mente e comportamento que justificou e absolveu até mesmo as particularidades mais destrutivas e opressivas do empreendimento" (MARCUSE, 1969, p. 144). A absolvição da destruição, da servidão, da exploração e da opressão se dá pela ideologia. Na sociedade unidimensional, tudo isso é concebido como o preço do progresso, assim como a renúncia e o trabalho são lidos como o preço da satisfação e do prazer. As alternativas aparecem como utópicas.

Isso não significa, no entanto, que Marcuse acredite na aniquilação definitiva da potência da negação. É fato que ele não estava engajado em inventariar ações e mobilizações como exemplos de crítica potencialmente transformadora - embora militasse em favor de alguns movimentos e apoiasse a auto-gestão (MARCUSE, 2007) - mas sua motivação central era a transformação radical da sociedade. A grande recusa sobre a qual Marcuse fala só pode ser realizada por indivíduos conscientes, para os quais as irracionalidades deixem de aparecer como racionalidade.

Se fosse possível transcrever a argumentação de Marcuse sobre a reconfiguração do capitalismo contemporâneo em termos muito gerais, a sociedade unidimensional corresponde a uma formação social, econômica e cultural na qual nenhuma dessas esferas está em contradição com as demais. Mas não apenas não se identifica mais um “fora” como o próprio “fora” foi incorporado e por isso hoje se diz que a crítica é o motor do capitalismo. O que Marcuse apontava era que o capitalismo não se reformulava apenas incorporando as críticas que eram dirigidas a partir de um espaço outro, mas que deu espaço, em seu interior, para aquilo que lhe parecia exterior e potencialmente destrutivo.

É importante ressaltar que Marcuse não conclui pela superioridade moral de períodos precedentes, nos quais o homem e a sociedade eram marcados por relações de oposição; na verdade, trata-se de mostrar que há um desdobramento de um momento para o outro no qual 
instauram-se novas relações que, ao mesmo tempo, já estavam postas, ao mesmo tempo que estas não superam o passado - a verdadeira superação seria “catastrófica”, reverteria a sociedade estabelecida, defendia Marcuse.

As transformações que Charbonneau, Ellul, Illich, Gorz e Marcuse vivenciavam nos anos 1960 foi muitas vezes concebida como uma transformação do capitalismo em outra coisa - que não necessariamente teria se tornado melhor ou mais aceitável. A financeirização do capital que teve início dos anos 1980 foi lida, com frequência, da mesma maneira, como uma ruptura radical com o momento histórico precedente.

De forma análoga, vimos como o decrescimento aciona, em alguma medida, o discurso da novidade como se as estratégias de ação e as questões mobilizadas fossem completamente desconectadas de períodos históricos precedentes, e, mais do que isso, como se a novidade viesse também de sua desconexão completa frente ao mundo no qual se insere (criando métodos de ação e formas de vida alternativas). Em outras palavras, o discurso da novidade implica uma desconexão temporal e contextual do decrescimento que corresponde às visões que concebem as transformações históricas como rupturas radicais da economia.

Para compreender em que medida o decrescimento não é uma forma completamente nova de se fazer política e como esse argumento da novidade apaga certas conexões, fizemos uma exposição da nova esquerda no primeiro capítulo e em seguida levantamos as formas de concretização da crítica ao crescimento econômico, indicando que os pontos de convergência dizem respeito à formulação de uma nova compreensão do social. Agora, trata-se de localizar a relação do decrescimento com seu contexto econômico, social e político. Por meio de um mapeamento do debate sobre o capitalismo contemporâneo e o pós-modernismo, poderemos perceber em que medida há uma relação entre as transformações instauradas nos anos 1970 e o capitalismo industrial, assim como o pós-modernismo é um desdobramento de certas facetas do modernismo; e mais do que isso, que ambos estão profundamente relacionados. A partir dessa discussão, torna-se possível estender a relação entre as questões do decrescimento e da nova esquerda para apontar possíveis relações entre as alternativas e o mundo que pretendem criticar. Em suma, seria passar de uma continuidade “interna” (da nova esquerda para o decrescimento) para uma continuidade “externa” (o decrescimento e a nova esquerda frente ao mundo que as cerca), sem perder de vista que tais continuidades só podem se configurar a partir de uma série de transformações. 


\section{2. Economia de espelhos e pós-modernismo}

Luc Boltanski e Ève Chiapello (2009) voltam para os agitados anos 1960 na França para sugerir que as críticas formuladas naquele momento teriam germinado as bases de um “novo espírito do capitalismo”. Por meio da análise da reconfiguração do mundo do trabalho (inclusive os discursos ali proferidos), os autores discutem a questão da manutenção do capitalismo, que apesar de ser um sistema absurdo, não só continua a existir como é apoiado e defendido pelas pessoas que dele são vítimas (embora não seja o foco do livro mostrar em que consiste a exploração). Como o capitalismo é um sistema (o único, dizem) que se justifica por si mesmo, precisa buscar suas justificativas em outra instância que não ele próprio, e assim torna-se importante estudar seu “espírito”.

Ideologia seria um conjunto de crenças compartilhadas, inscritas nas instituições e ancoradas na realidade que emergem para justificar o absurdo sistema capitalista. Mas melhor do que ideologia, que seria, segundo Boltanski e Chiapello, carregado de um sentido de mistificação da realidade, seria a noção de espírito do capitalismo. O novo espírito reconfigura o conjunto de preceitos morais e éticos, as justificativas individuais e sociais que garantem uma participação engajada das pessoas no sistema uma vez que as mobilizações críticas de Maio de 68 colocaram em xeque o espírito precedente. É como se o espírito do capitalismo tivesse uma "função" determinada, mas ao mesmo tempo fosse o lugar de onde podem aparecer as críticas que colocam em xeque o capitalismo. Menos do que uma mentira, ou um subterfúgio acionado pelas classes dominantes para garantir o consentimento dos dominados, a ideologia é, na leitura dos autores, o esquema em que todos se apoiam, as crenças, as representações e os sentidos que o capitalismo domesticou para garantir sua sobrevivência e sua ampliação.

Ao se debruçarem sobre essa questão, os autores trazem uma grande contribuição ao mostrar que o novo espírito do capitalismo aproxima a vida subjetiva e os desejos ao funcionamento da economia, não apenas do ponto de vista do trabalho, mas de toda a organização: na produção, a circulação, no consumo, nos meios de comunicação. Propostas de novas formas de organização flexível tentavam incorporar a problematização da hierarquia: redes de empresas que funcionam por colaborações temporárias. As exigências de autonomia, criatividade, autenticidade e libertação, as críticas ao poder hierarquizado, ao paternalismo e 
autoritarismo, à imposição de horários, tarefas, comportamentos aparecem também no interior das empresas, por meio dos projetos: “ninguém mais está limitado pela seção a qual pertence nem totalmente submetido à autoridade de um chefe, pois todas as fronteiras poem ser transpostas pela virtude dos projetos” (BOLTANSKI; CHIAPELLO, 2009, p. 122). Engajar-se em projetos para conseguir estabelecer redes e abrir portas para novos projetos aparece como uma "aventura pessoalmente estimulante". Os atrativos do novo espírito não dizem respeito à estabilidade que se alcançará, mas à liberdade que as empresas e os trabalhos oferecem. No regime de trabalho por projetos, não há mais patrões e empregados, mas colaboradores, a autogestão e apagam-se as fronteiras entre trabalho e lazer.

Na década de 1960, o alvo da literatura de gestão empresarial eram os altos executivos, como se bastasse a adesão deste setor social para a manutenção do sistema. Nos anos 1990, houve um espraiamento dessa preocupação juntamente com uma alteração no próprio discurso mobilizador. "Empresas enxutas” que operam "em rede”, com uma “multidão de participantes” que trabalham "em equipe” ou por "projetos”, orientadas para a "satisfação do cliente" requerem uma massa de trabalhadores flexível, que possam ser contratados ou demitidos quando melhor convier à produção de capital. A motivação se dá por meio da organização dos trabalhadores em pequenas equipes pluridisciplinares supostamente autogeridas, de modo que não há mais um chefe a quem se deve obedecer. Tudo se passa como se cada trabalhador fosse um ponto de uma rede, e como se os conflitos no interior das relações de trabalho decorresse de outros fatores que não da desigualdade de classes.

Sem um controle centralizado, são as pessoas que controlam a si mesmas e a própria motivação não deve vir de fora. A adesão ao sistema não se dê mais pela força, mas de forma voluntária, concluem os autores. O resultado é que a coerção externa dos dispositivos organizacionais parece desaparecer mas, na verdade, reaparece na dimensão subjetiva quando cada indivíduo deve internalizar o controle.

Isso explica a importância atribuída a noções como 'envolvimento pessoal' ou de 'motivações intrínsecas', que são motivações ligadas ao desejo e ao prazer de realizar o trabalho, e não a um sistema qualquer de puniçõesrecompensas impingido de fora para dentro, só capaz de gerar 'motivações extrínsecas'.

BOLTANSKI; CHIAPELLO, 2009, p. 110

Nos anos 1960, o estímulo ao progresso econômico e social, a garantia de carreiras e 
de trabalho por parte do Estado-providência asseguravam a legitimidade do sistema. Nos anos 1990, a mudança, o risco e a mobilidade substituíram a ideia de garantia e os atrativos mudam de aspecto. Fala-se em liberdade (tudo é possível, a criatividade é o motor do trabalho, as descobertas são permanentes) e desenvolvimento pessoal (agora são valorizadas capacidades humanas que antes não importavam, como se o trabalho favorece o desenvolvimento livre de capacidades).

Ainda na leitura de Boltanski e Chiapello, a incorporação da crítica não provoca apenas mudanças na ideologia e nas relações de trabalho. A própria lógica de produção e acumulação como um todo se transformou para se adequar aos questionamentos das relações sociais existentes. O registro da propriedade se altera e a poupança, que deve ser economizada, guardada e restrita a seu proprietário é substituída pela “disponibilidade”, ou seja, um propriedade plena mas temporária, que é móvel e pode ser substituída quando for necessário. Passa a ser mais racional o acesso fácil e temporário a recursos emprestados ou alugados, que são utilizados apenas no contexto de um projeto, do que a posse de grandes prédios, do emprego de trabalhadores diretos, etc - donde as terceirizações, a importância das comunicações e o papel preponderante da informação nessa nova economia.

A exploração (e é essa a definição de capitalismo) se mantém, por novos argumentos e por novos meios: a mobilidade, que é exaltada no mundo conexionista, só se realiza mediante a exploração de setores sociais que não são móveis. Os fracos são aqueles que constroem as condições dessa mobilidade:

O grande estabelece um elo a distância. Conecta-se com uma pessoa (que pode estar no centro de um grupo) e escolhe ou põe, nesse lugar, alguém que mantém esse elo. O dublê precisa ficar no lugar onde foi posto. Sua permanência nesse nó da rede permite que o grande se desloque.

BOLTANSKI; CHIAPELLO, 2009, p. 372

A desigualdade social não é vista, entretanto, como um resultado dessa exploração. A nova moral cotidiana implicada no novo espírito do capitalismo faz com que os problemas sociais que insistem em aparecer sejam tratados no registro das redes. Nos anos 1980, quando a miséria se mostrava cada vez mais alarmante e sem perspectivas de solução fácil, a “exclusão” surgia como noção explicativa. A noção de exploração é substituída pela de corte das relações, ou seja, estar excluído é estar cortado de qualquer conexão, é ser cortado das redes. 
As teorias das redes, juntamente com o mundo conexionista, parecem ter colocado lado a lado patrões, empregados, trabalho e lazer, nós e os outros, natureza e cultura. Os problemas sociais que insistem em aparecer, como a miséria, são por sua vez tratados como um rompimento com as relações. Os (novamente) novos movimentos sociais que tomaram forma na década de 1980 e início de 1990 "politizaram a exclusão" (BOLTANSKI; CHIAPELLO, 2009, p. 358), articulando a ajuda humanitária de um lado e a transgressão dos anos 1960 e 70 de outro. Isso significa que os próprios movimentos adotaram a forma conexionista ao substituírem a afiliação pela ação comum e circunstancial.

Paralelamente aos movimentos sociais, uma série de dispositivos foi elaborada com vistas a reintegrar os excluídos ou para oferecer condições de mobilidade (exigência para a existência social em um mundo que funciona em rede) e frear a exclusão, sendo estes dispositivos também em forma de rede. Com o objetivo de restituir laços, há uma infinidade de projetos voltados para desenvolver uma empregabilidade mínima que permita aos atendidos ao menos entrarem nas relações, e então tem-se “a ideia de que, em termos de integração, a participação em qualquer atividade constituída na forma de um projeto definido (fosse ele qual fosse - cultural, esportivo, social) é preferível à ausência de atividade” (BOLTANSKI; CHIAPELLO, 2009, p. 406).

O mapeamento acurado dos autores apresenta as continuidades entre crítica e reformulação do capitalismo mas ao mesmo tempo recusa o caminho inverso, de modo que o efeito dessa análise é uma formulação de um novo espírito do capitalismo que não tem qualquer conexão mais profunda com o período histórico precedente. A tese da descontinuidade no desenvolvimento do capitalismo decorre não apenas da separação entre economia e política, mas da ausência de uma reflexão mais aprofundada sobre o que viria a ser o capitalismo. Afinal, se o espírito do capitalismo é novo, o capitalismo ele mesmo é velho, mas pouca coisa é dita sobre tal relação.

Ao separarem o "espírito” do capitalismo de seu funcionamento econômico, os autores recaem em uma explicação da transformação do capitalismo que confere atenção primordial ao componente político de uma sociedade, correndo o sério risco de ignorar relações de outra ordem que podem ter contribuído para sua manutenção enquanto se transforma. Em outras palavras, a ênfase que Boltanski e Chiapello dão às justificativas e à ideologia do capitalismo contemporâneo expressa a preeminência destas sobre a transformação das relações sociais em 
geral (e econômicas em particular). Afirmam que o espírito é aquilo que faz o capitalismo garantir sua sobrevivência, mas não explicam o que vem a ser esse capitalismo. É como se as transformações do capitalismo (e o que seria isso?) decorresse sobretudo da necessidade de responder às críticas que lhe são feitas: “o principal operador de criação e transformação do espírito do capitalismo é a crítica”, definem sistematicamente os autores (p. 486).

Essas críticas, por sua vez, decorrem do fato de sempre restar, entre as pessoas, espaços não colonizados pelo processo de acumulação e assim conseguirem estranhar em alguma medida o sistema ao qual são submetidas (BOLTANSKI; CHIAPELLO, 2009, p. 483). Logo, é como se a transformação do capitalismo fosse indeterminada, ou que toda mudança fosse exclusivamente decorrente de algo externo, oriundo de uma tomada de consciência. Consequentemente, não existiria nenhuma razão interna ao próprio capitalismo no engendramento de sua crise e nenhuma continuidade entre momentos históricos distintos ${ }^{106}$.

O problema na análise de Boltanski e Chiapello, portanto, não reside nas aproximações que tão bem estabelecem entre a crítica e a forma de existência do capitalismo, mas no modo como tais aproximações são tratadas. Jogam luz sobre as transformações históricas para, em seguida, convertê-las em lei de funcionamento do capitalismo. Logo, mais interessante do que a démarche teórica dos autores são os argumentos (aqui levantados) que dão sustentação à defesa de um novo espírito: o modo como mostram as novidades do capitalismo em sua interversão da crítica por meio de um colamento entre mecanismos de reprodução material, crítica social e desejos subjetivos.

Por mais que se possam fazer críticas à metodologia adotada por Boltanski e Chiapello, é preciso levar em consideração que suas contribuições são bastante significativas no que diz respeito ao procedimento de tecer relações entre esferas aparentemente desconectadas da vida social e mostrar que há nessas relações uma inovação do capitalismo. David Harvey e Fredric Jameson parecem dar um passo adiante uma vez que oferecem uma outra abordagem que não parte do poder transformador da crítica, mas sim do ponto de chegada de Boltanski e Chiapello que é a transformação da crítica em motor do capitalismo.

106 A questão da crise no interior do próprio sistema capitalista será abordada adiante. Neste momento, ela é enunciada apenas como forma de elucidar um problema que Boltanski e Chiapello deixam de fora considerações sobre o que vem a ser o capitalismo ao não levarem em conta que a economia pode gerar seu próprio “limite”, ou que a própria lógica da acumulação capitalista pode culminar em sua negação. 
Segundo David Harvey (2012) entre 1965 e 1973, o fordismo e o keynesianismo não conseguiam conter as contradições do capitalismo. A legitimidade do sistema, que fora garantida pela manutenção dos compromissos do Estado com os trabalhadores (que, apesar do debate sobre sua desaparição, continuava existindo), ruiu com a crise econômica. Os gastos públicos enrijeciam a possibilidade de expandir a base fiscal do capital e a forma encontrada pelo governo norte-americano para flexibilizá-lo foi a impressão de moeda. O resultado foi uma onda inflacionária que gerou efeitos na economia internacional. A crise do petróleo em 1973 deu um golpe final no modelo político-econômico que levara ao crescimento econômico nos países de capitalismo avançado no pós-guerra. O desdobramento foi um remodelamento das experiências nos domínios da organização econômica e da vida social e política que Harvey denomina acumulação flexível.

Fredric Jameson (2001) volta a Karl Marx para explicar tanto as fontes quanto os efeitos dessa mudança. A queda tendencial da taxa de lucro (apresentada anteriormente) não conseguiu ser resolvida pela busca de novos mercados, que estão saturados, e a forma encontrada foi fazer o capital circular por meio de transações financeiras: “o próprio capital começa a ter flutuação livre. Ele se separa do 'contexto concreto' de sua geografia produtiva. O dinheiro se torna, em um segundo sentido e em um segundo grau, abstrato (sempre foi abstrato no sentido primeiro e básico)”107.

Decerto, continua Jameson, o capital sempre buscou novos espaços para se reproduzir, mas agora começa a viver nas bolsas de valores, quando o valor se torna espectro, “competindo entre si e uma fantasmagoria mundial desencarnada” (JAMESON, 2001, p. 151): uma economia que opera descolada das relações sociais de produção ${ }^{108}$ e que, por meio dessa abstração, procede como se o capitalismo fosse suficiente em si mesmo, prescindindo de novos espaços exteriores para explorar.

O fenômeno expresso pelo descolamento é analisado por Harvey como uma economia

107 O segundo grau a que Jameson se refere é tratado por Marx como “fetiche do capital”, que é um desdobramento do fetiche do dinheiro. Vale lembrar que o fetiche do capital não é uma fase mais avançada, e sim mais abstrata. Essa abstração é efeito de um desdobramento dialético, ou seja, a forma do capital financeiro (D-D') já estava contida na forma mais “simples” da relação D-M-D', que por sua vez, é uma inversão da relação M-D-M.

108 Isso não significa que tais relações tenham deixado de existir, mas sim que o capitalismo entrou em uma fase de acumulação desterritorializada, na qual a multiplicação do capital se dá sobretudo por meio da especulação financeira. 
de espelhos. Essa nova forma econômica caracteriza-se pela flexibilização dos processos de trabalho, dos mercados de trabalho, dos produtos e dos padrões de consumo, bem como pela emergência de novos setores da produção, novos mercados, pela ênfase na inovação e pela reconfiguração das relações temporais e geográficas. Os lucros aumentaram sobretudo em decorrência da desregulamentação dos mercados financeiros, sendo que se tornou mais rentável aplicar no mercado financeiro do que na indústria.

Com relação ao trabalho, houve uma reorganização correspondente à reconstrução de focos de acumulação em locais que não tinham tradição industrial, de um lado, e de outro à importação de práticas realizadas nestas regiões para o centro. Regimes e contratos de trabalho se tornaram flexíveis, tanto do ponto de vista numérico quanto funcional: cada empresa contrata agora serviços de acordo com suas necessidades, gerando um quadro fragmentado e móvel, muitas vezes eliminando direitos trabalhistas em favor da flexibilização da mão de obra. Setores sociais marginalizados, como mulheres, negros e minorias étnicas foram incorporados ao mercado de trabalho mas apenas de modo que acentuou a vulnerabilidade de muitos desses grupos.

A organização industrial também passou por transformações. A subcontratação deu espaço para a emergência de pequenos negócios que funcionam de forma doméstica (por oposição à racionalização de grandes empresas). O imperativo de flexibilidade tornou as grandes corporações pesadas demais e muitas faliram enquanto a formação de novos negócios disparou (entre 1975 e 1981, o número de novos empreendimentos duplicou nos Estados Unidos). Ao mesmo tempo, a capacidade de dispersão geográfica da produção em pequena escala não levou à diminuição do poder corporativo, pois as corporações bem organizadas conseguem manter vantagens comparativas sobre pequenos e novos empreendimentos mesmo diante da necessidade de reformulações.

Do lado do consumo, a flexibilidade também tornou-se palavra de ordem. A produção em massa foi substituída pela variedade de bens produzidos a preços baixos e em pequenos lotes. Assim, foi possível atender a novas necessidades do mercado que passaram a variar com cada vez maior velocidade. Como diz Harvey (2012, p. 148):

A acumulação flexível foi acompanhada na ponta do consumo, portanto, por uma atenção muito maior às modas fugazes e pela mobilização de todos os artifícios de indução de necessidades e de transformação cultural que isso implica. A estética relativamente estável do modernismo fordista cedeu lugar a todo o fermento, instabilidade e qualidade fugidias de uma estética pós- 
moderna que celebra a diferença, a efemeridade, o espetáculo, a moda e a mercadificação de formas culturais.

Todas essas mudanças acompanharam a reorganização do sistema financeiro global, que também foi marcado por um movimento dual: assim como grandes empresas se fortaleceram paralelamente à proliferação de pequenos empreendimentos, formaram-se conglomerados de poder global enquanto atividades e fluxos financeiros se multiplicaram e descentralizaram. Tratava-se de um processo de unificação do mercado financeiro em nível global que passava pela mobilidade geográfica e pela desterritorialização do capital, bem como pela mobilidade e fluidez nos investimentos, pela "capacidade de dirigir os fluxos de capital para lá e para cá de maneiras que quase parecem desprezar as restrições de tempo e de espaço que costumam ter efeito sobre as atividades materiais de produção e consumo" (HARVEY, 2012, p. 155).

Nesta nova configuração, não há mais uma contradição entre monopólio e competição entre grandes empresas e pequenos produtores, ou entre os grandes conglomerados financeiros e os fluxos dispersos e as atividades descentralizadas. O que Harvey procura mostrar é que a flexibilidade de capitais não provocou desordem e desorganização; ao contrário, afirma o autor, o capitalismo se organiza através da dispersão, da mobilidade geográfica e da flexibilidade em todos os níveis (produção, consumo, distribuição, cultura, necessidades, gostos). Trata-se de uma economia de espelhos porque seu modo de funcionar faz parecer que o capital não depende de mais nada a não ser ele mesmo para existir, se reproduzir e crescer.

E isso se desdobra em outras dimensões da economia para além da esfera financeira. Formas de produção antes consideradas incompatíveis ou contraditórias entre si aparecem agora como como sistemas alternativos que "podem existir lado a lado, no mesmo espaço, de uma maneira que permita que os empreendedores capitalistas escolham à vontade entre eles” (HARVEY, 2012, p. 175). A flexibilização por meio das terceirizações e do funcionamento “em rede” das relações entre as empresas faz com que o modelo "patriarcal”, de pequenas firmas familiares que operam com base nas relações de parentesco (como nos mercados informais), negociem com empresas que funcionam pelo modelo "patrimonial”, com impérios hierarquicamente organizados, que, por sua vez podem estabelecer relações com aquelas de modelo "proletário", baseadas na compra e venda da força de trabalho em empresas 
capitalistas e fábricas.

No plano cultural, o "ecletismo das filosofias e gostos pós-modernos” (HARVEY, 2012, p. 175) ressoam o ecletismo das formas de produção que convivem no capitalismo contemporâneo: os fragmentos não tem qualquer relação com o todo, o universal é esvaziado e preenchido por conteúdos mutantes, contraditórios entre si, fugidios. A essa forma cultural, Harvey e Jameson dão o nome de pós-modernismo, uma vez que as linhas comuns que perpassam-nas guardam oposições ao modernismo, assim como Michael Hardt e Antonio Negri (2006) falam em uma formação imperial que se constituiu por oposição à economia e à política modernas. Assim como o capitalismo financeiro é uma economia de espelhos, uma vez que tudo se passa como se fosse o dinheiro que criasse ou desse origem a mais dinheiro, também o pós-modernismo é como o “espelho dos espelhos”, nas palavras de Harvey.

O pós-modernismo como uma voga no pensamento nos anos 1980 aceita o caos, o efêmero e o descontínuo sem tentar transcendê-los. Nesse sentido, dá continuidade ao modernismo uma vez que aceita o fragmentário, ao mesmo tempo em que rompe com ele ao exprimir um grande ceticismo diante de toda tentativa de buscar, conceber ou representar o eterno e o imutável ${ }^{109}$. Os fragmentos deixam de ser ou revelar a incompletude de si mesmos para se transformarem em totalidades desconectadas, sem mediação necessária.

A volatilidade, a instantaneidade, a descartabilidade e a descontinuidade, que são as formas pelas quais o capital circula, fizeram ruir os valores modernos (em sentido amplo) e se constituíram como nova modalidade da experiência social. O espraiamento da lógica da "moda" para toda a esfera do consumo (trocar de produtos com rapidez), os bancos eletrônicos e o dinheiro de plástico, a racionalização das técnicas de distribuição, a produção em pequena escala, a redução do espaço em função de meios de comunicação e transporte, tudo isso acelerou o tempo de produção, distribuição e consumo de mercadorias. Segundo Harvey, o pensamento pós-moderno foi influenciado por essa aceleração generalizada dos tempos de giro do capital, mimetizado-o.

Ao mesmo tempo, a cultura não apenas mimetizou a desterritorialização do capital, mas teve um papel fundamental na celebração das qualidades transitórias, uma vez que o campo da produção cultural (mídias, espetáculos, eventos, mesmo a arquitetura, a

109 Harvey (2012) faz um panorama do modernismo exatamente nesta chave e analisa mais de perto a arquitetura modernista. Para uma discussão sobre a relação entre o universal e o particular no modernismo brasileiro, cf. LIMA, 2012. 
publicidade, as campanhas políticas, etc) explora as tecnologias desenvolvidas para circulação intensa e rápida de capitais, mercadorias, pessoas e informações, enfatizando seu caráter aparentemente democratizante de levar a arte à classe popular. Nesse sentido, pode-se dizer que a cultura adentra a vida cotidiana como a forma de mediação de muitas relações sociais, não no sentido de que o pós-modernismo como movimento cultural preceda-as histórica ou logicamente, mas sim porque a lógica cultural, ao se massificar, se associa à vida cotidiana por meio do consumo - afinal é por meio dele que se alarga o fluxo contínuo de equivalentes (cf. SAFATLE, 2008).

Em outras palavras, arte e consumo não são mais contraditórios, mas um penetra no outro dando-lhe sua forma. Só há democratização da arte na medida em que esta se torna mercadoria, ao mesmo tempo em que as relações de produção passam a operar acionando mecanismos da produção cultural como sua imagem e como sua forma. A diferenciação, os estilos de vida, a valorização das diferenças estéticas, por exemplo estão na ambígua conjunção entre publicidade e arte.

O tempo curto dos vídeos da MTV, os traillers de filmes, as propagandas que juntam discursos banais completamente disparatados para vender produtos que em poucas semanas serão descartados (por saírem de moda ou por quebrarem) não revelam, em suas formas fragmentadas, uma ausência. Ao contrário são como mensagens completas que, portanto, superariam a falta de um sentido anterior, totalizante ou subjacente. No caso dos traillers de cinema, Jameson argumenta que estes se tornaram uma produção autônoma cujo efeito, no limite, é a desconexão completa com a história retratada no filme, como se o primeiro não se referisse ao segundo.

O que acontece aqui é que o que era um fragmento de narrativa, incompreensível sem o contexto narrativo como um todo, torna-se agora capaz, em si mesmo, de emitir uma mensagem narrativa completa. [...] Daí o esmaecimento do afeto no pós-moderno: a situação de contingência ou de falta de sentido, de alienação, foi ultrapassada por essa re-narrativização dos pedaços quebrados do mundo da imagem.

JAMESON, 2001, p. 171

Jameson identifica um duplo processo de colonização da economia pela cultura, e de engolfamento da produção cultural pela lógica da mercadoria. A imbricação entre esfera cultural e econômica é tal que, assim como já dizia Marcuse nos anos 1960, não há mais uma 
contradição entre ambas, a primeira não mais resta como alienação, como exterior à segunda $^{110}$. Assim como o capital financeiro adquire autonomia, supostamente prescinde da produção e do consumo e vive sem qualquer referência a conteúdos anteriores, o mesmo se passa com as formas culturais que adquirem o modelo dos fragmentos. A chamada crise da representação ou a crítica das grandes narrativas fazem com que não haja, no interior do pósmodernismo, a possibilidade de discuti-lo a não ser como um “ponto de vista” relativo, nunca sendo possível olhá-lo de fora e tratá-lo como condição histórico-geográfica.

É nesse sentido que o trecho citado de Jameson menciona o "esmaecimento do afeto": o que antes apontava os limites do capitalismo, como a alienação, agora aparece como “pedaços quebrados do mundo da imagem”, assim como Marcuse já falava sobre a eliminação das contradições, como se o predomínio do capital financeiro tivesse intensificado a dissolução da autonomia do estético (e esteticizado a economia).

Michael Hardt e Antonio Negri (2006) fazem uma análise da geopolítica mundial, a qual passou por transformações intensas desde a década de 1970 e culminou no "Império". Assim como Jameson e Harvey, os autores buscam as relações entre continuidade e transformação do mundo contemporâneo com relação ao momento histórico precedente. Ao mesmo tempo, inspiram-se em Gilles Deleuze e Félix Guattari para compreender o pósmodernismo (como ideologia, como forma de produção e como política).

Hardt e Negri, ao postularem a passagem da soberania para o império, retomam a relação entre Estado e capitalismo desterritorializado sobre a qual discutem Deleuze e Guattari (2010) ${ }^{111}$, e ao mesmo tempo retomam as análises materialistas dialéticas de Harvey e Jameson sobre as contradições do capital que se desenvolvem dialeticamente. É como se Hardt e Negri trouxessem as formulações de Deleuze e Guattari para um contexto histórico e conjugassem seu vocabulário com a relação discutida por Harvey e Jameson entre

110 Vale notar que o objetivo deste trabalho não é aprofundar este rico debate que vem sendo travado já há muitas décadas. A relação estabelecida por Harvey e Jameson são trazidas, aqui, como fonte de inspiração para pensar a hipótese de uma formação social capitalista que transforma as contradições em "diferenças” plasmadas e assim expulsar o negativo de si.

111 Em “O Anti-Édipo” (2010), Deleuze e Guattari mostram, a partir de diálogos com a etnologia, com a linguística e com a psicanálise, como o capitalismo é um acidente (no sentido de que não há nada de necessário ou teleológico em sua formação) que se funda na desterritorialização e descodificação dos fluxos desejantes. Primeiro, dizem, veio a representação imperial, a forma Estado; deveio então o capitalismo esquizofrênico que desterritorializa os fluxos codificados nas sociedades primitivas e recodificados pelo Estado. 
desenvolvimento do capitalismo e dimensão ideológica. O desdobramento do capital industrial em capital financeiro é aproximado do fenômeno da desterritorialização (cf. HARDT; NEGRI, 2006, p. 172).

Assim como Harvey faz um levantamento do modernismo e chama a atenção para sua dupla ênfase no efêmero e no eterno, Hardt e Negri tratam a questão por meio do conceito de soberania. A soberania do Estado-nação é marcada por uma crise, dizem os autores, que diz respeito à luta entre imanência e transcendência, entre os particulares e o universal. Essa crise marca diversos momentos históricos, e é resolvida de diversas maneiras a depender do ângulo pelo qual se observa. O colonialismo foi uma dessas soluções temporárias, quando os Estados deparam-se com uma profusão de povos e impõe sua força unitária e unificante ao criar o “outro” como aquilo que é diferente mas que pode e deve ser colonizado.

O projeto pós-modernista, segundo Hardt e $\mathrm{Negri}^{112}$, é uma crítica a um dos pólos da crise da modernidade (o universal) por meio do acento sobre as diferenças, e o efeito dessa crítica é uma eliminação da dialética entre universal e particular e entre transcendência e imanência ${ }^{113}$. O problema aparece quando não é apenas o pós-modernismo, uma corrente de pensamento, que procede dessa maneira: as estruturas de poder desde os anos 1980 também operam pelo vocabulário da diferença.

A discussão de Jameson sobre a colonização do mundo real pela cultura aparece em alguma medida quando Hardt e Negri apontam a correspondência entre o pensamento filosófico e artístico pós-moderno e o marketing. Ambos se interpenetram, de modo que a arte não guarda mais um lugar de alienação, mas uma vez produzida e reproduzida pela forma da mercadoria, a cultura fornece elementos para as práticas do mercado.

A ideologia do mercado mundial sempre foi o discurso antifundacional e antiessencialista por excelência. Circulação, mobilidade, diversidade e mistura são as condições que a tornam possível. O comércio junta as diferenças, e quanto mais, melhor! As diferenças (de mercadorias, de populações, de culturas e assim por diante) parecem multiplicar-se infinitamente no mercado mundial, que não ataca nada com tanta violência

112 Vale lembrar que Hardt e Negri dão maior notoriedade ao pós-modernismo que opera em determinadas esferas, como as relações internacionais, enquanto Jameson e Harvey acentuam a produção artístico-cultural e Boltanski e Chiapello o fazem no domínio do trabalho.

113 Esse argumento já aparecia no trabalho de Marcuse (1972) como uma ideologia, e não como uma superação real das contradições. A seguir, veremos como Zizek defende que a impressão que se tem de que não há mais contradições no mundo é a "nova forma" que a ideologia assume no mundo contemporâneo. 
como as fronteiras fixas: ele esmaga qualquer divisão binária om suas infinitas multiplicidades.

HARDT; NEGRI, 2006, p. 168

Uma nova forma de economia global descentralizada e desterritorializada, que “incorpora gradualmente o mundo inteiro dentro de suas fronteiras abertas e em expansão" (HARDT; NEGRI, 2006, p. 12) desestabiliza qualquer possibilidade de ruptura e de negação. Nada confina o reinado do Império, que aparece como natural e, por isso, eterno - "é assim que as coisas serão hoje e sempre”. Ao mesmo tempo, a forma desterritorializada (ou desenraizada do social) que o capitalismo assume pode conviver com tentativas de “reterritorialização”. As reterritorializações são como neoarcaísmos, que tentam restabelecer vínculos (seja de maneira espontânea ou intencional e voluntária), como os nacionalismos, as minorias étnicas ou os grupos de bairro. Mas estas tentativas são a contraparte da desterritorialização e não sua negação. As reterritorializações não são um verdadeiro retorno ao passado, mas uma colocação, no interior da desterritorialização, de elementos aparentemente incompatíveis com a lógica desterritorializante do capital. Como dizem Deleuze e Guattari (2010, p. 347), a reterritorialização é o processo de trazer para dentro do capitalismo seus limites.

A expulsão do negativo e da dialética, apresentada por todos esses autores, não significa, como já defendia Marcuse, uma eliminação real ou uma conciliação das contradições. Ou seja, embora o capitalismo pareça proceder de forma democrática ao difundir o consumo de massas por todo o globo terrestre e por meio disso proceder tanto incorporando as diferenças como popularizando bens e serviços (sobretudo culturais) que antes eram restritos às elites, não se verifica de fato uma superação de problemas sociais, econômicos e políticos. Como dizem os autores acima, o capitalismo conseguiu sobreviver à crise dos anos 1970 (que era tanto uma crise econômica quanto uma crise de legitimidade como argumentam Boltanski e Chiapello) por meio do esvaziamento de conteúdos, restando apenas formas, da ênfase no fugidio, do efêmero e da diferença em detrimento da relação entre estas e o eterno, o imutável e o universal.

Logo, podemos dizer que a supressão da dialética tem um caráter ideológico, que consiste em, ao expulsar o negativo do seio do social, apagar do horizonte a possibilidade de transformação. Isso está profundamente relacionado com a crítica ao conceito de ideologia 
como um véu mistificador que encobre a realidade pois, diz-se hoje, não se pode mais adotar um ponto de vista externo e acusar grupos sociais (inclusive povos não ocidentais) de vivenciarem o mascaramento da sociedade. Na verdade, esta perspectiva (presente entre muitos que se auto-intitulam pós-modernos) está associada à fagocitação da crítica pelo capitalismo, pois agora a crítica está posta, qualquer um pode fazê-la e nada mais parece estar “escondido” das pessoas.

\section{3. Ideologia}

Não é de se estranhar, afirma Slavoj Zizek (1996b), que estejamos aptos a pensar em catástrofes ambientais causadas pelo desenvolvimento tecnológico, político, científico e econômico mas não consigamos pensar em uma transformação social verdadeiramente revolucionária, no sentido de transformar as condições de produção da catástrofe (e como fica então o decrescimento que se propõe a pensar transformações? Sobre isso voltaremos no final deste capítulo). Mas como abordar a questão da ideologia em um mundo em que esta não é mais um véu que recobre e inverte a realidade? Afinal se o capitalismo contemporâneo trouxe para a superfície todos os pontos de vista como particularidades diferenciantes que coexistem, como buscar o ponto de vista "correto" a partir do qual poderíamos "ver" a realidade escondida?

Para responder a essa pergunta, Zizek (1996b) faz uma inversão da questão: “a questão é evitar o fascínio propriamente fetichista do 'conteúdo' supostamente oculto por trás da forma: o 'segredo' a ser revelado pela análise não é o conteúdo oculto pela forma [...], mas, ao contrário, o 'segredo' dessa própria forma.” (p. 297 - grifos do autor) ${ }^{114}$. A forma aqui em questão é a forma de existência e representação social: ela não mais esconde os conflitos, e sim apresentam-nos sob nova forma; trata-se de compreender, portanto, essa forma social pósmoderna.

A busca pelo segredo da forma caracteriza também a obra de Lévi-Strauss. Diante dos dois mapas desenhados por dois índios de uma mesma aldeia, o antropólogo francês defende

114 Marx e Freud já teriam procedido dessa maneira ao discorrer sobre o fetichismo da mercadoria e sobre o sonho, respectivamente. O entendimento teórico da forma do sonho não consiste em desvendar seu conteúdo oculto os pensamentos latentes do sonho, a partir do conteúdo manifesto, mas sim na resposta à pergunta: por que os pensamentos latentes do sonho assumiram essa forma, por que foram transpostos para a forma de um sonho? 
que o "problema” de existir duas representações distintas - elaboradas por dois indivíduos pertencentes a dois subgrupos de uma mesma aldeia - não é resolvido por uma foto aérea. Isso equivaleria a dizer que cada subgrupo têm uma visão falseada da realidade apreendida pela foto, instrumento científico. O que Lévi-Strauss sugere, continua Zizek, é que a diferença das duas totalidades representadas implica a referência a um "núcleo traumático”, que é o "desequilíbrio nas relações sociais que impedia a comunidade de se estabilizar num todo harmonioso” (ZIZEK, 1996a, p. 31). De forma simplificada, é como se a dupla representação remetesse a uma cisão social.

Para que esse argumento fique mais claro, retomemos o pensamento do próprio LéviStrauss. Quando discute o mana (LÉVI-STRAUSS, 2003), seu argumento é que Marcel Mauss conseguiu explorar o modo como se relacionam real e "realidade”. Quando dois pontos de vista são aparentemente irreconciliáveis (como o caso entre o etnógrafo e um povo indígena), Lévi-Strauss diz que a oposição entre “nós” e os “outros” só pode ser superada no terreno do inconsciente, que é “o termo mediador entre mim e outrem” (Ibid., p.28). O problema é que o inconsciente é inacessível enquanto tal. Mas Lévi-Strauss, (assim como Lacan (1996)) recusa a "saída” relativista segundo a qual nada poderia ser feito diante de tal impossibilidade, senão assumir que o modo como vejo outrem é apenas um modo de ver.

Lévi-Strauss tratou esse modo de ver como a forma consciente a partir da qual se pode ter acesso à "realidade subjacente” (2003, p. 35), e a noção de suplemento ou significante flutuante como os pontos de ligação estrutural entre a estrutura simbólica e o inconsciente. Mauss teria fracassado porque ao invés de explicar o mana ou o hau como significantes flutuates, acabou rendendo-se às teorias indígenas. A proposta de Lévi-Strauss é que essas noções (ou ainda os nossos termos de valor zero como “coisa” e "troço") revelam $a$ inadequação entre significante e significado. Para compreender o mundo, o homem sempre dispõe de um excedente de significação, que ele organiza segundo leis do pensamento simbólico. Mas essa organização requer um "suplemento" (ou significante flutuante), tal como o mana e o hau, para que “o significante disponível e o significado assinalado permaneçam entre si na relação de complementaridade que é a condição mesma do exercício do pensamento simbólico” (LÉVI-STRAUSS, 2003, p. 43).

Inspirado em Lacan, Zizek argumenta que não existe realidade sem espectro; se a simbolização nunca consegue abarcar totalmente o real (ou o significante de Lévi-Strauss), 
isso não significa que o real esteja escondido, mas sim que o real retorna sob a forma de espectro. Então poderíamos dizer que o mana é o indeterminado que coexiste (determina e é determinado) com o simbólico, e não aquilo que dá acesso a um mundo subjacente. Mais precisamente, Zizek inverte o raciocínio estruturalista: para que a "realidade” (o simbólico) emerja, algo é foracluído dela, ou seja, a realidade é estruturada a partir do recalcamento de parte do real. Ao mesmo tempo, aquilo que é recalcado volta à superfície, sob forma espectral. Logo, o real não está por trás, mas está na própria “realidade”, como um espectro. Uma crítica da ideologia não precisa, portanto, buscar aquilo que se afasta da realidade, mas sim aquilo que está nela.

Se a inspiração de Zizek é o estruturalismo, não estaríamos diante de uma "mera” reelaboração de teorias abstratas, que recusam a história e que podem ser igualmente “aplicadas” para todas as relações sociais? ${ }^{115}$ Para fugir disso ou de interpretações como as de Derrida $^{116}$, Zizek sugere um retorno a Marx. Assim como Lévi-Strauss, Zizek defende que a relação dialética entre o real e a "realidade” não está presente apenas entre “nós”, mas é constitutiva do sujeito e de todas as realidades sociais. No capitalismo, o que foi recalcado e que aparece sob forma espectral (e que o constitui) é um elemento histórico: as relações de dominação e servidão. Para entender esse recalcamento, precisamos passar pela noção marxista de fetichismo da mercadoria.

O fetiche da mercadoria geralmente é definido como a relação entre pessoas que assume a forma de relação entre coisas. Se Marx, como já vimos, estava preocupado em desvendar o segredo da forma mercadoria, vamos partir - assim como faz Zizek e o próprio Marx - da forma do fetiche, que é a relação entre coisas. Considerando-se apenas esta relação, o fetiche é um efeito estrutural: as relações de troca entre coisas produzem como efeito coisas que aparecem como formas naturais. Uma mercadoria A só pode expressar seu valor em referência a outra mercadoria $B$, mas o valor de $A$ se expressa no corpo de $B$, em seu valor de uso. "Em outras palavras, o corpo de B transforma-se, para A, no espelho do seu valor" (ZIZEK, 1996b, p. 308). O corpo do ouro historicamente foi definido como a mercadoria que seria o equivalente geral para o valor de todas as outras mercadorias (mercadoria dinheiro),

115 Vale lembrar que essa é uma leitura caricatural do estruturalismo, mas que circula ainda hoje nas ciências humanas.

116 Derrida reelabora, no Gramatologia (2004), a noção de suplemento a partir da abordagem desconstrucionista, supostamente superando Lévi-Strauss, Lacan e os demais estruturalistas que teriam ficado "presos" à armadilha da origem da estrutura. 
mas o efeito desse espelhamento generalizado é a aparência de que o dinheiro é aquilo que atribui valor às outras mercadorias.

Tendo compreendido o fetiche na relação entre coisas, qual a relação entre esta relação e a relação entre as pessoas? Segundo Zizek, no capitalismo, a relação entre as pessoas não é "fetichizada”, apenas a relação entre as mercadorias. As pessoas que entram em relação são "livres" e podem entrar ou sair das relações de troca quando quiserem, e os outros sujeitos só lhes interessam na medida em que possuem uma mercadoria que lhes satisfaça. Por oposição, as relações entre senhor e escravo eram totalmente fetichizadas (relações de dominação e servidão definem os sujeitos) enquanto a produção era "natural”, ou seja, não era voltada para a troca tal como acabamos de descrever.

Na passagem do feudalismo para o capitalismo, houve um recalcamento das relações de dominação e exploração entre o senhor e o escravo, que agora voltam sob a forma das relações sociais que aparecem como relações entre coisas.

[F]ormalmente, parecemos estar lidando apenas com sujeitos livres, cujas relações interpessoais estão isentas de qualquer fetichismo; a verdade recalcada - a da persistência da dominação e da servidão - emerge num sintoma que subverte a aparência ideológica de igualdade, liberdade e assim por diante. Esse sintoma, o ponto de emergência da verdade sobre as relações sociais, são precisamente as 'relações sociais entre as coisas'.

ZIZEK, 1996b, p. 310

O pós-modernismo é sintoma de uma transmutação maior, diziam Hardt e Negri. Vimos acima que a transformação em jogo diz respeito à eliminação da relação entre universal e particular, eterno e efêmero, entre significante e significado, restando apenas os fragmentos. Zizek traz um elemento adicional que acompanha essa démarche: se tudo é sinal de um sinal, qualquer tentativa de buscar uma palavra oficial é tomada como autoritária e a saída encontrada é a “ironia”. Como afirma Vladimir Safatle (2008), a crítica pós-modernista foi uma grande responsável por fazer proliferar "estruturas normativas duais”, ou seja, o processo de socialização pela internalização simultânea de duas estruturas simultâneas e contraditórias entre $\mathrm{si}^{117}$. A ironia corresponde à crise de imagens privilegiadas, que estariam em posição de ideal; diante da destruição desse lugar privilegiado (seja na formação do sujeito, na economia, ou na cultura), pode-se cair em um distanciamento irônico com relação

117 Manuela Carneiro da Cunha (1987) e Roberto Schwaarz (2008) trouxeram essa discussão para solo brasileiro ao refletir sobre a coexistência contraditória entre liberalismo e escravidão. 
a todo "papel identitário que determina um fazer social” (SAFATLE, 2008, p. 105). Tudo se passa, portanto, como se apenas houvesse máscaras ${ }^{118}$.

O fenômeno pelo qual o capitalismo lança suas formas e normas para imediatamente fragilizá-las, ou pelo qual desterritorializa o desejo (por oposição ao desejo inscrito no socius) como diziam Deleuze e Guattari (2010) é o cinismo. Houve um momento histórico em que o cinismo era a rejeição popular à ideologia oficial: por meio do riso e de momentos de exceção, as relações sociais e as normas eram postas em xeque. Mas a transgressão cínica da lei, neste sentido, já carrega uma contradição uma vez que, findo o momento de exceção, a lei volta a funcionar. Isso significa, segundo Safatle, que essa transgressão não é uma supressão da lei, e sim uma de suas partes constitutivas.

A diferença histórica entre esse tipo de cinismo e o cinismo como ideologia do capitalismo contemporâneo é que aquilo que aparecia em momentos pontuais e restritos (a ironia frente à lei) torna-se hegemônico ${ }^{119}$. Nessa mesma direção, Vladimir Safatle afirma que a falência da crítica está relacionada, na verdade, a sua realização cínica:

O capitalismo não exigiria mais espécie alguma de crença cega nos conteúdos normativos que ele próprio apresente. Crença que deveria ser compreendida como defesa de um princípio seguro de indexação entre critérios de validade de aspirações universais e situações da dimensão prática. Ou seja, poderíamos todos tomar distância dos conteúdos normativos do universo ideológico capitalista porque o próprio discurso do poder já ri de si mesmo. No entanto, e este é o mais importante, essa aparente ausência de legitimidade seria o verdadeiro núcleo de sua força. Isso a ponto de podermos dizer que sua crise de legitimidade seria seu núcleo motor.

SAFATLE, 2008, p. 92.

E em que medida o cinismo está relacionado ao segredo da forma da mercadoria? Se o fetiche é um sintoma do recalque das relações sociais, o cinismo aparece quando o recalcado volta: todos sabem que existem relações sociais “para além” da relação entre coisas, como

118 Ou, como diz o antropólogo Clifford Geertz (1989), tartarugas de tartarugas: “a análise cultural é intrinsecamente incompleta e, o que é pior, quanto mais profunda, menos completa” (p. 20).

119 A expulsão dos universais, da territorialização, da totalidade são como o fetiche do capital que Marx (1984b, 1986) anunciava: é a pura forma que toma corpo. As relações que a constituem são transformadas absolutamente. E se já era possível identificar um processo de abstração no século XIX, não significa que haja uma completa novidade no mundo contemporâneo. Aquilo que pode-se identificar como novidade é a generalização da abstração a ponto de nada mais parecer lhe escapar. Tudo parece ter sido transformado em parcialidades, tudo são pontos de vista; nada pode ser exterior, anterior, superior às diferenças. 
mostra por exemplo David Harvey ao falar da convivência de modos de produção alternativos e antes contraditórios (que teriam sido “superados” uns pelos outros mas que agora aparecem como possibilidades concretas e cínicas para o capital continuar a circular). Ao trazer para dentro de si seus limites (sob novas formas, como apresentara Marcuse), as contradições parecem ter se inviabilizado enquanto tais e a ideologia não seria mais uma esfera separada que expressa o negativo da sociedade.

Logo, a ideologia não está mais escondida; a ideologia não é mais como um ilusão, mas é uma fantasia, diz Zizek (1996b, p. 323):

A ideologia não é uma ilusão de tipo onírico que construamos para escapar à realidade insuportável; em sua dimensão básica, ela é uma construção de fantasia que serve de esteio à nossa própria 'realidade': uma 'ilusão' que estrutura nossas relações sociais reais efetivas e que, com isso, mascara um insuportável núcleo real impossível ([...] uma divisão social traumática que não pode ser simbolizada). A função da ideologia não é oferecer-nos uma vida de escape de nossa realidade, mas oferecer-nos a própria realidade social como uma fuga de algum núcleo real traumático

A transformação das contradições em lados alternativos e a dissolução da alienação da autonomia de certas esferas, sobretudo a artística, fizeram com que a realidade deixasse de ter um espaço escondido. Desvendar o segredo da forma, como dizia Zizek, é entender como a explosão da realidade (se é que podemos assim chamar a proliferação de textos que dão voz aos outros, a quantidade de filmes que contam a história de pessoas fracassadas, ou mesmo a ascensão de um governo de esquerda no Brasil que concilia as contradições de classe, ou seja, os fenômenos que trazem aos nossos olhos o que antes parecia estar escondido) é uma maneira de dar sustentação a nossa realidade. A aparência de que tudo está dado, que tudo está diante de nós e que por meio das redes são possíveis inúmeras relações, tudo isso nos distancia do "núcleo traumático" e nos faz viver em uma sociedade cindida, sobre a qual sabemos da existência, mas mesmo assim continuamos vivendo.

\section{4. As contradições do decrescimento}

Se conseguimos visualizar uma catástrofe ecológica mas fechamos os olhos para a possibilidade de transformação social, o que dizer de um movimento como o decrescimento que, diante da iminência de desastres ambientais defende que outro mundo é possível? E 
sobre a forma nebulosa, não seria ela uma resposta ao pós-modernismo, à redução do social a um amontoado desordenado de fragmentos? A insistência na criação e manutenção de relações (que sejam humanizadas, felizes, festivas, conviviais, etc) é uma maneira de recusar as grandes narrativas, os movimentos de massa, os programas políticos centralizados e bem estabelecidos, e ao mesmo tempo questionar a atomização de coletivos e indivíduos com seus modos de vida que em nada poderiam contribuir para a transformação social em larga escala.

O decrescimento procede de maneira análoga a muitas teorias sociológicas e antropológicas que por um lado abrem mão das noções de sociedade e de indivíduo em função da explosão de relações sociais que escapam aos limites bem estabelecidos, determinados por autoridades científicas, mas que por outro lado também buscam escapar ao relativismo e elaborar conceitos para abarcar a relação entre parte e todo, entre particular e universal. Essa é a leitura que Mauro Almeida (2003) realiza a respeito das propostas "hermenêuticas": para não cair em um solipsismo relativista ou em um tribunal da razão, autores enveredaram para a construção de uma “conversa”, mas contraditoriamente o efeito é uma recusa da possibilidade de "qualquer procedimento num espaço de negociação com procedimentos compartilhados”. (p. 15).

Segundo David Harvey, esse tipo de abordagem tenta fugir das grandes narrativas e cultiva uma possibilidade de ação que é limitada, no sentido que "acentua a comunidade e a localidade, as resistência locais e regionais, os movimentos sociais, o respeito pela alteridade, etc”. Seria como uma tentativa de extrair um mundo possível em meio aos inúmeros mundos. O problema, continua Harvey, é que concretamente as pequenas lutas que são tentativas continuas de fugir à força universalizadora do capital, não consigam fazer frente a ele por restarem parciais.

Vimos nos capítulos precedentes como o decrescimento é uma mobilização que tenta, de diversas maneiras (meios de comunicação, militância multi-engajada, redes de produção, distribuição e consumo de alimentos, etc) colocar em prática uma crítica ao crescimento, ao consumismo, à publicidade, à destruição do meio ambiente. Mas é exatamente o modo como se procede para realizar essas pertinentes críticas que acaba jogando contra o propósito do decrescimento - e as bases para esse fenômeno já estavam lançadas pela nova esquerda nos anos 1960, com a expulsão das contradições sociais em nome de problemas supostamente maiores e exteriores que subjugavam toda a população, sem distinção de classe. 
Vale notar que, diferente de Almeida e Harvey que apontam a contradição no nível da ação (a impossibilidade de transformar a multiplicidade de movimentos em uma mobilização mais geral porque a ênfase nas partes prevalece), o que buscamos mostrar é outra dimensão do aspecto ambíguo do decrescimento. Menos do que o descolamento entre as teorias e as práticas (que é decerto um procedimento válido, mas que já vem sendo trabalhado por alguns críticos), a contradição aqui em jogo diz respeito ao duplo movimento que opera no interior do decrescimento: as críticas e a possibilidade de ruptura se concretiza por meio de uma formação que recusa o negativo ou o indeterminado; ao mesmo tempo, os métodos desenvolvidos são, a todo momento, a contra-face desta recusa, como uma permanente fuga, com incessantes desvios, mudanças de rumo, porque as lutas são parciais, locais, na iminência da captura, sucumbe-se aqui, foge-se ali e assim indefinidamente. Em outras palavras, a contradição não quer dizer que o movimento seja cooptado, mas que as fugas se constroem de uma maneira que negam aquilo que é essencial para a fuga, e que lhe dá origem, que é o indeterminado; ao mesmo tempo, enquanto se coloca a necessidade de romper com o crescimento. A noção de contradição é usada aqui menos como uma forma de exprimir fases consecutivas do movimento e mais como uma maneira de elucidar dois caminhos contrários que, apesar de sua contrariedade, coexistem eliminando-se.

Diante de tudo o que foi apresentado nos capítulos precedentes, vejamos sucintamente como se dá isso que chamamos aqui de contradição. A negação do sistema, ao se concretizar por meio da profusão de alternativas locais, apresenta outras modalidades de relação social que não sejam mediadas pelas determinações econômicas, ao mesmo tempo em que a positivação dos outros modos de vida possíveis contradiz o desejo do outro desconhecido. Isso se intensifica com as estratégias de religar as pequenas fugas, pois a mesma ação que visa provocar uma ação em larga escala acaba sobredeterminando os espaços vazios; ou seja, por meio das estratégias nebulosas que tentam escapar às relações colocadas pelo capitalismo, qualquer “outro” já encontra-se preestabelecido. Vejamos com mais atenção cada uma dessas contradições.

Em primeiro lugar, a contradição do decrescimento se desdobra do conflito entre “criticar” o crescimento e "propor" coisas novas que consigam colocar em prática outro mundo possível. A relação entre crítica e ação aparece como uma oposição, uma vez que a primeira é considerada sinônimo de negação e a segunda, de positividade. Não se trata, por 
exemplo, de discutir métodos de destruir indústrias e máquinas, de discutir mecanismos de greve ou de organizar setores da sociedade. É como se a crítica fosse negar o existente e a ação política fosse coloca em prática uma alternativa. Isso significa que agir politicamente não é sinônimo apenas de manifestar descontentamento. Entra para a esfera da ação toda uma preocupação em fazer viver o outro mundo possível no seio de um mundo ainda não transformado. A crise pela qual o decrescimento passa em Lyon é efeito disso: hoje muitos militantes se dizem descontentes com a palavra “decrescimento" porque ela é negativa e preferem aderir ao movimento das Cidades em Transição. Seguem um manual que não apenas discute questões ambientais mas que, principalmente, indica passos para construir a mobilização, conquistar novos adeptos e mediar conflitos (cf. HOPKINS, 2010). A ênfase na prescrição é contraditória, portanto, porque ao partir de uma separação entre crítica e ação faz com que o “outro mundo possível” (ou outro desenvolvimento possível, ou qualquer que seja a expressão adotada pelas pessoas engajadas) seja povoado por prescrições, eliminando do horizonte aquilo que é indeterminado.

Para que isso fique mais claro, pensemos em como a relação de posição entre crítica e ação aparece na vida cotidiana dos militantes. Ela provoca uma espécie de angústia, uma maneira subjetiva de se "desculpar" socialmente frente à impossibilidade de viver integralmente de maneira alternativa (afinal, é impossível apenas consumir orgânicos, não comprar absolutamente nada em supermercados). Essa impossibilidade torna-se antes uma questão moral que pode ser resolvida pelo maior engajamento e militância e perde seu efeito de crítica social. Ao transformar a impossibilidade de adotar um modo de vida em uma questão individual, o limite do crescimento (esse outro modo de vida) se transforma em possibilidade no interior do crescimento ${ }^{120}$.

Em suma, a contradição nasce quando a oposição entre crítica e ação faz com que a ênfase nesta última determine de antemão qual é este outro mundo possível, eliminando do universo do crescimento as contradições que ele próprio carrega em si. Se a crítica ao crescimento nasce como um negativo, ela logo expulsa de seu seio a potência desse negativo (do indeterminado) ao plasmá-lo em uma profusão de propostas de ação.

120 Uma questão não resolvida nos circuitos do decrescimento é aquilo que se convencionou chamar de greenwshing, que é a adoção do discurso ecologicamente correto por empresas que nada tem de ecológicas. Para uma discussão de como o capitalismo se apropria facilmente de movimentos de resistência transformando-os em nichos de mercados, ou segmentos consumidores, cf. SAFATLE, 2012. 
A segunda via por meio da qual o decrescimento se contradiz é a elaboração de um aparato (a organização em nebulosa, por exemplo) que pretende dar conta da realização dessas alternativas. Como apontam Boltanski e Chiapello (2009), a noção de sociedade em rede que explodiu nos anos 1980, seja como forma de experiência social, seja como teoria, implicava em trazer todas as esferas sociais para dentro das teias do capitalismo. Em outras palavras, por meio das conexões, tudo está ligado e nada mais “escapa” a uma rede. Até mesmo a pobreza extrema parecia corroborar a tese de um mundo conectado por inteiro: não mais vistos como uma classe em oposição à burguesia, os setores sociais miseráveis eram “excluídos” das redes.

A transformação da ação política em modos de fazer acontecer o outro mundo possível (logo, em modos de vida) foi acompanhada por investimentos em relações entre pequenos e frágeis coletivos que poderiam colocar em marcha a concretização do mundo que se espera. A ênfase nas relações passa pelo mesmo vocabulário acionado pelo universo empresarial: redes, projetos, pessoas que tem absoluta mobilidade, indivíduos que enlaçam coletivos de pessoas e por meio deles que se estabelecem relações sociais. Esse é o modo encontrado, no mundo do trabalho, de atenuar conflitos e contradições e de fazer coexistir formas de produção e de trabalho opostas entre si. Se o decrescimento é como uma nebulosa, ele incorpora em si toda a ação e todo pensamento, mesmo coletivos distantes e sem qualquer ponto em comum. As pesquisas e investimentos por parte dos militantes sobre formas de comunicação não violentas encerram a nebulosa: tudo pode entrar nela, mas nada pode destruí-la, a violência deve ser controlada (autocontrolada).

Por fim, pode-se afirmar que esse duplo procedimento acarreta, ainda, em uma terceira contradição que consiste em aproximar a forma da crítica aproximação à forma de funcionamento do objeto criticado. E, mais do que isso, ao negar o negativo, sai de cena o outro mundo possível e ficam apenas com o possível. Isso não significa que todos os esforços envolvidos na execução do decrescimento sejam desprovidos de sentidos. Ao conseguir autonomia, por exemplo, concertando suas próprias bicicletas, criando suas composteiras, fazendo seus próprios produtos de higiene como cremes hidratantes, os militante definitivamente consegue colocar em prática, ao menos parcialmente, um estilo de vida que aponte para momentos de fuga e de ruptura com as relações sociais mediadas pelas relações entre coisas. O ponto é que a prescrição e a forma de coordenar as alternativas nascem das contradições do capitalismo mas inflacionam essas contradições ao fazer da potência de 
irrupção da negação um manual de alternativas.

Assim como nos anos 1960 e 70 a nova esquerda tentava expulsar para fora da ação política e das concepções de mundo o marxismo, o Partido Comunista, a militância proletária, sempre sob o argumento de uma transformação social sem precedentes perante a qual não fazia mais sentido usar esses termos, a nebulosa do decrescimento concretizou uma forma de crítica social na qual o fora não tem mais espaço, embora ela própria se origine na potência desse fora, por meio da crítica à crítica e pela maneira de organizar as relações entre as alternativas locais.

Como assevera David Harvey (2012, p. 320) a esquerda ajudou a criar a “confusão” que marca as relações sociais contemporâneas. A "nouvelle gauche”, ao tentar se libertar das “algemas duais da política da velha esquerda”, acarretou em um abandono do proletariado como instrumento de mudança e do materialismo histórico como método de análise. O problema disso, completa o autor, foi a perda da capacidade de autocrítica, bem como da crítica aos processos sociais de transformação que estão na base de sua emergência. Isso significa que a nova esquerda não fracassou porque seus atores foram cooptados e se transformaram em eminentes nomes do status quo. O que a nova esquerda fez foi, ao ser gerada pela negação do capitalismo, tirar de si a potência da negação (bem como a noção de contradição). A noção de alternativa atualiza esse procedimento ao se projetar como o outro do crescimento, mas eliminar este outro de si em sua realização.

Vimos como isso ocorre no interior do capitalismo: a fluidez das redes, por exemplo, é uma forma de garantir que qualquer possibilidade de relação social seja incorporada ao capitalismo com muita facilidade, sem que corra o risco de lhe fazer uma oposição - as relações deixam de ser perigosas. O capitalismo incorpora a forma da crítica como seu motor de funcionamento e tudo parece se assentar e encontrar um espaço em seu interior; logo, não resta mais um espaço de alienação que negue-o. Paralelamente, os movimentos que se opuseram à economia e à política vigentes contribuíram enormemente com a formulação da incorporação da crítica como meio de existência. Os pequenos gestos, os modos de vida, a politização o cotidiano, a concepção de ação política não mediada pela contradição de classe, tudo isso contribuiu para tirar a fratura social de cena. Uma vez que a sociedade se tornou massificada (como essas perspectivas de esquerda insistiam em concordar e agir em nome dela), era preciso não mais mostrar que todos estão sob o mesmo jugo, mas mostrar que todos 
podem viver de outra maneira. Agora, todas as outras maneiras parecem ter encontrado sua forma de realização, e daí para se converterem em novo nicho de mercado, o caminho é muito curto.

A forma de concretizar a outra sociedade que não seja organizada pelo decrescimento coloca em risco, portanto, o potencial do desconhecido, já que o delimita (por meio das alternativas) e prescreve formas de relação que encaixam qualquer outra novidade, eliminando sua potência de violentar o existente (por meio da nebulosa que recusa delimitações). Mas ao mesmo tempo, as “novas” formas de fazer política, a “nova” esquerda ou o tom de novidade em geral que paira entre militantes aponta para uma ânsia pelo novo, e que, portanto, não pode estar dado. Por isso, como já dizia Herbert Marcuse, a transformação social deve ser catastrófica. 


\section{Referências Bibliográficas}

ACCIOLY, I. A consciência ambiental do capitalPassa Palavra, 19 ago. 2012. Disponível em: <http://passapalavra.info/?p=63149>. Acesso em: 23 ago. 2012.

ALMEIDA, M. W. B. Relativismo antropológico e objetividade etnográfica. Campos. Revista de Antropologia Social, v. 3, p. 9-30, 2003.

ALONSO. As teorias dos movimentos sociais: um balanço do debate. Lua Nova, v. 76: 4986, 2009, 2009.

ALONSO, A.; COSTA, V. Ciências Sociais e Meio Ambiente no Brasil: um Balanço Bibliográfico. Revista Brasileira de Informação Bibliográfica em Ciências Sociais, v. 53, 2002.

ALTER INITIATIVES ! Travailler dans un milieu alternatif, possible ? Disponível em: <http://alterinitiatives.over-blog.com/article-36711930.html>. Acesso em: 24 abr. 2012.

ALTHUSSER, L. Aparelhos ideológicos de Estado. In: ZIZEK, S. (Ed.). Um mapa da ideologia. Rio de Janeiro: Contraponto, 1996.

ALTHUSSER, L. A querela do humanismo (1967). Crítica Marxista, v. 9, 1999.

ANDERSON, P. Considerações sobre o marxismo ocidental. São Paulo: Boitempo, 2004.

ARIĖS, P. La décroissance, un mot-obus. La Décroissance, abr. 2005.

ARVON, H. Le gauchisme. Paris: PUF, 1977.

Atelier 1: Les habits neufs du développement. Actes du colloque. Anais... In: DÉFAIRE LE DEVELOPPEMENT, REFAIRE LE MONDE. Paris: Le Monde Diplomatique; Unesco; Most; La Ligne d'Horizon, 28 mar. 2002.

BAYON, D.; FLIPO, F.; SCHNEIDER, F. La Décroissance, 10 questions pour comprendre et en débattre. Paris: La Découverte, 2010.

BERNARD, M. Que la montagne est belle. Silence, v. 331, jan. 2006.

BERNARD, M. (Dé)marches à franchir. Silence, v. 372, p. 4, out. 2009a.

BERNARD, M. Qui trop embrasse, mal étreint. Silence, v. 372, p. 15, out. 2009b.

BERNARD, M.; CHEYNET, V.; CLÉMENTIN, B. (EDS.). Objectif décroissance vers une société harmonieuse. Paris; Montréal; Lyon: Parangon-L’Aventurine ; Éd. Écosociété ; Silence, 2003.

BESSON-GIRARD, J.-C. Decrescendo cantabile: petit manuel pour une décroissance harmonique. Lyon: Parangon, 2005.

BESSON-GIRARD, J.-C.; LATOUCHE, S. Pourquoi Entropia? Entropia, v. 1, 2006.

BOLTANSKI, L.; CHIAPELLO, È. O novo espírito do capitalismo. 1. ed. São Paulo: WMF Martins Fontes, 2009.

BONAL, C. Quoi de neuf dans le dico? Libération, 12 jun. 2009.

BOSTRÖM, M. et al. Studying political consumerismPolitical Consumerism: Its motivations, power, and conditions in the Nordic countries and elsewhere. Anais... In: 2ND INTERNATIONAL SEMINAR ON POLITICAL CONSUMERISM. København: Nordisk Ministerråd, 2004.

BRAMWELL, A. Ecology in the 20th century: a history. New Haven: Yale University Press, 1989.

CANS, R. Petite histoire du mouvement écolo en France. Paris: Delachaux et Niestlé, 2006.

CARDOSO, I. Maio de 68: o advento do individualismo e da heteronomia. Tempo Social, v. 1, n. 1, 1989.

CARNEIRO DA CUNHA, M. Sobre os silêncios da lei: lei costumeira e positiva nas alforrias 
de escravos no Brasil do século XIX. In: Antropologia do Brasil. São Paulo: Brasiliense, 1987.

CASTORIADIS, C. Capitalisme moderne et révolution. Tome 2. Le mouvement révolutionnaire dans le capitalisme moderne. Paris: UGE, 1979.

CÉRÉZUELLE, D. Écologie et liberté - Bernard Charbonneau précurseur de l’écologie politique. Lyon: Parangon, 2006.

CÉRÉZUELLE, D. Le sens de la terre chez Bernard CharbonneauActes Colloque.

Anais... In: BERNARD CHARBONNEAU: HABITER LA TERRE. Pau: Université de Pau et des Pays de l'Adour, 2012.

CHARBONNEAU, B. Le Systhème et le Chaos. Paris: Éditions Anthropos, 1973.

CHARBONNEAU, B. O jardim de babilónia. Porto: Edições Afrontamento, 1988.

CHARBONNEAU, B. Finis Terrae. Lyon: À plus d'un titre, 2010.

CHARBONNEAU, B.; ELLUL, J. Diretivas para um manifesto personalista. Espiritualidade Libertária, v. 3, n. 1, p. 136-168, 2011.

CHARBONNEAU, J. P.; RODES, M. Ecologia social. São Paulo: EPU: EDUSP, 1979. (Nota técnica).

COLLOGHAN, M. La Rôtisserie, repas alternatifs et solidaires. Silence, v. 362, nov. 2008.

CORRÊA, F. Balanço crítico acerca da Ação Global dos Povos no Brasil (4)Passa Palavra, 19 ago. 2011. Disponível em: <http://passapalavra.info/?p=42782> . Acesso em: 21 ago. 2011.

DALTON, R. J. The green rainbow : environmental groups in Western Europe. New Haven: Yale University Press, 1994.

DARRI, M. Le retour des anti-pub. L'Echos des savanes, abr. 2006.

DEBORD, G. The society of the spectacle. Nova York: Zone Books, 1995.

DÉBOULONNEURS. Face à l'invasion publicitaire. Lyon, [S.d.].

Décroissance-Elections.

DELÉAGE, J.-P. Une histoire de l'écologie. Paris: La Découverte, 1991.

DELÉAGE, J.-P. En quoi consiste l’écologie politique? Écologie et Politique, v. 40, p. 21-30, 2010.

DELEUZE, G.; GUATTARI, F. Selvagens, bárbaros, civilizados. In: O anti-Édipo: capitalismo e esquizofrenia. São Paulo: Editora 34, 2010.

DERRIDA, J. Gramatologia. São Paulo: Perspectiva, 2004.

DI GIOVANNI, J. R. A estratégia e seus outros: notas sobre o Fórum Social Mundial. Perifèria, v. 15, dez. 2011.

DUBUISSON-QUELLIER, S.; BARRIER, J. Protester contre le marché: du geste individuel à l'action collective. Le cas du mouvement anti-publicitaire. Revue Française de Science Politique, v. 57, n. 2, 2007.

DUBUISSON-QUELLIER, S.; LAMINE, C. Faire le marché autrement. L'abonnement à un panier de fruits et de légumes comme forme d'engagement politique des consommateurs. Sciences de la société, v. 62, 2004.

DUFOING, F. Ellul, conscience critique de l’écologisme. Disponível em: <http://ecologieradicale.over-blog.com/article-ellul-consicnce-critique-de-l-ecologisme-premiere-partie67743886.html>. Acesso em: 20 jul. 2012.

DUPAS, G. (ED.). Meio ambiente e crescimento econômico : tensões estruturais. São Paulo: Editora UNESP : IEEI-Instituto de Estudos Econômicos e Internacionais, 2008.

DUVERGER, T. La décroissance, une idée pour demain. Paris: Sang de la terre, 2011. 
EKOVICH, F. S. La gauche et l'écologie. Quelle adaptation possible? In: LAZAC, M. (Ed.). La Gauche en Europe depuis 1945. Paris: PUF, 1996.

ELLUL, J. Histoire de la propagande. Paris: Presses Universitaires de France, 1967.

ELLUL, J. A técnica e o desafio do século. Rio de Janeiro: Paz e Terra, 1968.

ELLUL, J. L’illusion politique. Paris: Pluriel / Le Livre de Poche, 1977.

ELLUL, J. Changer de révolution. L’inéluctable prolétariat. Paris: Seuil, 1982a.

ELLUL, J. Jacques Ellul ou la passion d'un sceptique. Le Nouvel Observateur, 17 jul. 1982b.

FAUCHER, F. Manger vert: Choix alimentaires et identité politique chez les écologistes français et britanniques. Revue Française de Science Politique, v. 48, n. 3-4, 1998.

FERRY, L.; RENAUT, A. Pensamento 68. São Paulo: Editora Ensaio, 1988.

FILLIEULE, O. France. In: ROOTES, C. (Ed.). Environmental Protest in Wester Europe. New York: Oxford University Press, 2007.

First International Conference on Economic De-Growth for Ecological Sustainability and Social Equity. Proceedings of the First International Conference on Economic DeGrowth for Ecological Sustainability and Social Equity. Anais...Paris: Research \& Degrowth, 18 abr. 2008.

FLIPO, F. Voyage dans la galaxie décroissante. Mouvements, v. 2, n. 50, 2007.

FOSTER, J. B. Capitalism and Degrowth: An Impossibility Theorem. Monthly Review, v. 62, n. 8, 2011.

FUKUYAMA, F. Fim da historia e o ultimo homem. Rio de Janeiro: Rocco, 1992.

GEERTZ, C. A interpretação das culturas. Rio de Janeiro: LTC Editora, 1989.

GORZ. O socialismo difícil. In: O socialismo difícil. Rio de Janeiro: Zahar Editores, 1968a.

GORZ, A. Estratégia operária e neocapitalismo. Rio de Janeiro: Zahar Editores, 1968b.

GORZ, A. Écologie et politique. Paris: Éditions du Seuil, 1978.

GORZ, A. Marché, marchandise, rapports marchands. In: Capitalisme, socialisme, écologie. Paris: Galilée, 1991.

GORZ, A. Le travail dans la sortie du capitalisme. Alias "La sortie du capitalisme a déjà commencé”. EcoRev', v. 28, 2008. 2007.

GORZ, A. Carta a D. São Paulo: Annablume; Cosac Naify, 2008.

GRADIS, Y. Yvan Gradis ("Le Publiphobe”) : “Ma stratégie, c'est le supplice de la goutte”, 8 set. 2004. Disponível em:

$<$ http://www.lemonde.fr/economie/article/2004/09/08/yvan-gradis-le-publiphobe-mastrategie-c-est-le-supplice-de-la-goutte_378345_3234.html>. Acesso em: 30 abr. 2012

GRESH, A. Comment construire un autre monde? Actes du colloque. Anais... In: DÉFAIRE LE DÉVELOPPEMENT, REFAIRE LE MONDE. Paris: Le Monde Diplomatique; Unesco; Most; La Ligne d'Horizon, 2002.

GRINEVALD, J. Esperamos uma crise ecológica planetária, 10 set. 2005. Disponível em: $<<$ http://www.swissinfo.ch/por/capa/Esperamos_uma_crise_ecologica_planetaria.html? siteSect $=105 \&$ sid=6046015\&cKey=1126448395000\&ty=st $>$. $>$. Acesso em: 12 ago. 2006

HARDT, M.; NEGRI, A. Império. São Paulo: Editora Record, 2006.

HARVEY, D. Condição pós-moderna: uma pesquisa sobre as origens da mudança cultural. 22. ed. São Paulo: Ed. Loyola, 2012.

HENST, E. V. D. Intellectuels décroissants - La construction d'un espace intellectuel autour de la décroissance. Lille: Université Lille II - Faculté des sciences juridiques, 
politiques et sociales, 2007.

Historique du mot. Les cahiers de l'IEESDS, 2006.

HOBSBAWM, E. O marxismo hoje: um balanço aberto. In: HOBSBAWM, E. (Ed.). História do Marxismo. O marxismo hoje (Primeira Parte). Rio de Janeiro: Paz e Terra, 1991. V. 11.

HOPKINS, R. Manuel de transition: de la dépendance au pétrole à la résilience locale. Montréal: Écosociété, 2010.

HUGUES. Marche pour la décroissance - À Contre Courant. Disponível em: $<$ http://acc.agora.eu.org/Marche-pour-la-decroissance,814.html>. Acesso em: 9 maio. 2012.

ICTA; RESEARCH \& DEGROWTH; UNIVERSIDAD AUTONOMA DE BARCELONA. ECONOMIC DEGROWTH TODAY - Call for papers, dez. 2009.

ILLICH, I. A Igreja sem poder. In: Libertar o futuro. Lisboa: Publicações Dom Quixote, 1973a.

ILLICH, I. Eloquência do silêncio. In: Libertar o futuro. Lisboa: Publicações Dom Quixote, $1973 b$.

ILLICH, I. Pobreza planejada: o resultado final da assistência técnica. In: Libertar o futuro. Lisboa: Publicações Dom Quixote, 1973c.

ILLICH, I. Escola: a vaca sagrada. In: Libertar o futuro. Lisboa: Publicações Dom Quixote, 1973d.

ILLICH, I. A futilidade da escola. In: Libertar o futuro. Lisboa: Publicações Dom Quixote, 1973e.

ILLICH, I. Um apelo à celebração. In: Libertar o futuro. Lisboa: Publicações Dom Quixote, $1973 f$.

ILLICH, I. Energia e equidade. Lisboa: Livraria Sá da Costa Editora, 1975.

ILLICH, I. Hommage à Jacques Ellul. Écologie et politique, v. 11-12, 1994.

ILLICH, I. L’obsession de la santé parfaite. Disponível em: <http://www.mondediplomatique.fr/1999/03/ILLICH/11802>.

ILLICH, I. Le développement ou la corruption de l'harmonie en valeurActes du colloque. Anais... In: DÉFAIRE LE DÉVELOPPEMENT, REFAIRE LE MONDE. Paris: Le Monde Diplomatique; Unesco; Most; La Ligne d'Horizon, 2002.

ILLICH, I. La convivencialidad. In: Obras Reunidas. Mexico: FCE, 2006a. v. 1.

ILLICH, I. La expropriación de la salud. In: Obras Reunidas. Mexico: FCE, 2006b. v. 1.

ILLICH, I. Alternativas. In: Obras Reunidas. Mexico: FCE, 2006c. v. 1.

ILLICH, I. La sociedad desescolarizada. In: Obras Reunidas. Mexico: FCE, 2006d. v. 1.

INGRAND, J.-S. Bernard Charbonneau et Jacques Ellul: des critiques similaires de la grande ville, au nom de la libertéActes Colloque. Anais... In: BERNARD CHARBONNEAU: HABITER LA TERRE. Pau: Université de Pau et des Pays de l'Adour, 2012.

JACOB, J. Histoire de l'écologie politique. Paris: Editions Albin Michel, 1999.

JAMESON, F. Cultura e capital financeiro. In: A cultura do dinheiro : ensaios sobre a globalização. Petrópolis: Vozes, 2001.

KALLSCHEUER, O. Marxismo e teorias do conhecimento. In: HOBSBAWN, E. (Ed.). História do Marxismo. O marxismo hoje (Segunda Parte). Rio de Janeiro: Paz e Terra, 1989.

KEMPF, H. Sauver le monde par la décroissance soutenable! Le Monde, 21. 2002. 
KEUCHEYAN, R. Hémisphère gauche. Paris: Zones, 2010.

KITSCHELT, H. La gauche libertaire et les écologistes français. Revue française de science politique, v. 40, n. 3, 1990.

LACAN, J. O estádio do espelho como formador da função do Eu. In: ZIZEK, S. (Ed.). Um mapa da ideologia. Rio de Janeiro: Contraponto, 1996.

LAMAUD, I. Regards croisés sur la révolte écologiste: l'écosocialisme de Gorz et le sentiment de la nature chez CharbonneauActes Colloque. Anais... In: BERNARD CHARBONNEAU: HABITER LA TERRE. Pau: Université de Pau et des Pays de l'Adour, 2012.

LAMINE, C. Un mouvement social? v. 357, maio. 2008.

LATOUCHE, S. Le développement n'est pas un remède, c'est le problèmeActes du colloque. Anais... In: DÉFAIRE LE DEVELOPPEMENT, REFAIRE LE MONDE. Paris: Le Monde Diplomatique; Unesco; Most; La Ligne d’Horizon, 2002.

LATOUCHE, S. O Sul e o ordinário etnocentrismo do desenvolvimento. Le Monde Diplomatique Brasil, 1 nov. 2004.

LATOUCHE, S. Entretien de Serge Latouche, 2007.

LATOUCHE, S. Pequeno tratado do decrescimento sereno. São Paulo: WMF Martins Fontes, 2009.

LATOUR, B. Políticas da natureza. Bauru: EDUSC, 2004.

LAURENCIN, D. Préface. In: CHARBONNEAU, B. (Ed.). Finis Terrae. Lyon: À plus d'un titre, 2010.

L’ÉQUIPE DE LA REVUE SILENCE. Les multiples chemins de l'écologie. Silence, v. 400, abr. 2012.

LÉVI-STRAUSS, C. Introdução à obra de Marcel Mauss. In: MAUSS, M. (Ed.). Sociologia e Antropologia. São Paulo: Cosac Naify, 2003.

LÉVI-STRAUSS, C. O cru e o cozido (Mitológicas vol. 1). São Paulo: Cosac \& Naify, 2004.

LIMA, B. D. T. Vanguarda do Atraso ou Atraso da Vanguarda? Oswald de Andrade e os teimosos destinos do Brasil. São Paulo: Universidade de São Paulo, 2012.

LOPES, J. S. L. (ED.). A ambientalização dos conflitos sociais: participação e controle público da poluição industrial. Rio de: Relume-Dumará, 2004.

LOUREIRO, I. Herbert Marcuse - Anticapitalismo e Emancipação. Trans/Form/Ação, v. 28, n. 2, p. 7-20, 2005.

LOWY, M. Ecologia e socialismo. São Paulo: Cortez, 2005.

MARCUSE, H. Ideologia da sociedade industrial. Rio de Janeiro: Zahar Editores, 1969.

MARCUSE, H. Sobre o conceito de negação na dialética. In: Idéias sobre uma teoria crítica da sociedade. Rio de Janeiro: Zahar Editores, 1972.

MARCUSE, H. A esquerda sob a contra-revolução. In: Contra-revolução e revolta. Rio de Janeiro: Zahar Editores, 1973.

MARCUSE, H. A revolução pela repulsa - Entrevista com Herbert Marcuse. Plural, v. 14, 2007.

MARQUES, A. C.; COMEFORD, J. C.; CHAVES, C. Traições, intrigas, fofocas, vinganças: notas para uma abordagem etnográfica do conflito. In: MARQUES, A. C. (Ed.).

Conflitos, política e relações pessoais. Campinas: Pontes, 2007.

MARX, K. O Capital - vol. 1. Livro Primeiro. São Paulo: Abril Cultural, 1984a.

MARX, K. O Capital - vol. 3. Livro Terceiro. Tomo 1. São Paulo: Abril Cultural, 1984b.

MARX, K. O Capital - vol. 2 Livro Primeiro. São Paulo: Nova Cultural, 1985. 
MARX, K. O Capital - vol. 5. Livro Terceiro. Tomo 2. São Paulo: Nova Cultural, 1986.

MEADOWS, D. et al. Limites do Crescimento. São Paulo: Perspectiva, 1973.

MERKEL, W. Is there a crisis of democracy in Europe? How do the economic crisis and other social trends impact on the "European Model of Democracy". In: 8"

ENCONTRO ASSOCIAÇÃO BRASILEIRA DE CIÊNCIA POLÍTICA. Gramado, RD: 2012.

MYLONDO, B. (ED.). La décroissance économique pour la soutenabilité écologique et l’équité sociale. Bellecombe-en-Bauges: Croquant, 2009.

OLLITRAULT, S. De la caméra à la pétition-web : le répertoire médiatique des écologistes. Réseaux, v. 17, n. 98, p. 153-185, 1999.

OLLITRAULT, S. Les écologistes français, des experts en action. Revue Française de Science Politique, v. 51, n. 1-2, 2001.

OUTRAGE. Fiche Pratique no 8: Du pétrole et des idées. Outrage, 2010.

PARTI POUR LA DÉCROISSANCE. Motion adoptée à l'assemblée générale du 17 janvier 2009, 2009. Disponível em: <http://www.google.com/url? $\mathrm{sa}=\mathrm{t} \& \mathrm{rct}=\mathrm{j} \& \mathrm{q}=\&$ esrc $=\mathrm{s} \&$ source=web\&cd=1\&ved=0CFMQFjAA\&url=http $\% 3 \mathrm{~A} \% 2 \mathrm{~F}$ $\% 2$ Fwww.partipourladecroissance.net\%2Fwp-content\%2Fuploads \%2F2010\%2F03\%2FMotion-PPLD-17-janvier2009.pdf\&ei=yGsNUObqOIGE8ATL_dTYCg\&usg=AFQjCNEa2y0AFazrPkJMy7ehy5-g54EIA>. Acesso em: 14 jul. 2012.

PARTI POUR LA DÉCROISSANCE. Proposition de Génealogie de la Décroissance Politique en FranceParti Pour la Décroissance, 2012a. Disponível em: <http://www.partipourladecroissance.net/?page_id=4819>. Acesso em: 12 abr. 2012.

PARTI POUR LA DÉCROISSANCE. La saloperie que nous n'achêterons pasParti Pour la Décroissance, 2 jan. 2012b. Disponível em: <http://www.partipourladecroissance.net/? $\mathrm{p}=6720>$. Acesso em: 11 abr. 2012.

PEIXOTO, A. Pessoa, existência e fenomenologia: notas sobre as concepções do personalismo de Emmanuel Mounier. Revista de Filosofia Aurora, v. 22, 2010.

PONCET, M. Souscription. Disponível em: $<$ http://naturalistes69.free.fr/gazette29/expo_souscription.htm>. Acesso em: 24 abr. 2012.

PRENDIVILLE, B. L'Écologie, La Politique Autrement? Culture, Sociologie et Histoire des Ecologistes. Paris: L’Harmattan, 1993.

RAJAGOPAL. A dream of a new word orderActes du colloque. Anais... In: DÉFAIRE LE DÉVELOPPEMENT, REFAIRE LE MONDE. Paris: Le Monde Diplomatique; Unesco; Most; La Ligne d'Horizon, 2002.

REBELLYON. Retour sur 2 ans de lutte à Lyon contre l'extrême-droite et ses agressionsRebellyon, 1 abr. 2011a. Disponível em: <http://rebellyon.info/Retour-sur-2ans-de-lutte-a-Lyon.html> . Acesso em: 25 abr. 2012.

REBELLYON. Ne laissons pas Lyon devenir un laboratoire de l'extrêmedroiteRebellyon, 9 maio. 2011b. Disponível em: <http://rebellyon.info/Ne-laissonspas-Lyon-devenir-un.html>. Acesso em: 25 abr. 2012.

REVUE SILENCE. L'écologie en 600 dates. [S.l.] Le Passager Clandestin, 2012.

RIBEILL, G. Aspects du développement du réseau ferré français sur la longue durée.

L’approche historique. Cahier / Groupe Réseaux, v. 1, n. 1, p. 10-25, 1985.

ROBERT, J.; BORREMANS, V. Prefacio. In: ILLICH, I. (Ed.). Obras Reunidas. Mexico: 
FCE, 2006. v. 1.

ROBERT, J.; PAQUOT, T. Monument ou chantier? L’héritage intellectuel d'Ivan Illich (19262002). Esprit, n. agosto, setembro, 2010.

RODES, M. Bernard Charbonneau: quel militantisme entre réflextions théoriques et pratiques de terrain? Actes Colloque. Anais... In: BERNARD CHARBONNEAU: HABITER LA TERRE. Pau: Université de Pau et des Pays de l'Adour, 2012.

ROUSSELLIER, N. Des Vertes de toutes les couleurs. Histoire et sociologie du mouvement écolo. Vingtième Siècle. Revue d'histoire., v. 37, n. 1, 1993.

SAFATLE, V. Cinismo e falência da crítica. São Paulo: Boitempo Editorial, 2008.

SAFATLE, V. A esquerda que não teme dizer seu nome. São Paulo: Três estrelas, 2012.

SANTOS, B. DE S. Comentários a "Energia e Equidade”. In: ILLICH, I. (Ed.). Energia e equidade. Lisboa: Livraria Sá da Costa Editora, 1975.

SAWICKI, F.; SIMÉANT, J. Inventário da sociologia do engajamento militante: Nota crítica sobre algumas tendências recentes dos trabalhos franceses. Sociologias, v. 13, n. 28, dez. 2011.

SCHNEIDER, F. Welcome!Conference Program - 2nd Conference on Economic Degrowth. Anais... In: SECONDE CONFERENCE ON ECONOMIC DEGROWTH FOR ECOLOGICAL SUSTAINABILITY AND SOCIAL EQUITY. Barcelona: 26 mar. 2010

SCHWARZ, R. As ideias fora do lugar. In: Ao vencedor as batatas. São Paulo: Duas Cidades, 2008.

SEKULOVA, F.; RIJNHOUT, L. Convite para Conferência de Barcelona, 18 nov. 2009.

SILENCE. Aux lectrices et lecteurs. Silence, v. 331, p. 2, jan. 2006.

STOLLE, D.; HOOGHE, M.; MICHELETTI, M. Politics in the Supermarket: Political Consumerism as a Form of Political Participation. International Political Science Review, v. 26, n. 3, p. 245-269, 2005.

SZCZPANSKI-HUILLERY, M.; SIMON-EKOVICH, F. Mouvement écologiste et revues intellectuelles. In: AGRIKOLIANSKY, É.; SOMMIER, I. (Eds.). Radiographie du mouvement altermondialiste. Paris: La Dispute, 2005.

TAVOLARO, S. B. DE F. Movimento ambientalista e modernidade: sociabilidade, risco e moral. São Paulo: Annablume / Fapesp, 2001.

THOELE, A. Decrescer para viver. Disponível em: $<$ http://www.swissinfo.ch/por/Capa//Decrescer_para_viver.html?cid=859716>. Acesso em: 12 abr. 2012.

THOUVENIN, B.; DELESTRÉ, C. Pour des démarches participatives d’habitat. Silence, v. 372, out. 2009a.

THOUVENIN, B.; DELESTRÉ, C. Un exemple au Danemark Andelssamfundet. Silence, v. 372, out. 2009b.

TILLY, C. Social movements, 1768-2004. Boulder: Paradigm Publishers, 2004.

TRAORÉ, A. Sauver l'Afrique du développementActes du colloque. Anais... In: DÉFAIRE DE DEVELOPPEMENT, REFAIRE LE MONDE. Paris: Le Monde Diplomatique; Unesco; Most; La Ligne d'Horizon, 2002.

TROUDE-CHASTENET, P. L'écologiste. Disponível em: <http://www.jacquesellul.org/jacques-ellul/portraits/lecologiste>. Acesso em: 14 jul. 2012.

TROUDE-CHASTENET, P. Itinéraire. Disponível em: <http://www.jacquesellul.org/jacques-ellul/portraits/itineraire>. Acesso em: 14 jul. 2012.

VÉLORUTION. Vélorution. Disponível em: <http://agendalyon.org/2012-02-25/v 
\%C3\%A9lorution>. Acesso em: 25 abr. 2012.

VIOLA, E. A multidimensionalidade da globalização, as novas forças sociais transnacionais e seu impacto na política ambiental do Brasil, 1989-1995. In: FERREIRA, L. DA C.; VIOLA, E. (Eds.). Incertezas da sustentabilidade na globalização. São Paulo: Hucitec, 1996.

VIVEIROS DE CASTRO, E. Perspectivismo e multinaturalismo na América indígena. In: A inconstância da alma selvagem. São Paulo: Cosac Naify, 2002a. .

VIVEIROS DE CASTRO, E. O conceito de sociedade em antropologia. In: A inconstância da alma selvagem. São Paulo: Cosac Naify, 2002b.

VIVEIROS DE CASTRO, E. Temos que criar um outro conceito de criação. In: SZTUTMAN, R. (Ed.). Eduardo Viveiros de Castro. Rio de Janeiro: Beco do Azougue Editorial, 2008.

VIVEIROS DE CASTRO, E. Desenvolvimento econômico e reenvolvimento cosmopolítico: da necessidade extensiva à suficiência intensiva. Sopro, v. 51, 2011.

ZHOURI, A.; LASCHEFSKI, K. (EDS.). Desenvolvimento e conflitos ambientais. Belo Horizonte: Editora UFMG, 2010.

ZIN, J. Qu'est-ce que l'écologie-politique? Écologie et Politique, v. 40, p. 41-49, 2010.

ZIZEK, S. O espectro da ideologia. In: ZIZEK, S. (Ed.). Um mapa da ideologia. Rio de Janeiro: Contraponto, 1996a.

ZIZEK, S. Como Marx inventou o sintoma. In: ZIZEK, S. (Ed.). Um mapa da ideologia. Rio de Janeiro: Contraponto, 1996b.

Sites

http://friche-rvi.org

http://www.3ptitspois.fr

http://www.agendalyon.org

http://www.decroissance.org

http://www.delautrecotedelarue.net

http://www.delautrecotedupont.fr

http://www.degrowth.org

http://www.entropia-la-reuve.org

http://www.ladecroissance.net

http://www.lescompostiers.org

http://www.letrefle-nehna.fr/

http://www.objecteursdecroissance.fr/

http://www.rebellyon.info

http://www.revuesilence.net 